

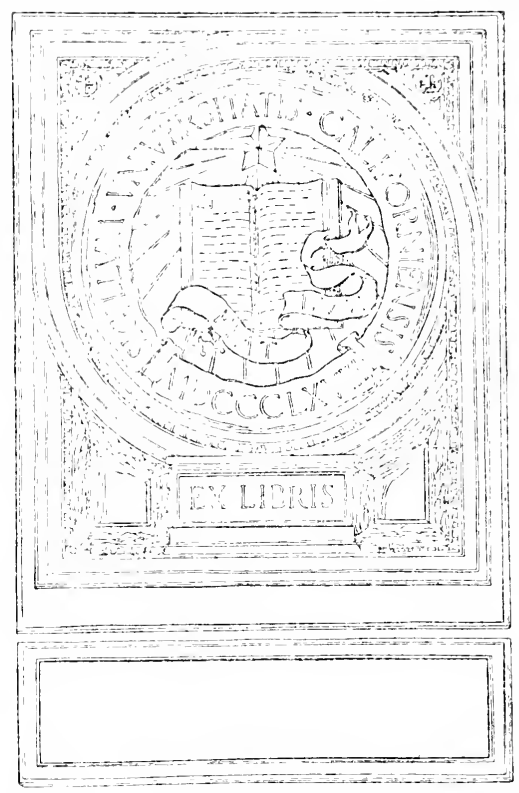


Sind in 

A LSACE-LORRAINE 


\section{INTERNATIONAL LAW AND}

\section{THE GREAT WAR}

By Coleman Phillipson, M.A., Ll.D., LiTT.D., Barrister-at-Law. With an Introduction by Sir John Macdonell, ..C. B., LL.D. Cloth, 15/- net.

"A valuable review by a leading authority both of the flagrant infractions of international law which have marked the present war, and of the changes caused by new conditions of war and industry which must inevitably take place in international law."-The Times.

"The whole book is a monument of lucidity and fairness."-Evening Standard.

\section{TERMINATION OF WAR AND} TREATIES OF PEACE

By Coleman Phillipson, M.A., LL.D.,

Lit T. D., Barrister-at-Law. Cloth, 21 /-net.

"No systematic and comprehensive treatise on this subject, it would seem, at present exists; and, now that it is becoming one of urgent practical importance, the student and the man of affairs alike portance, the student and the man of affairs alike
will welcome its full discussion by a leading autbority on international law."-The Times.

" Dr. Phillipson's work, which is a 'comparative and analytical study,' distinguished by its completeness, learning, and lucidity, is not only of great scientific interest for the lawyer, but of prac. tical value for the diplomatist."- The Nation.

T. FISHER UNWIN, LD., LONDON 



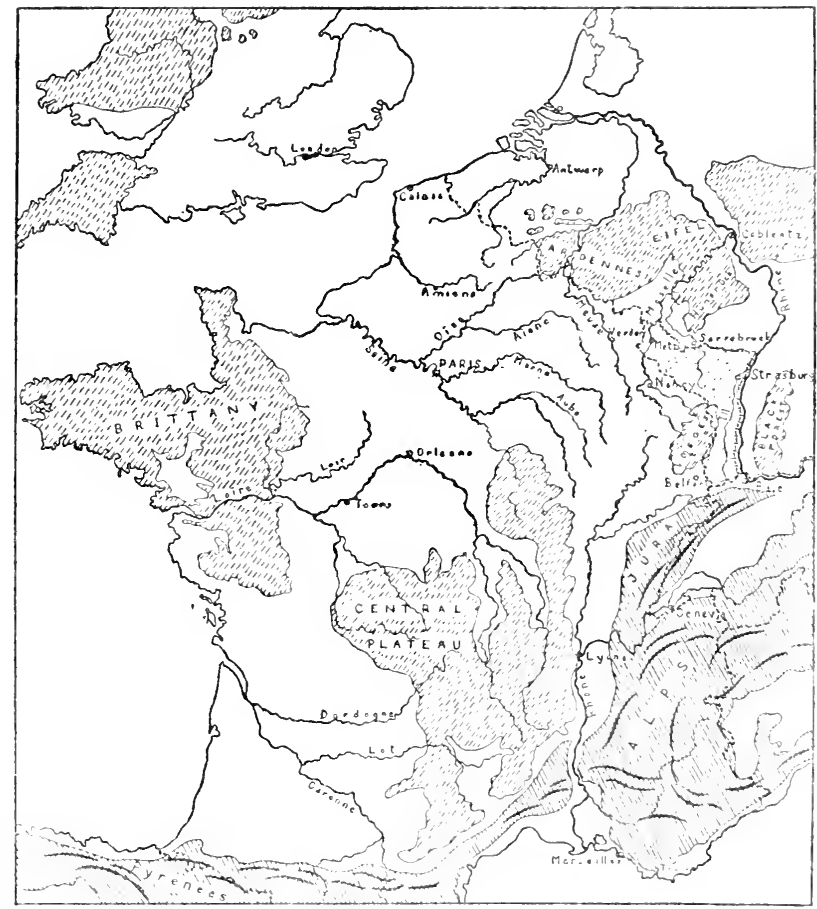

Structural Map of France showing Boundaries in 1870 and in 1914

The young folded mountains (Pyrenees, Alps) are indicated by one type of shading, the plateau regions, built up of old, hard rocks, by another. The unshaded areas are regions of unfolded, younger rocks, whose dip is for the most part slight. The area aunexed by Germany from France in 1871 is dotted lightly. (In part after Barre.) 


\title{
ALSACE-LORRAINE
} PAST, PRESENT, AND FUTURE

\author{
BY \\ COLEMAN PHILLIPSON \\ M.A., LL.D., LITT.D. \\ OF THE INNER TEMPLE, BARRISTER-AT-LAW
}

WITH FOUR MAPS

LONDON: T. FISHER UNWIN, LTD.

ADELPHI TERRACE 
First published in 1918

(ALI RIGHTS RESERVED) 
DEDICATED

To

THE KIGHT HON. SIR FREDERICK SMITH, BART. K.C., M.P.

HIS MAJESTY'S ATTORNEY.GENERAI. 



\section{P R E F A CE}

THE object of the present work is to consider the problem of Alsace-Lorraine-how it arose in the past, what its present aspects are, and what appears to be its most desirable solution for the future.

To carry out this object I have adopted the following plan. First the salient features of the question are indicated; then follow a description of the provinces and of their economic position, and a brief historical outline the purpose of which is to help us to look at the entire problem dispassionately, and in due perspective, in view of the various contending claims advanced. Next I deal with the annexation in I87I, the fateful Franco-German negotiations, the regulation of numerous matters arising out of the transfer of the territory, the German view of the acquisition, the proposals made as to the status of the acquired provinces, and how their germanisation was to be effected. This is followed by an account of the solemn and moving protests of I87I; and a critical analysis of the German claims to AlsaceLorraine, and the alleged grounds of annexationhistorical association, nationality and race, language, necessity (political, economic, and military), conquest and confirmation thereof by the Treaty of Frankfort. Here are examined, too, the common assertions that the latter treaty was necessarily abrogated on the commencement of hostilities in I9I4, and that the forcible acquisition of the provinces by France would 
be only a restoration, and not a conquest. Then I set forth the German régime in Alsace-Lorraine from I87 I down to the outbreak of the Great War, the methods adopted to bring about the entwelschung of the Reichsland, and the factors retarding such a consummation; the strivings and aspirations of the Alsace-Lorrainers, the rise and growth of the nationalist movement, the views and feelings in France, the revanche ideal, its obsolescence, and recent recrudescence. Finally, I consider the numerous solutions that have from time to time been suggested or demanded (as the case may be), e.g. reannexation to France, the establishment of Alsace-Lorraine as an autonomous State within the framework of the German Empire, the creation of an independent neutralised State, partition schemes, and readjustments of boundaries ; also the Franco-German coal and iron problem, and the question of a plebiscite. I point out the difficulties and advantages of the various proposals, and show which is the best in the interests of justice and international peace and amity.

In the investigation of all these matters I have done my utmost on the one hand to be concise and clear, and on the other to preserve throughout an attitude -if I may say so - of judicial impartiality. " Tribuere suum cuique" : it is ever the wisest policy to follow this principle, even if it involves giving the devil his due.

Coleman Phillipson.

4. Elm Court, Temple, April I3, 1918. 


\section{CONTENTS}

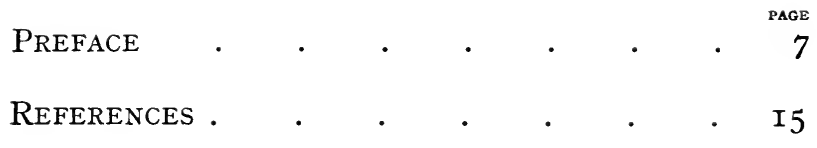

\section{CHAPTER I}

\section{INTRODUCTORY: THE QUESTION OF ALSACE-LORRAINE STATED}

Alsace-Lorraine long a bone of contention-Forcible annexation in $1871-$ How the question of Alsace-Lorraine has arisen-How it differs from the Near Eastern Question-Other States concerned-Different aspects of the question-German view that there is no question of AlsaceLorraine-Relation to the present war-The " challenge-cup of Europe" -Desiderata in the solution of the question-Difficulties involved in the solution-Justice and right the fundamental consideration

pp. 19-33

\section{CHAPTER II}

\section{DESCRIPTION OF ALSACE-LORRAINE, AND ITS ECONOMIC POSITION}

Area and configuration-Minerals; climate; population-Characteristics of the people-Language-Religion-Industries-Agriculture-Exports and imports-Transport and communication; public works-BudgetPublic instruction-Great progress under German rule . pp. 34-48 


\section{CHAPTER III}

\section{HISTORICAL OUTLINE}

Roman occupation-Germanic invasions-Union with the German Empire.

(a) Lorraine: Middle Ages-Relations with France-Certain annexations to France-The Three Bishoprics-Cession to France. (b) Alsace : Middle Ages-Part of Germany till the seventeenth century-The Thirty Years War-Treaty of Westphalia (1648)-Position of StrassburgThe French Revolution; Union with France . • . . pp. 49-60

\section{CHAPTER IV}

\section{ANNEXATION OF ALSACE-LORRAINE IN IS7I}

(a) Military events leading to peace negotiations: Outbreak of the war of $1870-N e u t r a l i t y$ of the Powers-German successes-Annexation proclaimed-Capitulation of Metz-Siege of Paris-National Assembly at Bordeaux; peace signed. (b) Negotiations and Arrangements as to Alsace-Lorraine: Protests against announced annexation-Bismarck's fear of European intervention-He secures Russian support-His doubt as to territorial demands; military view-Demands made at Versailles -German resolve as to annexation-Bismarck's concession-The Pre. liminaries of Versailles-Negotiations at Brussels-Difficulties of the French plenipotentiaries-Negotiations transferred to Frankfort-The French plenipotentiaries-Treaty of Frankfort-Belfort-Germans affect to be disappointed-The boundary commission-Rights of inhabitants of ceded territory-Regulation of various other matters

pp. $61-85$

\section{CHAPTER V}

PROPOSALS AS TO THE FATE OF ALSACE-LORRAINE AFTER ITS CONQUEST-BISMARCK'S VIEW OF THE TASK OF ASSIMILATION

Protests in Germany against the annexation-German policy as to the annexed territory-View as to neutralisation-View as to plebisciteDivision of the territory suggested-Autonomy suggested-AlsaceLorraine made a Reichsland-Bismarck's view as to German assimilation-IIis doubts about Metz . . . . . . pp. 86-97 


\section{CHAPTER VI}

\section{THE PROTESTS OF I87I AGAINST THE ANNEXATION}

Declaration of Alsace-Lorraine deputies-Submitted to the National Assembly-Various other protests-Debates in the Assembly on the proposed cession-Vote on the Preliminaries-Further protest of AlsaceLorraine deputies-Demand from Germany-Effects of the annexation

pp. 98-I I I

\section{CHAPTER VII}

GERMAN CLAIMS TO ALSACE-LORRAINE - ALLEGED GROUNDS OF ANNEXATION: (a) HISTORICAL GROUNDS; NATIONALITY AND RACE; LANGUAGE

Historical grounds: Ranke's view-Mommsen's view-Treitschke's viewEarly treaties-Appeal to the Holy Roman Empire-Difficulties in such contentions. Racial grounds: Names as a criterion-Claim untenable-Treitschke's arrogant pretensions. Claim on ground of language : Early struggles between languages-German dialect becomes predominant-Position of the pays messin. Principle of nationalityAttachment of Alsace to France-Principle of public right

Pp. I I - I 3 I

\section{CHAPTER VIII}

\section{GERMAN CLAIMS TO ALSACE-LORRAINE - ALLEGED GROUNDS OF ANNEXATION : (b) NECESSITY; CONQUEST AS CONFIRMED BY THE TREATY OF FRANKFORT}

Claim on ground of necessity. Economic necessity: Outlet for overcrowded Germany ? - Natural deficiencies of Germany. Political necessity : German unity and the Reichsland. Military necessity: Frontier security-Mommsen on Metz. Conquest as confirmed by the Treaty of Frankfort: Prussia's territorial ambitions-Bismarck's admission in 1862-German views as to "right of conquest "-Recent growth of opinion as to conquest-Ground of illegitimacy of conquest-When conquest justified-International law as it existed in $187 \mathbf{I}$. Binding force of Treaty of Frankfort-Supersession of one treaty by another 


\section{CHAPTER IX}

\section{GERMAN RÉGIME IN ALSACE-LORRAINE}

Military occupation, 1870-71-Status from February 1871 to June $1871-$ Dictatorship, I871-3-The imperial constitution applied, 1874Territorial Delegacy established, 1874-Council of State established, I879-Application of the régime-Repressive measures-New constitution, 19r - Why autonomy refused-Precautions of Germany on outbreak of the present war-Why thorough germanisation not effected -The German official classes-The German immigrants-Pan-germanism-German methods compared with French . . pp. 155-183

\section{CHAPTER X}

\section{VIEWS AND ASPIRATIONS OF ALSACE-LORRAINE--THE} NATIONALIST MOVEMENT

Protest of the Alsace-Lorraine deputies in the Reichstag, 1874 -Why autonomist movement began-Aim in social and intellectual life of the people-Method of the nationalist leaders-Differentiation between autonomists and protesters-Socialist party; anti-clerical campaignDemocrats leave the Catholic party-National Union formed, 1910; its programme-Manifesto against the Constitution of IgII-" Home rule" demanded, I913-Before present war, memory of I87I fading in Alsace-Lorraine-Did Alsace-Lorraine desire reunion with France? -Noisseville affair; Saverne affair-Attitude of the people towards France and Germany-Distinctive personality of Alsace-LorraineThe new generation and France-Doubtful indications as to feelings and desires of the people-Attitude of Alsace-Lorrainers at outbreak of the war-Declarations of the two Chambers, 19I7-Conclusions

pp. I $\&_{4}-2$ I 3

\section{CHAPTER XI}

\section{VIEWS AND FEELINGS IN FRANCE AS TO ALSACE-LORRAINE}

Three phases of French feeling-Revanche ideal-Evanescence of ren vanche ideal: contributory causes-Pacific policy of Frencis democracy - Why revanche ideas were passing away-Disturbing currents in France since $187 \mathrm{I}-$ France and the question of nationalities-Recent national policy of France--Von Bülow's vicw of the French temperFrench views after outbreak of the war-British view- Why France determined to recover Alsace-Lorraine-Whether recovery would be "restoration" or conquest-Status of Alsace-Lorrainers in France during the war . . . . . . . . Pp.2I4-234 


\section{CHAPTER XII}

\section{SOLUTIONS SUGGESTED : (a) REANNEXATION TO FRANCE}

Reannexation followed by referendum suggested-German pronouncements as to Alsace-Lorraine - Forcible reannexation not a true solution; inherent difficulty-Various other difficulties: Frontier-Grouping of Alsace-Lorraine within political framework of France-The language question-The legal system-The industrial organisation-The commercial system-Fiscal legislation-The religious question-The educational system-Position of immigrants and the younger generationThe previous nationalist movement-Other difficulties. Interregnum suggested for smoothing over difficulties . . . . pp. 235-250

\section{CHAPTER XIII}

\section{REANNEXATION AND THE FRANCO-GERMAN COAL AND IRON PROBLEM}

Commercial basis of the war-German declarations in 1915 as to economic needs-Coal and iron in modern war-German need of coal and iron - German demands as to Briey and Longwy-Coal resources of France and Germany-Iron ore in Lorraine-Iron resources of GermanyEffect of depriving Germany of the Lorraine ore . . pp. 251-264

\section{CHAPTER XIV}

\section{SOLUTIONS SUGGESTED: (b) AUTONOMY WITHIN THE GERMAN EMPIRE}

The nationalist ideal-Alsace-Lorraine can no longer remain a Reichsland - German view in I898-Swiss view-French views-Recent German opinion-German Socialist view, 1917-Form of autonomous government-Position of Alsace-Lorraine as an autonomous State-Autonomy followed by plebiscite suggested . . . . . pp. 263-270

\section{CHAPTER XV}

\section{SOLUTIONS SUGGESTED: (c) ALSACE-LORRAINE AS AN} INDEPENDENT STATE

Proposed neutralisation-Suggested in $\mathrm{IS}_{7} \mathrm{O}-$-German objections-Population to be consulted-Resolution of League of Peace, IS84-Form of independent government-Various matters for adjustment-Advantages of creating an independent Alsace-Lorraine: Meeting the wishes of 
the people-Revanche obviated-Fusion of Germanic and Gallic elements-Military service difficulties removed-Bond of union between France and Germany-Would be a "bulfer" State. Future international co-operation and treaties . . . . pp. $27^{\mathrm{I}-284}$

\section{CHAPTER XVI}

\section{SOLUTIONS SUGGESTED: (d) PARTITION; ALTERATION OF BOUNDARIES, ETC.}

Partition proposals-Language as a basis-Suggested union of Alsace with Baden-Division among German States-Frontier rearrangementThe pays messin to France and the rest neutralised-Alsace-Lorraine as part of a Rhenish-Alpine Confederation-Boundary readjustmentArbitration of the Pope suggested-Difficulties in these proposals: Division on basis of speech-Division on basis of sentiment-Division between German States-Lorraine as an independent State-Suggested confederation. The Rhine as a Franco-German boundary-Criticism of the view as to a Rhine frontier-Desideratum in fixing frontiers

pp. $28_{5-301}$

\section{CHAPTER XVII}

\section{THE QUESTION OF A PLEBISCITE}

Plebiscite for Alsace-Lorraine necessary-Examples of plebiscites-Cases of annexation without a plebiscite-Anglo-American practice-Juristic opinion-Grounds of support of plebiscite-Grounds of objection to plebiscite-Each case to be considered on its merits-Alsace-Lorraine a suitable case-Prevailing views as to self-determination of peoplesAlsace-Lorraine desirous to decide its own fate-Alsace-Lorraine ever against war as a solution-Opposition to plebiscite by France, Germany, and leading Alsatians-Criticism of objections-A real difficulty: presence of immigrants and absence of emigrants-Compromise necessary-Organisation of plebiscite-Persons who should vote-Probable result-Essential condition for the future . . . . pp. 302-318

$\operatorname{INDEX} \cdot \quad \cdot \quad \cdot \quad \cdot \quad \cdot \quad \cdot \quad \cdot \quad \cdot \quad \cdot 3^{19-328}$

\section{I.IST OF MAPS ${ }^{1}$}

Structural Map of France showing Boundaries in 1870 and $191_{4} 4$ Frontispiece Sketch-map of Alsace and Eastern Lorraine. . . . . . . 35 Geological Sketch-map of Alsace-Lorraine . . . . . . $\quad$. 253 The Ramparts of Paris . . . . . . . . . . 299

1 For the use of these maps indebtedness is acknowledged to the Royal Scottish Geographical Society, and to Miss M. I. Newbigin, the editor of its magazine. 


\section{REFERENCES}

M. Alfassa, "Le fer et le charbon lorrains" (Paris, I9I6).

Count von Beust, "Aus drei Viertel Jahrhunderten" (Stuttgart, I887).

K. Blind, "Alsace-Lorraine and William II (with personal recollections)" ; in Fortnightly Review, vol. 78 (Ig02), pp. 257 seq.

J. C. Bluntschli, "Das moderne Völkerrecht" (Nördlingen, I872). French trans. by C. Lardy, "Le Droit international codifié" (Paris, I895).

J. E. C. Bodley, "The Church in France" (London, I906). "France" ; in Encyclopadia Britannica, vol. x. (I9Io).

G. Bourdon, "L'Énigme allemande” (Paris, I9I3). Eng. trans. (London, I9I4).

E. Bourgeois, "The Third French Republic" ; in Cambridge Modern History, vol. xii. (Igro), chap. v.

Prinz von Bülow, “Imperial Germany." Eng. trans. (London, I9I6).

M. Busch, "Bismarck: Some secret pages of his history." Eng. trans. 3 vols. (London, I898).

A. J. Butler (Trans.), "Bismarck: the man and the statesman" (London, I898).

C. Calvo, "Le droit international théorique et pratique." 6 vols. $5^{\text {th }}$ ed. (Paris, I8g6).

R. de Card, "Les annexions et les plébiscites dans l'histoire contemporaine" ; in Études de droit international (Paris, I89o).

E. J. Dillon, "Counting the cost"; in Fortnightly Review, September I9I7.

F. Y. Eccles, "Alsace-Lorraine" (Oxford Pamphlets, I9I4-I5).

A. Eckel, "La réunion de l'Alsace et de la Lorraine à la France" (Vesoul, I894).

F. Engerand, "Les frontières lorraines et la force allemande" (Paris, I9I6). 
J. Favre, "Le Gouvernement de la Défense Nationale." 3 vols. (Paris, I87I-5).

P. Fiore, "Nouveau droit international public." Traduit de l'italien par C. Antoine. 3 vols. (I a ris, IE\& $\sigma_{1}$ ).

Florent-Matter, "L'Alsace de nos jours" (Paris, Igo8).

N. Fustel de Coulanges, " L'Alsace, est-elle allemande ou française? Réponse à M. Mommsen" (Paris, I870).

H. Galli, "Gambetta et l'Alsace-Lorraine" (Paris, I9II).

C. Gavard, "Un diplomate à Londres: Lettres et Notes, I87I-I877" (Paris, I895).

A. Haenel, "Deutsches Staatsrecht" (I892, etc.).

G. Hanotaux, "Contemporary France." Eng. trans. 4 vols. (London, I903).

J. Heimweh, "Droit de conquête et plébiscite” (Paris, I896). " La guerre et la frontière du Rhin" (Paris, I895). "Triple Alliance et Alsace-Lorraine" (Paris, I892).

P. A. Helmer, "Alsace under German rule" (London, I9I5).

___ "France-Alsace" (Paris, Igr6).

Sir T. M. Holdich, " New political boundaries in Europe: AlsaceLorraine" ; in New Europe, February 8, I9I7. " Political frontiers and boundary-making" (London, I9I6).

F. von Holtzendorff-Vietmansdorf, " Encyclopädie der Rechtswissenschaft.” Ed. J. Kohler. 5 vols. (München; Leipzig, I9I3-I4).

B. E. Howard, "Alsace-Lorraine in its relation to the German Empire" ; in Political Science Quarterly (New York, I9o6), vol. xxi.

D. S. Jordan, "Alsace-Lorraine: a study in conquest ; I9I3" (Indianopolis, I9I7).

F. Klein, "L'Évêque de Metz: Vie de Mgr. Dupont des Loges" (Paris, I899).

P. Laband, "Das Staatsrecht des Deutschen Reiches." 3 vols. (Freiburg i. B., I876-82.)

G. de Lamberty, “ Mémoires pour servir à l'histoire du XVIII' siècle," etc. If vols. (Amsterdam, I734-40).

A. Lasson, "Das Culturideal und der Krieg" (Berlin, I868). " Princip und Zukunft des Völkerrechts" (Berlin, IS7I).

L. de Launay, " Le problème franco-allemand du fer" ; in Revue des Deux Mondes, July I5, I9I6.

A. Laussedat, "La délimitation de la frontière franco-allemande" (Paris, IgoI). 
H. et A. Lichtenberger, "La question d'Alsace-Lorraine" (Paris, I9I5).

J. Longuet, "Alsace-Lorraine" ; in The Nation, January 5 and I2, I9r8.

O. Lorenz, "Kaiser Wilhelm und die Begründung des Reichs, I866-I87I" (Jena, I902).

L. W. Lyde, "Some frontiers of to-morrow" (London, I915).

M. Maass, "Was soll mit Elsass-Lothringen werden" (Leipzig, I884).

G. May, "Le Traité de Francfort" (Paris, I909).

"La lutte pour le français en Lorraine avant I870." Annales de l'Est publiées par la Faculté des Lettres de l'Université de Nancy (Paris: Nancy, I9I2).

E. Milhaud, "La démocratie socialiste allemande" (Paris, I903).

T. Mommsen, "Letters on the war between France and Germany." Eng. trans. (London, I87I).

G. Monod, "Allemands et français" (Paris, I892).

F. Naumann, "Central Europe." Eng. trans. (London, I9I6).

M. I. Newbigin, "The Problem of Alsace-Lorraine"; in The Scottish Geographical Magazine, March and April, I9I8 (vol. xxxiv.).

J. Novicow, “ L'Alsace-Lorraine: Obstacle à l'expansion allemande" (Paris, I9I3).

F. A. Ogg, "The Governments of Europe" (New York, I9r3).

H. Oncken, "The German Empire" ; in Cambridge Modern History, vol. xii., chap. vi. (Cambridge, I9ro).

Général Palat, "L'alliance franco-allemande ou la guerre " (Paris, I9r4).

“Patiens,” “ L'Alsace-Lorraine devant l'Europe” (Paris, I894).

C. Pfister, "La limite de la langue française et de la langue allemande en Alsace-Lorraine" (Paris, I890).

C. Phillipson, "Termination of war and treaties of peace" (London, I9I6).

C. Phillipson and N. Buxton, "The question of the Bosphorus and Dardanelles" (London, I9r7).

G. Rasch, "Die Preussen in Elsass und Lothringen" (Braunschweig, I874). French trans. (Paris, I876).

M. Sembat, "Faites un roi, sinon faites la paix" (Paris, I9r3).

H. von Treitschke, "Was fordern wir von Frankreich" (Berlin, I870). Eng. trans. in "Germany, France, Russia, and Islam " (London, I9I5). 
J. Valfrey, “Histoire du traité de Francfort et de la libération du territoire français" (Paris, I874).

Villefort, " Recueil des traités, conventions, lois, décrets et autres actes relatifs à la paix avec l'Allemagne." 5 vols. (Paris, I $872-9)$.

A. Wagner, "Elsass und Lothringen und ihre Wiedergewinnung für Deutschland” (Leipzig, I870).

H. Welschinger, "Bismarck" (Paris, I9oo). "La guerre de 1870 . Causes et responsabilités" (Paris, I9I0).

“ La protestation de l'Alsace-Lorraine les I 7 février et $I^{\text {er }}$ mars I 87 I à Bordeaux" (Paris, I9I4).

L'Abbé E. Wetterlé, “Ce qu'était l'Alsace-Lorraine et ce qu'elle sera" (Paris, I9I5).

S. Whitman (Ed.), "Conversations with Prince Bismarck." Collected by $\mathrm{H}$. von Poschinger (London; New York, I9o0).

J. Zeller, "Origines de l'Allemagne et de l'Empire Germanique " (Paris, I872).

“Die Bevölkerung Elsass-Lothringens” (Strasburg, I908).

"La neutralité de l'Alsace-Lorraine." Compte rendu de l'Assemblée générale des membres de la Ligue internationale de la paix et de la liberté. Tenue à Genève le 7 sept. 1884 (Bâle, I884).

“Parliamentary Papers," vol. 70 (1870). 


\title{
ALSACE-LORRAINE
}

\author{
CHAPTER I
}

\section{INTRODUCTORY: THE QUESTION OF ALSACE-LORRAINE STATED}

Alsace-Lorraine long a bone of contention-Forcible annexation in $1871-$ How the question of Alsace-Lorraine has arisen-How it differs from the Near Eastern Question-Other States concerned-Different aspects of the question-German view that there is no question of AlsaceLorraine-Relation to the present war-The " challenge-cup of Europe" -Desiderata in the solution of the question-Difficulties involved in the solution-Justice and right the fundamental consideration.

From very early times Alsace-Lorraine was a bone of contention between rival races and rival sovereigns. In the numerous conflicts of the contending Alsaceparties, the lands and possessions of these Lorraine unhappy provinces were repeatedly subjected $\begin{array}{r}\text { long a } \\ \text { bone of }\end{array}$ to destruction or pillage, and the population contention. to all the violence of warfare, with the inevitable result that the social, intellectual, and industrial development of the country-rich as it is in natural resources and favoured in its geographical position and configuration-has been seriously hampered. Thanks to such salient features and barriers as the Rhine on the one hand and the Vosges Mountains on the other, the Alsace-Lorraine territory has constituted a border-country separating ever hostile and seemingly incompatible peoples; and its extent and 
boundaries have frequently changed with the vicissitudes of war and the succession of its rulers.

At one time it extended in the north to the sea; at another time it stretched in the east to the Rhine; sometimes, again, it comprised in the west Varying areas and towns now forming an integral
areas. part of France. At certain periods it was divided up into a duchy, counties, and free towns; and its earlier history-when it possessed neither a distinctive name nor a clearly defined area-is to be found, not in indigenous records, but in the chronicles of various foreign countries, such as France and Germany, Flanders and Burgundy. In later times it witnessed the increasing and fateful rivalry of the French and the Germanic races, and the sanguinary struggles between them, resulting in the annexation of its territory in $187 \mathrm{I}$ to Germany.

Now this annexation was a forcible one; it was a consequence of German victories in the field, and of Forcible a signal military humiliation on the part of annexation the French; and it was effected without in $187 \mathrm{r}$. consulting the inhabitants of the conquered territory. The latter-a progressive, cultured, and a traditionally freedom-loving people-repeatedly protested against their violent dissociation from France; and the great majority of them being unable to abandon their homes and property and so remain French, in pursuance of the right of option conceded to them, were compelled against their will and against their instincts and aspirations to assume German nationality and submit to the new, trying, uncongenial, oppressive régime of German domination, which inflicted all the burdens of subjecthood, but withheld many of the most important rights and privileges of citizenship. 
Moreover, so far as France was concerned, she was obliged to submit to the annexation, and her consent thereto, formally recorded in the Preliminaries of Versailles and the Treaty of Frankfort, was given involuntarily-it was extracted from her by reason of superior physical force ; and

How the question of AlsaceLorraine has arisen. so she has thenceforth felt that the arrangement made in I87I was not, and could not be, a definitive solution, and she has long hoped for an opportunity of recovering the conquered territories, and of fulfilling the vows of revanche. On the other hand, Germany has repeatedly declared that she is prepared to shed the last drop of her blood rather than relinquish the provinces; and she lays claim to them on various grounds (which will be examined later). Thus has arisen another sinister stumbling-block for Europe-the question of Alsace-Lorraine.

In a previous publication ${ }^{2}$ it was pointed out that one of the most important and most urgent questions of modern European politics is that of the Difference Straits of the Bosphorus and Dardanelles; between that this constitutes the fundamental basis of the Near Eastern Question-a problem which for several generations Europe has endeavoured to solve by " all the arts of Question. diplomacy, all the devices of political combinations, and all the violence of wars" ; that this unsolved question has produced, with ever-increasing intensity, the dangerous misunderstanding and ill-feeling due to tortuous diplomacy, international jealousy and friction, unhealthy rivalry; and that numerous devastating wars have inevitably resulted therefrom. The difference between the Near Eastern Question

1 The Question of the Bosphorus and Dardanelles. By Coleman Phillipson and Noel Buxton. (London, 1917.) 
and the Alsace-Lorraine Question (which may be termed the Western Question) lies in the fact that the former involves directly and intrinsically the conflicting interests of the Great Powers of Europe and their incompatibility, not only amongst themselves, but with a non-Christian Empire, whose régime, government, and institutions are entirely out of harmony with those of the rest of Europe, and are a serious obstacle to the development and application of European public law and to the promotion of international relationships conformably to such law. On the other hand, the Alsace-Lorraine Question is, in itself, less comprehensive in its scope and purport, and involves primarily, if not exclusively, first, the conflicting interests between two powerful neighbouring States, so different in civilisation, culture, and ideals, and secondly-this being the particularly distinctive differentia - the claims of a clearly defined territory with a population sharing in some of the characteristics of the rival nations, but clearly difiering from both in regard to many other important qualities.

But, owing to the geographical solidarity of Europe and to the political and economic nexus of its nationsother States indeed of the nations of the world generally concerned. - the question unavoidably affects countries other than those immediately concerned. It is therefore nowadays well-nigh impossible to "localise" a conflict between two countries, and confine its results to the contending parties; their conflict becomes indirectly a conflict also with third parties, who thus acquire the right to have a say in the matter. Moreover, the principal disputants, fearing the growing power of each other, seek, in pursuance of a precarious and factitious diplomatic policy, to ally themselves with other Powers, in order to secure sympathy and 
material support in the event of an outbreak of hostilities. Thus the quarrel primarily between two States drags in other States, which necessarily become parties thereto. Thus with the object of maintaining the existing equilibrium threatened by the military preparations and accumulation of armaments by this or that Power, combinations are brought about, and are virtually transformed into armed camps, which are a hindrance to the social and commercial development of nations, and to the realisation of an enlightened domestic policy. All this has happened as a result of the Franco-German hostility consequent on the annexation of the two French provinces in I87I; and so not only States in their collective and representative capacity, but also citizens and subjects in their individual capacity have been, and are, affected by this territorial conquest. The masses of the populations of the world have ever been obliged to pay their blood and treasure as the price for the misguided aims and overweening ambitions of fanatical cliques and inflammatory sections of their fellowcitizens. It comes to pass, therefore, that each one of us is indirectly concerned in, because each is prejudicially affected by, such a political blunder as the seizure of Alsace-Lorraine by Germany, which has engendered a veritable European nightmare. As a recent Russian writer observes: “. . . La question de l'Alsace-Lorraine influe directement sur le train ordinaire de notre vie quotidienne par l'impôt du sang et l'impôt de l'argent." 1

The question of Alsace-Lorraine, which arose in I87I and has subsisted to this day, has not always possessed the same character and presented the same

1 J. Novicow, L'Alsace-Lorraine: Obstacle a l'expansion allemande (Paris, I913), p. 4. 
aspects; nor has it always been maintained in the same acute form, and regarded as involving the Different same implications. At the time of the aspects of annexation of the provinces, the question the question. was easier to understand and to appreciate; here was a conqueror, there was a defeated country at the mercy of the victor, who exacted the abandonment of a large slice of territory, the inhabitants of which repeatedly protested against the violent dissociation from their mother-country. The question, then, in the eyes of France, appertained to what she regarded as an illegitimate act of conquest, especially so when consummated without regard to the wishes of the local population. Nêutral statesmen, such as Gladstone,' also felt that the predominating factor of the compulsory cession was not the alleged right of conquest on the part of Germany, or the inalienable right of property on the part of France, but the attachment of the population of the wrested provinces to France and their refusal to change their nationality and to be dragged into an alien civilisation. In the eyes of Germany, on the other hand, no AlsaceLorraine question ever came into being; for she held that she was entitled, in virtue of her military victories, to gain possession of the territory, which she claimed to be necessary for her security, and that such possession was specifically recognised and definitively sanctified by the Preliminaries of Versailles and the Treaty of Frankfort-solemn treaties between the contending parties, who contemplated and expressly stipulated their perpetual validity. Accordingly, the majority of people now look upon the question as one that merely relates to a clearly

1 Lord Morley, Life of William Ewart Gladstone (London, 1903). 3 vols. ; vol. 1i. p. 347. 
defined province, which once belonged to Germany, was afterwards taken from her by France, was reannexed by Germany in $\mathrm{I} 87 \mathrm{I}$, and is now claimed again by France. The issue, however, is not so simple ; for, as we shall see in the subsequent chapters, in the interval between I87I and, say, I9I4, various important changes have taken place, first, in regard to the attitude of France, secondly, in the attitude of Germany, thirdly, in the aspirations and tendencies of the Alsace-Lorrainers, and in the development of their country, and lastly, in the economic and industrial evolution of modern Europe-all of which changes cannot but have affected the situation as it existed in $187 \mathrm{I}$ and in the few years immediately following, as well as the original contentions of the principal parties concerned, together with the claims of other States. Now, again, since the outbreak of the Great War in August I9I4, further changes have been introduced, notably in regard to the claims of France and the view of her principal ally, Great Britain; also in the offer of a new policy on the part of Germany towards Alsace-Lorraine, hitherto constituted as a Reichsland (imperial territory). All these considerations must be carefully taken into account in order to gain a clear conception of this Western question as it exists to-day, and as it has existed for two generations.

Whenever the question of Alsace-Lorraine has been raised since $187 \mathrm{I}$, the Germans-not only their Conservative and Pan-Germanist parties, but also the more liberal sections of the people have emphatically and indignantly de- question of -have emphatically and indignantly de- question of clared that there was no such question at Lorraine. all. Thus, such a philosophical and anti-militarist writer as Professor Paulsen observed in I907 that the 
question of the annexed provinces cannot constitute a subject of discussion between France and Germany. ${ }^{1}$ Germans have repeatedly asserted that the final annexation in I87I, confirmed by solemn treaties, made future transactions on the subject impossible. On the contrary, Frenchmen have reiterated the claim that there is and has been all along a question French reply of Alsace-Lorraine, by reason of the violent thereto. dismemberment in $187 \mathrm{I}$, the repeated protests of France and the annexed population, the oppression of the Alsace-Lorrainers under German domination, and the imprescriptible right of peoples to dispose of their own destiny. The latter point has recently been emphasised in the manifesto of the French Socialist party (December I9I5). Europe, too, has in general recognised the existence of the question, and has realised that the failure to effect a settlement satisfactory to all parties is fraught with serious dangers menacing the public peace. This being so, it must necessarily be concluded that the question of Alsace-Lorraine, despite the profuse German disclaimers, must also exist for Germany, whether she likes it or not. Indeed, to maintain that there was no question of Alsace-Lorraine after the conclusion of the definitive Treaty of Frankfort, May Io, I87 I, is either "insolent arrogance or myopia." " In point of fact, Germany was not insensible of its existence. We may recall that when the Hague Conference of I899 entered on the discussion of a general treaty of arbitration, fears were aroused in Germany as to whether her adhesion to such a convention would necessitate her submitting the Alsace-Lorraine question to an international tribunal. Again, the German Emperor, realising the tension and strained relation-

1 La paix par le droit (February 1907). 2 Novicow, op. cit., p. 43. 
ships with France owing to this very question, emphasised at a dinner at Berlin, January 2, I908, that the German people must remain united in view of an approaching conflict. An attitude of this kind shows a recognition of the existence of the questionat all events, in the sense that in France at least the transaction of I87I was not and could not be regarded as final and closed.

In these circumstances, admitting the existence of the question of Alsace-Lorraine, can it be said that it was the cause of the present war? Was the Here we have to discriminate between the question of direct and immediate causes of the war, Larraine the and the indirect and more distant causes.presentwar? We may say that it was not the direct and immediate cause of the war, inasmuch as before the outbreak of hostilities the relations between France and Germany were peaceable and normal, and the incidents that gave rise to the conflict between Austria and Serbia did not particularly concern France. But the moment France felt compelled to commence hostilities against Germany, the question of AlsaceLorraine, which before was relegated to the margin of consciousness in French minds, was rapidly transferred to the focus of consciousness, and its solution, implying a reversal of the act of I87I, became an essential object of France's war. France did not, then, take up arms for the purpose of regaining possession of the lost provinces; but as soon as she entered the war it was felt that her former territories constituted an important part of the stakes.

Looking at the events from a broader point of view, it may be said with truth and accuracy that the question of Alsace-Lorraine was a proximate cause of the war, seeing that its origin lies in the forcible 
1. annexation of French territory and the humiliation inflicted on a great and proud country which could As a not for several generations entirely forget

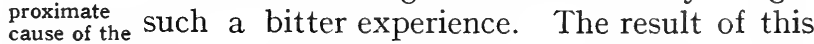
presentwar. was the establishment of political combinations in Europe, mutually distrustful and suspicious, highly susceptible in case of the smallest friction, ready to take offence and respond with threats at the first emergency. Thus European politics was ever in a state of tension, and it needed but a spark to set ablaze the whole dangerous structure resting on such an unstable foundation. And the main cause of this condition of European politics was, at bottom, the irreconcilable character of the relationships between France and Germany, rendering impossible a friendly alliance and frank entente between them.

Another contributory cause is itself a result of Germany's victory in I870-7I, and her annexation

\section{German} of Alsace-Lorraine-viz. her territorial lust territorial and aggressiveness, and her assumption
lust and lugtensive- of an arrogant hegemony on the Continent. ness. This aggressiveness has been condemned even in Germany. Thus Herr Walther Schücking, professor of international law at the University of Marburg, writing in I908, said that nowhere can one see more clearly than in German conduct in Alsace how disastrous for the German popular mind the influence of Bismarck has been in certain respects. Though it seems impious to say so, the writer observes, yet it must be said. Bismarck was a genius from the point of view of action, but not from the point of view of thought. The German watchword should be "less Bismarck and more Schiller." Germany ought to shake off her aggressive nationalism, which 
is contrary to her true genius.' In this sense, then, the question of Alsace-Lorraine was the virtual cause of the war. As Dr. Fried, a distinguished German pacifist, remarked recently in a Swiss paper : : "Alsace-Lorraine is, after all, the cause of the war. The fight for the two provinces had determined European politics, during the past half-century, culminating in the present war." Similarly, Mr. Asquith observed at Liverpool, October II, I9I7: "It is this act of crude and short-sighted spoliation which was the root and source of the unrest, of the unstable equilibrium, of the competition in armaments, which have afflicted Europe during the life-time of two generations, and which have culminated in the most terrible war in history." "3 At all events, whether Alsace-Lorraine is the cause of the present war or not, there is no doubt that the failure to reach an agreement on the question during the course of the hostilities was the main reason for continuing this widespread and sanguinary conflict. Thus, Baron von Kühlmann, the German Foreign Secretary, said in the Reichstag, October 9, I9I7: "After a very thorough investigation of the whole situation, according to information derived from most diverse sources, I am convinced that the great question around which the struggle of the nations centres, and for which they are shedding their blood, is not, in the first instance, the Belgian question. The question for which Europe is being turned more and more into a heap of ruins is the question of the future of Alsace-Lorraine."

Having regard to such considerations and to the fact that secular contests have centred round Alsace-

1 Friedenswarte, February 1908; cited by Novicow, op. cit., p. $37^{8}$.

2 Neue Zürcher Zeitung (a Swiss independent paper), June 24, 1917.

${ }^{3}$ Daily Chronicle, October 12, 1917. 
Lorraine, those provinces have sometimes been described-not, however, without an appearance of The "chal- flippancy-as " the challenge-cup of Europe." lenge-cup "Were it not for the destruction and deof Europe." vastation, the waste of treasure and loss of lives that these contests have brought with them, the phrase might well be admitted as being aptly descriptive of the part played by these unhappy provinces. Sometimes Belgium, sometimes the Balkan peninsula has been designated the cockpit of Europe. This designation may just as appropriately be applied to Alsace-Lorraine. Romans, Gauls, Huns, Germans, French, Austrians, Hungarians, Spaniards, Swedes, have fought on the blood-soaked soil of this small country. The old Chronicles of Thann relate how the land was devastated in the Thirty Years War. In the seventeenth century Alsace was a great battlefield of religion. The battles of the Franco-German war of $1870-7$ I were fought principally in Lorraine. And now, once again, a conflict-the greatest of all -rages in these provinces, where the destiny of many a nation will probably be decided.

Whatever settlement is eventually arrived at, it must realise at least two desiderata: first, it must Desiderata take account of the principle of nationality in the solu- which concerns mainly Alsace-Lorraine, to-

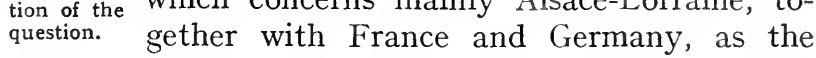
great protagonists struggling, the one to regain her "lost children," the other to retain what she conceives to be now an integral part of herself; secondly, it must establish and assure Franco-German peace and friendship, as the vital condition indispensable for securing the real pacification of Europe, and indeed of the world. So long as Alsatian disaffection continues, the resentment of France and her nurture 
of revanche ideas will remain. So long as FrancoGerman concealed or manifest hostility continues, the crushing burden of European armament, military expenditure, and bleeding of the populations, will subsist, and industry and commerce, social reform and education, will suffer an incalculable injury. If these suggested desiderata are realised, then AlsaceLorraine may well serve as a conciliatory connectinglink, as a felicitous bond of union between the long hostile French and German peoples. As M. Léon Boll, the editor of the Strassburg Journal d'AlsaceLorraine, said not long before the outbreak of the present war: "Let us make of Alsace-Lorraine the melting-pot in which shall be blended the doubledistilled civilisation of Germanism and Latinism." '

To arrive at a solution satisfactory to all parties is now all the more difficult inasmuch as economic considerations at present play a predominating part. Formerly the importance of possess- involved in ing Alsace-Lorraine was conceived to depend primarily on the exigencies of military strategy and territorial security. Now the mineral wealth and the fertile soil of the Reichsland, coupled with its advantageous position-in the very midst of a great net-work of communications radiating in every direction-are thought to be the main factors that stimulate the desire of the contending parties to possess it. The Pan-Germanists are fully convinced that to be deprived of the provinces would be tantamount to destroying the fondly cherished ideal of securing the economic and political domination of the Continent. Similarly, France, now less mindful than formerly of the strategic significance of the provinces, less

1 G. Bourdon, L'Énigme allemande (Paris, 1913). English translation (London, 1914); French edition, P. 4r7; English edition, p. 316. 
susceptible also to the old vows of revanche (at least, apart from their recent resuscitation during the present war), attaches all the greater importance to the economic side of the question; she feels that the unrestricted possession of the natural resources of the provinces would contribute substantially to her commercial and industrial development, and to her national power and welfare. Nevertheless, it is now thought in some quarters that it is not the actual economic value of the provinces that intensifies the difficulty of the question, but the fact that their possession is now considered by the leading belligerents as symbolising the issue of the war; that is to say, that whoever keeps them will be accounted the victor. Thus, Dr. Fried, writing in June I9I7, points out that, having regard to the intrinsic value of the disputed territory, common sense would suggest that the prize sought is not worth the struggle; since the enormous losses in life, property, and treasure suffered by each of the contending parties already exceed on the one hand the total value of the provinces, and on the other the total number of their inhabitants; so that the actual value of the object aimed at is no longer the main consideration. "The fight for these few square miles has now assumed the terrible meaning that their final possession at the end of the war is regarded as the certificate of victory ... even if the so-called victor is only another loser." " Outside France and Germany, it is felt generally that European equilibrium and peace are jeopardised so long as France is far outstripped by Germany in material property, and-as a corollary-in the growth of population, and therefore in national power and fighting strength; and that the possession of these

1 Neure Zürcher Zeitung, June 24, 1917. 
rich provinces has contributed considerably to bringing about this difference.

All these difficulties and conflicting interests, then, must be adjusted in the ultimate settlement of the question. And, finally, the moral principle Justice the of international justice, which in the eyes fundamental of many takes precedence of strategic and economic interests, must be vindicated therein, so as to recognise the dominion of public morality and public law over the society of nations, and the subordination of might to right. For when one contemplates the question of Alsace-Lorraine as impartially and dispassionately as possible, one cannot help coming to the conclusion that to do justice to these disputed provinces and to their aggrieved people is far more important than to satisfy the economic and military demands of Germany or France, or to make amends for the humiliation of IS7I by facilitating the consummation of an oscillating or adventitious revanche.

Having thus set forth the essential significance of, and the various implications involved in, the question before us, we have now to inquire into the diverse relevant matters for the purpose of grasping the real issue and arriving at what seems to be the best solution. 


\section{CHAPTER II}

\section{DESCRIPTION OF ALSACE-LORRAINE, AND ITS ECONOMIC POSITION}

Area and configuration-Minerals; climate; population-Characteristics of the people-Language-Religion-Industries-Agriculture-Exports and imports-Transport and communication; public works-BudgetPublic instruction-Great progress under German rule.

ALSACE-LORRAINE is bounded on the south by Switzerland ; on the east by Baden, from which it is separated by the Rhine; on the north and north-east by the Bavarian Palatinate, the Prussian Rhine Province, and Luxemburg; on the west by France.

The area of the provinces as ceded in $187 \mathrm{I}$ is 5,605 square miles, that is less than one-tenth of the area

Area of Alsaceof England and Wales, or a little less than Lorraine. the area of Yorkshire. The total area acquired by Germany constituted nearly the whole of the former Alsace, together with about one-fifth of the former Lorraine; the annexed area of Alsace alone being 3,344 square miles. The maximum length of Alsace-Lorraine from north to south is I45 miles, the maximum breadth from east to west is I05 miles, and the minimum breadth, at the line drawn through Schlettstadt, is 24 miles.

The configuration of the country is varied and beautiful. ${ }^{1}$ There are mountains and hills, valleys,

1 As to the surface and soils of Alsace-Lorraine, see an article by Miss M. I. Newbigin, in The Scottish Geographical Magazine, vol. xxxiv (1918), pp. I2I seq. 

rivers, plains, tablelands, lakes, forests; the hills being well wooded with fir, beech, and oak. The salient physical features may be divided roughly configurainto three classes: mountain land, plain, tion. and plateau. First, the mountain land occupies the western half of Alsace, and consists of the Vosges range, which runs in a northerly direction from the gap or pass of Belfort (trouée de Belfort). A conspicuous peak of the Vosges is the Ballon d'Alsace, 4,085 feet high. Secondly, between the Vosges range and its sharp eastern slopes and the Rhine lies a plain of remarkable fertility occupying the eastern portion of Alsace. Thirdly, in the north-west there is a great undulating plateau, which descends gradually in the west to the valley of the Moselle, and is nearly co-extensive with Lorraine. From the Vosges chain beautiful valleys descend into the plain, each watered by its own stream, and all of them draining into the Ill-the only river of importance; the latter falls into the Rhine near Strassburg after a course of more than Ioo miles, and is navigable below Colmar. Among the smaller streams may be mentioned the Doller, the Thur, the Lauch, the Fecht, the Weisse, the Lieprette, the Bruche, and the Zorn.

The provinces possess not only a rich soil-one of the most fertile in central Europe-bit also great mineral wealth: coal, iron, copper,

Minerals. lead, potash, petroleum, rock-salt, silver.

The climate is temperate, the temperature varying according to altitude. The mean annual temperature of Strassburg is $49^{\circ} 8^{\circ} \mathrm{F}$., of Metz, $48^{\circ} 2^{\circ} \mathrm{F}$. The rainfall at Strassburg is $26 \frac{1}{4}$ in., Metz, Climate. $27 \frac{1}{2}$ in. (The mean annual temperature of London is $504^{\circ}$, and the rainfall from $20 \frac{1}{2}$ to $27 \frac{1}{2}$ in.)

The population of Alsace-Lorraine was, in 1877 , 
I,548,900; in I9r2, I,886,800; in I9I4, about Population. $x, 900,000$. The changes and fluctuations in the total number, due to the emigration of natives and the immigration of Germans, will be considered in a subsequent chapter.

The native Alsatians are neither French nor German in character, temperament, and ideals; they are Characteris- Alsatians, sharing certain characteristics of tics of the the rival nations, and differing markedly people. from both in many other qualities. There is more friction between the Germans and the Alsatians than between the Germans and the Lorrainers; the latter being for the most part engaged in mines, iron-works, and factories, and being mainly concerned with questions of industry and capital. The Alsatians are an optimistic, merry, religious, industrious people, lacking in enthusiasm generally, but with democratic and republican leanings. They are very practicallyminded, and set great store by material well-being. In the eyes of many Germans they have something of the Sancho Panza type in them. The Alsatian peasantry do not regard with favour the ubiquitous dispensations of paternalism; neither they nor the agricultural workers of Lorraine are deeply concerned with the broad questions of politics; both classes alike would desire the burdens of taxation to diminish, and, above all, they would like to be let alone to jog along in their own quiet, cheerful, simple manner. ${ }^{1}$

Both French and German are spoken by the educated Language. classes in the towns. Apart from these, the dialect. In some of the Vosges valleys French pre-

1 As to the feelings and aspirations of the people, see further infra, chap. $\mathbf{x}$. 
dominates or is spoken as the mother-tongue by a considerable proportion of the inhabitants. Along the Moselle French yields to German; similarly on the banks of the Sarre and in the environs of the confluence of the two rivers Nied. In I890 it was calculated that the French-speaking inhabitants of Alsace numbered 53,000; whilst there were I,000,000 who spoke German or a Germanic patois. ${ }^{1}$ French is the mother-tongue of a small portion of annexed Lorraine, notably in Metz and district (the pays messin). The Teutonic dialect of the north-east of Lorraine is somewhat like that of Luxemburg. Some of the recent census returns" (December I, I905) may be given as examples to show the linguistic diversity. In the district of Sarrebourg there were, in Saint-Quirin, 798 French, $22 \mathrm{I}$ German; in Abreschwiller, 887 French, 627 German; Lorquin, 6ro French, I49 German; Heming, 3I6 French, 209 German. In the district of Château-Salins, there were in the canton of Dieuze 7,062 French, 4,657 German; Vic, 6,362 French, 8oI German; ChâteauSalins, 8,868 French, I,32I German; Delme, 7,970 French, 574 German; Albestroff, I,83I French, 6,92I German.

It is to be noted that, after I87I, German became the official language of the country, and had to be used exclusively in all official assemblies, such as general councils, the Alsace-Lorraine Delegacy (the Landesausschuss), etc. ; and from January I, I888, its use was made obligatory in all courts of law.

1 Cf. C. Pfister, La limite de la langue française et de la langue allemande en Alsace-Lorraine (Paris, I89o), p. I4.

${ }^{2}$ Published by the official statistical bureau: Die Bevōlkerung ElsassLothringens (Strassburg, 1908); cited by G. May, La lutte pour le français en Lorraine avant I870. A unales de l'Est publiées par la Faculté des Lettres de l'Université de Nancy (Paris: Nancy, I912), p. 21. 
Moreover, the teaching of French in schools was considerably reduced. ${ }^{1}$

About three-quarters of the population of AlsaceLorraine are Roman Catholics. Thus, according to Religion. the returns of I904, there were I,3I0,39I Roman Catholics, 372,078 Protestants, and 32,370 Jews. In I905, out of a total civilian population of I,733,455, there were I,348,648 Roman Catholics, amounting to 78 per cent. Lorraine is proportionately more Roman Catholic than Alsace. In Alsace-Lorraine, unlike France, there is no separation between Church and State. Since I87I it has remained under the régime of the French Concordat ${ }^{2}$ concluded between Napoleon, as First Consul, and the Pope, July I5, I80I, whereby Roman Catholicism was allowed to be practised freely and publicly in France, subject to such regulations as the French Government might consider necessary to make in the interest of public order. The First Consul was empowered to nominate the bishops, and the Pope to confer canonical institution; whilst the bishops acquired the right of presentation to parochial cures, subject to the approval of the Government. Within certain limits Catholics were entitled to establish ecclesiastical endowments. The Concordat was supplemented by the Organic Articles (April 8, I802), which dealt with the jurisdiction of the Holy See, ecclesiastical discipline, areas of provinces, dioceses, and parishes, liturgy, catechism, dogma, and salaries. ${ }^{3}$ The professors in the seminaries were obliged to subscribe to the Gallican Declaration made in 1682 by the

1 The question of language, race, etc., is dealt with more fully, infra, chap. vii.

${ }^{2}$ As to the Concordat of rSor, see J. E. C. Bodley, The Church in France (London, 1906), pp. 30 seq., 35 seq.

3 Ibid., p. 4 I. 
French clergy, and to teach its doctrine. Sunday was proclaimed the official day of rest. ${ }^{1}$ Special laws have improved the position of ministers of religion, and the founding of various religious associations has been sanctioned. Elementary schools have retained their confessional character; religious instruction is given by the teachers, and the Catholic clergy have the right of inspection, and the right to sit on the local council (the Ortsschulvorstand), which controls public education. In other schools, religious teaching is obligatory and is given by the clergy. The ecclesiastical budget amounted in I9Io to about 5,000,000 marks, from which Protestant ministers, as well as Catholic, were paid. The influence of the State on the Lutheran Church is greater than on the Catholic Church, inasmuch as the Government of AlsaceLorraine nominates the president of the " Directoire" and the "Conservatoire," which are the two highest authorities of the Lutheran Church.

According to a recent estimate ${ }^{2}$ the occupations of the people are apportioned as follows: Occupations.

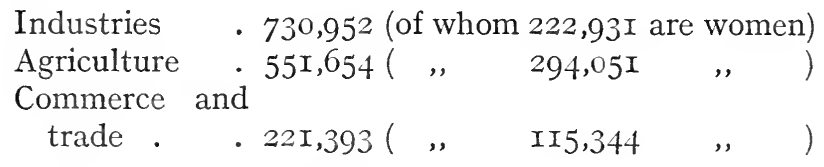

The principal industries are spinning and weaving. Textile goods (cotton, linen, woollen)-the amount produced in Alsace-Lorraine alone being Industries. equal to a quarter of the total produced in the whole of France-are manufactured at Mülhausen (the Manchester of Alsace) and Colmar, together with

1 J. E. C. Bodley, op. cit., p. 42 .

2 L'abbé E. Wetterlé, Ce qu'était l'Alsace-Lorraine et ce qu'elle sera (Paris, I9I 5), pp. 227 seq. 
Münster, Logelbach, Winzenheim, Türkheim, as well as in all the valleys of the Vosges; $\mathcal{c . g}$. in the valley of the Doller (Massevaux and other villages), of the Thur (Wesserling, St. Amarin, Thann, Moosch, Cernay, Willer), of the Lauch (Guebviller and adjacent villages), of the Lieprette (Ste. Marie-aux-Mines and adjacent districts). Other industries are dyeing; tanning and leather goods manufacture (Strassburg; and Massevaux in the Doller Valley); the manufacture of silk, lace, machinery, glass, china ware (in Lorraine), house furniture, clocks, paper, and tobacco (at Strassburg).

Further, mining and metallurgy employ a large number of people, the principal minerals being coal, iron (in Lorraine), potash, petroleum, and argentiferous lead. The question of coal and iron will be considered later separately ${ }^{1}$; for the present it will sufice to state that in I9I2, the coal extracted amounted to $3,538,95 \mathrm{I}$ tonnes ( $\mathrm{I}$ tonne $=\cdot 9842$ ton), of the value of $39,000,000$ marks; and in I9I3 (the last normal year) the iron mines of annexed Lorraine produced 2 I,I35,000 tonnes of ore, ${ }^{2}$ of the value of nearly 56,000,000 marks.

In 1872 the total yield of coal and iron from the Alsace-Lorraine mines was $\mathrm{I}, 000,000$ tonnes; so that in a period of forty years under the German régime the output has become twenty-five times as large. In I872 some I,500 workmen were employed in the furnaces, and turned out 200,000 tonnes of pig-iron; in I9Io there were 6,500 workmen, who produced 2,700,000 tonnes of pig-iron $(3,800,000$ in I9I3). The production of steel increased as follows: in I872, I80,000 tonnes; in I9IO, I,300,000 tonnes;

${ }^{1}$ See chap. xiii.

2 Comité des Forges de France. Circulaire No. 655, p. 13; quoted by M. Alfassa, Le fer et le charbon lorrains (Paris, 1916). 
in I9I3, 2,300,000 tonnes. ${ }^{1}$ With regard to potash, we may refer to a statement made in the spring of I9I6 by the Rhenish Westphalian Gazette, which is subsidised by Krupp's: "In Upper Alsace there are rich deposits of potash. If this region belonged to France, the German world-monopoly of potash, which lays the foreigner and especially the United States under tribute to this country, would be lost, and France would gain a notable source of wealth and also the means of providing her munitions. She would then control a powerful weapon in waging war against us. So important indeed are these potash deposits in munition-making that Germany has had to limit and control their export." The value of this mine is calculated at several thousand millions of francs. As to petroleum, the same paper says: "We have at Pechelbronn in Alsace the only large petroleum well in Germany, especially since the field of the Hanover Wietze district has greatly diminished. Thanks to Pechelbronn, Alsace has during the present war considerably assisted our economic resistance by supplying us with petroleum, benzine, and lubricating oils."

Agriculture is in a prosperous condition. The system of small holdings, favoured by the Civil Code, is established ; of cultivated land of $88 \mathrm{I}, 56 \mathrm{~g}$ hectares ( $\mathrm{I}$ acre $=\cdot 405$ hectare), there are Agriculture. 244,988 holdings. The slopes of the Vosges are covered with extensive and fruitful vineyards; in the neighbourhood of Colmar one of the best wines is produced. Recently viticulture has undergone an enormous development. The average production of wine is 600,000 hectolitres (I hectolitre $=22^{\circ}$. I gallons),

1 Cf. H. and A. Lichtenberger, La Question d'Alsace-Lorraine (Paris, I915), pp. IOI seq. 
of the value of about 22,000,000 marks; this amount constitutes a third of the total production of wine in Germany. The annual production of beer reaches I,274,000 hectolitres, and that of alcohol I4,857 hectolitres. ${ }^{1}$ Amongst the more important agricultural products may be mentioned wheat, barley, rye, oats; pulse ; potatoes ; tobacco ; hops; hemp, flax; beet (for sugar); dairy produce, notably cheese; fruit; timber. Forestry employs many people ; the forest land is extensive, nearly one-third of which belongs to the State, more than one-third to the communes, and the rest to private owners. The provinces are rich in horses, cattle, sheep, pigs, goats, hares, geese, ducks, and chickens.

As for the exports and imports of Alsace-Lorraine, we find that Germany takes by far the most important place. Thus in Ige9 the provinces exported imports. I0,248,604 tons of merchandise, of which 80 per cent. went to Germany; and of the imports, too, about 80 per cent. came from Germany. The remaining 20 per cent., both of exports and imports, was divided between Belgium, France, and Switzerland; that is, Belgium (and not France) came next to Germany.

The means of transport and communication have developed enormously under German organisation. Transport Watercourses-canals and rivers, especially and com- the Rhine-have been greatly improved; munication. the traffic of the port of Strassburg has increased considerably. In IS72 there were 768 kilometres of railway lines, and 9,000 employees. There are now over 2,000 kilometres of railways, which are valued at about a milliard francs $(t, 40,000,000)$, and which carried in I909 47,000,000 passengers and

1 Wetterlé, loc. cit. 
2,6II,000,000 kilometric tonnes of goods '; and the number of persons employed in I900 was $3 \mathrm{r}, 000$. The gross receipts for I9I2 amounted to I40,000,000 marks. The railway system was bought in I87I by France from the Eastern Company for 325,000,000 francs, and was ceded to Germany in reduction of the war indemnity. The postal, telegraphic, and telephonic services have also been rapidly extended in recent years. In I87I there were only I92 post offices, 57 telegraph offices, and 600 employees; whilst in I909 there were I,560 post offices, I,329 telegraph offices, and I,295 telephone offices, employing 8,000 persons, and despatching 44I,000,000 letters and packets, 13,000,000 parcels, and 2,000,000 telegrams. ${ }^{2}$

The establishment of public works for purposes of irrigation, canalisation, etc., has added Public largely to the value of the plant of the works. country, and on which a sum of about 48,000,000 marks was spent between I87I and I904.

The expenditure of the State in the provinces amounted in $I 872$ to $3 I, 000,000$ marks, in I880 to $47,000,000$ marks, and in I9I2 to $76,000,000$ marks; that is, it has increased, during the

Budget. forty years of German administration, from 20 marks per head of the population to 38 marks per head. The expenditure of the communes has in this interval grown in greater proportion-from I4,500,000 marks to $55,500,000$ marks, that is, from 9 marks per head to 29 marks per head. Similarly, the debt of the State has increased from 3,000,000 marks to $44,500,000$ marks (that is, from $2 \cdot 44 \mathrm{~m}$. per head to $22 \mathrm{~m}$. per head), and that of the communes from $15,000,000$

$1 \mathrm{H}$. and A. Lichtenberger, La Question d'Alsace-Lorraine, p. 98.

2 Ibid., p. 99. 
marks to $180,000,000$ marks (that is, from about Io $\mathrm{m}$. per head to $96 \mathrm{~m}$. per head). ${ }^{1}$

Both the expenditure and the debt-as is admitted even by critics strongly opposed to the German occupation of Alsace-Lorraine - -were necessary and fully justified; a bold financial policy was needed for the purposes of public organisation and economic development. The merits of German administration -activity, method, precision-are recognised by the Alsatians, though they have sometimes felt that the governing authorities might have been a little more economical in the use of public money, especially in regard to the high salaries paid to officials, who for the most part are Germans. Impartial judges, however, will agree that in order to secure competent and efficient officials it is indispensable to offer them adequate, indeed, attractive, salaries; so that the Alsatian reproach of "dispendieuse mégalomanie" s is not merited, at all events in this respect. A comment of striking significance here is that in 1872 the deposits in the savings banks of the provinces amounted to 7,500,000 marks, whilst in recent years they attained a total of $I 78,000,000$ marks. Further, it is admitted that the schemes and incidence of taxation have changed for the better since the annexation of the territory."

Public instruction of all grades is admirably organised and adequately endowed. In regard to elePublic mentary education, there are 3,846 schools, instruction. with 4,I38 masters and 4,053 mistresses and 320,000 scholars. For secondary instruction, which requires a budget of $2,000,000$ to $3,000,000$ marks,

1 Wetterlé, loc. cit.; Lichtenberger, op. cit., p. 105.

2 E.g. Lichtenberger, ibid.

3 Ibid., p. I07. "Wetterlé, op. cit., p. $294 . \quad{ }^{5}$ Ibid., p. roo. 
there are I5 gymnasiums (grammar-schools) and I3 realschulen (modern schools), containing 700 masters and I0,000 pupils. Excellent provision is made for technical and professional training; the School of Chemistry at Mülhausen is an institute of European reputation. Finally, the University of Strassburgfor which the annual expenditure is I,800,000 marksis one of the finest and best equipped on the Continent ; and its organisation is universally praised and admired. In 1872 it had 47 professors and lecturers and 220 students, now it has I76 professors and lecturers and 2,200 students; and it contains a library of nearly a million volumes. There can be no doubt that the various kinds of continuation schools and technical institutes have greatly contributed to the commercial expansion and industrial prosperity of the Reichsland. As MM. Lichtenberger testify: “L'enseignement post-scolaire, les écoles d'adultes, les écoles d'apprentissage, l'enseignement technique sont admirablement organisés en Alsace et ont certainement contribué, pour une bonne part, à la prospérité industrielle du pays." 1

Whatever disadvantages were inherent in and whatever hardships * resulted from the German administration, there can be no doubt that it also brought about great economic and educa- Great protional progress, as well as true religious German rule. liberty. We may sum up in the words of a wellknown French writer: "Under the German rule, Alsace-Lorraine received an impulse which it had not known before the annexation. Schools, roads, railways, public places, monuments, factories, large shops, transformed old Alsace and French Lorraine.

1 Op. cit., p. II5.

2 That there were many will be seen in chap. ix. 
After French administration, so conventional and so nonchalant, German administration, even if still somewhat rough in its methods, seemed a wonderful fairy of initiative and intelligence, and the same comparison between the commercial bourgeoisie of France and of Germany was forced on us; the more the one appeared conventional and timid, the more the other seemed bold and enterprising." "

Having now considered the nature of the question of Alsace-Lorraine and the present position of the provinces, it is necessary to set forth the principal historical facts in order to appreciate the character of the contending claims and the issues involved.

1 G. Hervé, L'Alsace-Lorraine (Paris, x913). 


\section{CHAPTER III}

\section{HISTORICAL OUTLINE}

Roman occupation-Germanic invasions-Union with the German Empire.

(a) Lorraine: Middle Ages-Relations with France-Certain annexations to France-The Three Bishoprics-Cession to France. (b) Alsace : Middle Ages-Part of Germany till the seventeenth century-The Thirty Years War-Treaty of Westphalia ( $66_{4} 8$ )-Position of StrassburgThe French Revolution; Union with France.

THE regions of Alsace-Lorraine inhabited by such tribes as the Rauraci and Sequani, formed part of ancient Gaul; they extended from the Roman Atlantic to the Rhine, and were subjected occupation. to the Roman dominion through the conquests of Julius Cæsar. For five centuries they constituted a colony of the Roman Empire, being included in the provinces of Germania Superior and Maxima Sequanorum. The results of the Roman occupation, e.g. the founding of towns, such as Strassburg, Metz, Verdun, Saverne, and the construction of roads and monuments, are visible in various parts of the country. To the east of the Rhine was a region of forest land inhabited by barbarians who frequently crossed over the river into the adjacent lands on depredatory enterprises, and with the help of the Roman and Gallic legions were driven back.

Early in the fifth century, however, the provinces were more extensively ravaged by bands of Goths, Alani, and other Germanic tribes, who Germanic broke in successive waves over Gaul and invasions. the Roman Empire. The former Roman colony was 
occupied on the south by the Alemanni, and in the north by the Franks. About A.D. 500 the Alemanni were overthrown by Clovis, the Merovingian king, at the battle of Tolbiac, and were driven beyond the Rhine, so that the territories on the left bank passed under the sway of the Franks. Immediately afterwards followed the conversion to Christianity of Clovis and thousands of his soldiers, who were baptized by Remigius, Bishop of Rheims, conformably to the victor's promise made before the great battle. Many of the old names in the conquered country were then supplanted by new ones; thus the designation Alsatia or Elsass came into use, being derived from the river Ell or Ill, which falls into the Rhine at Strassburg.

For some time during the Merovingian period it formed a duchy attached to the Austrasian kingdom, Merovingian with Metz as the capital, and was governed period. by the successors of Duke Eticho, one of whom was St. Odilia, to whose shrine Alsatians still make pilgrimages.

Under Charlemagne it participated in the military charle- expeditions to the interior of Germany; magne. and at his death (A.D. 8r4) the Frankish empire fell to pieces, and Alsace-Lorraine, along with it, was divided into countships.

By the Treaty of Verdun (A.D. 843), the original kingdom of Lorraine passed to the Emperor Lothair I, and in A.D. 855 his second son, King Lothair, succeeded to it. It then comprised not only the territory that was afterwards designated Lorraine, but also the regions corresponding to what is now Holland and Belgium, portions of Rhenish Prussia, of Switzerland, and of the old province of Franche-Comté. A century later the entire country received the name of Lotharingia. 
Towards the end of the ninth century, when the empire was divided between Charles the Bald and Louis the German, Alsace and Lorraine Union with were united to the German Empire. Alsace German was now settled by Germans of Alemannic empire. stock, akin to those who had colonised a great part of the territories now comprised in Baden, Bavaria, and North Switzerland; and Lorraine was occupied by Franks and Franconians-the Vosges or Wasigen Mountains forming a barrier between the Germanspeaking and the Romance-speaking peoples.

It will now be convenient to deal with Lorraine and Alsace separately, as for some centuries they followed different destinies.

\section{(a) LoRraine}

At the beginning of the tenth century Lorraine was converted from a countship into a duchy. In A.D. 944 Otto the Great gave it to Conrad the Red, Duke of Franconia, and on the latter's revolt took it away again and asMiddle signed it to Bruno, Archbishop of Cologne (A.D. 954). Owing to the sedition of Lotharingian nobles, Bruno divided the duchy into Lower Lorraine (given to a Duke Godfrey, who was styled Dux Ripuariorum), and Upper Lorraine (given to Frederick, Count of Bar, styled Dux Mosellanorum). After numerous changes Lower Lorraine was assigned by the Emperor Henry $\mathrm{V}$ in IIo6 to Godfrey, Count of Louvain, the first hereditary Duke of Brabant, and was afterwards designated Brabant. From the eleventh century the duchy of Upper Lorraine came to be known simply as Lorraine. Among its fiefs were the three ecclesiastical lordships of Metz, Toul, and Verdun- 
described as the Three Bishoprics-which enjoyed almost complete independence.

In I3r5 Verdun and Toul placed themselves for a short time under the protection of the King of France. Relations Metz, above all, was on terms of close friendwith France. ship with France, and very cordial relations existed between the pays messin and Louis XI, Charles VIII, and Louis XII. When a French king was crowned at Rheims, several Messins attended and received the honour of knighthood; similarly they participated in the solemnities consequent on the death of a French sovereign. The French language was predominant in Metz.

In the middle of the sixteenth century a considerable portion of Lorraine territory was definitively

\section{Certain} annexed to France. At this time Germany annexations was much divided up, and cannot yet be to France. described as constituting a nation. ${ }^{1}$ Metz, Toul, ard Verdun, which had long shaken off the dominion of the bishops, were governed as independent republics, recognising only a nominal suzerainty of the Emperor of the Romans. Charles $V$ opposed the spread of Protestantism, and endeavoured by forcible measures to bring back to the Roman Catholic Church princes and communities who had adopted the reformed religion. Whereupon the Protestant princes, notably Maurice of Saxony, took up arms and appealed for protection to Henry II of France (husband of Catherine de' Medici). The latter accordingly entered into alliances with the German Reformers, towards the end of I55I, raised an army of 36,000 men (more than half of whom were German and Swiss mercenaries), and invaded Lorraine early in

1 Cf. A. Eckel, La réunion de l'Alsace et de la Lorraine à la France (Vesoul, I894). 
I552. Toul readily surrendered without offering any resistance. In April I552, Metz was occupied by Montmorency. Henry II then crossed the Vosges into Alsace, and tried to take Strassburg, but failed. He took possession, however, of Hagenau and Weissenburg, and, after recrossing the Vosges, occupied Verdun.

Thus, the three Lotharingian bishoprics, comprising the three towns and dependent territories, became part of the French dominions. In The Three I553 Charles V tried to retake Metz, but Bishoprics. after a siege of two months was compelled to retire with heavy loss, before the resistance of Duke Francis of Guise. Under the Treaty of Cateau-Cambrésis, April I559, France was obliged to surrender various conquests, but was permitted to retain the Three Bishoprics: "She lost as many provinces as she gained cities." The newly acquired territories, which were already French in language and sentiments, were rapidly assimilated to France in every other respect, and gave their new country illustrious sons (such as Marshal Fabert of Metz) who were ready to sacrifice themselves in its service.

The possession of the Three Bishoprics facilitated and promoted French relations with the duchy of Lorraine generally, and paved the way for the definitive acquisition of the latter. The Duke of Lorraine was in several respects in a peculiar position. In the first place, his subjects were some of French origin and some of German; the people inhabiting the banks of the Moselle, in the neighbourhood of Nancy, Épinal, etc., spoke French, whilst those inhabiting the banks of the Sarre, near Sarreguemines, Sarrebourg, and Phalsbourg, spoke German. Secondly, he owed homage to the French sovereign for the county of Bar-le- 
- Duc, but the remainder of his possessions acknowledged the suzerainty of the Emperor of Germany. Thus the division of his interests and obligations affected his policy. In the reign of Duke Charles (surnamed the Great), the duchy suffered much from German bands who passed through it on their way to help the Protestants in France, as well as from disturbances due to the progress of Calvinism. His son, Henry II (the Good), expelled the invaders.

Duke Charles IV (or III), having harboured French malcontents, Louis XIII invaded Lorraine and obtained French the cession of several fortresses (I63I-3). invasion. The duke then abdicated and withidrew to Germany, whereupon the Parlement of Paris adjudged him guilty of rebellion, and confiscated his estates. By the Treaty of Vincennes (I66I) he recovered the duchies of Lorraine and Bar, but ceded Clermont, Sarrebourg, and Phalsbourg. The following year he transferred the succession to the duchy to Louis XIV for a life-rent, but the Lorrainers refused to ratify the transaction. Lorraine was then occupied by Marshal de Créqui. The ducal estates were not restored till I697, when, under the Treaty of Ryswick, Duke Leopold regained them, but was obliged to dismantle the fortresses of Lorraine, and to disband nearly the whole of his army. During the latter's reign great progress was made in the duchy, and French immigrants were welcomed.

After the death of Leopold, his heir, Francis III, was betrothed to Maria Theresa, the daughter and Cession to heiress of the Emperor Charles VI. But France. France opposed the union of Lorraine with the Empire. By the Treaty of Vienna (I735) the duke exchanged Lorraine for the duchy of Tuscany; the former was given to Stanislaus Leszczynski, the 
dethroned king of Poland and father-in-law of Louis XV, and on his death (A.D. I766) passed to the French king conformably to the stipulations of $\mathbf{2 7 3 5}$. Thus the acquisition of the territory was effected by way of a regular and legitimate cession, and not by conquest.

\section{(b) Alsace}

After the death of Henry I, King of the Germans, Alsatia (or Elsass) was re-established as a duchy, and remained in the possession of the Hohen- Middle Ages. staufen House till I273, when Rudolf III of Habsburg was elected King of the Romans. (The Imperial dignity was vested in the House of Habsburg from I438-I740, and from 1745 until the dissolution of the Holy Roman Empire in 1806.) At the beginning of the twelfth century the country was divided into the two landgraviates of Upper Alsatia (the Sundgau) and Lower Alsatia ; but, owing to the continual disintegration of the great duchies and the multiplication of principalities and minor lordships in the Empire, the Emperors established numerous free towns for the purpose of combating the growing power of the princes and lesser nobles. In the latter part of the fifteenth century there were some eighty Free Imperial towns in the Empire, most of which were situated in southern or western Germany ; and the traditions of freedom in Alsace go back at least to the middle of the fourteenth century, when the League of Free Cities was established (I353), at the suggestion of the Emperor Charles IV, and existed for over two centuries. It included Hagenau, Colmar, Schlettstadt, Weissenburg, Münster, Türkheim, Kaisersberg, Oberehnheim, Rosheim, and Mülhausen. Landau entered the league in I5II, but in I523 Mülhausen 
left it to join the Swiss Confederation. These " free towns" enjoyed autonomy, though not complete independence.

Till the seventeenth century Alsace was part of Germany; in the Middle Ages it was one of the cradles Part of of German thought, civilisation, art, and Germany architecture. In the thirteenth and fourtill seven-
teenth century. the "Gottesfreunde" (the "Friends of God"), with Johannes Eckhart and Johann Tauler at their head, prepared the way for the Reformation. In the earlier part of the fifteenth century, Gutenberg set up his printing-press at Strassburg; and Martin Schongauer, the leading engraver and painter of the early German School, established a school of engraving at Colmar, which produced the "little masters" of the following generation and a group of Nuremberg artists. Nearly the whole of Alsace accepted the reformed doctrines, Martin Bucer being their foremost champion in Strassburg about I523. In I530 the latter city joined the religious and political league known as " das christliche Bürgerrecht," which Mülhausen had entered the year before; and through the succeeding period of Catholic persecutions and religious dissensions Strassburg was piloted by Jacob Sturm von Sturmeck, who obtained from the Emperor favourable terms for his native city at the termination of the Schmalkaldic ITar.

In the Thirty Years War, France intervened at the instance of several German princes. After the defeat Thirty of Duke Bernhard of Saxe-Weimar at Years War. Nördlingen (1634), Richelieu demanded, as the price of his assistance, the Alsatian fortresses held by the former, and in May 1635 declared war against Spain. In I638 Bernhard crossed the Rhine near Basle at the head of the Swedish army 
(which he commanded after the death of Gustavus Adolphus), and took possession of Alsace. But in the following year he died, and his army was taken over by France; and subsequently the French, under Condé, broke the Spanish power in the Netherlands, and under the same leader and Turenne they rolled back the leaguers through the Palatinate and Bavaria, and gained a victory at Nördlingen (I645).

In the ensuing peace negotiations France claimed the cession of Alsace in consideration of her intervention, which had saved Germany from the despotism of the Austrian house. This claim Westphalia gave rise to disputes, which are reflected in (I648). the obscure text of the Treaty of Münster (Westphalia). The relevant provisions are contained in Articles 75, 76, and 89. Article 75 indicates the extent of the territory ceded to France by the Emperor, viz. the two landgraviates of Upper and Lower Alsace, Sundgau, and the prefecture of the ten free imperial towns, except Strassburg. Article 76 stipulates that the said territories shall be incorporated into France in perpetuity, and that neither any Emperor nor any Austrian prince shall ever lay claim to them. In view of this provision, which expressly confers on France the rights of sovereignty over the ceded territories, Article 89 appears to be ambiguous and contradictory. The latter lays down that the King of France is to maintain Alsace "in that liberty and possession of immediacy towards the Roman Empire which it has hitherto enjoyed" (" in ea libertate et possessione immedietatis erga Imperium Romanum qua hactenus gavisæ sunt") ; and he is not to exercise royal power, but only the rights which the Emperor possessed. Thus what is conferred by Article $7^{6}$ is apparently denied by Article 89 ; but this restriction is again 
modified by the subsequent clause, which says that the present declaration is not to be understood as detracting from the sovereign power recognised above (" ita tamen ut præsenti hac declaratione nihil detractum intelligatur de eo omni supremi dominii jure quod supra concessum est"). The explanation of these seeming contradictions is that the expression " ea libertate et possessione immedietatis erga Imperium Romanum" implies that the lay and ecclesiastical nobles, together with the Alsatian towns concerned, enjoyed such rights and privileges as placed them in a position of relative independence with regard to the Emperor. Thus the real purport of these difficult clauses seems to be that Alsace is ceded to the King of France, who becomes its sovereign and agrees to protect the said local rights and privileges. ${ }^{1}$

As to Strassburg, which was an imperial free city and an autonomous republic bound by very feeble Position of ties to the Empire, it is not expressly menStrassburg. tioned as being ceded to France; but Article 89 includes it among the other imperial free cities in the provision for maintaining the liberty and "possession of immediacy towards the Emperor." However this may be, Louis XIV did not take possession of Strassburg till I68I (when it capitulated to the French troops); though it was thought the treaty transferred it to him equally with the other towns. Two years before this, the Treaty of Nimeguen, terminating the war between the Emperor and Louis XIV, who tried to seize Holland, confirmed the annexation of Alsace to France, without making any stipulation as to the protection of local rights and liberties. By the Treaty of Ratisbon (Regensburg), I684, Strassburg was secured to France. Shortly 1 Cf. Eckel, op. cit. 
afterwards hostilities were renewed, and continued till I697, when the Peace of Ryswick was concluded, whereby the annexation of Strassburg to France was definitively confirmed. (It is of interest to recall that Louis XIV thereupon received a congratulatory communication from Frederick William, the Elector of Brandenburg, who was the direct ancestor of William II.) In I78I, when the centenary of the cession of Strassburg to France was celebrated, the mayor spoke of the peace and happiness of the town under French rule, and of its attachment and gratitude to its sovereign: "Tous les citoyens de la ville, jouissant depuis cent ans sous la domination de la France d'une tranquillité et d'une félicité inconnues à leurs aïeux, ont marqué le désir unanime de témoigner publiquement leur reconnaissance et leurat tachement." ' The French Government respected the local traditions, liberties, and customs; under its mild régime, wise administration, and moderate taxation the city prospered; the Protestant religion was tolerated, but the cathedral was restored to the Catholic worship. This progress, economic and intellectual, during the eighteenth century was not confined to Strassburg; Alsace, and indeed the whole of France, shared in it. The province was at last delivered from the invasions, ravages, devastations, and bloodshed to which it had for centuries been subjected.

The Revolution of $\mathrm{I} 789$ was hailed with enthusiasm in Alsace. The acclaimed principles of liberty, and then the victories of the Empire, aroused The French in the province a strong French sentiment, Revolution. despite Germanic culture, language, and traditions. Alsatian generals distinguished themselves, and Alsatian soldiers gave their lives in the service of France.

1 J. Heimweh, La Question d'Alsace, p. 97. 
It was in Strassburg that the Marseillaise was composed and first sung (1792). The abolition of feudalism by the National Assembly dissociated Alsace fundamentally and entirely-that is, socially and economically, as well as politically-from the still feudal Germany.

Merlin of Douai, presenting the report of the Comite Féodal, October 28, I790, observed: "The Alsatian Union with people has united itself to the French people France. because it willed to do so ; it is then its will alone, and not the Treaty of Münster, that has legitimatised this union." During the revolutionary disorders Alsace might well have found an opportunity to liberate itself from France, had it chosen to do so; instead of that it voluntarily sealed the union with its blood.

In I8I5 Austria was anxious to acquire possession again of Alsace; but, notwithstanding the hatred and Aim of fear long inspired by France, and the obvious Austria in expediency of impeding her territorial ag1815 . grandisement, the Allies opposed such a project, as it was felt that the provinces in question had become an integral part of France and were essentially French. It is a significant fact that, though numerous nationalist movements arose in Europe during the course of the nineteenth century, none appeared in Alsace-Lorraine until after its annexation by Germany. 


\section{CHAPTER IV}

\section{ANNEXATION OF ALSACE-LORRAINE IN I87I}

(a) Military events leading to peace negotiations: Outbreak of the war of I 870 -Neutrality of the Powers-German successes-Annexation proclaimed-Capitulation of Metz-Siege of Paris-National Assembly at Bordeaux; peace signed. (b) Negotiations and Arrangements as to Alsace-Lorraine: Protests against announced annexation-Bismarck's fear of European intervention-He secures Russian support-His doubt as to territorial demands; military view-Demands made at Versailles - German resolve as to annexation-Bismarck's concession-The Preliminaries of Versailles-Negotiations at Brussels-Difficulties of the French plenipotentiaries-Negotiations transferred to Frankfort-The French plenipotentiaries-Treaty of Frankfort-Belfort-Germans affect to be disappointed-The boundary commission-Rights of in. habitants of ceded territory-Regulation of various other matters.

\section{(a) Military Events leading to Peace NEgOTIATIONS}

ON the evening of July I4, I870, when the "Ems telegram" became known in Paris, war was decided on by the Emperor Napoleon III in Council. The next morning it was announced in the Senate that the Imperial forces were ordered

Outbreak of war in 1870 . to mobilise, and that the Government would " take measures to safeguard the interests and the honour of France." Similar orders were issued on the evening of the same day by the King of Prussia to the armies of the North German Confederation, and mobilisation preparations were begun in South Germany immediately afterwards (July I6). The efforts of Great Britain to preserve peace, by proposing recourse to mediation conformably to Protocol XXIII of the negotiations relative to the Treaty of Paris, I856, 
were not successful ; both sides declined to entertain the proposal. ${ }^{1}$

The French formal declaration of war was received in Berlin on July I9; and a few days later Bismarck published (in The Times, July 25) the draft of a FrancoPrussian treaty, proposed by Benedetti in I866, that Prussia should aid France to acquire Belgium in return for French support in regard to certain annexations in northern Germany. The protest of the French diplomatist that the projected treaty had been drawn up at the dictation of Bismarck failed to allay the excitement in England, where the unfortunate document was regarded as evidence of a recrudescence of French territorial ambitions. Accordingly, Lord Granville without delay concluded treaties with the belligerents (signed at London, August 9 and August II), whereby each undertook to oppose jointly with England any violation of Belgian territory on the part of the other. ${ }^{2}$

Napoleon had hoped to obtain the support of Austria, Italy, and Denmark, as Powers obviously Neutrality opposed to the Prussian policy of aggrandiseNeutrality
of the Powers. their neutrality. Thus France, besides being militarily unprepared-every department of her army being in a state of hopeless confusion-found herself diplomatically isolated; and in such unpropitious circumstances the campaign opened.

The operation at Saarbrücken, August 2, in favour of France, was followed by German victories at SpichGerman eren and Weissenburg (August 4), and the successes. decisive defeat of Marshal Macmahon's army at Wörth (August 6). After various political and

1 Cf. Earl Granville to Lord Lyons, etc., July 15, I870: Parliamentary Papers, vol. Ixx. (1870), p. 57 : British and Foreign State Papers (1869-70), vol. Ix, p. 833 .

2 British and Foreign State Papers, vol. 1x. pp. 10, 13. 
military changes were hastily effected in France, the German armies followed up their successes by crossing the Vosges (August II). On August I6-I7 ensued the sanguinary engagements of Vionville, Mars-laTour, and Gravelotte, and on the Igth the investment of Bazaine's army in Metz was begun. On September I the battle of Sedan ended in the surrender of Napoleon.

Thus in the short space of one month one of the French armies was destroyed, another was locked up in Metz, and the Germans were free to march upon Paris. It was now that the victorious invaders had determined that the cession of the fortresses of Strassburg and Metz with their surrounding territories-i.e. Alsace and Lorraine-should be an indispensable condition of peace. After Sedan followed the fall of the Empire, the establishment of the Republic, and the constitution of a Government of National Defence. A second seat of government was set up at Tours; and, the separatist movements developing in France, Gambetta assumed the dictatorship (October 7), and for a time put an end to dissension.

In the meantime the annexation of Alsace and of Eastern Lorraine was proclaimed after the surrender (September 28) of Strassburg, the key of Annexation Alsace. A few days before (September I9), proclaimed. during the investment of Paris, Jules Favre had an interview with Bismarck at Ferrières; and, in reply to the latter's territorial demands, the representative of the Provisional Government declared that France would not cede an inch of her territory or a stone of her fortresses.

On September I3 Thiers, notwithstanding his advanced age, had started on a mission to the Courts of London, St. Petersburg, Vienna, and Florence in 
the hope of securing their mediation, even if only for the conclusion of an armistice so that the elections might be held. But the time was ill-chosen, and he received little encouragement.

After French successes in the Loire Valley, the Germans occupied Orleans on October II, which they Capitulation afterwards lost. On October 27 Bazaine of Metz. surrendered at Metz; and, after various reverses of the French in the campaign of the Loire, Orleans was recaptured by the Germans on December 4, and a panic throughout Touraine was thereby created. The seat of administration of the Provisional Government was now removed to Bordeaux.

In the meantime the capital was undergoing the terrible trials of the siege ; and, in these circumstances, Siege of added to the fact that Bourbaki's army was Paris. compelled to begin its disastrous retreat, Favre had an interview with Bismarck at Versailles, January 23, I87I, for the purpose of arranging the terms of a general armistice and of the capitulation of Paris.

On January 28 a three weeks' armistice was signed; in the interval a National Assembly was to be elected National and summoned for the purpose of deciding Assembly at on the continuance or definitive cessation of Bordeaux. hostilities. Gambetta was for continuing the war, and declined to accept the authority of the Paris Government to act on behalf of the country; but his policy gained few adherents, and he therefore resigned. On February I2 the National Assembly was opened at Bordeaux; the Provisional Government declared its functions at an end; Thiers was appointed head of the executive (February I7), and, together with Favre and Picard, was commissioned to conclude peace. 
The Preliminaries of Versailles were signed on February 26, ratified by the National Assembly on March 3, and the definitive Treaty of Peace Frankfort was concluded on May Io, and the signed. ratifications were exchanged at Frankfort on May 20.

(b) Negotiations and Arrangements as to AlsaCe-LORRAINE

It has been pointed out that in the middle of September M. Thiers sought, without success, the interposition of the British, Russian, Austrian, and Italian Governments, and that the annexation of Alsace and Eastern Lorraine was proclaimed after the capitulation of Strassburg, which took place on September 28.

Subsequently, the French resistance to the investment of the capital having unexpectedly revived with renewed vigour and determination, protests began to be made in various quarters against Protests the German projected annexation, involving, announced as it was thought, a repudiation of previous treaties; and a joint intervention of the Powers was suggested to prevent the dismemberment of France. Bismarck avowed his fear of such intervention. $\mathrm{He}$ was anxious to end the war speedily-and particularly so, owing to the continued large German losses-by bringing up heavy artillery against $\begin{array}{r}\text { Bismarck's } \\ \text { fear of }\end{array}$ Paris, instead of attempting to reduce the intervention. city by famine. "In the Council of War," he observed," "Roon was the only supporter of my opinion that we should lose no time about ending the war if we wanted to make sure of stopping interference from the neutrals and their congress. ... . The delay in the decision caused me more serious dis-

1 Bismarck: the Man and the Statesman, English translation (London, I898), pp. I07, I08, I I I. 
quietude in the political sphere from my anxiety respecting the intervention of neutrals... . An intervention could only tend to deprive us Germans of the prize of victory by means of a congress. This danger, which troubled me day and night, made me feel the necessity of hastening the conclusion of peace, in order to be able to establish it without the intervention of neutrals."

However this may be, amongst European statesmen Count von Beust appears to have been the only one who made any attempt to bring about a collective intervention of the neutral Powers. On September 28, following on the appeal of M. Thiers, he sent a despatch to that effect to the Austrian ambassador in London ${ }^{1}$; and again on October I 2 he communicated with Count Chotek, the Austrian ambassador in St. Petersburg, suggesting a European intervention in order " to moderate the demands of the conqueror and soften the bitterness of the sentiments which must crush the vanquished." 2

But Bismarck's diplomatic skill in definitely securing the good-will of Russia made such an eventuality Bismarck impossible. Russia had for some time been

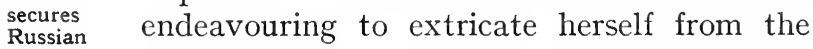
support. difficult position imposed on her by the Treaty of Paris, 1856 , and the Straits Convention of the same date. $^{3}$ Already in I866, during the Austro-Prussian War, King William of Prussia had been assured of the friendship of the Emperor Alexander, and in return had manifested his sympathy with the determination of Russia to bring about an abrogation of the ob-

1 Count von Beust, Aus drei Vieriel-Jahrhwnderten (Stuttgart, 1887), Pt. II., pp. 36r, 395.

Ibid., p. 397.

${ }^{3}$ See C. Phillipson and N. Buxton, The Question of the Bosphorus and Dardanelles (London, 1917), pp. 81 seq. 
noxious clauses of the above-mentioned treaties. ${ }^{1}$ Now, in I87o, Bismarck sent a despatch (dated Ferrières, September 20) to Prince Reuss, the Prussian minister in St. Petersburg, declaring that King William deemed the Tsar's intended repudiation of the treaties to be justifiable, and that Prussia, in her hour of victory, would do her utmost to get not only France, but also the other signatory parties, to recognise the denunciation. Soon afterwards (October 9) Bismarck made it everywhere known that a close entente existed between Prussia and Russia; and then Prince Gortchakoff issued his famous circular despatch, dated October I9-3I, I870, announcing his Government's withdrawal from the restrictive articles of the Conventions of 1856.

Having ensured a clear field for negotiation, Bismarck, it appears, began to feel some doubt as to the expediency of insisting on such large territorial His doubt demands as had been announced to France. $\begin{gathered}\text { as to } \\ \text { territorial }\end{gathered}$ Even after the conclusion of the armistice demands. (January 28), when France was virtually at the feet of Prussia, he is reported to have been in conflict with Moltke and the military party who, in their inordinate exactions, were disposed to show little consideration and to brook no compromise. The German Emperor was obliged to intervene on at least one occasion to adjust these differences between the diplomatists on the one side and the military leaders on the other. For a considerable length of time the Chancellor adhered to the view that Germany ought not to insist on the cession of Metz and the adjacent territory, and he did not regard the military party's arguments for annexing this locality as decisive. He thought it would suffice to dismantle the fortress, and believed

${ }^{1}$ Phillipson and Buxton, op. cit., p. 103

${ }^{2}$ Ibid., pp. I05 seq. 
that security could be assured by constructing another strong place behind it.

"If they were to give us another milliard," he is reported to have said, " "we might perhaps leave Metz, Influence of and build a fortress a few miles farther back military in the neighbourhood of Falkenberg, or circles. towards Saarbrücken. ... I do not want so many Frenchmen in our house. It is the same with Belfort, which is entirely French. But the soldiers will not hear of giving up Metz spoken of, and perhaps they are right." The words italicised show, however, that Bismarck could be prevailed upon to abandon his own views in favour of others, if he was convinced that the latter would more effectively serve the interests of his country-regardless of whatever humiliation or burden might thereby be inflicted on any other country.

The demands laid before M. Thiers by Bismarck at Versailles, February 2I, I87I, included the cession Demands of Alsace and Metz, together with the part made at Versailles. of Lorraine constituting the Department of the Moselle, the payment of a war indemnity of 6,000,000,000 francs (which he did not think excessive), ${ }^{2}$ and the occupation of French territory till payment was completed. He mentioned also Nancy, "which the Headquarters Staff wished to keep"; and referred to Savoy and Nice, which France might retrocede to Italy. In the long discussion that followed Thiers with difficulty suppressed his emotion; he declared that the demands were monstrous, that the exorbitant indemnity must have resulted from the dreams of military men and not from the sober

1 M Busch, Bismarck: some Secret Pages of his History, Eng. trans. 3 vols. (London, 1898), vol. i. pp. 556-7; cf. Ottokar Lorenz, Kaiser Wilhelm und die Begründung des Reichs, I866-71 (Jena, 1902), pp. 520 seq.

${ }^{2}$ Cf. G. May, Le Traité de Francfort (Paris, I909), pp. I63 seg. 
calculations of financiers; and he suggested to Bismarck that, if he seriously insisted on such terms, he had better take upon himself the government of France, and that the existing administration would retire.

On the following day Thiers, having come again to Versailles, asked to see the German Emperor, in the hope of getting more favourable terms German from him. But the latter spoke only of Emperor's the entrance of the German troops into Paris; annexation. and on other questions Bismarck had already taken precautions, for he remarked to the French representative: "The Emperor does not wish to speak of business except in the presence of his ministers." M. Thiers saw also the Crown Prince, on whom he seems to have had some effect: "The old man," says M. Hanotaux, " broken with fatigue and emotion, speaking with eloquence of the war which he had wished to avert, of the fault of the Imperial Government, of the dangers which an ill-advised peace would cause to Europe, touched the sensitive soul of the Crown Prince." 1 He declared that the abandonment of Metz would be intolerable to France, and that, if such extravagant demands were persisted in, the resumption of hostilities would become inevitable. He emphasised that the sum of the indemnity mentioned the previous day should be considerably reduced, and he opposed the entrance of German troops into the capital. The Crown Prince appeared to his entourage to be willing to renounce Metz; but his confidential friend, General von Blumenthal, said that " it turned the heart in one's body to renounce Metz and leave Paris, looking like a fool."

1 G. Hanotaux, Contemporary France, English translation, 4 vols. (London, I903), vol, i. p. I22.

2 Ibid. 
The next day (February 23), the Emperor, who did not take the same view as his son, having conferred Bismarck's with the Grand Duke of Baden, exclaimed Bismarck's
refusal to give way. question of Metz. In the interview of Thiers and Favre with Bismarck at Versailles the Chancellor was reminded that in the preceding November he had promised that France would not be dispossessed of Metz. "What was possible in November," replied Bismarck, " is no longer possible to-day, after three months' bloodshed"; and he added that if France was not ready to give up Metz an immediate rupture of the negotiations was necessary.

On February 24 another conference was held, when Thiers expressed the firm resolve of France not to Bismarck's cede both Metz and Belfort. After some concession. deliberation and consultation with Moltke and the Emperor, Bismarck announced that he would give way in regard to Belfort, and that the amount of the indemnity would be reduced by a milliard, thus leaving a sum of 5,000,000,000 francs. ${ }^{1}$ (It may be pointed out that the reduction in what the French called the "ransom" was effected at the instance of the British Government "; even then, the remaining sum was the largest pecuniary indemnity ever exacted in the history of war.)

On February 26 the Preliminaries of Versailles were signed. ${ }^{3}$ Then M. Thiers and M. Favre left Versailles for Paris. "Seated in the carriage," says

1 Jules Favre, Le Gouvernement de la Deffense Nationale, 3 vols. (Paris, I871-5), vol. iii. p. IoO.

a C. Gavard, Un Diplomate à Londres: Lettres et Notes, Is7I-7 (Paris, 1895), pp. 3, 4; C. Phillipson, Termination of $W$ ar and Treaties of Peace (London, 1916), pp. 274, 275 .

${ }^{3}$ For the complete text of the Preliminaries see Phillipson, Termination of $W$ ar and Treaties of Peace, Appendix (J), pp. $3^{80-83}$. 
M. Jules Favre, " we did not find a word to exchange during the whole journey ; my heart was so heavy that it suffocated me. Motionless, and Prelimiheavy that it suffocated me. Motionless, and naries of as it were struck down, M. Thiers gave way to his emotion. From Versailles to Paris his eyes did not cease to fill with tears. He wiped them away without saying a word, but it was easy to see, from the expression of his troubled features, that he was a prey to one of the most ineffable sorrows that it is given to man to feel." '

The Preliminaries of Versailles disposed of AlsaceLorraine in the following terms:

"Article I.-France renounces in favour of the German Empire all her rights and Stipulation titles over the territories situated on the east Lorraine. of the frontier hereafter described.

"The line of demarcation begins at the north-west frontier of the canton of Cattenom, towards the Grand Duchy of Luxemburg, follows on the south the western frontiers of the cantons of Cattenom and Thionville, passes by the canton of Briey, along the western frontiers of the communes of Montjois-laMontagne and Roncourt, as well as the eastern frontiers of the communes of Marie-aux-Chênes, St. Ail, Habonville, reaches the frontier of the canton of Gooze, which it crosses along the communal frontiers of Vionville, Bouxières, and Onville, follows the southwest frontier, south of the district of Metz, the western frontier of the district of Château-Salins, as far as the commune of Pettoncourt, taking in the western and southern frontiers thereof to follow the crest of the mountains between Seille and Moncel, as far as the frontier of the district of Sarreburg, to the south of Garde. The demarcation afterwards coincides with the 
frontier of that district as far as the commune of Tanconville, reaching the frontier to the north thereof, from whence it follows the crest of the mountains between the sources of the White Sarre and Vezouze, as far as the frontier of that canton of Schirmeck, skirts the western frontier of that canton, includes the communes of Saales, Bourg-Bruche, Colroy-la-Roche, Plaine, Ranrupt, Saulxures, and St. Blaise-la-Roche of the canton of Saales, and coincides with the western frontier of the departments of the lower Rhine and the upper Rhine, as far as the cantons of Belfort, the southern frontier of which it leaves not far from Vourvenans, to cross the canton of Delle at the southern limits of the communes of Bourogne and Froide Fontaine, and to reach the Swiss frontier skirting the eastern frontiers of the communes of Jonchery and Delle.

"The German Empire shall possess these territories in perpetuity in all sovereignty and property. An international commission, composed of an equal number of representatives of the two High Contracting Parties, shall be appointed immediately after the exchange of the ratifications of the present treaty to trace on the spot the new frontier, in conformity with the preceding stipulations.

"This commission shall preside over the division of the lands and funds, which have hitherto belonged to districts or communes divided by the new frontiers; in case of disagreement in the tracing and the measures of execution, the members of the commission shall refer to their respective Governments.

"The frontier, such as it has just been described, is marked in green on two identical copies of the map of the territory forming the Government of Alsace, published at Berlin in September I870 by the geographical and statistical division of the Staff, and a 
copy of which shall be annexed to both copies of the present treaty.

"Nevertheless, the alteration of the above tracing has been agreed to by the two Contracting Parties. In the former department of the Moselle, the villages of Marie-aux-Chênes near St. Privat-la-Montagne, and Vionville to the west of Rezonville, shall be ceded to Germany. In exchange therefor France shall retain the town and fortifications of Belfort, with a radius which shall be hereafter determined upon." "

It was stipulated in Article VII of the Preliminaries of Versailles that the opening of negotiations for the definitive treaty of peace should take place Negotiations at Brussels immediately after the ratification at Brussels. of the former. This formality was complied with on March 2, I87I; but, owing to the faulty diplomacy of the French Government-obviously due, however, to the internal disorders and to the rapid succession of military disasters - the French plenipotentiaries, Baron Baude, the minister in Belgium, and M. de Goulard, a member of the National Assembly (who were to be assisted by two commissioners), did not reach Brussels before March I9 and 24 respectively. The German delegates were Herr von Balan, the minister in Belgium, and Count von Arnim, the minister at the Papal Court, to whom were added representatives from the kingdoms of Bavaria and Würtemberg and the Grand Duchy of Baden.

The first meeting of the peace plenipotentiaries took place on March 28, when various preliminary and formal matters, such as the exchange and Difficulties of verification of the delegates' full powers, the French were transacted. The next meeting revealed tentiaries. the exceptional difficulties that would be met with

1 Hertslet, Map of Europe by Treaty, vol. iii. (1875), pp. I913, I914. 
in the course of the negotiation, owing to the attitude, methods, and tactics adopted by the German representatives. The writer may be permitted to quote on this point what he has said in a recent publication": "The German plenipotentiaries were determined to exact the last ounce that could be squeezed out of the Preliminaries; indeed, they were not always very scrupulous as to whether their various exactions were juridically and equitably compatible with those Preliminaries. They were opposed to all suggestions that savoured of compromise, and refused to make any concessions even in details. They disregarded the customary procedure, whereby differences of view and partial agreements are recorded in the procès-verbaux or the protocols; they had recourse to the latter only when they succeeded in enforcing agreement or acquiescence in regard to the definite and final drafting of an article. They seem to have adopted, too, the practice of producing a number of propositions on diverse subjects at the same time, regardless of order, system, or intelligible classification; such a course could not but increase the difficulties with which the French delegates had to contend. Throughout the discussions the French negotiators were no match for their opponents. Several reasons may be given for this inequality. In the first place, the latter had the moral and physical support of their military victories; their troops were still on French territory, and might, at the word of command, renew their havoc against a vanquished and well-nigh helpless nation. Their verbal arguments had therefore the sanction of force behind them. They were in a position to dictate terms, and not in the humour to submit to suggested amendments thereto. They more

1 C. Phillipson, Termination of $W$ ar and Treaties of Peace, pp. $137,138$. 
than once threatened to break off negotiations. . . . Secondly, the French delegates were intrinsically inferior; they had had little diplomatic experience, and were manifestly deficient in those qualities that are indispensable in the work of negotiation-dexterity, penetration, decision. ${ }^{1}$ Thirdly, they found themselves at a great disadvantage, in that they had received no instructions from their Government, preoccupied as it was with the internal disorders of France." : It appears, indeed, that they had received only one precise instruction, viz. to demand a plebiscite for the inhabitants of Alsace-Lorraine. ${ }^{3}$

In these untoward circumstances the discussions at Brussels continued throughout April, without arriving at definite conclusions. The German Govern- Negotiations ment became more and more impatient and transferred embittered : for it believed that the French ${ }^{\text {to Frankfort. }}$ representatives had deliberately resorted to dilatory tactics in order to bring about a modification of the Preliminaries of Versailles-indeed, Bismarck made an open charge to that effect in the Reichstag (April 24). On May 4 the negotiations at Brussels were broken off; and Bismarck and Favre agreed to meet personally at Frankfort-on-the-Main on May 6.

The French Minister for Foreign Affairs was accompanied by M. de Goulard and M. Pouyer-Quertier, the Minister of Finance; the German Chancellor was accompanied by Count von Arnim. The French The difficulties of the French representatives tentiaries. by no means diminished in the discussions with the " man of blood and iron." On the one hand, M. Thiers

1 Cf. May, op. cit., p. 44.

$2 \mathrm{~J}$. Valfrey, Histoire du traité de Francfort et de la libération du territoire français (Paris, 1874), Pt. I. pp. I7, 18.

3 Ibid., p. $3^{8}$. 
was anxious to sign the definitive peace as soon as possible, and to avoid protracted negotiations and persistent efforts to combat the German demandsindeed, hedged in on all sides and having just emerged from his conflicts with the Commune, it appeared that he was disposed to make peace at any price, if only it could be effected speedily. On the other hand, M. Favre, the first French plenipotentiary, was lacking in calmness and firmness; his terror-stricken and lachrymose disposition was not of the kind to impress Bismarck favourably and to secure concessions from him. M. Pouyer-Quertier, however, was not intimidated by the bluntness and abruptnesswith the ever-underlying menace-of the Chancellor; whenever the first plenipotentiary gave him an opportunity, he examined and criticised the German claims, and-thanks to his ready Norman wit, urbanity, good sense, and undisturbed composure-he gained more than one point. Thus he prevailed on Bismarck to abandon in the Belfort district the valley of the Marcine, with a French-speaking population, whereby the most direct communication, via Delle, between France and Switzerland was preserved. On the same day he succeeded in obtaining the relinquishment of the commune of Villerupt (containing valuable iron-mines), which had previously been included in the territories to be ceded to Germany, in return for the latter's agreement to extend the radius of the Belfort frontier. Bismarck had just declared he would make no further territorial concessions, whereupon M. Pouyer-Quertier observed: "If you were the conquered party, I give you my word that I would not have compelled you to become a Frenchman, and here you make me a German."

"How is that?" exclaimed the Chancellor. "And 
who is talking of taking your Normandy? I do not understand in the least."

"The matter is, however, very simple, Prince. I am one of the principal shareholders in the forges of Villerupt, and you see clearly that, in this quarter, you make me a German."

"Well, well," said Bismarck, "don't cry about it. I leave you Villerupt. But do not ask me for anything more, or I shall take it back again." 1

The definitive treaty was signed at Frankfort on May Io. The new frontier and the relinquishment of Belfort by Germany in return for $\begin{gathered}\text { Provisions } \\ \text { of Treaty of }\end{gathered}$ the cession of Lorraine territory by France Frankfort. were provided for in Article I:

"The distance between the town of Belfort and the line of frontier such as it had been proposed during the negotiations of Versailles, and such as it is marked on the map annexed to the ratifications of the Preliminaries of the 26th February, is considered as describing the radius which, by virtue of the clause relating thereto in Article I of the Preliminaries, is to remain to France with the town and fortifications of Belfort.

"The German Government is disposed to extend that radius so as to include the cantons of Belfort, Delle, and Giromagny, as well as the western part of the canton of Fontaine, to the west of a line to be traced from the spot where the canal from the Rhône to the Rhine leaves the canton of Delle to the south of Montreux-Château, to the northern limits of the canton between Bourg and Félon, where that line would join the eastern limit of the canton of Giromagny.

1 A. Laussedat, La Délimitation de la frontière franco-allemande (Paris, 1901), P. 5 I. 
"The German Government will nevertheless not cede the above territories unless the French Republic agrees, on its part, to a rectification of frontier along the western limits of the cantons of Cattenom and Thionville, which will give to Germany the territory to the east of a line starting from the frontier of Luxemburg between Hussigny and Redingen, leaving to France the villages of Thil and Villerupt, extending between Erronville and Aumetz, between Beuvillers and Boulange, between Trieux and Lomeringen, and joining the ancient line of frontier between Avril and Moyeuvre.

"The international commission mentioned in Article I of the Preliminaries shall proceed to the spot immediately after the ratification of the present treaty to execute the works entrusted to them, and to trace the new frontier, in accordance with the preceding dispositions."

With regard to the radius round Belfort, the above article gave France the option either of maintaining the $\begin{array}{ll}\text { Belfort. } & \text { radius previously fixed at seven kilometres, } \\ \text { or of receiving such an extension as would }\end{array}$ secure for her nearly the whole administrative district of Belfort; but if she chose the latter alternative she was to abandon to Germany a portion of territory ten kilometres long on the Luxemburg frontier. In the former case, the enlarged zone near Belfort contained some 6,000 hectares (i.e. about 23 square miles), with a population of 27,000 ; in the latter case the territory to be given up in exchange comprised an area of I0,000 hectares (i.e. about 38 square miles), and a population of only 7,000. This arrangement appeared on the whole to be to the advantage of France; but it involved, none the less, the abandonment to Germany of 7,000 inhabitants (who would 
have remained with France had the terms of the Preliminaries been followed), as well as an interference with the communication with Luxemburg, and the sacrifice of a very valuable mining district in the vicinity of Longwy. In the debates in the French Parliamentary Commission and in the Assembly on this proposed exchange of territory, conflicting opinions were expressed as to the expediency and advantage of the exchange. M. Thiers, however, emphasised the strategic value of Belfort, and declared that France would remain rich enough in iron, without the resources of the region near Longwy. Thiers's view prevailed, and the exchange was sanctioned.

When the territorial dispositions were published in Germany various sections of the people, including the military classes, many journalists, and deputies of the Reichstag thought that the Germans acquisitions were inadequate, and that Bis- disappointed. marck had been much too moderate in his demands. In military circles Belfort above all was regretted. Many declared that the German negotiators ought to have insisted also on the cession of Burgundy and Franche Comté, and even suggested the annexation of Dunkirk; it was thought in many quarters that France had been dealt with far too leniently and considerately.

However this may be, when the extent and the character of the acquired territory became known more precisely in Germany, there was not a But really little surprise at the magnitude of the con- surprised at quest, and the economic benefits secured thereby. It not infrequently happens that a party seeking to enter into an unconscionable transaction, or making exorbitant demands on another, loudly proclaims-with his tongue in his cheek-that he is 
really asking too little, and that he is not at all doing himself justice in the arrangement suggested. Colonel Laussedat, who was on the delimitation commission for tracing the new frontier, observes in his work on the subject ${ }^{1}$ that, during the negotiations, he could not but conclude that the conquerors were astonished at their success, and were dazzled by their annexation, that they scarcely believed their own eyes, and could not understand how the French could so promptly give up such a rich territory inhabited by a French population.

The work of the boundary commission took six years: it began in May $187 \mathrm{I}$, and ended on April 26, The bound- 1877 ; and the ratifications thereof were ary com- exchanged at Metz, May 3I, I877. In the mission. course of the topographical labours, the German commissioners disputed the soil foot by foot ${ }^{2}$; where the stipulations of the treaties, which were to serve as a guide, were indefinite or ambiguous they invariably claimed the benefit of the doubt, and pushed their claims to the uttermost limit possible. To the populations immediately concerned, the proceedings were throughout a source of bitter and cruel trials; the staking out of the new boundary was observed with grief and misgiving, and not always with acquiescence; for in many cases, no sooner were the poles and pegs fixed and the commissioners out of sight, than they were all pulled up ; later, even

1 La Délimitation de la frontière franco-allemande, p. I4: "Pendant la durée des négociations auxquelles $\mathrm{j}$ 'ai pris part au sujet du tracé définitif de cette frontière qui mutilait la France et qui, tôt ou tard, c'est mon voeu le plus cher, créera à la Prusse des ennuis inextricables et peut-être mortels, $\mathrm{j}$ 'ai acquis la certitude que nos vainqueurs étaient stupéfaits de leurs succès, éblouis de leur conquête. Ils n'en croyaient par leurs yeux et ne comprenaient pas que nous leur eussions abandonné sitôt une si riche proie, un si merveilleux pays, des populations si françaises!"

2 Ibid., pp. 85 seq. 
many boundary-stones were removed. Colonel Laussedat refers to the frequent scenes, here of despair, there of ardent patriotism, that were witnessed in the course of this sinister severance of people from their mother-country. He relates the following incident:

"It was on the boundary of the two communes of Beuvillers and Boulange. We had all arrived at the first boundary-mark, except the Mayor of Boulange. The German Commissioner, M. Hauchecorne, who had summoned him, was getting impatient, and, seeing him coming in the distance at a walking-pace, and swinging himself about:

" 'Come, Mr. Mayor, hurry up, you are late, and we are waiting for you,' he shouted to him.

"But the Mayor of Boulange, a miller by trade, if I recollect rightly; and with a breadth of shoulder I could not help admiring, seemed to slacken his pace still more; this made the German Commissioner furious, and caused him to fall into the mistake of assuming an authoritative tone, which, by the way, was common enough with him.

" The miller did not put himself out at all, in appearance at least, but slackened his pace still more instead of hastening it; and when he came quite close to M. Hauchecorne-

" 'Ah, there now!' said he calmly, and looking him full in the face, 'do you think, then, that I am in such a hurry to become a Prussian?"

Besides the delimitation of the new frontier, there were various other questions that presented themselves for solution, as a result of the cession of Rights of Alsace-Lorraine. The Preliminaries of Ver- inhabitants sailles had already provided for the commercial territory. and civil rights of the inhabitants of the annexed territory, and for their unimpeded emigration : 
" Article V.-The interests of the inhabitants of the territories ceded by France, in everything relating to their commerce and their civil rights, shall be regulated in as favourable a manner as possible when the conditions of the definitive peace are settled. A certain time will be fixed during which they will enjoy particular advantages for the disposal of their produce. The German Government will put no obstacle in the way of free emigration by the inhabitants from the ceded territories, and shall take no steps against them affecting their persons or their property."

The Treaty of Frankfort afterwards stipulated as follows, with regard to the industrial produce of Alsace-Lorraine :

" Article IX.-The exceptional treatment at present granted to the produce of the industry of the ceded territories for imports into France shall be continued for six months, from the Ist March, under the conditions made with the commissioners of Alsace."

The questions of option, amnesty, archives, registers, etc., pecuniary deposits, ecclesiastical authority, navigation on rivers and canals, and canalisation of the Moselle were thus regulated by the definitive treaty:

" Article II.-French subjects, natives of the ceded territory, actually domiciled in that territory, shall Option. up to the Ist October, I872, and on their making a previous declaration to that effect to the competent authority, be allowed to change their domicile into France and to remain there, that right in nowise infringing the laws on military service, in which case the title of French citizen shall be maintained.

"They shall be at liberty to preserve their immovables situated in the territory united to Germany. 
"No inhabitant of the ceded territory shall be prosecuted, annoyed, or sought for, either in his person or in his property, on account of Amnesty. his political or military acts previous to the war.

"Article III.- The French Government shall deliver over to the German Government the archives, documents, and registers relating to the civil, Public military, and judicial administration of the records. ceded territories. Should any of the documents be found missing, they shall be restored by the French Government on the demand of the German Government.

" Article IV.-The French Government shall make over to the Government of the Empire of Germany within the term of six months dating from the Pecuniary exchange of the ratifications of this treaty ${ }^{1}$ : deposits. (I) The amount of the sum deposited by the departments, communes, and public establishments of the ceded territories. (2) The amount of the premium of enlistment or discharge belonging to soldiers and sailors, natives of the ceded territory, who shall have chosen the German nationality. (3) The amount of security of responsible agents of the State. (4) The amount of sums deposited for judicial consignments on account of measures taken by the administrative or judicial authorities in the ceded territories."

"Article VI.-The High Contracting Parties being of opinion that the diocesan circumscriptions of the territories ceded to the German Empire must agree with the new frontier determined upon by Article I above, will consider, without authority. delay after the ratification of the present treaty, upon the measures to be taken in common upon the subject.

"The communities belonging either to the Re-

1 The ratifications were exchanged at Frankfort on May 20, 1871 . 
formed Church or to the Augsburg Confession, established on the territories ceded by France, shall cease to be under French ecclesiastical authority.

"The communities of the Church of the Augsburg Confession established in the French territories shall cease to be under the Superior Consistories and of the Directors residing at Strassburg.

"The Jewish communities of the territories situated to the east of the new frontier shall cease to depend on the Central Jewish Consistory residing at Paris.

"Article V.-The two nations shall enjoy equal privileges as regards the navigation on the Moselle, Navigation the canal of the Marne to the Rhine, the on rivers canal of the Rhône to the Rhine, the canal and canals. of the Sarre and the navigable waters communicating with those channels of navigation. The right of floatage shall be maintained.

"Article XIV.-Each of the two Parties shall continue on his territory the works undertaken for the Canalisation canalisation of the Moselle. The common of the interests of the separate parts of the two Moselle. departments of the Meurthe and the Moselle shall be liquidated."

Article XVII made provision for the carrying out of such further arrangements as would be necessitated by the due execution of the Preliminaries and the definitive treaty.

To the Treaty of Frankfort were appended a number of supplementary articles concerning the purchase of Regulation French railways and other rights connected

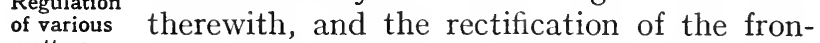
matters. tier near Belfort. In accordance with the above-mentioned Article XVII, more than a hundred conventions were entered into between France and 
Germany. It is beyond the scope of the present work to go into all these details, ${ }^{2}$ so that we must here confine ourselves to mentioning that, by the Additional Convention ${ }^{3}$ concluded at Frankfort, December II, I87I, various important matters affecting the transferred territory were regulated: choice of nationality by natives resident outside Alsace-Lorraine, pensions (civil, religious, and military), execution of judgments, judicial proceedings, exchange of criminals and lunatics, guarantee of mortgage rights, restitution of all titles, documents, etc., belonging to communes detached from their former administration, diocesan circumscriptions crossed by the new frontier, patents, appointment of financial commission, export and import duties, concessions granted by France in the ceded territory, financial regulations relative to canals, railways, renewal of treaties, etc.

1 These are contained, together with many other documents and records, in the voluminous publication of Villefort, Recueil des traités, conventions, bois, decrets et autres actes relatits a la paix avec l'Allemagne, 5 vols. (Paris, 1872-79).

2 For the various arrangements necessitated by, and the various legal and political effects consequent on, a cession of territory see Phillipson, Termination of War and Treaties of Peace, Pt. I., ch. iv. ; Pt. II. chaps. xi. xii. and xiii.

Villefort, Recueil, vol. i. p. 89. 


\section{CHAPTER V}

PROPOSALS AS TO THE FATE OF ALSACE-LORRAINE AFTER ITS CONQUEST-BISMARCK'S VIEW OF THE TASK OF ASSIMILATION

Protests in Germany against the annexation-German policy as to the annexed territory-View as to neutralisation-View as to plebisciteDivision of the territory suggested-Autonomy suggested-AlsaceLorraine made a Reichsland-Bismarck's view as to German assimilation-His doubts about Metz.

When it became abundantly clear, after the fall of Sedan, that the war against France was a war of Protests in spoliation, voices even in Germany were against the raised against the policy of the victors. spoliation. The German Socialists protested publicly and energetically against the projected annexation of French territory. They condemned any arrangement whatever that would involve the humiliation of France and would engender lasting bitterness and an ardent desire for retaliation; they demanded that, in the very interests of the German people, an honourable peace should be granted to France. ${ }^{1}$ On May 25, I87 I, Bebel said in the Reichstag: "I protest categorically against the annexation of Alsace-Lorraine. I consider it a crime against the right of the people; I consider it a disgraceful stain on German history." A similar protest was offered by Liebknecht. For their courageous and enlightened opposition, they were tried

1 Cf. E. Milhaud, La Démocratie socialiste allemande (Paris, 1903), p. 39 ; Novicow, op. cit., p. $3^{8} \mathbf{I}$. 
for high treason and condemned to two years' imprisonment in a fortress.

It is of special interest to recall the observations made in the autumn of I870 by various German leading papers, as showing that it was by no means the entire German people that had become possessed of a conquering fury and territorial lust. The following may be referred to as illustrations :

The Frankfurter Zeitung, August I7, I870: "The annexation of Alsace-Lorraine is shrilly demanded by a section of National Liberals and National Democrats. The powder acts as an intoxicant on the democratic parties. They invoke the brutal right of conquest, and hardly trouble to dissimulate their claims. They do not ask, What do the Alsatians and Lorrainers say? Do they wish to become German or remain French ?"

The Rheinische-Westfaelische Zeitung, August I7, I870: "The question of a French cession of territory is very difficult if we do not merely wish to assert the right of conquest."

The Zukunft, September I8, I870: "They tell us that Alsace-Lorraine must be taken from France. There is no surer way of turning the coming peace into an armistice until the moment when France will have recovered sufficient strength to claim the restitution of the territory we are taking. The most jingoistic Teuton will not dare to pretend that Alsatians and Lorrainers are yearning for the joys of German rule." 1

Germany having compelled France to abandon Alsace-Lorraine, the first problem the German Govern-

1 These extracts were given in the Daily Telegraph, October 19, I9I7, and were supplied to this paper by the Ligue Patriotique des AlsaciensLorrains. 
ment was confronted with was-what was to be German done with the surrendered territory? Was policy as to
the annexed territory. lished German Empire, and, if so, on what basis? Was it expedient to neutralise it and constitute it a buffer State between the rival nations?

In a speech delivered in the Reichstag, May 2, I87 I, Bismarck foreshadowed the future policy that was to be adopted, and criticised certain proposals that had been advanced as against annexation, e.g., the mere dismantling of the French fortresses in Alsace-Lorraine and allowing the territory to remain French; or the neutralisation of the territory. The Chancellor reported a conversation he had had before the FrancoGerman War with the recently deceased King William of Würtemberg. The latter declared he was for peace, but that if war broke out against France he would participate in the conflict. "Give us Strassburg," he observed to Bismarck, " and we shall be united for all eventualities; but so long as Strassburg will remain a sally-port for an armed Power, I fear my country will be invaded by foreign troops before the German Confederation will be able to help me." Thus Strassburg was thought to be the knot of the situation; so long as it was not German it would always be regarded as an obstacle on the one hand to South Germany's committing herself without reserve to German unity, and on the other hand to the development of a German national policy.

As to the suggested dismantling of the French fortresses of Alsace-Lorraine, Bismarck said he strongly objected to such an inadequate scheme. In the first place, he thought it was of little practical use in the interests of maintaining peace. Besides, the geographical configuration of the advanced bastion was 
too near Stuttgart and Munich, so that it therefore became necessary to push it back. Further, Metz, by its topographical nature, was a place that demanded very little works to make a formidable fortress of it, and demolished works could easily be reconstructed. Secondly, political reasons were against imposing on a State restrictions interfering with its self-defence. "To constitute a condition of servitude upon foreign policy and soil is to create a very heavy burden, very annoying to the sentiments of sovereignty and independence of the country upon which it weighs."

The proposed plans to neutralise Alsace-Lorraine, Bismarck said, had many advocates amongst its population. If it were made an independent neutral State, like Belgium and Switzerland, there would thus be a chain of neutral States

View as to neutralisaextending from the North Sea to the Swiss Alps, and separating France from Germany. The Germans, being accustomed to respect treaties and neutrality, would therefore be prevented from attacking the French ; but the French would not be prevented from realising the plan conceived during the last war, viz. to despatch a fleet to Germany with troops for landing, or to land French troops in allied countries and afterwards invade German territory. Accordingly France would be protected against Germany by this belt of neutral States, but Germany would remain exposed to naval attacks, seeing that the German fleet was not as powerful as the French. Furthermore-and this was conceived to be a more important reason against neutralisation-neutrality is tenable only if the neutralised country is resolved to safeguard and defend it ; but if Alsace-Lorraine were established as a neutral State, the strong French elements in it, French sympathies and interests, would induce it to take the side 
of France in the event of a conflict with Germany. Hence there was only one course to adopt, viz. to subject Alsace-Lorraine to German dominion.

Treitschke, writing in $1870,{ }^{1}$ had already condemned (before Bismarck's definitive pronouncement) the proposal to neutralise Alsace-Lorraine. Like so many other Germans, he regarded small nations with impatience and contempt. "What is the use," he exclaimed, "of attempting to answer the suggestion that Alsace and Lorraine should form a neutral State? Has Europe not had enough of that already in the disgusting spectacle of the 'Luxemburg nation'? Only the brain of an English Manchester man, surrounded by the mists he blows from his pipe of peace, could conceive such extraordinary bubbles. No wonder that every enemy of Germany should approve of this suggestion. No better way has yet been thought of to enable France to recover all that she has lost."

To the suggestion that recourse should be had to a plebiscite for the purpose of settling the destiny of view as to the provinces, German opinion was still plebiscite. more strongly opposed. Such a policy naturally finds little favour with those who repudiate democratic demands, who look upon the masses of the people as mere objects of government, and who are animated by dreams of jingoistic imperialism and territorial aggrandisement.

Thus Lasson, one of the leading teachers of modern Germany and a persistent advocate of the virtues and desirability of war, observes ${ }^{2}$ : "To allow a people, and still more a fraction of a people, to decide international

$1 \mathrm{H}$, von Treitschke, Was fordern wir von Frankreich? (Berlin, 1870). An English translation of this pamphlet is included in a volume entitled Germany, France, Russia, and Islam (London, 1915); p. 163 (reference to the English edition).

2 A. Lasson, Das Culturideal und der K'rieg (Berlin, I868). 
questions, for example, which State shall control them, is as good as making the children of a house vote for their father. It is the most ridiculous fallacy that human wit has ever conceived." It may be said, on the contrary, that this comparison involves a most ridiculous fallacy. To ask the inhabitants of a given territory to decide its fate is to ask them to vote for themselves ; for they are more directly concerned than the sovereign whose subjects they were originally.

Von Sybel, one of the most eminent historians of Germany, writing in $1870,{ }^{1}$ says that a cession of territory is the natural conclusion of a war in which one side is victorious and the other defeated; the defeated party is a debtor of a particular kind who cannot pay his debt except by abandoning a portion of his territory ; there is no longer any diplomacy, or politics, or history, if it be claimed that the payment of this debt should be subordinated to the vote of a province. In reply to this pronouncement, one may say that it rests on the fallacious basis that a defeated country necessarily becomes indebted to the victor. What if the victorious sovereign was an ambitious, unscrupulous aggressor, and the defeated country - comparatively small, powerless, and helpless - is the object of the former's covetousness, and is attacked without any provocation and without any legitimate reason? In what sense, then, can it be said that the small, innocent country overrun and crushed by its powerful, merciless neighbour becomes indebted to it? To argue thus is indeed to resort to such a "transvaluation of values" as will make the worse appear the better reason, and will call black white and evil good.

Treitschke, in the course of a speech made in the

${ }^{1} \mathrm{H}$. von Sybel, Deutschlands Rechte auf Elsass und Lothringen (Leipzig, I871). 
Reichstag in I87I, acclaimed Germany's refusal to entertain the proposal of a plebiscite. "With sound German pride," he said, "we have despised the Bonapartist jugglery of universal suffrage." " Similarly, Herr Wagner, a professor of Göttingen, in a pamphlet published in I870, calls the universal vote a "comedy." "

Schemes for neutralisation and plebiscite having been rejected by the mass of German opinion and by

Division of the German Government, it followed that the territory Alsace-Lorraine was to become part of the suggested. Empire. To effect this object it was suggested in some quarters in Germany that the acquired territory should be divided between the Kingdom of Bavaria and the Grand Duchy of Baden; and the question was raised, too, in the Bundesrat. It may be recalled that after the Preliminaries of Versailles were signed by the representatives of Bavaria, Würtemberg, and Baden, Bismarck is said to have declared that " in order to efface any unpleasant recollections of the war of I866, he intended to hand over to Bavaria the town of Weissenburg after the annexation of Alsace." "These tidings," observes M. Jules Jolly, in his Recollections (he was the representative of Baden, at the Versailles negotiations) "had been welcomed with lively emotion by Count von Bray, the Bavarian minister.'”,

Such distribution of Alsatian territory was afterwards objected to. Treitschke opposed not only the suggested partition of Alsace-Lorraine between Bavaria and Baden, but also the assignment of the territory entirely either to the one State or to the other-as

1 Germany, France, Russia, and Islam, p. I94.

2 A. Wagner, Elsass und Lothringen und ihre Wiedergewinnung für Deutschland (Leipzig, 1870).

3 Cf. Ottokar Lorenz, Kaiser Wilhelm und die Begründung des Reichs, 1866-71 (Jena, 1902), p. 525. 
both these alternatives had also been brought forward ; and he proposed that the provinces should be given to Prussia. He said it was unreasonable to entrust this " outwork of Germany" to a secondary State, and doubted whether German boundaries would be safe in Bavarian hands, and whether Bavaria possessed the intellectual and political power necessary for fusing Alsace into union with herself. ${ }^{1}$ Rather, a common diplomacy and a collective German parliament were best fitted for the work of assimilation. Prussia, however, might be an efficient master. "Prussia alone," he said, "can undertake the remorseless sweeping away of the French officials in Alsace, which is indispensable, and replace the foreign powers by vigorous home ones. Prussia alone can steadfastly maintain the state of siege which, we may easily imagine, may be necessary for a time in some of the districts of the forlorn land. . . . A powerful State, which has impressed its spirit on the inhabitants of the Rhine country and the people of Posen, will know how to reconcile the separate life of the half-French Germans." " "The people of Alsace have learned to despise this Germany, broken into fragments. They will learn to love us when the strong hand of Prussia has educated them." : But against this suggestion many objections were raised; moreover, the Prussian monarch had declared in September 1870 that he desired no increase of territory.

A more liberal proposal was advanced in some quarters, viz. that the acquired provinces should constitute a new autonomous State within Autonomy the German Empire. The German Govern- suggested. ment, however, was not disposed to adopt such a liberal and generous course. In a speech in the
1 op. cit., pp. 163-6.
2 Op. cit., pp. I67, 168.
3 op. cit., p. 173. 
Reichstag, Treitschke argued against the multiplication of small German States: "We have been contending vigorously, gentlemen, during many years for the unity of Germany ; we have seen, in the course of this century, hundreds of small German States collapse; we are now prepared, as men of good feeling, to respect and to spare the few States which remain, because they are no longer in a condition to be exactly injurious to the might of the German Empire. But to create a new State in addition to the already too great existing number, now when we are hard at work counteracting the German tendency to division, to form afresh a State out of the departments which never in the course of their history were a State, to cultivate a new half-German provincialism on the severely endangered frontier-that, gentlemen, I call striking our own face." '

Eventually it was decided to make Alsace-Lorraine simply an imperial province--a Reichsland-to be Alsace- the collective property of all the German Lorraine
made a States; for its dismemberment and division Reichsland. between two or more or its assignment to one of the States would have aroused jealousy and dissatisfaction in the others, and so might have imperilled the stability of the newly established confederation. It thus becomes - to use the words of a recent writer already referred to ${ }^{2-}$ - "la première colonie de la Confédération germanique," or a kind of dependency placed under the sovereign control of the Empire and administered by organs of imperial government acting independently of each and all of the federated States as such. ${ }^{3}$ The federal constitution did not apply $e x$

1 op. cit., pp. 1 88-9.

2 Wetterlé, op. cit., p. 103.

3 Cf. A. Haenel, Dettsches Staatsrecht (IS92, etc.), vol. i. P. 124; Anschütz, in F. von Holtzendorff-Vietmansdorf (Ed. J. Kohler), Enzyclopädie der Rerhtswissenschaft (München; Leipzig, 1913-14), 5 vols. vol. ii. p. 559. 
proprio vigore to the annexed provinces; only express imperial legislation could make it applicable thereto. ${ }^{1}$ The three main reasons that impelled the German Government to impose this status on AlsaceLorraine were, first, the difficulty of satisfactorily fitting conquered territory into a federation of autonomous States, secondly, the danger of a subsequent French invasion in the hope of recovering it, and thirdly, the danger of internal disorder due to the discontentment and alienation of the inhabitants whose territory was annexed without consulting them.

In his speech before the Reichstag, May 25, I87I, Bismarck referred to what were deemed to be the only two practicable courses, viz. to unite Alsace-Lorraine to Prussia, or to constitute it an "immediate territory" of the Empire. He thought from the first that the second alternative was preferable, because dynastic questions would not then become mixed with political questions, and because the Alsatians would more easily assimilate to themselves the name of Germans than that of Prussians-in France it was the Prussians, not so much the Germans, who had been the detested people.

As to how Germany would assimilate the conquered country and make the population loyal Germans the Chancellor had early made up his mind. Bismarck's It is related that when he was asked in I870 $\begin{gathered}\text { view as to } \\ \text { German }\end{gathered}$ at Versailles by one William Jones, an English assimilation. quaker, how the denationalisation of Alsace would be accomplished, he replied that the children would be brought up in German schools, and the younger generation would be subjected to the discipline of the

1 As to the status of the Reichsland and the régime introduced therein, see infra, chap. ix. 
great German army. ${ }^{1}$ In his speech of May 2, I87 I, in the Reichstag, he went into this difficult question a little more fully. He referred to the antipathy of the population to their being taken over by Germany : "This antipathy exists, it is a fact, and it is our duty to overcome it by dint of patience. ... We Germans are in the habit generally of governing with more goodnature, sometimes with a little clumsiness, but on the whole we are more benevolent, more human than French statesmen; this superiority of the German régime will soon reveal itself and seduce the German hearts of the Alsatians. . . Besides, we are able to grant the inhabitants communal and individual liberty, self-government, infinitely greater than they enjoyed under French institutions and traditions. . . . Thanks to German patience and benevolence, we shall succeed in gaining over the population, and that perhaps in less time than may be thought at present." With regard to the ways and means of beginning this task, he pointed out that only a provisional arrangement was then possible, that only empirical methods could in the circumstances be adopted: for the situation was an abnormal one, in that the territory was acquired by conquest, and was made the common property of a Confederation of sovereign princes and free townsa fact, indeed, that was very rare in history, if not unparalleled. Two years later (May I6, I873) the Chancellor again spoke in the Reichstag of the work of assimilation and absorption. He emphasised that it was necessary to combat in Alsace the prevailing sympathies for a past that gave the inhabitants many advantages and many glories, that it was incumbent on the Imperial Government to recognise the truly French sympathies of the country and to overcome

$1 \mathrm{H}$. Welschinger, Bismarck (Paris, I900), p. 130. 
them, despite the difficulty of the task, and above all to act in such a way as not to compromise the material security of Germany.

That Bismarck fully appreciated the difficulties involved and foresaw the troubles that would follow this forcible, arbitrary, and factitious annexa- His doubts tion is evident from such reported conversa- about Metz. tions as the following (on the day following the capitulation of Paris) : "As you see, we are keeping Metz ; but I confess I don't like that part of the arrangement. Strassburg is German in speech, and will be so in heart ten years hence. Metz, however, is French, and will be a hotbed of dissatisfaction for a long time to come. The Emperor has too many foreigners for subjects as it is. We have had more than enough trouble with our Poles, though they have been benevolently governed, God knows! And we shall have still more with these Lorrainers, who hate us like poison and will have, very likely, to be roughly handled, whereas the good old German Elsässer will be treated with the utmost consideration. They will soon like us better than they ever liked the Frenchmen, who were never weary of poking fun at them, gibing at their accent and generally holding them up to ridicule." 1

We shall see in subsequent chapters to what extent the German task succeeded, and how far the attempted assimilation and absorption failed." In the meantime it is necessary to refer to the public protests against the annexation made by the representatives of Alsace-Lorraine in the National Assembly and by other notable deputies.

1 Conversations with Prince Bismarck. Collected by $\mathrm{H}$. von Poschinger. Edited by S. Whitman (London and New York, I900; p. 98).

2 See infra, chaps. ix and $\mathrm{x}$. 


\section{CHAPTER VI}

\section{THE PROTESTS OF I87 I AGAINST THE ANNEXATION}

Declaration of Alsace-Lorraine deputies-Submitted to the National Assembly-Various other protests-Debates in the Assembly on the proposed cession-Vote on the Preliminaries-Further protest of AlsaceLorraine deputies-Demand from Germany-Effects of the annexation.

Thou hast consulted shame to thy house by cutting off many people, and hast sinned against thy soul.

For the stone shall cry out of the wall and the beam out of the timber shall answer it.

Hab. ii. IO, I I

AFTER the three weeks' armistice was concluded on January 28, I87 I, the National Assembly was elected, Protest of and met at Bordeaux (February 12) for the Alsace- purpose of deciding on the continuance or
Lorraine Lorraine
deputies in definitive cessation of hostilities, in view of 1871. the German demands as to the payment of an enormous indemnity and the cession of AlsaceLorraine.

On February I7, after the speech of M. Jules Grévy, who thanked the Assembly for the honour of electing him its President, M. Emile Keller, the head of the list of deputies for the department of the Upper Rhine, dressed in his officer's uniform, which was worn and dusty, read the celebrated declaration of protest against the proposed annexation of Alsace-Lorraine to Germany." Before he read it, he said: "I am

1 See H. Welschinger, La Protestation de l'Alsace-Lorraine les I 7 février et ier mars 1871 a Bordeaux (Paris, 1914), to which indebtedness for various particulars is acknowledged. Cf. also the same writer's La Guerre de 1870 : causes et responsabilités (Paris, 1910). 


\section{THE PROTESTS OF I 87 I}

convinced that the proposition I am about to lay before you will receive your unanimous approval, for our honour and our national unity are at stake: on this point there can be no difference of opinion in a French assembly."

The solemn declaration, signed by all the representatives of Alsace-Lorraine (the departments of the Lower Rhine, Upper Rhine, Moselle, and Meurthe), has now become a noteworthy historical document; so that it may be given here both in the original ${ }^{1}$ and in an English translation:

" We, the undersigned French citizens, elected by the constituen s of the departments of the Lower Rhine, the Upper Rhine, the Meurthe and the Vosges, and chosen by them to bring to the National Assembly of France the unanimous expression of the wish and will of the populations of Alsace and Lorraine, having previously met for and deliberated on the subject,

1 “I. L'Alsace et la Lorraine ne veulent pas être aliénées.

"Associées depuis plus de deux siècles à la France, dans la bonne comme dans la mauvaise fortune, ces deux provinces, sans cesse exposées aux coups de l'ennemi, se sont constamment sacrifiées pour la grandeur nationale; elles ont scellé de leur sang l'indissoluble pacte qui les rattache à l'unité française. Mises aujourd'hui en question par les prétentions étrangères, elles affirment à travers les obstacles et tous les dangers, sous le joug même de l'envahisseur, leur inébranlable fidélité.

"Tous unanimes, les citoyens demeurés dans leurs foyers, comme les soldats accourus sous les drapeaux, les uns en votant, les autres en combattant, signifient à l'Allemagne et au monde l'immuable volonté de l'Alsace et de la Lorraine de rester françaises.

"II. La France ne peut consentir ni signer la cession de la Lorraine et de l'Alsace. Elle ne peut pas, sans mettre en péril la continuité de son existence nationale, porter elle-même un coup mortel à sa propre unité en abandonnant ceux qui ont conquis, par deux cents ans de dévouement patriotique, le droit d'être défendus par le pays tout entier contre les entreprises de la force victorieuse.

"Une assemblée, même issue du suffrage universel, ne pourrait invoquer sa souveraineté, pour couvrir ou ratifier des exigences destructives de l'intégrité nationale. Elle s'arrogerait un droit qui n'appartient même pas au peuple réuni dans ses comices.

“Un pareil excès de pouvoir, qui aurait pour effet de mutiler la mère 
have resolved to set forth in a solemn declaration our sacred and inalienable right, so that the National Assembly, France, and Europe, who have before their eyes the wishes, the will, and the resolutions of our constituents, may not take, or allow to be taken for granted, an act of a nature to injure the rights of which a formal mandate has confided to us the guardianship and the defence.

"I. Alsace and Lorraine refuse to be transferred.

"Associated with France for more than two centuries, in good as in evil fortune, and unceasingly exposed to the blows of the enemy, these two provinces have

commune, dénoncerait aux justes sévérites de l'histoire ceux qui s'en rendraient coupables.

"La France peut subir les coups de la force, elle ne peut sanctionner ses arrêts.

"III. L'Europe ne peut permettre ni ratifier l'abandon de l'Alsace et de la Lorraine.

"Gardiennes des règles de la justice et du droit des gens, les nations civilisées ne sauraient rester plus longtemps insensibles au sort de leurs voisins, sous peine d'être à leur tour victimes des attentats qu'elles auraient tolérés. L'Europe moderne ne peut laisser saisir un peuple comme un vil troupean; elle ne peut rester sourde aux protestations répétées des populations menacées; elle doit à sa propre conservation d'interdire de pareils abus de la force. Elle sait d'ailleurs que l'unité de la France est aujourd'hui, comme dans le passé, une garantie de l'ordre général du monde, une barrière contre l'esprit de conquête et d'invasion.

"La paix, faite au prix d'une cession de territoire, ne serait qu'une trêve ruineuse et non une paix définitive. Elle serait pour tous une cause d'agitation intestine, une provocation légitime et permanente à la guerre. Et quant à nous, Alsaciens et Lorrains, nous serions prêts à recommencer la guerre aujourd'hui, demain, à toute heure, à tout instant.

"En résumé, l'Alsace et la Lorraine protestent hautement contre toute cession. La France ne peut la consentir; l'Europe ne peut la sanctionner.

"En foi de quoi nous prenons nos concitoyens de France, les gouvernements et les peuples du monde entier à temoin que nous tenons d'avance pour nuls et non avenus tous actes et traités, votes ou plébiscite, qui consentiraient abandon en faveur de l'étranger de tout ou partie de nos provinces de l'Alsace et de la Lorraine.

" Nous proclamons par les présentes à jamais inviolable le droit des Alsaciens et des Lorrains de rester membres de la nation française, et nous jurons, tant pour nous que pour nos commettants, nos enfants et leurs descendants, de le revendiquer éternellement, et par toutes les voies, envers et contre tous usurpateurs." 
constantly sacrificed themselves for the national greatness; they have sealed with their blood the indissoluble ties that bind them to French unity. Being challenged by foreign pretensions, they affirm their unswerving loyalty in the face of all obstacles and dangers, under the very yoke of the invader.

"The citizens who have remained at home and the soldiers who have joined the colours unanimously proclaim - the former by their votes, the latter by fighting - to Germany and to the world the unalterable determination of Alsace and Lorraine to remain French.

"II. France may neither consent to nor sign the cession of Lorraine and Alsace. She cannot, without imperilling the continuance of her national existence, herself strike a mortal blow at her own unity, by abandoning those who have acquired by two hundred years of patriotic devotion the right to be defended by the entire country against the aggression of victorious force.

"An Assembly, even though elected by universal suffrage, cannot invoke its sovereignty to sanction or ratify demands that are destructive of the national integrity. It would be arrogating to itself a right which does not belong even to the people themselves assembled to vote under a plebiscite.

"Such an excess of power, which would result in the mutilation of the mother-country common to both of them, would expose to the just condemnation of history those responsible for it.

"France may suffer the blows of violence, she cannot sanction its decrees.

"III. Europe may not permit or ratify the abandonment of Alsace and Lorraine.

"Guardians of the law of justice and of the rights 
of peoples, the civilised nations can no longer remain insensible to the fate of their neighbours, under pain of becoming in their turn victims of the outrages they have tolerated. Modern Europe cannot allow a people to be seized like a herd of cattle ; she cannot remain deaf to the repeated protests of the menaced populations. She owes it to her own preservation to forbid such abuses of force. She knows, moreover, that the unity of France is now, as in the past, a guarantee of the general order of the world, a barrier against the spirit of conquest and invasion.

" Peace concluded at the price of a cession of territory would be only a disastrous truce and not a definitive peace. It would be for all a cause of internal unrest, a legitimate and permanent provocation for war. And as for us, Alsatians and Lorrainers, we would be ready to make war again to-day, to-morrow, at any hour, at any moment.

"Finally, Alsace and Lorraine protest aloud against any cession. France may not consent to it ; Europe may not sanction it.

"In faith whereof we take to witness our fellowcitizens of France, and the governments and nations of the world, that we consider in advance as null and void all acts and treaties, votes or plebiscite, which consent to the abandonment, in favour of a foreign country, of all or part of our provinces of Alsace and Lorraine.

"We proclaim by this act that the right of the Alsatians and Lorrainers to remain members of the French nation shall ever remain inviolable, and we swear, on our own behalf as well as for our constituents, our children and their descendants, always to claim this right, by every means, against all usurpers."

Having read this declaration, M. Keller submitted 
it to the Assembly for its earnest consideration, and reminded it of the painful situation of the provinces due on the one hand to their great suffer- Declaration ings in the war, and on the other to the submitted to menaced alienation from their mother-country. Assembly. His last words, as M. Welschinger aptly remarks, were at once a cry of anguish and a cry of hope : "Behold, gentlemen, we are like the sailor who has let his vessel be sunk rather than surrender his flag. We stretch out our hands to you, do not refuse us yours! " 1

These words brought tears into many eyes; but $M$. Thiers, whilst sharing the feelings of Keller, reminded the members of the Assembly of the urgent exigencies of the situation, that it was incumbent upon them to act as practical, serious men of affairs, and to make up their minds whether the peace negotiators were to be armed with full powers or not-for the one question to be determined upon was peace or war. After the sitting had been suspended for a short time, the following resolution was carried: " The National Assembly, welcoming with the profoundest sympathy the declaration of M. Keller and his colleagues, places its confidence in the wisdom and patriotism of its negotiators." Then M. Thiers was elected head of the executive.

We have already referred to the peace negotiations at Versailles which led to the conclusion of the Preliminaries on February 26, I87r. Whilst these negotiations were in progress the various groups of the National Assembly met to

Various other consider the course they should adopt. The extreme left was for continuing the war rather than submit to the humiliating terms demanded by the enemy. On

\footnotetext{
1 “Tenez, messieurs, nous sommes comme le marin qui a vu couler son navire plutôt que de rendre son drapeau; nous vous tendons la main, ne nous refusez pas la vôtre!"
} 
February I 8 the party assembled under the presidency of Victor Hugo, and adopted an address, drawn up by Louis Blanc, which was delivered to the deputies of Alsace-Lorraine. It declared that neither the National Assembly nor the entire French nation had the right to make even a single Alsatian or Lorrainer a subject of Prussia ; it held in advance null and void every vote or plebiscite whereby any portion of Alsace or of Lorraine should be ceded; it affirmed that, whatever might happen, the citizens of those territories remained the countrymen and brothers of the French people; and it promised them, on behalf of the Republic " an eternal vindication." " This address was signed by thirty-eight deputies, including Victor Hugo, Louis Blanc, Edgar Quinet, and Clemenceau.

On February $28 \mathrm{M}$. Thiers submitted to the Assembly the Preliminaries of Versailles; and at the next day's Debates in sitting, under the presidency of M. Grévy, Assembly
on proposed the terms of peace were discussed. As soon cession. as the proceedings commenced, one member rose to make a protest against all eventual cession of territory; another demanded that the inhabitants of the provinces in question should be consulted; a third denied the right to cede any territory at all; a fourth handed his resignation to the President, saying that he could not be a party to the discussion of territorial cession ; and so on. In reply it was pointed out that the enemy was inexorable, and that it was an urgent necessity to arrest the invasion; if the Assembly chose to renew the conflict by refusing to ratify the Preliminaries, Paris would be occupied, the invasion of France extended, and Heaven knew what further disasters might follow; the Assembly was therefore urged not to abandon itself to a policy of desperation. 
Edgar Quinet said that till then the conquest had been only depredation, but if it were ratified by the Assembly it would assume the character of a right; Prussia wanted France to commit suicide, by means of a vote of the Assembly; Alsace and Lorraine were not only two French provinces, they were also bulwarks of France. Victor Hugo vowed that Alsace and Lorraine would remain French whatever might happen, and that France would never abandon her right and duty in regard to the provinces. "Non, la France ne périra pas, quelle que soit la lâcheté de l'Europe. Dès demain, la France n'aura plus qu'une pensée: se reconstituer, reprendre ses forces, ramasser son énergie, nourrir de saintes colères, élever sa génération; ses petits deviendront grands; former une armée qui sera un peuple tout entier, travailler sans relâche, étudier les procédés et la science de nos ennemis, redevenir la grande France, la France de I792, la France de l'idée et de l'épée . . . Et puis un jour elle se dressera invincible." 1 He ended his speech on a humanitarian note, predicting a fraternal reconciliation: " France, one day victorious, would raise defeated Germany and say to her that they were sisters, and ought to act together as a single people, a single family, a single Republic." Louis Blanc said that history would ask Europe why she remained silent in the face of Prussian proceedings, the enormity of which exceeded all bounds. What could one expect of Prussia, who began with the robbery of Silesia and the partitioning of Poland? Did not Russia see the German imperial eagle stretching its wings over the Baltic? Had Austria forgotten Sadowa? Did not Italy see the eye of Prussia on Trieste? Had not the fate of Denmark warned Holland? Did not England understand the designs

\footnotetext{
1 Cf. Villefort, op. cit., vol. ii., p. 49.
} 
of Pan-Germanism? Was it so long ago that in the interests of European equilibrium Belgium was placed under protection from invasion?

Once more Keller appealed to the Assembly not to deliver up Alsace-Lorraine; and he repudiated the treaty, which was for him a lie. "We wish to remain French," he said, " and we shall remain French; no power in the world, no signature, either of the Assembly or of Prussia, can prevent us from remaining French. ... Is it honourable to abandon populations who wish to remain French, and who, despite all, will remain French? . . . This treaty, which it is proposed to ratify, is an injustice and at the same time a lie. . . . Before leaving this place I am bound to protest, as an Alsatian and as a Frenchman, against a treaty which is, in my eyes, an injustice, a lie, and a dishonour; and, if the Assembly should ratify it, I appeal to God, the avenger of just causes; I appeal to posterity, which will judge us one and all ; I appeal to all peoples, who cannot let themselves be sold like a wretched herd of cattle; I appeal finally to the sword of men of mettle who will at the earliest possible moment tear up this detestable treaty!" 1 Here Thiers exclaimed to Keller: "Give us means, not words." Keller did not reply, but another member, M. Tirard, got up and cried: "Levy en masse! You ask for the means. Let the 750 representatives put themselves at the head of France, and you will save France!" To which Thiers replied: " If you think you can get better conditions, send other negotiators, and you will thus take away a great burden from me. If you think you have military resources, produce them." A silence followed. All eyes turned towards General Chanzy, who remained silent. Then Thiers emphasised that France was not in a position to 
go on with the war, and fully explained the whole situation; he impressed upon the Assembly his view that, if France decided to continue the war instead of accepting the terms imposed, she would be ruined and her future would be destroyed. He reminded his auditors that when France was mad enough to declare war in 1870 , she was not prepared for it; hostilities had gone on in a state of military disorganisation from the first; and after the disasters that had been suffered in consequence it was no longer possible to offer successful resistance to the large duly constituted armies of the invader.

A vote was then taken on the Preliminaries; 546 voted for their acceptance, and I07 for their rejection.

Then M. Jules Grosjean read another protest in the name of all his colleagues representing the departments of the Lower Rhine, Upper Rhine, and the Moselle. It was as follows: ${ }^{1}$

"The representatives of Alsace and Lorraine have

1 “ Les représentants de l'Alsace et de la Lorraine ont déposé, avant toute négociation de paix, sur le bureau de l'Assemblée nationale, une déclaration affirmant de la manière la plus formelle, au nom de ces provinces, leur volonté et leur droit de rester françaises.

"Livrés, au mépris de toute justice et par un odieux abus de la force, à la domination de l'étranger, nous avons un dernier devoir à remplir.

"Nous déclarons encore une fois nul et non avenu un pacte qui dispose de nous sans notre consentement.

" La revendication de nos droits reste à jamais ouverte à tous et à chacun dans la forme et dans la mesure que notre conscience nous dictera.

“ Au moment de quitter cette enceinte où notre dignité ne nous permet plus de siéger, et malgré l'amertume de notre douleur, la pensée suprême que nous trouvons au fond de nos cœurs est une pensée de reconnaissance pour ceux qui, pendant six mois, n'ont pas cessé de nous défendre, et d'inaltérable attachement à la patrie dont nous sommes violemment arrachés.

" Nous vous suivrons de nos vœux et nous attendrons, avec une confiance entière dans l'avenir, que la France régénérée reprenne le cours de sa grande destinée.

“Vos frères d'Alsace et de Lorraine, séparés en ce moment de la famille commune, conserveront à la France, absente de leurs foyers, une affection filiale jusqu'au jour où elle viendra y reprendre sa place." 
delivered to the office of the National Assembly, Further before all peace negotiations, a declaration protest of affirming in the most formal manner, in the Lorraine name of these provinces, their will and their deputies. right to remain French.

"Given up, in contempt of all justice and by an odious abuse of force, to foreign domination, we have one last duty to fulfil.

"We declare once more null and void a compact that disposes of us without our consent.

"The vindication of our right remains ever open to all and each of us in such form and measure as our conscience shall dictate.

"At the moment of leaving these precincts where our dignity no longer permits us to remain, and despite the bitterness of our grief, the supreme thought we find in the bottom of our hearts is a thought of gratitude to those who for six months did not cease to protect us, and of unalterable attachment to the mother-country from which we are violently torn.

"We shall follow you with our prayers and we shall wait with perfect confidence in the future, till regenerated France resumes the course of her high destiny.

"Your brothers of Alsace and Lorraine, separated at this moment from the common family, will preserve for France, absent from their hearths, a filial affection until the day when she will come to take her place there again."

"C'était," comments M. Welschinger," "le dernier sanglot des deux provinces arrachées à la France." In vain did the Assembly appeal to the protesting deputies to remain in their places; having thus resigned their positions, they left "sombres et silencieux." " Cette fin de séance eut un aspect funèbre." : 
Several members of the Republican party, notably MM. Rochefort, Ranc, Benoît Malon, Félix Pyat, also sent in their resignations, saying they would not sit a single day longer " in an Assembly that had surrendered two provinces, dismembered France, and ruined the country." '

Such were the scenes-the eloquent speeches, the burning protests, the vows of brotherhood exchanged by those who were to be severed, the sobs of bereaved souls - that were witnessed on that memorable occasion when the representatives of France had thrust upon them for their acceptance the humiliating conditions demanded by an inexorable conqueror. "Will such scenes," observes M. Gabriel Hanotaux, " the lessons which they carry, and the duties which they impose, ever be effaced from the memory of the nation?" "

After the ratification of the Preliminaries of Versailles the protesters saw clearly that the fate of their provinces was sealed; and on March $24 \mathrm{M}$.

Frédéric Hartmann turning towards Germany $\begin{gathered}\text { Demand } \\ \text { from }\end{gathered}$ uttered these words, apt and precise: "By Germany. the fact that you have conquered us you owe us a legal status, a civil and political constitution in harmony with our traditions and our customs." This sentence enshrines the wisest policy-next to that of refraining from forcible annexation-which would in the circumstances have readily commended itself to statesmen possessing clear vision and sympathetic understanding. Whether it was through lack of these qualities or through the overweening arrogance and obstinacy of ungenerous and irate masters, the counsel was disregarded. Thus was perpetuated the Franco-German estrange-

1 For the protests made in the Reichstag in 1874 by the deputies of Alsace. Lorraine see infra, chap. $\mathrm{x}$, in init.

2 Contemporary France, English trans. (London, 1903), vol. i. p. 125. 
ment, which did much to foster Germany's militarism and her resolve to acquire hegemony in Europe, to promote a sinister international diplomacy and intriguing political combinations, and so to prepare the way for the valley of the shadow of death of the present day.

An authoritative German historian, commenting on the fateful European politics consequent on the Effects of the Franco-Prussian War, observes: " From the annexation. very outset the new structure of the German Empire was burdened as it were by a French mortgage, since every foreign foe could henceforth reckon unconditionally on French support. As in the past Frederick the Great had had to vindicate his conquest of Silesia in a seven years' war against a European combination, so Bismarck in his turn was painfully aware that the menace of a coalition hourly weighed upon his new creation. The great aim of his policy, from the first, was to prevent the formation of any such coalition." 1

It appears that Bismarck himself admitted, a few years after the war, that the dismemberment of France was a blunder. In a despatch addressed to the French Minister for Foreign Affairs, November I4, I879, M. de Saint-Vallier, the French ambassador at Berlin, reported a conversation he had with the German Chancellor. The latter is stated to have expressed himself to this effect: "One destroys a nation if one's power permits it, or if one's interest demands it ; one does not mutilate it with impunity . . . and history, the great instructor of statesmen, teaches us that one has always to repent it. In mutilating and humiliating Prussia, Napoleon caused the Steins and the Scharnhorsts to arise; in taking from you Metz and part of Lorraine, the

1 Professor Hermann Oncken, in Cambridge Modern History (Cambridge, I910), vol. xii. p. 136. 


\section{THE PROTESTS OF I87I}

Emperor, my master, and the militarists who inspired this resolve committed the greatest of political mistakes."'

In the light of an admission of this kind, and in view of the disastrous effects produced by a factitious and irrational dismemberment, we have now to examine the claims to Alsace-Lorraine that have been made from time to time in Germany, and the alleged grounds of its annexation.

1 Nothing seems to have been said of Alsace, according to this reported conversation 


\title{
CHAPTER VII
}

\author{
GERMAN CLAIMS TO ALSACE - LORRAINE - ALLEGED \\ GROUNDS OF ANNEXATION : (a) HISTORICAL \\ GROUNDS; NATIONALITY AND RACE; LANGUAGE
}

Historical grounds: Ranke's view-Mommsen's view-Treitschke's viewEarly treaties-Appeal to the Holy Roman Empire-Difficulties in such contentions. Racial grounds: Names as a criterion-Claim untenable-Treitschke's arrogant pretensions. Claim on ground of language: Early struggles between languages-German dialect becomes predominant-Position of the pays messin. Principle of nationalityAttachment of Alsace to France-Principle of public right.

THE claims to Alsace-Lorraine laid by Germany are based on various grounds, e.g. historical considerations and previous ownership, nationality and race German
claims to language, political necessity and German Alsace- unity, military necessity and security, and Lorraine. finally (after I870) the right of conquest. Before 1870 these claims were advanced on several noteworthy occasions. Thus during the Napoleonic wars, they were made by Prussian patriots in $18 \mathrm{I} 3$ and I8I5, when the Allied armies had penetrated into France. During the peace negotiations in the latter year the demand of the King of Prussia that France should be so dismembered was objected to by the Tsar, and the objection was acquiesced in. Prussia, however, did her utmost to maintain the anti-French movement, which had before been set on foot in Europe in consequence of the Revolutionary and Napoleonic régimes. Her writers and professors began to be more insistent on the pretension that Alsace and 
Lorraine were really part of Germany and ought legitimately to be under German dominion. The claim was repeated in I840, when Europe was nearly dragged into a general conflict as a result of the ambitious enterprise of the astute Mehemet Ali ; and it was reiterated in 1859 when Prussia was on the point of intervening in the conflict between France and Austria. Till I866, France laughed at those demands ; but in 1867 , when the Luxemburg affair aroused Prussian public opinion with regard to Alsace-Lorraine, she realised that the position was becoming serious. On the declaration of war in I870 it was generally felt that the integrity of French territory was at stake. AlsaceLorraine, well aware of the franzosen-fresserei of Germans and of their repeated demands, saw clearly that its destiny was now in question; and only a few months after the outbreak of the war it realised that its fate was sealed.

Let us consider one by one the German claims to Alsace-Lorraine and the grounds alleged for the annexation.

In the first place, it was contended that the territory had been part of the German dominions until France got possession of it by force or fraud; so that the claim thereto amounted to no more Claims on than the vindication of an old inalienable grounds. right. Accordingly the Germans long held that its annexation would be a mere restoration-a zurückeroberung (a recapture) as distinguished from an eroberung (a conquest).

This was in the mind of the eminent historian, Leopold von Ranke, when he addressed the following remark to Thiers in the autumn of I870 Ranke's immediately after the fall of Napoleon III : view. "It is against Louis XIV that we have now to wage 
war." "He was thinking of the French act of aggression whereby the provinces were wrested in the seventeenth century from a disunited Germany, and of the latter's necessity to undo that act.

Similarly, in 1870 , in a series of letters addressed to the people of Italy, which were published in Milanese Mommsen's papers, Mommsen said, speaking of the view. German war aims" : "We ask something more than money. We claim territory; not French territory, but German. . . Melancholy is the tale of our neighbours appropriating Lorraine first, then Alsace. . . The feeble policy of our forefathers betrayed our land, our faith, and our language." He emphasised that it was a question, therefore, of restoration and not of conquest: " Let France keep her French territory intact, whether always hers or not we will not ask. We desire no conquests; we want what is our own, neither more nor less."

Treitschke, writing also in 1870 after the first German successes against France, said : " The thought Treitschke's which, after first knocking timidly at our view. doors as a shamefaced wish, has, in four swift weeks, grown to be the mighty war-cry of the nation, is no other than this: Restore what you stole from us long ago; give back Alsace and Lorraine. . . . Why was it that, before the declaration of the war, the anxious cry rang through Alsace and Lorraine, "The dice were to be thrown to settle the destiny of our provinces,' before a single German newspaper had

1 For a somewhat different interpretation of Ranke's words see infra, p. 139 .

2 Letters on the IVar between Germany and France (London, I871). Letters I, II, and III, by T. Mommsen; No. I published in the Milanese paper, $L a$ Perseveranza; Nos. II and III in the Milanese paper, Il Secolo (August 20 I 870$)$. The references are to the English translation issued under the above title.

3 Ibid., Pp. 20, 21, 24, 29. 
demanded the restitution of the plunder? Because the awakened conscience of the people felt what penalty would have to be paid in the interests of justice by the disturber of the peace of nations." "This is not the true answer. The true answer is: because it was known that the Germans had long claimed the territory, that they regarded its eventual acquisition as only a restoration, that they did not make war for the vindication of honour and equitable reparation, but for territorial aggrandisement, that they coveted its mineral resources, and finally because Alsace-Lorraine was the most convenient French territory that could be annexed for geographical and commercial reasons.

Other claimants alleging these grounds are not so modest from an historical point of view. They refer even to such an ancient transaction as the Early Treaty of Verdun, A.D. 843 , to show that treaties. Germany should extend to the Meuse. But as Germany then consisted of a great number of small States, and there was no consciousness of national unity whatever, it is a far-fetched and absurd contention for modern Germans to advance that the territories concerned formerly constituted part of the German " fatherland " ; at an early date like this a German " fatherland " was not in existence, and it is a distortion of historical perspective to speak of it as such. Nor can we, on behalf of France, invoke the treaty of peace and alliance contracted at Vaucouleurs between Albert, King of the Romans, and Philip the Fair, whereby the former, with the concurrence of the prelates and nobles of Germany, agreed that the boundaries of France should be extended from the Meuse to the Rhine. ${ }^{2}$

1 Germany, France, Russia, and Islam (London, 19I5), pp. 99, IoO.

2 This treaty is reported by the fourteenth-century chronicler, Guillaume de Nangis; modern edition by H. Géraud (Paris, I $8_{4} 3$ ), vol. i. p. 308. 
The extravagant character and inadmissibility of the appeal to the Holy Roman Empire made by Appeal to German writers become self-evident when Holy Roman we look at the constitution of this Empire. Empire. It was not a State in the modern sense of the term ; it was an artificial and precarious Confederation that was held together with extreme looseness. It comprised the following: Central Europe ; the United Provinces (Holland); the territories including the modern Luxemburg and the greater part of modern Belgium ; about a third of modern France, including in the north (under Charles V) Flanders and Artois, in the north-east the territory between the Rhine and the Meuse (i.e. Alsace-Lorraine, etc.), in the east the Franche Comté and a part of Burgundy, in the southeast the territory between the Alps and the Rhône (viz. Provence, Dauphiné, Savoy, and Lyonnais) ; Switzerland ; north and central Italy as far as Naples. This heterogeneous conglomeration of races, peoples, nationalities, kingdoms, duchies, countships, bishoprics, republics, free cities, etc., cannot be said to constitute a "fatherland" or a nation. In the later fifteenth century it contained some four hundred "States" or political units. Conflicts between them were frequent; and frequent were the appeals made by this or that ruler or league of rulers to foreign monarchs, notably to the kings of France and Sweden. In those days, too, national boundaries had not yet become fixed or stable; the feudal régime made impossible the very existence of nations and nationality. To belong to the Empire meant little more than the payment of tribute; it did not defend the weaker constituents from foreign raiders and plunderers. Before Alsace became French it, too, lacked a homogeneous political system; it was a miniature counterpart of 
the Empire itself in that it comprised a large number of dissociated units-bishoprics, free towns, selfgoverning republics, baronies, counties, and hereditary fiefs of the House of Austria. When Alsace became French this political heterogeneity began rapidly to disappear ; and Germany, in the modern sense of the term, was not in existence. Indeed, Alsace was part of France before such French territories as Lille, Nancy, Besançon.

Further, of this Holy Roman Empire-of which Voltaire aptly said that it was not an Empire, nor Roman, nor holy-Austria, and not Germany, was the successor.

In the Middle Ages Alsace, even though attached to this Confederation, sought inspiration from France for her culture, art, literature, architecture, scholarship. " As a fact," observes a recent Alsace and Alsatian writer," "Alsace, even in the Middle

France. Ages, though it spoke a German dialect, was in the orbit of French culture. The Gothic artists who built Strassburg Cathedral came from the Île de France or had learnt their art there. The Alsatian authors who figure in German literature, such as Gottfried of Strassburg, and Fischart, imitated French authors, or initiated their German readers into the courtly life of France. Alsatian scholars studied in Paris, and at all periods many persons conversant with the French tongue were to be found in the cultivated classes."

However this may be, supposing that historical grounds be taken as the basis for modern territorial claims, the essential question at in hifstorical once arises-What date is to be regarded as contention. the point of departure? If former entities and political

1 P. A. Helmer, Alsace under German Rule (London, 1915), pp. 7, 8; cf. the same author's France-Alsace (Paris, I916), pp. 36-96: "L'Alsace sous le régime allemand." 
attachments are to be re-established, which Europe is to be set up again (asks Fustel de Coulanges ${ }^{1}$ in his effective reply to Mommsen's Letters) - that of the seventeenth century, or of the fifteenth, or that of the more distant epoch when ancient Gaul possessed the whole of the Rhine and when Strassburg, Saverne, and Colmar were Roman towns?

Could the German claim to Alsace on historical grounds be entertained, we should at once be confronted with a number of corollaries that would lead us into a maze of absurdities and impossibilities. If modern Germany is entitled to the possession of Alsace-Lorraine because it formerly belonged to the Holy Roman Empire, then she is equally entitled to the possession of Belgium, Switzerland, Northern France, Northern Italy, etc. Adopting the same reasoning, we should have to conclude that England has a legitimate claim to the United States, that Spain may advance a valid claim to the Spanish-American Republics, and so on ad infinitum.

Next we come to the question of race, kingship, and ethnical nationality, which, of course, does not claims on necessarily coincide, in the case of a given racial on territory, with the question of early historical grounds. association, but which may be, and often is, connected with it. German writers have asserted the claims of their country to Alsace-Lorraine on the ground that the population was of German blood ; the following verse expresses this view :

\footnotetext{
Doch dort an den Vogesen

Liegt ein verlornes Gut;

Dort gilt es deutsches Blut

Vom Höllenjoch $\mathrm{zu}$ lisen.
}

(There, hard by the Vosges, is a lost treasure; there German blood must be delivered from the yoke of hell.)

1 N. Fustel de Coulanges, L'Alsace, est-elle allemande ou française? Réponse d M. Mommsen (Paris, 1870 ), p. 14 . 
It is pointed out that the Germanic origin of Alsatians is shown in the modern names of persons. An American observer" writes thus: "The ori- Names as ginally Germanic character of the people of a criterion. Alsace is plainly shown by the family names. Passing down Rufacherstrasse, a leading street in Colmar, I note these names on the door-plates and signs : Lange, Heilgendorf, Scherrer, Schultz, Weill, Schönbrod, Schaffer, Casper, Roths, Hacker, Didier, Werkemann, Bürger, Spira, Meyer, Pfleger, Wilberger, Klein, Schanzler, Becker, Luttin, Levy, Rueff, Moore, Geegert, Hidgen, Eglensdorfer, Heyne, Schoy, Kayser, Hild, Wertheim, Gerwig, Heimburger, Wyler, Burlen, Albrecht, Schuler, Helmer, Lentz, Blum, Matter, Engasser, Wittersheim.

"In the directory of Mülhausen, the first forty-six names are Aab, Abegy, Abèle, Aberlen, Abermann, Aberth, Abraham, Abrahamsohn, Abry, Abt, Ach, Achenbach, Acker, Ackerer, Ackermann, Adam, Adams, Adelbrecht, Adelhold, Adis, Adler, Adloff, Adehung, Adolph, Adnau, Achen, Aeble, Aeby, Aegister, Aegler, Aeschmann, Agde, Agrippino, Ahr, Ahrens, Aicheler, Aischelmann, Aigle, Aichinger, Aigner, Ailuger, Albanesius, Alber, Albert, Albich, Albinus.

"But two of these (Abèle, Aigle) have a French origin, and one (Adams) is apparently English. Three (Agrippino, Albinesius and Albinus) represent the Teutonised Latin widely spread over Germany in an earlier day. It is worth noting that all the republican or nationalist leaders of Upper Alsace have German names, while in Lorraine, in several cases, German conservatism is marked by names unqualifiedly French."

1 D. S. Jordan, Alsace-Lorraine: A Study in Conquest, I9I3 (Indianopolis, I917), pp. $36-8$. 
However this may be, from the character of names and from ethnical considerations generally it is possible to draw quite different conclusions. In regard to names there is undoubtedly a tendency for the conquered, subject, or alien inhabitants of a country to assume such names or so modify their own names as to make them similar or akin to those of the conquerors or of the native population as the case may be. One wellknown instance will suffice as an illustration, viz. the case of the Jews : in England their names are frequently anglicised; in Germany they are often germanised; in Russia they are russified, and so on ; and yet they are all of the same race. Julius Cæsar says he found the territories that are now Alsace-Lorraine inhabited by Gauls ; the German invasions afterwards introduced another racial element; and a certain fusion between them was also effected. The Celtic type, in fact, subsists in Alsace; and in Lorraine it appears to predominate; the presence of the Germanic type does not prove that the country is German. If this were so, we might argue that because the Goths left considerable Germanic traces in Spain when they invaded the country many centuries ago, therefore Spain is to be regarded as more or less germanised, and hence the modern Germans are entitled to lay claim to the parts of Spain thus affected. That the racial criterion cannot be adopted to support claims to territorial proprietorship or dominion is clearly shown by such examples as Belgium, with her Flemish and Walloon elements, and Switzerland, with her different ethnical constituents. If race is to be the determining factor, then Portugal should be absorbed by Spain, Scotland should be separated from England, Posen from Germany, Livonia and Riga from Russia, and so on.

We may apply, too, in regard to the racial claim 
an argument similar to that we have already applied in reference to the historical claim, and effect in the former case, as in the latter, a reductio ad absurdum. Thus, Alsace was predomi-

Difficulties in racial claims. nantly German before it became largely French; but it was Celtic or Gallic before it became predominantly German; before the Celtic inhabitants there were the prehistoric aborigines; and before the latter there were - presumably-apes. It is in view of such a resulting absurdity that Renan writes: "Avec la philosophie de l'histoire telle que la pratiquent les Allemands il n'y a de légitime de par le monde que le droit des orangsoutangs injustement dépossédés par la perfidie des civilisés."

Though the Germans long claimed that AlsaceLorraine was really a German country, and that the greater part of its population was of true German blood, yet when they "recovered" German their "lost brothers" or "lost children" tradiction. they imposed a large number of restrictions on them, and throughout denied their province the legal status of a German State on the ground that it was not German enough. There is thus the contradiction that AlsaceLorraine was, on the one hand, wrenched from France because it was alleged to be overwhelmingly German, and was, on the other hand, refused equal treatment

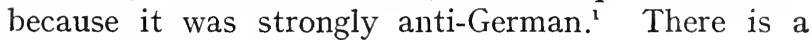
further contradiction-the opposition of Germany to a plebiscite before the annexation, and the consent to allow the inhabitants an option as to their allegiance. It would therefore appear that it was not really their " lost brothers" and the long-lamented German blood that the Germans had sought to recover, but their country and its resources. Treitschke, however, has

1 Cf. Novicow, op. cit., p. I89. 
his reply ready in defence of the annexationist policya reply inspired by arrogance and impaired by inconsistency and confusion of thought.

"In view of our obligation to secure the peace of the world," he exclaims, "who will venture to object Treitschke's that the people of Alsace and Lorraine do arrogant
and unten not want to belong to us ? The doctrine of and unten-
able pretensions. race to decide on their own destinies, the plausible solution of demagogues without a fatherland, shivers to pieces in presence of the sacred necessity of these great days. These territories are ours by the right of the sword, and we shall dispose of them in virtue of a higher right-the right of the German nation, which will not permit its lost children to remain strangers to the German Empire. ${ }^{1}$ We Germans who know Germany and France, know better than these unfortunates themselves what is good for the people of Alsace, who have remained under the misleading influence of their French connection outside the sympathies of new Germany. Against their will we shall restore them to their true selves. . . . Before the nineteenth century closes the world will recognise that the spirits of Erwin von Steinbach and Sebastian Brandt are still alive, and that we were only obeying the dictates of national honour when we made little account of the preferences of the people who live in Alsace to-day." : The subsequent history of the provinces under the German régime shows (as we shall see later on ${ }^{3}$ ) that these high claims and confident predictions were not fulfilled.

1 Treitschke is said to have admitted soon afterwards that the claim in regard to the racial origin of the Alsatians was a mere "swindle"; see infra, p. 138 .

2 Op. cit., pp. 105, 106.

3 See chap. ix, pp. 155 seq. 
With regard to the German claim to Alsace-Lorraine on the ground of language, Mommsen declared ${ }^{1}$ in I 870 that the population of Alsace was purely German, with the exception of a few French Claim on valleys in the Vosges-the latter comprising language. only I20 communes with 30,000 inhabitants, the remaining 917 communes with $\mathrm{I}, 035, \mathrm{IO} 2$ inhabitants speaking German. "One of our most conscientious political economists calculated, before the war, that but a seventh part of the Alsatians understand French ; and again, but a small part of these use this language in domestic life. The country people and peasants universally speak nothing but German. . . . Here in these valleys you hear our songs and our legends; and our literature has formed here a nucleus of opposition against Paris. ..." As to so-called German Lorraine, including part of the department east of the Meurthe and the Moselle and the cantons of Saar, the same writer asserts that until I75I it conducted all its official affairs in German, and it still preserved this language in its private life. "By the account of the French Minister of Instruction, made out in 1865 , in 76 communes of the department of the Meurthe, out of 46,508 inhabitants only 6,870 could speak the French language; whilst among those who attended the schools, in number 6,800 , only 2,400 could be said to speak it correctly. . . The city and canton of Thionville are completely German."

To this much too brief account given by Mommsen we may add the following observations both as a supplement and as a correction:' From the fourth

1 Letters, etc., pp. 24 seq.

2 Cf. C. Pfister, La limite de la langue française et de la langue allemande en Alsace-Lorraine (Paris, I890); G. May, La lutte pour le français en Lorraine avant $1870 .-$ Annales de l'Est publiees par la Faculté des Lettres de l'Université de Nancy (Paris; Nancy, I912). 
century to the middle of the first century B.c. both Early slopes of the Vosges (including the modern

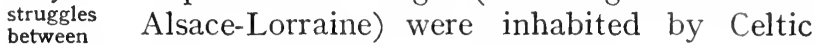
languages. tribes. During the Germanic invasions of the first century B.C. the Triboci established themselves in Lower Alsace among the Mediomatrici, a Celtic tribe. In 72 B.c. the Sequani, another Celtic people, occupying Upper Alsace and the modern Besançon, appealed for aid to the German chieftain, Ariovistus, who took possession of the country of the people he came to help. He was, however, expelled by Cæsar in 58 B.C. ; but the Triboci remained. Thus a Germanic tongue was spoken from the frontiers of Sequania to the Sauer. From A.D. Ioo to the middle of the fourth century Latin predominated. A little later the Germanic language, already spoken in Alsace, was brought into Lorraine by the barbarian soldiers in the Roman service and by barbarian colonists (the Alemanni). The incursions continuing, the Germanic element increased, and began to prevail over the Latin. After the recall of the Roman troops in the fifth century Alsace was invaded by the barbarians, and in the following century Latin almost disappeared from the country-except in one corner of the Vosges, at Orbey, Sainte-Marie-aux-Mines, and Schirmeck, where Latin took the form of a Romance dialect. ${ }^{1}$ In Lorraine the earlier names were replaced by German in the fifth and sixth centuries.

Later, German made progress in Alsace; it predominated in the south near Oberlarg and Lucelle, German and gained in the north in the valley of

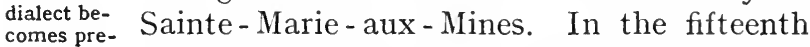
dominant. century, however, French was the principal language in this valley, though in the following 
century the German population increased-on the one hand there were the Saxon immigrants who came to the silver mines, on the other there were Calvinist refugees. Thus from I560 to I789 the Germanic patois supplanted French in these mining districts. In the upper valley of the Bruche a Germanic colony was brought by the Anabaptists of Salm; but in the fourteenth and sixteenth centuries Swiss peoples, taking refuge in the Schirmeck district, reinforced the Romance element. Thus the progress of German, due to the immigrations, was comparatively small. French had gained a little in Lorraine, in the two upper valleys of the Sarre. ${ }^{1}$ Its slow progress in Alsace was due to the neglect of Louis XIV, who, though concerned about religious unity, did nothing for extending the teaching of French; not a word of French was taught, says M. Pfister, in the villages of Alsace and German Lorraine before I789." Only the upper classes among the urban populations spoke French, which they acquired in Paris, and not in the universities, which taught in Latin. Writing was done in Gothic, and not in Roman characters. Later, Louis-Philippe introduced French into the schools; and Napoleon III made systematic provision for its use and teaching. Its expansion, however, was hindered by a portion of the clergy, who feared the language of Voltaire, and respected German as the language of the Catechism. Nevertheless, French advanced, especially in the towns; but in I870 it had not generally overtaken German." After that date, as we shall see later, the latter language made further progress under the German régime. Had the annexation been deferred for a time there is no doubt that French would have become the predominating language."

\footnotetext{
1 Pfister, op. cit., p. $39 . \quad 2$ Ibid., p. 40. ${ }^{3}$ Ibid. "May, op. cit., p. 8
} 
In a word, before the union of Alsace to France, the Alsatians, or the greater part of them, spoke German, which continued after the union to be the predominating language of the province. Before the union of the Duchy of Lorraine to France the greater part of its population spoke French; but in about a third of the territory, known as German Lorraine, very little French was spoken. After France acquired the Duchy the Germanic dialect continued to be used in German Lorraine in families, in business relationships, in schools and in religious services, but not for official purposes. Two points are here to be noted: first, German Lorraine would, till I 870 , have been more appropriately described as German-speaking Lorraine, for the use of the language did not necessarily make the people German in thought, feeling, or usages; secondly, their language (like that of Alsace) was not the classical German, but a Germanic patois.

Moreover, in I87I, Germany annexed not only Alsace and German-speaking Lorraine, but also a Position of considerable portion of French-speaking

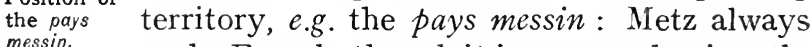
messin.

\section{German.} spoke French, though it is now predominantly

Mommsen admitted that to take this town from France could not be defended on the ground of language, sentiment, etc. "In possessing ourselves of Metz," he writes, "there will be a difficulty, as every one will see, in taking a French province, however small, ruled by French laws and sentiments, and making it German; and public opinion, when it classes Metz with Alsace and German Lorraine, I think makes a mistake." 1

From the above exposition of the language question, it can by no means be inferred that the use of a par- 
ticular language in a certain locality is either a valid criterion for determining nationality in the proper significance of the term (not merely in its ethnical sense), or an admissible basis for founding territorial claims. In the first place,

Language as a criterion. the argument as to priority is here also applicable : from what date are we to start in asserting the predominance of this or that language in a given country ? Secondly, if Germany might claim Alsace-Lorraine in I870, because of the predominance of Germanic dialects in these provinces at that date, then she might just as legitimately have then claimed also (and may claim even now) various other countries or distinct parts of countries where Germanic languages prevail, e.g. Belgium (Flemish), Holland, a large part of Switzerland, Luxemburg and Austria. Similarly, England might claim the United States; and France might demand a great part of Switzerland, of Belgium, and of Canada. The use in a country of a common language no doubt tends to cement the nation; but it certainly cannot be taken as the characteristic test of nationality. That Germany can, when it suits her, disregard historical, racial, and linguistic considerations is shown by the annexation of a part of Poland, which was Slav in race and language.

Nationality, indeed, depends much more on a people's common sentiment, aspirations, ideals, interests, remembrances, and desire for unity Principle of and for a common social life. Intention and nationality. will and actual facts are of far greater consequence than the fortuitous circumstances relating to distant and long-forgotten origins. It is for these vital reasons, and not in virtue of ethnographical and philological conclusions, that men are willing to live together, to fight side by side, to die for each other. The fact that 
the Marseillaise was composed and first sung in Strassburg and stirred the blood of its citizens possesses a greater significance than the fact that in this or that corner of the city a Teutonic dialect was spoken. To wrest a population from a country and a political system to which it is attached by ties of affinity, to which it wishes to remain attached, and thrust it against its will into another country and political system which it regards as alien can never be justified by inferences drawn from a state of things that existed in the past. Human beings are not chattels; no law and no morality, other than those of savages and barbarians, can treat one group of men as the objects of transactions, as the pawns of a game, carried on between other groups of men. The only sense in which the principle of nationality may legitimately apply is where a province or a population refuses obedience to a foreign pretender; it may not be invoked by a foreign pretender as a ground for forcible annexation. Thus the principle of nationality did not entitle Piedmont to conquer Milan and Venice; but it gave Milan and Venice the right to liberate themselves from Austria and unite themselves voluntarily to Piedmont. "Ce principe," said Fustel de Coulanges in 1870 to Germany, " peut bien donner à l'Alsace un droit; mais il ne vous en donne aucun sur elle. . . . Il constitue un droit pour les faibles; il n'est pas un prétexte pour les ambitieux." " Whatever Germanic elements of race and language Alsace may have possessed, it was for a long time French in its real nationality and its sentiment de patrie.

Even as long ago as I709, at a critical moment for France resulting from the IVar of the Spanish Succession, the Prussian ambassador at the Court of France, 
Baron Schmettau, presented, in the name of his master Frederick I, a memorandum to the plenipotentiaries at the Hague, wherein he declared that the Alsatians weremore French than the Parisians, $\begin{array}{r}\text { Attachment } \\ \text { of Alsace }\end{array}$ that they were ever ready to take up arms to France. on behalf of the King of France to repel the German invaders, and that they were united to France by such strong ties of affection that they would sooner convert their country into a desert than let Germans take possession of it. “L'Alsace n'est pas à comparer à la Franche-Comté au point de vue de l'utilité que les Hauts Alliés en peuvent retirer. Car, outre qu'il est notoire que les habitants de l'Alsace sont plus français que les Parisiens et que le roi de France est si sûr de leur affection à son service et à sa gloire, qu'il leur ordonne de se fournir de pistolets, de hallebardes, d'épées, de poudre et de plomb toutes les fois que le bruit court que les Allemands ont dessein de passer le Rhin, et qu'ils courent en foule sur les bords du Rhin pour en empêcher ou du moins disputer le passage à la nation germanique, au péril évident de leurs propres vies, comme s'ils allaient au triomphe; en sorte que l'Empereur et l'Empire doivent être persuadés, qu'en reprenant l'Alsace seule, sans recouvrer la FrancheComté, ils ne trouveront qu'un amas de terre morte pour l'auguste Maison d'Autriche et qui couvera un brasier d'amour pour la France et de fervents désirs pour le retour de son règne en ce pays, auquel ils donneront toujours conseil, aide et faveur dans l'occasion." "

This union was definitively consecrated at the French Revolution, when a complete fusion between the French and the Alsatian people was effected. During

1 G. de Lamberty, Mémoires pour servir à l'histoire du XVIII' siecle, I4 vols. (Amsterdam, 1734-40), vol. v. p. 282 . 
the revolutionary wars Alsatian patriotism gave France distinguished leaders like Kellermann, the Voluntary victor of Valmy, and Kléber, the victor of fusion Maestricht, Altenkirchen, and the hero of the between Egyptian campaign; during the wars of the Alsatians. In Alsatians. Empire, Alsace produced more generals and men than any other French province-such names as Rapp, Lefebvre, Sirhanun, Berckheim, Hengel, and others are a permanent record of the attachment of Alsace to its adopted country. "From that time," said Fustel de Coulanges in 1870 , addressing himself to Germany, "Alsace has followed all our destinies; it has lived our life. All that we thought, it thought; all that we felt, it felt. It has shared our victories and our reverses, our glory and our mistakes, all our joys and all our sorrows. It has had nothing in common with you. In its eyes France is its fatherland, and Germany an alien country. . . . If your reasonings tell you that Alsace ought to have a German heart, my eyes and my ears assure me that it has a French heart." " He reminds the Germans, too, of the determined Alsatian resistance soon after the opening of the campaign and the reverses of the French armies; whether the valiant defenders spoke a Germanic tongue or not, they were the compatriots of the French and not of the Germans. Did the German soldiers who bombarded Strassburg, aimed at the cathedral, set fire to the New Temple, the library, hospitals and houses, feel that they were the countrymen of those they attacked so furiously and mercilessly ? "

Principle In conclusion, we may say, with the writer

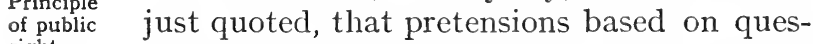
right.

tions of language, race, origin, matter little in comparison with the claim resting on the supreme 
principle of public right, whereby a population is entitled to be governed by the institutions that it accepts freely, and may not be detached from one State and attached to another without its voluntary consent. To claim a province on the ground that it once belonged to us is illegitimate; a province and its people are not an object of possession to be restored-for they belong to themselves. The province is not owned by the State to which it is united ; it is simply associated with it. The only reason why France wished to retain Alsace was that Alsace valiantly showed its desire to remain with France. France, as Fustel de Coulanges said aptly, did not fight in I870 to force it to remain with her; she fought to prevent Germany from forcing it to leave her. ${ }^{1}$ 


\section{CHAPTER VIII}

\section{GERMAN CLAIMS TO ALSACE-LORRAINE - ALLEGED GROUNDS OF ANNEXATION : (b) NECESSITY; CON- QUEST AS CONFIRMED BY THE TREATY OF FRANKFORT}

Claim on ground of necessity-Economic necessity: Outlet for overcrowded Germany ?-Natural deficiencies of Germany. Political necessity : German unity and the Reichsland. Military necessity: Frontier security-Mommsen on Metz. Conquest as confirmed by the Treaty of Frankfort: Prussia's territorial ambitions-Bismarck's admission in $1862-$ German views as to "right of conquest "-Recent growth of opinion as to conquest-Ground of illegitimacy of conquest-When conquest justified-International law as it existed in $187 \mathrm{I}$. Binding force of Treaty of Frankfort-Supersession of one treaty by another.

HAVING examined in the preceding chapter the German claims to Alsace-Lorraine on the grounds of earlier association, race and nationality, and use of Germanic dialects, and having shown their fundamentally irrelevant and untenable nature, we have now to look at the claims based on the further grounds of, first, necessity, and, secondly, conquest as confirmed by the Treaty of Frankfort.

The first of these grounds, necessity, may

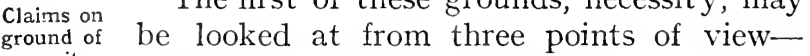
necessity. economic, political, military.

With regard to the question of economic necessity, several German writers had urged, before the annexaEconomic tion of Alsace-Lorraine, that the additional necessity. territory would serve as a kind of colonial outlet for the rapidly increasing population in Germany. But this contention is rather fatuous, considering the 
comparatively small area of the provinces-about 5,600 square miles, as compared with Germany's 209,000 square miles.

Moreover, events after the acquisition of the territory showed that crowded Germany gained very little indeed in this respect. The immigrant Germans constitute a small part of the total As an outpopulation, except in Strassburg (which is crowded about two-fifths German) and Metz (about Germany. three-fifths German); in such important industrial centres as Mülhausen and Colmar the native element easily preponderates. Even in Strassburg and Metz, as an American writer says, the germanisation in this respect is scarcely more marked than that of various manufacturing cities outside Germany, e.g. Milwaukee or St. Louis in the United States, or São Paulo in Brazil ; with the development of German industries, Strassburg and Metz, like other German manufacturing towns, received a substantial accession of unskilled " cheap labour," much of it temporary, from Poland and Italy. The lands of Alsace still belong to the Alsatians.' Furthermore, it has been calculated, that in the twenty-five years after the annexation the total number of Germans who settled in Alsace-Lorraine, including the considerable body of officials and their families, was far less than that of the emigrants from Germany in a single year. ${ }^{2}$

The provision for an outlet for the crowded districts of Germany being necessarily insignificant, other economic reasons were advanced to show the Natural denecessity of incorporating the territory-the ficiencies of fertility of its soil and the favourable configuration of its surface were deemed to be an indis-

1 Jordan, op. cit., pp. 63,64 .

- Ct. J. Heimweh, La Guerre et la frontiere du Rhin (Paris, I895), p. 84. 
pensable compensation for the natural deficiencies of Germany. This is an argument to which Treitschke had recourse in the pamphlet issued in I870 during the war." "Our sober judgment," he said, "cannot refuse to admit that nature has dealt with our country much more like a step-mother than a mother. The singularly barren outline of our shore coast-line on the North Sea, and the course of most of our German rivers and hill-chains are just as unfavourable to political unity as they are to commerce. . . . But here, in Alsace, there is a real German district, the soil of which, under favouring skies, is rich with blessings such as only a very few spots in the Upper Rhenish Palatinate and the mountain country of Baden enjoy. The unusual configuration of the country has made it possible to pierce canals through gaps in the mountains -magnificent waterways from the Rhine to the basin of the Rhône and of the Seine-such as German ground scarcely ever admits. We are by no means rich enough to be able to renounce so precious a possession."

An argument of this kind would be intelligible if it were a case of the contemplated acquisition of the provinces by fair, just, and pacific means, e.g. by purchase, exchange, etc. As it was, it was no more than the argument of a burglar who wants another's property. So that we need only say that neither the deficiencies of a country, in regard to its natural features or possessions, nor its inadequacy for accommodating its population, can possibly constitute a legitimate and valid reason, juridically or morally, for forcibly dismembering another country and seizing a part of it.

1 Was fordern wir von Frankreich? (Berlin, 1870). Eng. trans. in Germany. France, Russia, and Islam (London, 1915).

2 English trans., loc. cit., p. II 3 . 
Next, as to the political aspect of necessity. Many Germans claimed that the acquisition of AlsaceLorraine was essential for consolidating the Political German peoples and for effecting the unity necessity. of the Empire. "When our united strength," observes Treitschke, "has won that outwork of the German State, which is now in such mortal peril, the nation will have pledged its soul to the idea of unity. The resistance of the new province will strengthen the impulse of our policy towards unity, and constrain all sensible men to range themselves in disciplined loyalty behind the Prussian throne."

In reply to this contention we may say with Novicow, the Russian writer already referred to more than once, that the annexation of Alsace-Lorraine was not at all necessary for securing German unity, which, indeed, could have been established without the war of I870. And even Reichsland. if such a war as that of 1870 was really necessary for attaining this object, it does not follow that the dismemberment of France was also indispensable. The conduct of the war by the German States in common was one thing; the spoliation of France was a totally different thing. Already, after the victory of Wörth and the capitulation of Sedan, the peoples of Bavaria, Würtemberg, and Baden were united against the "common enemy"; and hence it was possible to conclude a reasonable peace on the conditions soon afterwards proposed by Jules Favre, including the principle of " no annexation." It has been suggested that Bismarck insisted on the abandonment of the French provinces not for the purpose of increasing German territory, but with the view of establishing along the western German frontier such a fear of

1 Loc. cit, p. III. 
renewed conflict as would necessitate and maintain the union of the German peoples. This view is superficially plausible, but far-fetched and inadmissible. The fear of a subsequent conflict with France could not have induced Bavaria, say, to enter a German Confederation, if she was really opposed to such a system. Had Bavaria been opposed to the establishment of such a system, and had she been resolved to preserve her separation and independence, she could easily have allied herself with France, as against the other German States that were bent on a union, in order to maintain and secure her political status. The South German States, indeed, had had no great love for Prussia; several times in the course of the nineteenth century they declared their preference for France. They agreed to form part of the German Empire, and remained in it, not because they feared a rupture with a reinvigorated France, but because such a policy was desired by them and was calculated to promote their interests. The theory that AlsaceLorraine furnished the necessary cement for binding the Empire, in view of possible French aggression, involves a confession of the then non-existence of German nationality. "Dire qu'il [the Empire] se tient uni seulement par terreur de la France, c'est nier l'existence d'une nationalité allemande." ' the contrary, Germans of all States have always loudly proclaimed their German nationality; whatever German pretensions may be disputed, this claim needs no proof. So that it is absurd to suppose, as Novicow well remarks, that it needed French bayonets to preserve the strength of this sentiment of common nationality.

Further, apart from considerations of political

1 Novicow, op. cit., p. 25. 
theory, dictates of public policy and national sentiment, actual events in the Franco-German War showed that the annexation of Alsace-Lorraine was not a sine qua non of German unity. We find, for example, that the arrangement between Prussia and Bavaria for the establishment of the Empire was concluded on November $25, \mathrm{I} 870$, and that the letter of the King of Bavaria to William I suggesting that the latter should assume the title and position of German Emperor was delivered on the following December 3. Thus the complete unity of Germany was already assured some three months before the Preliminaries of Versailles were signed, wherein the cession of Alsace-Lorraine was stipulated. King William was proclaimed Emperor at Versailles on January I8, I87 I-an act which was at once a solemn recognition of unity on the part of the constituent members of the Empire, and an open declaration thereof to the world. To dismember France after this political achievement was not necessary-however auspicious and appropriate a conquest might seem to a newly created Emperor and a newly founded Empire. "The Emperor and I would be guillotined," Bismarck is reported to have said, "if we returned to Berlin without Alsace and Lorraine."

Finally, assuming that the annexation of AlsaceLorraine was necessary for securing German unity, it does not by any means follow that the German States were entitled morally or legally to tear it away from France in order to promote their own interests.

The third aspect of the alleged necessity for the annexation relates to military security and self-defence. Thus Treitschke, speaking of the reparation Military that is to be exacted from "the disturber of necessity. the peace of nations," says: "What is demanded by 
justice is, at the same time, absolutely necessary for our security." 1 In his pamphlet of I870 the German historian, like other clamorous German claimants, called for the annexation of Alsace-Lorraine (as has already been pointed out) for reasons of race and nationality. Two years later, however, in a conversation with M. Monod on the alleged German origin of the Alsatians, Treitschke is reported to have observed: "All this is a swindle. Even if the Alsatians hal been Japanese, we would have annexed them just the same, because we had need of Metz and Strassburg from a strategic point of view." " Bismarck cared little for ethnological and linguistic arguments and for the kindred lucubrations of the German professorial class-room; without resorting to any subterfuge he openly avowed the main, if not the only, reason for requiring the cession of the provinces-viz. military strategy. Metz and Strassburg were sally-ports from France into Germany; therefore those, together with their surrounding territories, must be taken away from France. It has already been pointed out that he had, and for some time continued to have, doubts about Metz; but he yielded to the demands of the military staff, who emphasised that the possession of this town was alone worth two army corps. From the open doors of Strassburg and Metz the French were said to have invaded German territory twenty-three times; these doors must therefore be shut against them.

A German historian, whom we have quoted in the preceding chapter, has thus recently explained the true Frontier reason for the forcible acquisition of Alsacesecurity. Lorraine: "The motive for the annexations," he says, "is often misrepresented. Every-

1 op. cit., p. 100.

2 G. Monod, Allemands et Français (Paris, I872), p. I 51 . 
one knows the famous words spoken by Leopold von Ranke, the historian, to Thiers in the autumn of I870, after the fall of Napoleon III : 'It is against Louis XIV that we have now to wage war' ; that is to say, we have now to fight against the country which has for centuries looked upon the defenceless condition of the Germans as the strongest bulwark of her own hegemony on the Continent. Bismarck's motive for the annexation lay in no faded memories of past imperial history upon which national enthusiasts dwelt, but in the real and pressing necessity for permanent military defence of German unity against all attacks from the west-a unity which had been threatened, so lately as I866, by the preposterous demand of Napoleon III for the cession of Mainz and a portion of the left bank of the Rhine. This necessity alone impelled him to shift the frontier across the Rhine into the Vosges Mountains, for southern Germany had. been long enough at the mercy of French artillery. For this reason too, and for this alone, he decided, almost under compulsion from the generals, to acquire the fortress of Metz, situated in the Frenchspeaking area, in addition to Alsace, which, with the large German element in its population, might be expected to become gradually assimilated to the Empire. The annexation, far from being a deed done on the spur of the moment by the caprice of an individual, was the inevitable outcome for both nations of several centuries of their history. . . ." 1

Mommsen, writing in 1870 when the annexationist demands were put forward on various grounds, pointed out that, whilst the annexation of Metz, Mommsen unlike that of Alsace and German Lorraine, on Metz. could not be justified by reason of nationality, senti- 
ment, language, etc., it might none the less be justified on the ground of frontier security. He did not indeed state this conclusion explicitly; he merely said that many Germans insisted thereon; and he, for his part, preferred to leave the matter undiscussed and to rely upon the "able hands which hold the destinies of the two nations." 1

Finally, we now have the declaration of William I himself, made in a letter, October 26 , I870, to the Empress Eugénie. (This letter was made public by M. Pichon at the beginning of March, I9I8.) "After having made immense sacrifices for her defence," observed the German sovereign, "Germany wishes to be sure that the next war will find her better prepared to repel the aggression which we may be certain will be made as soon as France will have prepared her forces and formed allies. That alone is the deplorable consideration, and not a desire to enlarge our country, of which the territory is big enough, which obliges me to insist on the cession of territories which has no other object than to make more remote the point of departure of the French armies that in the future will come to attack us."

Having shown that neither economic nor political necessity could lawfully sanction the forcible annexation of Alsace-Lorraine, it remains to consider whether military necessity, in the sense explained above, could justify it-for it was this military necessity that constituted the bulwark of the German claims. The consideration of this question involves an examination of the broader question of conquest in general; for after I87 I Germany held that, whatever validity her different claims possessed, the annexed provinces became hers by right of conquest, recognised and con-

1 Letters, loc. cit., p. 3 r. 
firmed by the Treaty of Frankfort, which settled the question once for all in the eyes of international law.

The underlying impulse that led to the dismemberment of France was Prussia's lust for territorial aggrandisement. Seldom had the wars of Prussia been waged purely for the vindication territorial of national honour or for the reparation of ambitions. wrong; whatever the cause and whatever the ostensible purpose might be, the fundamental aim of her wars has frequently, if not invariably, been the acquisition of territory and the extension of dominion. In regard to political theory the modern German mind appears to have impregnated itself with Machiavellian conceptions: for Machiavelli and his disciples the predominant object of politics was the aggrandisement of the State, and for them war was merely a continuation of politics carried out by more violent and more drastic methods. This is the frankly avowed view of such German writers as Clausewitz, Lasson, Jähns, Von der Goltz, Treitschke, Bernhardi, and others. The glory, dignity, greatness, and prestige of a State are by them measured by the area of territory and the number of subjects governed. An idea of this kind was in the mind of the late Emperor Francis Joseph when he said on one occasion : "I want to end my reign with as many square kilometres as I began it." 1 What he lost in Lombardy and Venetia he made up in Bosnia and the Herzegovina. A victorious sovereign took possession of territory to show, too, that he had no fear of the vanquished; for to renounce conquests implied a respect for the rights of man-but mediæval and traditional records considered such respect as a " revo-

1 Cf. Le Matin, January 24, 1909; cited Novicow, op. cit., p. 28. 
lutionary " tendency that must be repressed." To this school of thought belonged the Prussian sovereign Frederick the Great, who once said: "Let us first take; we shall find jurists afterwards to legitimise our rights."

The territorial ambitions of Prussia were fully recognised by Talleyrand at the time of the Vienna Talleyrand Congress; he realised her disposition to on Prussian fasten on any pretext, to stop at no scruple, ambition. to measure law and right by her own interests in seeking to augment her dominions ; and he therefore emphasised the absolute necessity of preserving all the small States of Europe: "En Allemagne, la domination à combattre est celle de la Prusse: la constitution physique de sa monarchie lui fait de l'ambition une sorte de nécessité; tout prétexte lui est bon, nul scrupule ne l'arrête, la convenance est son droit; il est donc nécessaire de mettre un frein à son ambition en restreignant d'abord autant qu'il est possible son état de possession en Allemagne par la conservation de tous les petits états et par l'agrandissement des états moyens et en paralysant son influence par l'organisation fédérale."

Thinking of this Vienna settlement and of the Prussian annexationist policy, Bismarck observed in Bismarck's his noteworthy speech of September 30, I862: admission "Prussia must collect her strength for the in 1862. propitious moment which has more than once been allowed to slip by. The frontiers assigned to Prussia by the Congress of Vienna are not good for a healthy and strong State. It is not by speeches and the votes of majorities that the questions of our time will be settled; it is by iron and blood." These words were a fitting prelude to the subsequent war 
enterprises of Prussia and her wholesale annexations. Bismarck found a worthy colleague in Moltke, who did not hesitate to declare that conquest was in conformity with the order of things established by God.

This view was elaborately set forth in I87 I by Adolf Lasson. ${ }^{1}$ It is only in recent times, he says, that the "right of conquest" has begun to be doubted. The theory that conquest views as to is robbery and brigandage is based on the principle of the inviolable character of fron"right of conquest." tiers. These ideas have a significance only in so far as States are considered the property of these sovereigns. In free States the condition of things is different. Each State that goes to war with another State puts its own existence at stake, and must therefore submit to the losses entailed by defeat. The conqueror is empowered to act towards the vanquished as he deems fit, because the latter would have proceeded in a similar manner had he been the victor. A conquest is justified only when it is in the interests of the conquering State; then it is as reasonable as any other measure that is dictated by the "reason of State." \& It is really unnecessary to refute such arbitrary assertions and gratuitous assumptions, which are repugnant to civilised mankind and to the juridical consciousness of the family of nations; the reasoning based thereon is as fallacious as it is superficial. What difference is there between an autocratic sovereign making a conquest, and a republic making one? The evil inflicted is the same in both cases. Does the possession of liberty in a republic confer the right to violate the liberty of a neighbouring country? If a conqueror may do what he likes with the conquered, it means that

1 A. Lasson, Princip und Zukunft des Völkerrechts (Berlin, I87I).

2 Ibid., p. 82. 
the conquered becomes a thing of the conqueror: this is a negation of right, and not right. To speak therefore of a right of conquest is, strictly speaking, a contradiction: right as between States necessarily implies the existence of States, so that to put an end forcibly to the existence of a State is inevitably to step outside the sphere of right. ${ }^{1}$

To make up for the deficiencies of an abstract theory of conquest German writers point, in defence of the practice, to the various notable precedents Recent
growth of furnished by European history. The French growth of
to conquest. to conquest. conquest, but in the wars of the Empire it was resumed. The succeeding half century (I8I5I864), however, saw a markedly progressive movement. Many notable territorial modifications were, indeed, effected in this interval, for example, in the case of Greece, Belgium, the Danubian States, France, Italy; but these were all in conformity with the desire of the populations concerned, and were carried out in their interest. The more recent examples that Prussia could cite in I87 I were her own, viz. those of I864 and I866; but those created by Prussia's own proceedings could not legitimately be invoked by her as valid precedents.

The defenders of conquest and annexation ask, What law does international jurisprudence prescribe that Written and prohibits the practice? It is true there is unwritten no written law against it; but modern law. nations feel that there is none the less an unwritten law, inasmuch as such a prohibition is of necessity implied in the universally recognised principle that States and peoples possess the fundamental and inalienable right to dispose of their own destiny.

\footnotetext{
1 Cf. Novicow, op. cit., pp. 208, 209.
} 
This principle must have been recognised even in Germany after the events of 1848 and the parliament of Frankfort; and subsequent events further enlightened European public opinion on the question. A plebiscite came to be regarded as an indispensable condition for sanctioning an annexation. Thus was the unity of Italy established, and thus were Nice and Savoy added to France. That the plebiscite in the case of the latter was not (as some German writers have contended) a mere piece of jugglery on the part of Napoleon III is shown by the loyalty and attachment of these provinces to France in the hour of her supreme agony in I870; not only was there not the least sign of revolt, there was not even a protest against the annexation of I860. ${ }^{1}$

The recognition by the modern world of the intrinsic illegitimacy of conquest and forcible incorporation is based ultimately on the axiom that a man,

a group of men or a nation cannot be the Ground of possession of another man, group of men, or of conquest. nation-an axiom all the more applicable to and ineradicable from a society of Christian peoples. To deny this axiom is a negation of law and order, and amounts to an apotheosis of brute force and international anarchy. The advance of modern civilisation is irrevocably in the direction of liberty and equality; a world catastrophe like the present may reveal here and there retrograde tendencies, but it has shown that nearly all the nations of the world are prepared to face slaughter and devastation rather than abandon their loyalty and devotion to the sacred cause of justice and right, freedom, and equality, rather than give up the right to dispose of their own destinies.

Further, if in the case of an annexation of another

1 As to the question of plebiscite see further infra, chap. xvii.

IO 
State's territory and population, no assimilation or moral conquest has been brought about in a con-

Failure to assimilate as an additional condemnation. siderable period of time, the policy of the annexing Power stands condemned as much as its violation of the rights of the annexed population. To drag alien bodies within the circle of a State is a proceeding that is deprecated even by Treitschke. In a lecture on the nature of the State, he observed in reference to Napoleon's policy: "It was a sin against the spirit of history that the rich diversity of kindred peoples should be changed into the dreary uniformity of a world-empire. Such a naked policy of conquest in the long run destroys its own instruments ... it is a huge blunder. . . . It presumes to take possession of countries which cannot be fitted into the national State as living members." And yet at other times he spoke with contempt of little nations, and of the expediency of more powerful neighbours to absorb them. We have already referred to the doubts and apprehensions of Bismarck in regard to the annexation of Metz and the pays messin. Many German writers have been mentioned as supporting the alleged right of conquest; there were other German publicists and writers, however-e.g. Bebel, Liebknecht, Mommsenwho declared in I870 and I87I that conquest is illegitimate and indefensible. Thus Mommsen defended the German demand for Alsace-Lorraine on the ground that it involved a restoration and not a mere conquest. " If this were a matter of conquest," he said, " the case might reasonably alarm the nations, for every conquest is a crime against the rights of nations - to trample upon one nation is to offend all. . . . If these French provinces, with a German nationality, belong again politically to Germany, there will be no infringement of 
European political equilibrium." ' We may concede that the eminent historian sincerely believed the annexation of Alsace-Lorraine to be no more than a " restoration," by reason of its earlier association, nationality, and language. The weakness and inapplicability of these grounds have already been shown. As to his statement that the annexation would not infringe European equilibrium, subsequent facts proved that his historical vision and judgment of policy erred most grievously: for there is scarcely any other act in European history that infringed and endangered the equilibrium to such an alarming extent.

As a last resource, Germans claim that even if conquest is unjustifiable generally, it is justified when there has been serious provocation on the part of the defeated State. Thus they $\begin{gathered}\text { When } \\ \text { conquest }\end{gathered}$ hold that France was the aggressor in I870, that she would have annexed German territory had she then been victorious, and that Germany was entitled to take possession of French territory as the reward of her victory and as the price of the aggressor's defeat. It has already been pointed out that Bismarck calculated that the French had invaded German territory on twenty-three separate occasions. He therefore felt doubly justified in taking away those districts which contained the sally-ports of invasion. In many quarters other than German it was believed that Louis Napoleon was really the aggressor, and that his conduct gave the victor - to use the phrase of the Duke of Argyll-" a right to annex conformably to the ancient acknowledged right of nations in successful wars." : Gladstone appears also to have been con-

1 Letters, etc.

2 Lord Morley, The Life of W. E. Gladstone, 3 vols. (London, 1903), vol. ij, p. 347 . 
vinced of " the deep culpability of France," and whilst he did not altogether differ from the Duke of Argyll, he condemned the "violent laceration " on the ground that the people of Alsace-Lorraine were attached to their country, and on general political grounds-viz. that such European complications would result therefrom as would imperil the peace of the Continent. ${ }^{1}$ On the assumption that France was the aggressor, Treitschke does not hesitate to pronounce in favour of annexation -a pronouncement that is couched in extravagant language: "If a reckless robber-war like this is to cost that frivolous people nothing more than a war indemnity, the cynical jesters, who worship chance and fortune as the only governing powers among the nations, and laugh at the rights of States as a dream of kind-hearted ideologues, would be proved to be in the right. The sense of justice to Germany demands the lessening of France."

We have now examined all the grounds of the German claims to Alsace-Lorraine-early association, nationality and race, language, economic necessity, political necessity, military necessity, conquest consequent on alleged French aggression-and we have already shown that all these grounds save the last are untenable.

As to the last, we must have regard to what the international law as it existed in I87 I said on the Inter- subject. This can be summed up briefly national law in a quotation taken from a recent work of in $187 \mathrm{x}$. the present writer": "Perhaps the only cases where a right of conquest may be pleaded are

1 Lord Morley, The Life of W. E. Gladstone, 3 vols. (London, 1903), vol. ii, pp. $346-8$.

2 Germany, France, Russia, and Islam (1915), p. 100.

${ }^{3}$ C. Phillipson, Termination of War and Treaties of Peace, pp. $3 \mathrm{O}, 3 \mathrm{I}$. 
where the people of a country are given to savagery, cannibalism, inhuman practices, or where in a war of self-defence it is found absolutely indispensable in the interests of general and more enduring peace to take away from an aggressive State a portion of its territory. As Fiore observes ' : 'La conquête d'un territoire ne peut pas être par elle-même une condition suffisante pour exiger la cession du territoire conquis quand le droit du vainqueur n'existe pas. Le vainqueur pourra imposer cette cession, quand elle sera justifiée par des conditions évidentes de moralité, et par un interêt général d'assurer la paix." " If a conquest, made on such grounds, is supported by the assent of the political and legislative authority of the country from which the territory is taken, by means of a treaty of peace signed as a bilateral transaction, then it is valid in the eye of international law, however it be deprecated and condemned by international morality and international politics.

Now we cannot enter here into the question of the Ems telegram and into the allegations that are sometimes brought forward that Napoleon was thereby wrongfully entrapped by Bismarck. In 1870 it was the belief throughout Europe that France was the aggressor, and that

Conquest as recognised in a treaty. belief has generally prevailed since. Assuming, then, the belief to be founded on fact, we must conclude that the annexation of Alsace-Lorraine after its conquest, and its formal cession by the Treaty of Frankfort, was a valid act transferring the legal title of France thereto to Germany.

Such an eminent authority as Lord Stowell maintained even that a treaty of cession was not indispen-

1 P. Fiore, Nouveau droit international public, 2 nd ed. ; traduit de l'italien par C. Antoine. 3 vols. (Paris, 1880); § 1696. 
sable to validate a conquest. Thus when Heligoland fell into British possession by conquest, and before its formal cession by the Treaty of Kiel, I8I4, he held that the island in the circumstances became rightfully the property of the British Crown, and that a conqueror was entitled to alienate domains as soon as he acquired firm possession. "No point," he said, " is more clearly settled in the courts of common law than that a conquered country forms immediately part of the King's dominions." 1 This pronouncement must be taken subject to the qualifications implied in "firm possession": some time must elapse in order to allow the conqueror's claim to ripen, and to obtain or enforce definitively the acquiescence of the defeated country and the recognition of the conquest by third States. And such acquiescence and recognition are ensured by a treaty of cession, or a treaty of peace stipulating the cession of the territory concerned.

That conquest followed by such a treaty confers a good and lawful title has also been recognised by the American Courts. ${ }^{2}$

The same view is held by practically all international jurists. We must add here, however, that due account must be taken of the recent development of universal public opinion-the father of public lawwhich is strongly against the forcible annexation of territory on any grounds whatever.

1 The Foltina (1814), I Dodson, 450-5I; referring to Campbell v. Hall (I774), Cowper, 208.

2 U.S. $v$. Hayward (I8I5), 2 Gallison, 485; U.S. $v$. Rice (I8I9), 4 Wheaton, 246; American Insurance Co. $v$. Canter (I828), I Peters, 5 II.

${ }^{3}$ It is beyond the limits of our space to cite more than one or two leading modern representatives: J. C. Bluntschli, Das moderne Völkerrecht (Nördlingen, 1872); French translation by C. Lardy, Le Droit international codifié, (Paris, 1895$), \S 286$; C. Calvo, Le Droit international, théorique et pratique. 6 vols., $5^{\text {th }}$ ed. (Paris, I 896 ); vol. v. § 3 I 41 . 
Further, the Treaty of Frankfort must be regarded as possessing binding force from the moment ratifications were exchanged (May 20, I87I) till the moment it is superseded by another formal treaty. No such formal treaty has yet been concluded; therefore, notwithstanding the

Binding

force of

Treaty of

Frankfort. existence of the present war, the Treaty of Frankfort retains its legal validity. ${ }^{1}$ It does not belong to the class of treaties that are annulled ipso facto on the outbreak of war between their signatories, nor to the class of treaties suspended during the continuance of hostilities. A treaty of peace, involving a cession of territory, delimitation of boundaries, creation of servitudes, etc., is a dispositive or transitory treaty, which establishes a permanent condition of territorial rights, and cannot be affected by war between the parties thereto. From the point of view of international law and practice it is just as binding during war as treaties entered into expressly for the event of war, or general law-making treaties, like the Hague Conventions, the Declaration of Paris, I856, the Declaration of St. Petersburg, I868, or treaties effecting permanent international settlements, like neutralisation treaties, and so on. This is a well-established principle of international law: it is accepted and acted on by States, emphasised by jurists, and declared by courts of law. ${ }^{2}$

It appears to be thought in some quarters that a treaty imposing humiliating conditions, especially so on a great Power, is not a moral engagement which such Power is obliged to observe: whence it would follow that the Treaty of Frankfort, whereby France

1 As to the binding character of treaties of peace see Phillipson, op. cit., pp. I62 seq. Cf. the declaration of the Bishop of Strassburg, in/ra, pp. 186, I87.

2 As to the effect of war on different classes of treaties, see Phillipson, op. cit., pp. 250-68. 
was compelled to cede a portion of her territory-to her great humiliation-might be disregarded by her whenever she thought fit to denounce it.

Is a humiliating But nearly every treaty of peace imposes

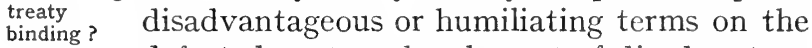
defeated party; the element of disadvantage or humiliation does not, from the point of view of international law, vitiate such a transaction, whatever resentment and righteous indignation it may produce, whatever desire for retaliation it may engender. Unsatisfactory peace treaties have no doubt led to war in many cases; and it may be that a party that had previously felt itself humiliated managed, in the subsequent conflict, to gain such a success as to enable it to reverse the prior decision and to conclude a more satisfactory treaty. Here, however, it was not the unsatisfactory character of the first treaty that deprived it of binding effect; it simply fell to the ground as soon as it was formally supplanted by the second treaty accepted and signed by both disputants as a solution of their difference. The first treaty remained legally operative until it was thus formally supplanted by the second.

Now international law does not demand that a nation, having been compelled through defeat to enter into an unfavourable transaction, should

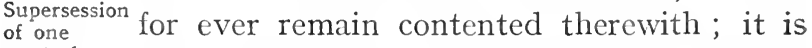
treaty by not the business of international law to
another. another. demand any such thing. It is entirely an affair of national policy and international politics. International law has not hitherto prescribed what grounds and causes are sufficient for undertaking a war-for resorting to this ultima ratio in order to redress a grievance. The Germans condemn the French revanchegelïst-hankering after "revanche," 
i.e. restitution, retaliation (not necessarily vengeance)as a reprehensible aim on the ground that it is contrary to the settlement effected by the Treaty of Frankfort; and yet they have themselves repeatedly declared that if they should one day be defeated and compelled to give up Alsace-Lorraine in a treaty reversing the dispositions of that of I87I, they would never rest content until they had once again wrested the territory from their conquerors. Recent pronouncements to this effect are familiar to all readers; we may supplement them by recalling such a declaration as was made before the present war by Dr. Arendt, a deputy of the Reichstag ": "If Germany be one day conquered and Alsace retaken, the German people will never cease to claim Strassburg and Metz, as a sacred and patriotic duty, and will be prepared to fight for centuries in a war to the death." Thus in the eyes of the Germans it is reprehensible and dishonourable for the French to seek to reverse the Treaty of Frankfort, but for themselves it is a "sacred and patriotic duty" to seek to reverse such treaty as may eventually supersede that of I87I. In point of fact, the Treaty of Frankfort itself superseded in regard to territorial arrangements a number of earlier treaties-e.g. the treaties of Westphalia (I648), Nimeguen (I678), Ryswick (I697), Utrecht (I7I3), and Vienna (I8I5)-and is in turn liable to be superseded by the regular and legitimate method sanctioned by international law, viz. the conclusion of a new international engagement.

We must conclude, then, that the Treaty of Frankfort is at present binding, and that Alsace-Lorraine still belongs lawfully to Germany and will continue to do so until she cedes it to France or otherwise renounces

1 Cf. Florent-Matter, L'Alsace de nos jours (Paris, 1908), p. 517 ; Novicow, op. cit., p. 203. 
her sovereignty over it. It is quite a different question, however, whether Germany has achieved a moral When conquest over the provinces, and has dealt Alsace- with the annexed people-formerly French Lorraine
will cease citizens - in such a wise, just, and equitable to belong manner as to absorb them into her political to Germany. régime and national culture, and make the severance from France complete. This is the question to which we have now to address ourselves. 


\section{CHAPTER IX}

\section{GERMAN RÉGIME IN ALSACE-LORRAINE}

Military occupation, I $870-7 \mathrm{I}-$ Status from February $\mathrm{I} S 7 \mathrm{I}$ to June $\mathrm{I} 87 \mathrm{I}$ Dictatorship, I871-3-The imperial constitution applied, $1874-$ Territorial Delegacy established, I874-Council of State established, 1879-Application of the régime-Repressive measures-New constitution, I9I I-Why autonomy refused-Precautions of Germany on outbreak of the present war--Why thorough germanisation not effected - The German official classes-The German immigrants-Pan-germanism-German methods compared with French.

From the middle of August I870, when the Germans entered into the military occupation of Alsace-Lorraine, to February 26, $187 x$, when the Preliminaries of Versailles were concluded stipulating its Military cession, the territory was placed under the $1870-7 \mathrm{x}$. authority of a military governor-general appointed by the King of Prussia, and was, conformably to international practice, subject to the martial and other law enforced by the former. During this interval it remained de jure French territory, though the sovereignty of France was suspended de facto and French law ceased to apply in so far as it was inconsistent with the provisional military law.

From the conclusion of the Preliminaries to the German law of annexation, June 9, I87 I (which came into force June 28, I87x), the régime of military occupation was no longer applicable ; $\begin{gathered}\text { Status from } \\ \text { February }\end{gathered}$ the rights of the acquiring State were derived $\begin{gathered}187 \mathrm{r} \text { to } \\ \mathrm{June} \times 7 .\end{gathered}$ from the formal cession; the status of the acquired territory with regard to third Powers was 
definitively fixed. It did not, however, become a constituent State of the German Empire under the German Constitution, which did not extend to it in proprio vigore.

The next was a transition period ${ }^{1}$ of two and a half years-June 28, I87I, to December 3I, I873Dictatorship, during which the German Emperor was not 187r-3. the ruler (in the sense of being ruler of Prussia), but the dictator of the Reichsland (imperial territory), exercising the functions of an imperial organ. On December 30, I87I, an official known as an Oberpräsident was appointed; he had an official seat at Strassburg, and acted under the direction of the Imperial Chancellor in matters of administration. $\mathrm{He}$ was not empowered to countersign ordinances of the Emperor, or to act as the representative of the Chancellor; but he prepared the budget and the drafts of laws and ordinances for the territory, which had to be submitted to the Reichstag for approval." Apart from legislative modifications made in this way, the existing French law remained operative for the time being.

We may mention here that soon after the formal annexation an assembly of Alsatian notables in StrassLaw of military service introduced.

burg appealed to the German Government to postpone the introduction of the law of military service into the transferred territory - for obvious reasons. But the appeal was rejected. Treitschke's observations in the Reichstag represented the view of the governing authorities, and amounted to a glorification of the German Army and

1 For a convenient summary of the status and changes from 187 I to 1879 , see B. E. Howard, Alsace-Lorraine in its relation to the German Empire, in Political Science Quarterly (New York, 1906), vol. xxi., pp. 447-74.

${ }^{2}$ Ct. P. Laband, Das Staatsrecht des deutschen Reiches. 3 vols. (Freiburg i. B., $1876-82$ ), vol. ii. p. 218 . 
German military discipline as the unfailing source of the noblest virtues. "This wish," he said, " proceeds from the scanty knowledge of German life which still prevails in Alsace ; it proceeds in the first place from the vague idea that there may some day be a war with France, and the hearts of the Alsatians revolt against the thought of fighting against their old fellow-countrymen. But we cannot come to an understanding with the Alsatians until they give up such vague expectations, and learn to regard their present condition as one which will last for ever. Further, that wish proceeds from a confusion of the French and German military establishments. Our army is not an aggressive power intended within a measured interval to return home with a certain amount of military glory; it is the nation in arms, it is the great school of courage, of manly discipline, of moral self-sacrifice on the part of the whole flower of the nation, and from this great school we do not wish to exclude the Alsatians at the outset. On the contrary, I say that the German law of military service should be introduced as soon as the economic conditions of the frontier territory admit of it." '

Under the law of June 25, I873, Alsace-Lorraine was empowered to return fifteen members to the Reichstag at the next election. On January I, The imI874, the imperial constitution came into perial conforce and the dictatorship of the Emperor applied, ipso facto ceased; so that the law-making 1874 . power was transferred to the ordinary legislature of the Empire. In the preceding year, however, it was enacted that when the Reichstag was not sitting the Emperor might, with the consent of the Bundesrat (the Federal Council), issue decrees having the force

1 Germany, France, Russia, and Islam, pp. I84-5. 
of law, provided they were not incompatible with the constitution or with the existing imperial law. Though the legislative powers had thus been reshuffled, the dictatorial régime none the less remained in fact.

At the meeting of the Reichstag on February I8, I874, the Alsace-Lorraine deputies presented a protest, in the form of a motion, against the annexation (we shall come back to this in the next chapter ${ }^{1}$ ); and-as a sequel to this protest-the Abbés Guester and Winterer moved in the Reichstag on the following March 3 that the dictatorial régime should be abolished. Bismarck, in. reply, reminded the Alsatian representatives that the annexation was that of a conqueror, that they themselves were also responsible to some extent for the war, and that the kind of government to be given to the conquered provinces depended only on the will of the victor. "These gentlemen of Alsace," he observed, " complain that, during these three years, we have not made them happy, as they no doubt were under French domination. . . . But that was not exactly the object of the annexation. . . . I will beg these gentlemen of Alsace, in order to abate their wrath, to remember also a little the way in which annexation was arrived at. . . Each of them has his own 30,000,000th share of complicity and responsibility in the war which was declared against us. . . ." Bismarck did not confine his mockery and sarcasm to the Alsatian deputies, but directed his pungent observations also against the French Government and the French Assembly. "If such speeches, in the event of French victory, had been uttered at the Assembly of Versailles, we may be certain that, if not the majority, at least M. le President Buffet, with the cutting manner that is peculiar to him, would 
soon have made liberty of speech an illusory privilege for the complainants." Bismarck concluded in favour of maintaining the dictatorial régime, and on a vote taken his view was supported by I96 against I38. The latter figure shows considerable progress in support of the amelioration of the status of AlsaceLorraine.

On October 29, an imperial decree authorised the establishment of the Landesausschuss, i.e. a Territorial Committee or Delegacy, consisting of thirty members (ten for each of the three districts of Upper Alsace, Lower Alsace, and Lorraine), whose function was to advise on established, I874. matters relating to local legislation and taxation, before bills were laid before the imperial legislature. The powers of this body were purely permissiveadvisory, and not consultative.

The results of the erection of the Territorial Delegacy being satisfactory, its functions were greatly extended by a law of May 2, I877, whereby Its functions it became also a consenting body in regard enlarged, to legislative projects, and could initiate territorial legislation. The legislature for the provinces now consisted of the Emperor, the Bundesrat, and the Landesausschuss (the approval of the Reichstag being no longer necessary).

Next, under the law of July 4, I 879 (which became operative on October I, I879), a great change was made, which marked a notable stage in the move- Progressive ment towards autonomy. The administra- $\begin{gathered}\text { Progressive } \\ \text { change in }\end{gathered}$ tion was dissociated from the Imperial Chan1879. cellor; the office of Oberpräsident was abolished; and a Statthalter (governor) was appointed instead, the first to hold the office being Baron von Manteuffel. The latter, who represented the Emperor and not the 
Imperial Chancellor, ${ }^{1}$ was assisted by a Secretary of State, and three Under-Secretaries - the heads of the different executive departments; they were all appointed by the Emperor, and together constituted a "ministry for Alsace-Lorraine," with their offices at Strassburg, and to them were transferred some of the functions of the Bundesrat. The Territorial Delegacy was enlarged to fifty-eight representatives, thirty-four of whom were elected by the general councils of the three districts from their own members, four were appointed by the municipal councils of Strassburg, Metz, Colmar, and Mülhausen, and twenty were elected by the delegates of the rural communes; and the powers of the Delegacy were extended.

A Council of State, possessing advisory powers, was established; it consisted of the Secretary of Council of State, the Under-Secretaries, the President State established. chief attorney of this court, and from eight to twelve members appointed by the Emperor for three years; and was presided over by the Governor, or, in his absence, by the Secretary of State. There were thus six legislative and administrative institutions for Alsace-Lorraine: within the territory-the Governor, the Ministry, the Council of State, and the Delegacy; outside the territory-the Emperor and the Bundesrat.

The normal mode of legislating for the territory involved a roundabout and complicated procedure: Roundabout the bill was drafted by the local ministry; was legislation. submitted to the local Council of State ; transmitted to the Prussian Ministry, who, having given what has been termed a "certificat d'innocuité," : submitted it to the Emperor ; sent back to the Governor

1 Laband, op. cit., vol. ii. p. 229.

2 Wetterlé, op. cit., p. II2. 
for his counter-signature ; laid before the Bundesrat; passed through three readings by the Delegacy; again presented to the Bundesrat (by Prussia, as the presiding State of the German Confederation) for definitive ratification; promulgated by the Emperor (if he did not veto the measure). Laws could also be made, however, without the intervention of the Territorial Delegacy, e.g. by decree of the Emperor with the consent of the Reichstag and the Bundesrat; or even by decree of the Emperor with the consent of the Bundesrat, having the force of a provisional law. Thus no legislation of any kind was entirely within local control. The co-operation of the Delegacy was not essential, but only permissive ; and even when it was permitted to co-operate, the local ministry could appeal to the Reichstag (which, in fact, not infrequently interposed in the legislation of Alsace-Lorraine).

Such was the constitution and scheme of government that prevailed in Alsace-Lorraine for some thirty years. But the fundamental restrictions and disabilities imposed thereby did not affect the people so much as the mode and details régime. of the application of the régime and the attitude of the governing authorities, especially so of the minor officials.

Baron von Manteuffel, the first Statthalter, however, made during the tenure of his office (1879-87) a conscientious and persistent attempt to Manteuffel's win over the population by mild methods and success. sympathetic treatment. ${ }^{1}$ He realised that the annexed territory had once been French, and that time, patience and tact were needed for transforming the nationality of its population and gaining their voluntary

${ }^{1}$ Cf. P. A. Helmer, Alsace under German Rule (London, 1915), pp. I5, 16. 
allegiance. He respected their feelings, and took into account the differences of their outlook, their ways, education, culture, and religion. He was ever ready to associate with them, and to listen to their grievances. And yet, despite the respect and esteem which his generous and affable disposition procured him, the fundamental object of his governorship was, in the eyes of his fellow-Germans, far from being attained. As M. Helmer says: “ The first Statthalter's successes were purely personal. His loyal and generous attitude was incomprehensible to his compatriots. Baron von Manteuffel's manner of approaching the Alsace-Lorraine problem, and the principles which inspired him in his efforts to win popularity, were contrary to the spirit of the German nation. Germany, which had tardily achieved unhoped-for power, knew nothing of chivalrous traditions, nor of respect for the personality, the rights and interests of others. The tact and delicacy of Manteuffel, the nobility of heart which made him defer to the sentiments of the vanquished, were foreign to the great majority of his people." 1 He was even accused by Germans of siding with the native population as against the immigrant officials; and his countrymen demanded that his mild and indulgent administration should be replaced by a strict and uncompromising régime. He died in 1887 , and was succeeded as governor by Prince von Hohenlohe Schillingsfurst, who was specifically instructed by Bismarck to adopt more rigorous methods towards the people of Alsace-Lorraine.

In the meantime various happenings in France pointed to the possibility of a new Franco-German war, the object of which would be to restore the lost provinces. The feelings aroused in France on the 1 Alsace under German Rule (London, 1915), p. 16. 
occasion of the visit of Alfonso XII of Spain (I883), and afterwards during the Boulangist movement (I886 and I887), and by such incidents as "Protestthe Schnaebele affair (I887), " met with a ing "memready response in the Reichsland. However to Reichstag this may be, at the elections of January, Lorraine. x887, Alsace-Lorraine once more returned to the Reichstag "protesting" members-following the examples of I874, I88I, and I884-in spite of the pressure exercised by the German authorities to bring about a different electoral result. Now, Manteuffel having gone, and the provinces proving recalcitrant in their attitude and repeatedly hostile in their elections, a period of repression commenced.

At the same time the Alsatian-Lorrainers began to realise that, what with the political vicissitudes in France, the absence of national unity, and Autonomist the pacific policy of the greater part of movement. French democracy, the dream of liberation was a hopeless one; accordingly they attached themselves to the movement for autonomy within the German Empire, and "Alsace for the Alsatians" became the guiding watchword."

For many years the repressive measures were applied systematically and persistently to every side of social life, public activity, and exterritorial relation- Repressive ships. When the new governor was pressed measures. to adopt severe methods, he made the following comment in his note-book: "It seems that at Berlin they want to drive the annexed population to desperation and to open revolt, in order to suppress the civil power and set up again the military dictatorship." s Numerous edicts were issued-Abwehrgesetze (laws of

\footnotetext{
1 As to these see infra, pp. $217,22 \mathrm{I}$.

3 IVetterlé, op. cit., p. 36.

2 See infra, chap. $\mathrm{x}$.
} 
protection), known locally as "lois d'exception"-for "Lois d'ex- the purpose of combating the influences ception." emanating from France. Newspapers were from time to time suppressed, e.g. the Union, OdilienNewspapers blatt, Colmarer Zeitung, Mülhauser Volksblatt, suppressed. Echo de Schiltigheim, Lorraine Sportive. Clubs and societies were arbitrarily dissolved, e.g. Societies the "sport" clubs of Metz, the souvenir dissolved. societies for the decoration of French graves, the Alsatian Society of Mechanical Construction (its head being a Frenchman), as well as various singing, music, and gymnastic societies. Restrictions were imposed on correspondence, the movements of excurCensorship. sionists, the performance of French plays. Censorship. Ardent "nationalists" (e.g. M. Antoine and M. Lalance) and also sympathetic visitors from France or Switzerland, were imprisoned, banished, or expelled.

The Alsatians and Lorrainers who had emigrated from their country in pursuance of the right of option Passport conceded to them by the Treaty of Frankfort system. were not allowed to return except with permits, which were obtainable with difficulty and available only for very short periods. For some fifteen years the passport régime was enforced, which to a large extent isolated Alsace-Lorraine from the rest of the world,' and--what was the greatest of hardships-separated the native families from their numerous French relations. Von Caprivi, the successor of Bismarck, stated on June Io, IS9o, that he had decided to maintain the passport regulations " in order to make still wider the barrier that separated France from Germany." French officers who crossed over into the Reichsland had to submit to rigorous 


$$
\text { RÉGIME, I870-I9I4 }
$$

and humiliating formalities, whilst German officers moved about freely at Nancy, Belfort, and Toul. The natives were regarded with suspicion, their words and acts were watched, espionage. and the practice of espionage and delation was resorted to: "La délation avait en effet été érigée chez nous à la hauteur d'un principe de gouvernement." '

The natives were excluded as much as possible from public functions; in case of disputes between them and the immigrants, judicial decisions sometimes unfairly favoured the latter " Pour frclusion times unfairly favoured the latter. "Pour from public l'habitant autochtone de l'Alsace-Lorraine, il n'y avait plus ni justice, ni droit, ni liberté. Avec toutes les formes hypocrites de la légalité, on en faisait un paria dans son propre pays." ‘

Most of the business orders of the administration were sent to Germany, and all kinds of devices and contrivances were adopted to get the indus- Economic trial undertakings of Alsace-Lorraine into pressure. German hands. " . . Malgré nos protestations indignées, toutes les commandes des administrations civiles et militaires allaient à des fournisseurs d'outreRhin; toutes les grandes entreprises industrielles, mines de fer, de charbon, de potasse, passaient aux mains de syndicats germaniques. L'affaire de Grafenstaden et l'enquête ouverte l'an dernier par les chambres de commerce sur la participation des capitaux étrangers aux affaires alsaciennes-lorraines, prouvèrent que les Allemands avaient même l'intention arrêtée de s'emparer des maisons existant avant la guerre de I870." s

Furthermore, the University of Strassburg was thoroughly germanised. The children of the Educational natives were discouraged to attend the inter- measures. mediate and the higher schools. French instruction

\footnotetext{
1 Wetterlé, op. cit., p. 32.

2 Ibid., p. 34 .

3 Ibid., p. 33.
} 
in the secondary schools was limited, and as far as possible had to be given through the medium of the German language.

In the case of the elementary schools French was banished altogether, except in certain entirely FrenchFight against speaking villages. The Government seemed French to be determined to eradicate the use of the language. French language in the annexed provinces. Business signs and notices had to be written or printed in German, special permission being required for the use of French. Such words as coiffeur, menu, restaurant, modes, etc., etc., were banned; they had to be replaced by friseur, speisekarte, restauration, moden, and so on. A Strassburg trader was fined for using the foreign expression, liquidation totale, instead of the German form totale liquidation; after paying the fine he put up a notice, " Hier wird Deutsch gesprochen." " "The struggle against the French language," says Paul Déroulède, " is one of the most ridiculous aspects of the pangermanist campaign. French souvenirs, French monuments, French tombs, French cookery, French bills of fare, French visiting-cards, French teaching, French Christian names, French gymnasium suif, French bugles, excite the wrath of the pangerm ists. They would even germanise red skirts ard blue skies. They would raise between Alsace and France, her former country, a Chinese wall." :

In reference to the German policy directed against the French language and French culture in AlsaceLorraine, a Swiss writer observes: "The old policy of the Allemanni in enslaving their conquered foes is revived in the nineteenth century. Not slavery in a

1 Jordan, op. cit., p. 52.

2 Preface to H. Zislin, Sourires d'Alsace (Paris, I 913 ). 
physical or economic sense, of course, but touching their purest, most intimate and most legitimate feelings. Slavery of the body may be more easily borne than constraint of the spirit." 1

It was to this period of repression that the Alsatian deputy, M. Preiss, referred when he said in the Reichstag on one occasion " that peace reigned in Alsace-Lorraine-the peace of cemeteries." "

In the meantime the movement in favour of autonomy was advancing; and it was felt in Germany that the governing officials, who constituted The official a kind of "close oligarchy," " had by their oligarchy. meddlesome disposition and arrogant behaviour contributed not a little to the alienation of the inhabitants and to the progress of the " nationalist" cause. Accordingly the Emperor intervened personally, and put an end to the ascendancy of the official circle. The Secretary of State, Von Puttkammer, was dismissed ; and Von Koeller was ap- Von pointed in his place, with instructions to régime. inaugurate a policy of conciliation and pacification. The latter did much to restrain the interference of the officials and to allay the general irritation. The dictatorial abuses were to a large extent remov and "exceptional laws" were repealed. The new ofvernment, interposing little in public life, and leaving it to the free play of the party organisations, thus countered the political opposition to the sovereign authority and reduced it to comparatively small dimensions. "If the national question," says a leading observer, " had been a mere outcome of the political situation, it might have been supposed that germanisation had now been achieved." " But, owing to the insolent and

1 A. Gobat, Le Cauchemar de Europe, cited by Jordan, op. cit., p. 53.

2 Wetterlé, op. cit., p. I43. ${ }^{3}$ Helmer, op. cit., p. $21 .{ }^{2}$ Ibid., p. 27. 
contemptuous attitude of the German immigrants and the consequent conflicts between them and the native population, Alsatian disaffection was nourished and demands for autonomy were renewed.

Next Von Koeller was replaced by Baron de Bulach, an Alsatian statesman, "qui crut devoir inaugurer Baron de immédiatement, pour se faire pardonner ses Bulach's origines, la politique de la 'main forte.'" $\mathrm{He}$ régime.

became the tool of Herr Mandel, a Bavarian, the Under-Secretary of State for Foreign Affairs, a harsh man devoted to the strict and undiscriminating application of the written law- " un Bavarois dur et grossier, le type du légiste qui ne connaît que la loi écrite et l'applique sans ménagements." ' The policy adopted was a resumption of the high-handed régime, which had met with failure throughout; and before long there was an open rupture between the ministry and the Territorial Delegacy. Various incidents contributed to this : e.g. the prohibition of the performance of Racine's comedy, Les Plaideurs, the stormy debates on the Kubler motion relative to the teaching of French in the elementary schools, the affair of Noisseville and the Weissenburg monument (1908), 2 the expulsion of the Swiss Wegelin for causing the Marseillaise to be played in a Mülhausen restaurant, the trials of the native artists and caricaturists Hansi and Zislin, the closing of the students' club, the incident of the play in The Daughter of the Regiment at the Colmar theatre, and finally the indignation aroused in the Territorial Delegacy by the observation of the Secretary of State: "The Empire owes you nothing." Proceedings such as these could not but give rise at the meetings of the Landesausschuss to bitter and excited discussions, "que l'incapacité du Secrétaire

1 Wetterlé, op. cit., p. I 6.

2 See infra, p. 198. 
d'Etat et l'impertinence de M. Mandel transformaient en scènes scandaleuses "- -as an eye-witness says."

In these circumstances the Secretary of State urged upon the Governor, Count von Wedel, that, in view of the difficulties of the political position in Efforts Alsace-Lorraine, it was essential to modify $\begin{gathered}\text { against the } \\ \text { nationalist }\end{gathered}$ its constitution in such a way as to get rid of movement. the nationalist opposition. The nationalist programme contained four fundamental demands: (I) that AlsaceLorraine should be made a State of the German Empire ; (2) that the executive authority should be vested in an independent head, either prince or president ; (3) that a legislative body should be established within the State, with powers similar to those possessed by the legislative bodies of the other German States; and (4) that the interposition of the Emperor, the Reichstag, and the Bundesrat in legislation exclusively relating to Alsace-Lorraine should be abolished.

The Imperial Chancellor, Herr von Bethmann-Hollweg, expressed himself in favour of reform. At the end of I9Io a Government Bill," approved by Government the Bundesrat, was laid before the Reichstag. Bill, rgio. Its main proposals were: (I) that Alsace-Lorraine should remain an imperial territory (Reichsland); (2) that the Emperor should continue to exercise sovereign authority, as the agent of the confederated States, through his representative, the Statthalter, at Strassburg; (3) that the legislative powers of the Bundesrat and Reichstag in matters relating exclusively to the territory should be abrogated; and (4) that two chambers-an upper and a lower-should be established, the second of which was to be elected by manhood suffrage.

In the Reichstag debates on the Bill there was a 1 Wetterlé, p. II 7 . 
conflict between the autonomists and the conserva ives, who also objected to the provision for manhood suffrage. The measure was referred to a special committee, who suggested amendments to the effect that the territory should be constituted a State of the Empire and that the Statthalter should hold office for life. The latter point was rejected by the Government; and in regard to the former a compromise was accepted whereby Alsace-Lorraine, though not raised to the precise status of a State, should be allowed three votes in the Bundesrat, which were not to count either in favour of any Prussian proposal except when Prussia gained a majority without them, or (whether for or against) in the case of any proposal to amend the imperial constitution. The amended Bill was passed, May 3I, I9II, and the new constitution came into force on the following September I.

Various progressive features were thus introduced; the rights of the population were very considerably enlarged. As before, the Kaiser was vested New consti- with the supreme executive authority. The
tution enacted, Statthalter, appointed and dismissable by igir. the Emperor, exercised as his representative the executive power, together with all the rights that were formerly in the hands of the Imperial Chancellor. $\mathrm{He}$ was also empowered to appoint and instruct the three delegates at the Bundesrat. Imperial decrees and orders could not have the force of law without his signature. No bill could become law without the assent of the Emperor and the two Chambers. He was empowered to summon, adjourn, and dissolve them. The Upper Chamber was to consist of twenty-three members: five permanent ex-officio, viz. the Bishops of Strassburg and Metz, the Presidents of the two Protestant Consistories, and the President of the Court 
of Appeal ; the rest being elected members representing the University, the Jewish Consistory, the municipal councils, and the commercial, agricultural, and industrial associations. But the Emperor could, at the instance of the Bundesrat, appoint twenty-three others for the duration of the parliament-a serious defect that prepared the way for subservience to the imperial authority. The Lower House was to consist of sixty members elected by direct and secret ballot by male German citizens of twenty-five years of age who had resided for at least three years in Alsace-Lorraine (one year in the case of teachers and officials). The annual budget was to be submitted first to the Lower House, and was to be accepted or rejected in its entirety by the Upper House. If the former refused to vote supplies, the Government was empowered (as before) to raise taxes and issue treasury bonds.

The constitution could be modified only by the Reichstag and the Bundesrat, so that it rested on a precarious foundation. The Strassburg Government depended virtually on Berlin: for the Emperor appointed the Statthalter, and could dismiss him at discretion, and the

Position of AlsaceLorraine under it.

latter instructed the Bundesrat Delegates; and the composition of the Upper Chamber was to a great extent subject to the Emperor's pleasure- " la composition du Sénat plaçait nos institutions parlementaires au-dessous de celles des pays les plus rétrogrades." 1 M. Wetterlé thus sums up the position of Alsace-Lorraine under the Constitution of I9II, considering it most unfavourable, despite the reforms, real and apparent, introduced: "Nous restions, en théorie comme en fait, terre d'empire, propriété collective des États, colonie, jouissant, mais provisoirement seule-

1 Wetterlé, op. cit., p. 122. 
ment, du droit de s'administrer elle-même sous la souveraineté du roi de Prusse. Nous étions livrés pieds et poings liés au bon vouloir des pouvoirs législatifs et de l'exécutif de Berlin." " Similarly M. Novicow regards the constitution as a deception - "trompe-l'oeil" - as a "manifestation of political hypocrisy scandalously practised recently on so large a scale" : though it provided a senate, a chamber of deputies, universal suffrage, representation on the Bundesrat, etc., it did not give the essential thing, viz. the right of the people to manage their affairs as they deemed fit. ${ }^{2}$

Why the Imperial Government has refused Alsace- . Lorraine autonomy is a question that can be readily Why answered. It is because of the persistence autonomy of French feelings in the provinces, especially refused. among certain of the political leaders, and the imperfect germanisation of the territory and people as a whole. "L'unique raison," remarks M. Sembat," "qui a suspendu jusqu'ici l'octroi de cette autonomie, c'est la persistance des sentiments français dans les provinces annexées. L'administration allemande en prend, à la fois, alarme sérieuse, et texte commode aux exagérations patriotiques et au maintien des mesures arbitraires." In February I9 Io it is reported that the Secretary of State said to the deputies of the Territorial Delegacy at Strassburg: "Have the courage to declare that, being Alsatians, you are Germans, and you will receive autonomy at once." The constitution of I9I shows that the deputies were not prepared to make such a declaration. ${ }^{4}$

Herr von Bethmann-Hollweg, in the course of a

1 Wetterlé, op. cit., pp. 122-3.

2 Novicow, op. cit., p. 160.

3 M. Sembat, Faites un roi, sinon faites la paix (Paris, I9 I 5), p. I 70.

- Novicow, op. cit., p. 173. 
speech in the Reichstag March I4, I9Io, recognised the necessity of conferring on Alsace-Lorraine a larger measure of political independence; but he emphasised that the formula of the nationalists- "Alsace for the Alsatians" - could not be put into practice so long as their leaders affected to ignore the German character of the population, and were disposed to gallicise the provinces contrary to the considerations of history and ethnography. Again, in the Prussian Upper Chamber Herr Wedelpissdorf said on April 5, I9II: "The debates that have taken place in regard to a constitution for Alsace-Lorraine have aroused in us a deep anxiety, for we are of the opinion that the inhabitants of this country have not yet become German enough in order that it may be, without danger, constituted a confederate State." '

This opposition of the German Government on the one side and the alienation of sections of the people on the other constitute a dilemma which may be expressed thus. Germany says to Alsace-Lorraine: "I will not give you freedom until I am sure of your love." To which Alsace-Lorraine replies: "I cannot love you till you set me free." " Germany evidently does not think it safe to bestow on the Reichsland the complete liberty and rights of an autonomous State until the whole of the people are thoroughly imbued with the spirit of " Deutschtum," have fully absorbed German traditions and culture, and have become responsive to official discipline and amenable to the ubiquitous exigencies of a paternal Government. So far-till the outbreak of the present war-Alsace-Lorrainers have not, in the eyes of the governing classes, merited a higher category than that of second-class Germans-

1 Independance Belge, April 7, 1911; cited by Novicow, p. 173.

2 Jordan, op. cit., p. 3. 
"Deutsche zweiter Klasse"-to use an expression sometimes heard in Alsace.

With regard to the requirement of the German Government that the Alsace-Lorrainers should become fit for liberty before it is conferred upon them, we may recall the wiser and more generous view of Gladstone. The great Liberal statesman, writing to Mr. Forster (April I2, I882), on the occasion of the Irish land disturbances, observed: "It is liberty alone which fits men for liberty. This proposition, like every other in politics, has its bounds; but it is far safer than the counter doctrine-wait till they are fit." 1

A few months before the outbreak of the war it was thought in Berlin that a severer régime than that of Count von Wedel was necessary; accordingly

Régime under Dallwitz
von Roedern. Roedern, who - in the words of M. Wetterlé the latter was replaced by Dallwitz von " was to substitute rods of iron for rods of wood, and to resume in Alsace-Lorraine the reign of terror, so that the difficulties resulting therefrom might provoke the annexation of the imperial territory to Prussia." " It was, indeed, frequently advocated in German conservative and military circles that the Kaiser should be made Landesherr (sovereign) of Alsace-Lorraine and that it should be annexed to Prussia. Threats have more than once been made officially that this plan might be resorted to on account of the continued indocility of sections of the population and the agitation of parliamentarians and other national leaders.

Thus in May I9I2, after the Mayor of Strassburg had made a complaint in regard to some industrial

1 Lord Morley, Life of Gladstone (1903), vol. iii. p. $5^{8}$.

2 Wetterlé, op. cit., p. 127. 
injustice to the city, the Emperor is reported to have replied: "Listen; so far you have known only my good side. If this situation lasts we shall The Kaiser's suppress your constitution and annex you to threat, I9I2. Prussia." 1 In the following year, after the Zabern affair," Herr von Jagow remarked that in AlsaceLorraine his countrymen appeared to be in an enemy country.

Finally, a word remains to be said on the precautions and proceedings of the Imperial Government on the outbreak of the present war. ${ }^{3}$ It is stated that lists had been prepared containing the Precautions names of Alsatians and Lorrainers whom it Government was thought necessary to remove and keep of the preunder surveillance. One list contained the names of some three hundred persons who were to be arrested for preventive purposes on the eve of the mobilisation and handed over to the military authorities. Many of them fled. A second list contained a number of suspects who were regarded as less dangernus but whom it was thought advisable to remove from the Reichsland; they were accordingly taken away to various German towns and placed under police supervision. As for the territory generally, a rigorous régime was introduced. Foreign news was admitted only through the medium of German papers. Nearly all the local newspapers were suppressed or ceased to appear. A strict censorship was imposed on private correspondence. To leave Alsace was almost impossible; those who obtained special authorisation were subjected, before proceeding to a foreign country, to a sort of quarantine- " une sorte de quarantaine préalable"-in a German town. Restrictions were

\footnotetext{
1 Jordan, op. cit., pp. 58,59 , note.

3 Lichtenberger, op. cit., pp. 74,75 .
}

2 See intra, p. I98. 
imposed on the movements of the population. The use of the French language was entirely forbidden, even in private conversation. The least mark of sympathy shown towards the French-even kindness to the French wounded-was punished. The property of fugitives was confiscated, and their relatives were treated as suspects. On the declaration of war thousands - it is stated-fled, and enlisted under the French flag, some in Algeria, Morocco, or with the forces sent to Turkey, others in France.

We may conclude this chapter with a few words, supplementary to the various indications already why given above, to explain why the German thorough Government has not succeeded in Alsacegermanisa-
tion not effected. thoroughly the population-to bring about their entwelschung ("deforeignisation"). The Germans have not infrequently attributed their failure to their hesitation, and, above all, to their leniency in administration; they have thought it a mistake to permit of the least compromise in Lorraine with French sympathy, and in Alsace with Swiss republican ideals. Some of the Statthalters, e.g. Manteuffel, Zeppelin, Von Koeller, have therefore been censured for paying heed to local opinion.' Others, however, have taken an entirely contrary view, and have thought that the failure was really due to the excessive severity imported into the administration, advocated as it was by the militarists and the pangermanists; and they have held that the Imperial Government and the local ministries have erroneously considered Alsace-Lorraine responsible for or identified with the occasional chauvinistic or revanchard manifestations in France. 
The reason given by the latter critics is undoubtedly the right one.

The fundamental deficiency of the rulers was a lack of tact and sympathy, the indispensable attributes in a conqueror who would win loyalty from the conquered. The absence of these qualities means the use of an undiscriminating coercion, which in its turn alienates the

Fundamental deficiency of the rulers. sympathy and good-will of the governed; it is the reciprocally spontaneous good-will alone that is the true cement of nationality and the controlling force of allegiance. The Germans have, admittedly, produced great works of philosophy and psychology; but in practice they have failed to grasp the very essentials of national psychology. They appeared to believe, if we may judge of their proceedings in the Reichsland, that constraint is the father of adherence and affection ; whereas - to use the words of Novicow ${ }^{1}$ - to force people to love is as impossible psychologically, as it is impossible geometrically to force a triangle not to have three angles. The ignorance of the very essentials of social science on the part of Bismarck and Moltke and their successors led them to commit the radical mistake of substituting for the earlier false principle "cujus regio ejus religio," the equally false principle "cujus regio ejus natio." " Force provokes antipathy, hatred; it can never produce national organic amalgamation. To show the conquered that he is weak and cannot liberate himself, whilst the conqueror is powerful and if need be can crush him, is a policy that can never result in a natural fusion-it is at most an "assimilation caporaliste." " This is recognised by such a writer as Herr Naumann, who observes in his recently published well-known work: "Prussia took
1 L'Alsace-Lorraine, p. I53.
2 Ibid., p. 159 .
3 Ibid., p. 156 
compulsion in one hand and material prosperity in the other, and demanded loyalty in exchange. She brought about much good, but found no way to the heart of the people."

The introduction of a large number of German minor officials aggravated the difficulties of the situaThe German tion. Bismarck had himself fully realised official the necessity of importing into the territory classes. as few as possible; but what he saw clearly in $I 87 \mathrm{I}$ immediately after the formal annexation, was forgotten later on. The most unsympathetic, arrogant, and interfering of all the official caste were the Prussians ; they were devoid of tact and understanding, and withheld as much as possible from social relations with the people. Many of the lesser posts were filled by non-commissioned officers who were accustomed to the harsh and rigorous discipline of Prussian barracks. Karl Blind, an observer and publicist of wide experience, whilst favouring the cause of the Germans, emphasises this mistake: "Had the Berlin Government sent into the newly acquired provinces officials of a less hard type than many of those who came from Prussia, had more South Germans been appointed who better understood the kindred Alsatian character, the reconciliation would have made still quicker progress." "

The non-official German immigrants were naturally of the same metal as their official brethren, although The German they were not in a position to inflict adminisimmigrants. trative hardships. The hostility, open or concealed, between them and the native population was due to the same fundamental causes as have been

1 F. Naumann, Central Europe, English trans. (London, I916), p. 79.

2 Alsace-Lorraine and William $I I$. (with personal recollections), in Fortnightly Review, vol. Ixxviii. (1902), pp. 257 seq., at p. $25^{8}$. 
mentioned above. The immigrants generally assumed an attitude of superiority; they thought they came as enlightened missionaries, devotees of the vaunted Kultur, to bring the light to a benighted country and true civilisation to a backward and inferior race. There were naturally marked differences between the newcomers and the old inhabitants: the former were believers in force and in ready obedience to bureaucratic regulations, they were hustlers, and were not endowed with a sense of humour; the latter were profoundly democratic, easy-going, they appreciated the ridiculous side of things, and were not infrequently moved to laughter at the bombastic pretentiousness of their new neighbours. The Germans invariably preserve wherever they go their distinctive national characteristics-their manners, customs, prejudicesand they seem as incapable of being assimilated as of assimilating. "The self-conscious isolation of the German," says Sir Thomas Holdich, " his unbending belief in his own high destiny, added to a certain want of the magnetic attraction due to perfect tact and manners, militates against his success as a colonist, as rnuch as his tactless appreciation of the worst form of Prussian militarism foredoomed the failure of peaceful administration in Alsace and Lorraine, and reidered the annexation of these two provinces a great blunder." 1

No wonder, then, that for a long time the immigrants were not received in the native families, and that marriages between Germans and Alsatians or Lorrainers were very rare; so that, despite the comparatively large immigrant population of 300,000 as against the native population of $\mathrm{r}, 800,000$, there has not been any

1 Sir Thomas H. Holdich, Political Frontiers and Boundary-making (London, I916), Pp. 24, 25 . 
fusion, or even real contact, between the Schwob ${ }^{1}$ and the Welsche (or Französling). ${ }^{2}$

The greatest deficiency of all in the governing classes in Alsace-Lorraine is their incapacity to appreciate the Panger- spirit of the people, to understand their manism. regrets, their hopes, their tradition, and their aspirations. This incapacity is intensified by the pangermanists' reactionary, autocratic, and militarist conceptions, according to which a conquered population, if not conforming promptly and voluntarily to the standard set before them, should be subjected to the drastic methods of a Procrustean régime. Thus the writer of an article that appeared in the Elsässer Courier, a German paper of Colmar, makes the following pronouncement: "Were I Emperor, there would be a dictator, not a Statthalter, in authority. No student should enter the University of Strassburg till he had spent two years at a University elsewhere in Germany. All private schools should be closed, and all public schools should be taught in German. There should be no public meetings in which French is spoken, and no private gatherings save in the presence of a German official. No newspapers should be printed in French, and each paragraph in French should have by its side a German translation. Each citizen, as he comes of age, should declare his eternal allegiance to Germany. He should give his pledge not to buy secretly any newspapers, books, or periodicals in French. All this under pain of expulsion from the land.' '

It is this pangermanism that has throughout been in Alsace-Lorraine the obstacle to assimilation, peace,

2 An Alsatian name for a German.

${ }^{2}$ A German name for the anti-German native.

3 D. Frymann, Wäre ich Kaiser, an article published in the Elsä $a_{s s e r}$ Courier (Colmar), as copied from the Strasburger Post, July 1913; quoted by Jordan, pp. $32-3$. 
and good understanding, as it has been in Europe generally the obstacle to international amity and security. An Alsatian writer emphasises this in no uncertain accents. "Pangermanism is the exotic," he says, "which ruins the colour of Alsace. . . . It is evident that the only obstacle to the definite germanisation of Alsace is the pangermanist alone, the odious pangermanist under all his disguises, the pangermanist journalist, the pangermanist functionary, the pangermanist magnate, the pangermanist pedagogue, the pangermanist ecclesiastic, the pangermanist policeman, the pangermanist higher officer, the pangermanist subaltern, the pangermanist industrialist, the pangermanist trader. There is also the feminine pangermanist, and we have to call on all the vestiges of gallantry remaining to us from French times to induce us not to speak of her. That is all to her profit. When the last pangermanist shall be put under the sod, on that very day Alsace will find herself germanised as if by enchantment and with the best grace in the world. On that same day we shall have seen, sure as the dawn arises, the United States of Europe, to which the pangermanists constitute the sole obstacle, the day when international fraternity between States will efface them or leave them to retain only a conventional and administrative significance." 1

A point of great importance to note is that these pangermanist aims and tendencies are resisted in AlsaceLorraine even by the German Alsatians and Lorrainers, the immigrants' sons who were born in the territory; many of them are devoted adherents of the nationalist movement." This strong opposition to the Prussian

$1 \mathrm{~J}$. Froelich, Le pangermaniste en Alsace; quoted by Jordan, op. cit., pp. IOS-IO.

${ }^{2}$ See the next chapter. 
régime has been persistently offered in Upper Alsace, and in its two principal towns, Colmar and Mülhausen ; and also in Eastern Lorraine, which is Germanic by blood and speech. Indeed, the American writer to whom we have frequently referred goes so far as to say, as a result of his personal inquiries made in the Reichsland in the year before the war, that the political unrest there appeared to be more freely expressed by the inhabitants of Germanic origin than by those of French blood. ${ }^{1}$

In 1874 a distinguished Prussian publicist and writer issued a work * in which he examined the German policy inaugurated in the conquered

German methods country, and compared it with the methods compared adopted by the French. In view of the systematic exclusion of the French language, he asks what part can the French-speaking Alsatians play in the public life of Alsace. A language cannot be imposed on a people, he emphasises, without taking into consideration their antecedents, sympathies, needs, relationships, and the education of generations; the obstinate war made by the German Government on the French language will be condemned by history as a crime against the most sacred rights of humanity. ${ }^{3}$ He points out-with accuracy and notable impartiality - that the French Government, from the annexation of Alsace to France till the Revolution, pursued a different policy: it respected the institutions, the manners, and customs of the people; it left them nearly all their own laws and traditional usages ; and it never attempted to substitute by force French for German. That was why France since I789 obtained

1 Jordan, op. cit., p. 41.

2 G. Rasch, Die Preussen in Elsass und Lothringen (Braunschweig, 1874): French translation (Paris, 1876 ).

3 Ibid., chap. xii. p. 163 (Fr. ed.). 
the cordial attachment of the annexed population, and their devotion to French nationality. (It may be added that, for saying these things, the author was sentenced to four months' imprisonment, and the book was confiscated and suppressed.)

More recently the German ministerial Director, Herr Althoff, whilst asserting (after the notorious fashion of Herr Houston Chamberlain) the Political supremacy of his countrymen in every other incapacity. sphere, admits their political incapacity-the one failing. "We Germans," he is reported to have said to Prince von Bülow, " are the most learned nation in the world, and the best soldiers. We have achieved great things in all the sciences and arts; the greatest philosophers, the greatest poets and musicians, are Germans; of late we have occupied the foremost place in the natural sciences and in almost all technical spheres, and in addition to that we have accomplished an enormous industrial development. How can you wonder that we are political asses? There must be a weak point somewhere." This passage has been cited by Prince von Bülow, ${ }^{1}$ the German ex-Chancellor, as an argument against the institution of manhood suffrage in Prussia; the German people, he declared, are incapable of self-government. How can people govern others, we may well add, if they cannot govern themselves?

1 Prince von Bülow, Imperial Germany, English translation (London, 1916), p. I6I. 


\section{CHAPTER $\mathrm{X}$}

\section{VIEWS AND ASPIRATIONS OF ALSACE-LORRAINE-THE NATIONALIST MOVEMENT}

Protest of the Alsace-Lorraine deputies in the Reichstag, I874-Why autonomist movement began-Aim in social and intellectual life of the people-Method of the nationalist leaders-Differentiation between autonomists and protesters-Socialist party; anti-clerical campaignDemocrats leave the Catholic party-National Union formed, I9Io; its programme--Manifesto against the Constitution of I9II- " Home rule" demanded, 1913-Before present war, memory of 187 I fading in Alsace-Lorraine-Did Alsace-Lorraine desire reunion with France? -Noisseville affair; Saverne affair-Attitude of the people towards France and Germany-Distinctive personality of Alsace-LorraineThe new generation and France-Doubtful indications as to feelings and desires of the people-Attitude of Alsace-Lorrainers at outbreak of the war-Declarations of the two Chambers, I9I 7 -Conclusions.

THE first fifteen years of the history of Alsace-Lorraine under German domination may be described as " the period of protest," and the subsequent period may be designated "the era of young Alsace," when the autonomist movement was set on foot and developed, the watchword being "Alsace for the Alsatians." First, then, as to the period of protest.

On February I8, I874, at a meeting of the Reichstag, a protest against the annexation was submitted, in the form of a motion, by fourteen out of Protest of
the Alsace- the fifteen deputies of Alsace-Lorraine. The Lorraine
deputies in spokesman was M. Teutsch, an Alsatian the Reichs- advocate. ${ }^{1}$ He desired to express himself in ag, 1874. French, but was compelled to use German. The declaration he read was subjected to repeated

1 His speech is reprinted in French in Patiens, L'Alsace-Lorraine devant l'Europe (Paris, 1894), Appendix, Note B. 
interruptions, shouts, and sarcastic outbursts of laughter; and he was more than once called to order. The principal passages are as follows ${ }^{1}$ :

"The people of Alsace-Lorraine, whose representatives we are at the Reichstag, have entrusted to us a special and most grave mission, which we are anxious to fulfil without delay.

"Your last war, which terminated to the advantage of your nation, undoubtedly gave it the right to reparation. But Germany exceeded her right as a civilised nation in compelling France to sacrifice a million and a half of her children.

" In the name of the Alsatian-Lorrainers, sold by the Treaty of Frankfort, we protest against the abuse of force of which our country was the victim.

1 “ Les populations d'Alsace-Lorraine, dont nous sommes les représentants au Reichstag, nous ont confié une mission spéciale et des plus graves, que nous avons à cœur de remplir sans retard.

“ Votre dernière guerre, terminée à l'avantage de votre nation, donnait incontestablement droit à celle-ci à une réparation. Mais l'Allemagne a excédé son droit de nation civilisée en contraignant la France vaincue au sacrifice d'un million et demi de ses enfants.

"Au nom des Alsaciens-Lorrains, vendus par le traité de Francfort, nous protestons contre l'abus de la force dont notre pays a été la victime.

" $\mathrm{Si}$, dans des temps éloignés et relativement barbares, le droit de conquête a pu quelquefois se transformer en droit effectif, si aujourd'hui encore il réussit à se faire absoudre, lorsqu'il s'exerce sur des peuples ignorants et sauvages, rien de pareil ne peut-être opposé à l'Alsace-Lorraine. . . . En admettant, ce que nous ne reconilaissons pas, que la France ait eu le droit de nous céder, le contrat que vous nous opposez n'a pas de valeur. Un contrat ne vaut, en effet, que par le libre consentement des deux contractants. Or, c'est l'épée sur la gorge que la France saignante et épuisée a signé notre abandon. Elle n'a pas été libre, elle s'est courbée sous la violence, et nos codes nous enseignent que la violence est une cause de nullité pour les conventions qui en sont entachées.

“Vous le voyez, Messieurs, nous ne trouvons dans les enseignements de la morale et de la justice rien, absolument rien, qui puisse faire pardonner notre annexion à votre empire, et notre raison en cela s'accorde avec notre cour. Notre cœur en effet se scnt irrésistiblement attiré vers notre patrie française. Deux siècles de pensée et de vie en commun créent entre les membres d'une même famille un lien sacré, qu'aucun argument, et moins encore la violence, ne saurait détruire." 
"If, in distant and relatively barbarous ages, the right of conquest was sometimes transformed into an effective right, if at the present day again it receives absolution when applied to ignorant and savage people, nothing of the kind can be urged against AlsaceLorraine. . . Even admitting-what we do not recognise - that France was entitled to cede us, the contract which you impose upon us has no validity. A contract, is, indeed, valid only by the free consent of the two contracting parties. Now, it was with the sword on her throat that France, bleeding and exhausted, signed our abandonment. She was not free, she was bent by violence, and our codes teach us that violence renders null and void agreements vitiated by it.

"You see, gentlemen, we find in the teachings of morality and law nothing, absolutely nothing, that can justify our annexation to your Empire, and in that respect our reason is in accord with our feelings. Our hearts indeed feel that they are irresistibly drawn to our French fatherland. Two centuries of thought and life in common create between the members of the same family a sacred bond, which no argument, and still less violence, can destroy."

On the following day, however, Mgr. Raess, Bishop of Strassburg, made a counter-declaration on behalf of View of the himself and his co-religionists to the effect that Bishop of they hadnointention of repudiating the Treaty Strassburg. of Frankfort, which was concluded between two great Powers: "Messieurs, pour prévenir des commentaires fâcheux, qui pourraient nous atteindre, moi et mes co-religionnaires, je me trouve en conscience obligé de déposer ici une simple declaration: les Alsaciens-Lorrains de ma confession n'ont aucune intention de mettre en question le traité de Francfort, 
conclu entre deux grandes puissances. Voilà ce que je voulais dire dès le début."

This counter-declaration called forth the next day a public letter from M. Pouquet, the deputy for Sarreguemines, who stated that the Bishop of Strassburg had spoken in his own name only, and not on behalf of his co-religionists. A warm controversy then ensued in the newspapers published in Alsace-Lorraine. In the Journal d'Alsace of February 2 I a communication appeared from Mgr. Raess, who sought to explain his position and to amplify his previous statement. The following is the principal passage: "As I could not purely and simply regard the Treaty of Frankfort as being of no account, and not wishing to accept it purely and simply in all its consequences, I, in order to preserve an open and free field for the discussion, chose a means and an expression which, whilst respecting the treaty, would not prevent us from bringing out and attacking its deplorable consequences for AlsaceLorraine, and would allow us to remain in the Reichstag to defend our rights and effectively present our grievances and our wishes. Thus I have kept within the Christian and Catholic doctrine which teaches us in its ethical books, in the apostolic constitutions and in the Syllabus (of which every one knows the name and only a few know the contents and value), that an individual may not, at his will, tear up treaties regularly concluded between individuals, towns, and nations. All this does not prove that I have ever been sympathetic towards the annexation of Alsace." 1

At the subsequent elections in I88I, I884, and I887 "protesting" members, as in 1874 , were sent to the

1 Mémorial diplomatique (1874), p. $5_{52}$; F. Klein, L'Évêque de Metz: Vie de Mgr. Dupont des Loges (Paris, 1899), p. 376; cited by Hanotaux, Contemporary France, Eng. trans. (1905), vol. ii. p. 43I, note. 
Reichstag by the annexed provinces, notwithstanding the pressure exercised by the German Government to secure the return of less hostile representaWhy autonomist tives. The régime of repression was accordmovement ingly introduced in good earnest in Alsace-
began.

Lorraine, and germanising measures rapidly multiplied. What with the unsettled state of France and the pacific aims of French democracy, the Alsatians and the Lorrainers came to realise that their hope of liberation from the yoke of the conqueror was vain, and that therefore their only political salvation lay in the establishment of their territory as an autonomous State within the German Empire.

The formula "Alsace for the Alsatians" gradually assumed a wider scope; from the sphere of practical Aim in politics it was imported into the various social and spheres of social and intellectual life of the intellectual life of the people. population. The aim was to preserve their essential characteristics, their own individuality, and their particular cultural aptitudes and aspirations, so that the German attempt at entwelschung might be defeated or neutralised. Some sections of the people devoted themselves to the promotion of national literature, the fine arts, painting, drawing, engraving, design, the decorative arts, architecture, and so on ; the Alsatian plays of Stosskopf, ${ }^{1}$ written in dialect and performed by amateurs, depicted the contemporary life of the provinces. Others rallied round such journals as the Revue Alsacienne Illustrée, which encouraged contact with and sympathy for French culture-not, however, with a view to gallicising the population, but rather to graft on the natural soil such congenial elements as could be extracted from the intellectual, spiritual, and æsthetic 
resources of the former mother-country; for it was recognised that the mass of the people was of a mixed culture, neither French nor German in a distinctive sense. All these tendencies were manifestly opposed to the policy of germanisation, and fostered the spirit of nationalism or particularism.

The method adopted by the nationalist leaders was founded in political opportunism, which at once took cognisance of actual facts and conditions and implied Hence they agreed to establish in the Reichs- alist leaders. tag, as well as in the Territorial Delegacy, alliances with the Catholic centre and the Social Democrats amongst the German parties, for the purpose of attaining certain practical aims, e.g. the removal of the dictatorship, the emancipation of the press, and so paving the way to self-government as the great goal. And these efforts were ably seconded by journalists, humorists, and cartoonists, who set forth the claims of the governed and the ridiculous pretensions, together with the odious practices, of the governing authorities. The fundamental point of view of the active nationalists has been summed up thus: "Whether our aim is possible in our life-time or not, that is not our concern. It is our right, and so it becomes our duty as free men, to speak. A lesson of our history is this. We have endured the Huns, the Vandals, and the Pandours, and Alsace is still Alsace. Let us hope for better days, my children ; for the future, do not forget, belongs to the good God and not to the ugly fellow who presides over the Pangermanist League." 1

In course of time the autonomists became more or less differentiated from the protesters, and a certain antagonism even grew up between them; the latter

1 Quoted by Jordan, op. cit., pp. II3, II 4 . 
remained opposed to germanism and to the German régime, whilst the former were less uncompromising, Differentia- and were prepared to arrive at an accomtion between modation with the Imperial Government, autonomists to act loyally in union with it, and to testers. make the annexed territory a true and genuine constituent of the Empire on the basis of internal selfadministration. This twofold division did not remain throughout clearly defined; political thought could not adjust itself precisely, during the course of its development, to this dual classification. Different parties arose, their groupings and composition being somewhat complicated. ${ }^{1}$

At the elections of I89I and I893 the Socialist party, imported from Germany, made its appearance, Appearance and its activities intensified the political of Socialist struggles and contributed much to modify party. the clearness and simplicity of the former issues. Its immediate purpose was to break up the union of Alsace-Lorrainers.

As a result of its establishment a violent anticlerical campaign was inaugurated; this compelled Anti-clerical the Catholics to form themselves into the campaign. Volkspartei (popular party), which soon became the Landespartei (national party). The latter asserted itself in I896, when, owing to the Reichstag's rejection of the elected candidate, M. Poehlmann, the Kreisdirector of Schlestadt, M. Spiess, the former mayor of the town, offered himself as candidate of the Catholic party and was elected by a considerable majority, in spite of government pressure exercised against him. At this time, too, the Liberal Democratic party, though not yet properly constituted, manifested its existence.

In 1897 the Democrats left the ranks of the Catholic 1 Cf. Wetterlé, op. cit., p. ${ }_{4} 6$. 
party; and after this separation, another distinctive group was established, viz. the Liberals, who were "de nuance gouvernementale," and anti-Catholic. The elections of the following year brought out the rivalries of the various parties and combinations; but on the

Democrats leave the Catholic whole the predominating feeling was hostility to the repressive régime of the Imperial Government. In all these political conflicts religious dissension played a great part; though about 80 per cent. of the population was Catholic, there were among the remainder vigorous Protestant centres in the larger towns. Still, natives and German immigrants combined more and more in their demands for autonomy, which the Imperial Government persistently refused to grant, on the ground (as we have already seen) that the provinces were not yet sufficiently German.

In I9Io was formed the National Union, which contained representatives of various parties, and whose object was to stimulate the native population in favour of the national move- National ment and against the policy of germanisation. formed, The Liberal and Socialist sections, however, offered strong opposition to this new association. The fundamental demands of the autonomists in general have already been pointed out in an earlier chapter. ${ }^{1}$ The complete programme of the National Union of Alsace-Lorraine, which was formally adopted on June 27, I9II, is an elaboration of these demands and is to the following effect:

I. The constitution of Alsace-Lorraine should be that of an autonomous State within the Its proGerman Empire, and should possess all the gramme. rights of a confederated State equally with the other 
constituent States. The guiding motto must be: "Alsace-Lorraine for the Alsatian-Lorrainers."

2. In the work of public administration the officials should speak the languages spoken in the provinces; they should understand and take due cognisance of the intellectual life of the people, their traditions, their customs, and habits. More offices should be given to natives, though vested rights might well be left undisturbed.

3. Taxes and the national expenditure should be diminished; the budget of Alsace-Lorraine should be used mainly in the interests of the population of the territory; and the benefits acquired by the Empire from the railways of Alsace-Lorraine should be shared with them.

4. In the public educational institutions children should be allowed to learn French; family traditions and the traditions of the country should be respected; and books should not be introduced nor lessons given which might cast any disadvantageous or deprecatory reflections on the ancestors of the scholars and their parents.

5. As for the military question, Alsatians and Lorrainers should be permitted to perform their military service in their own province; soldiers should be allowed to speak their own language, and should not be compelled to substitute German for it.

6. The economic questions of the territory should be solved more in its own interest.

7. The national individuality of the country and the people should be respected, and their right to preserve and promote their individuality by every means should be recognised. Regard should be paid to their use of two languages, their relation to two different civilisations, and their desire to remain in 
contact with the literature, arts, intellectual life, sports, and worldly life of the two nations from whom they derive so many of their characteristics. They should be at liberty to visit their friends and relations who emigrated, and the formalities and restrictions imposed on the latter during their stay in the territory should be abolished. They should enjoy the right to pay respect as they thought fit to the tombs of the fallen, whatever flag they fought under. In return for the loyal submission of the people to the order established, they claimed respect for their remembrances and traditions, and the unrestricted liberty to maintain them.

On June II, I9I2, the National Union issued from Strassburg a manifesto directed against the constitution of I9II. ${ }^{1}$ It declared that the imposing of

a new constitution on the people, against $\begin{array}{r}\text { Manifesto } \\ \text { against the }\end{array}$ their will, was a retrograde step, and brought constitution of them no nearer to autonomy; and it demanded that the country should be placed on a footing of equality with the other States of the Empire, for the people did not deserve to be treated as an inferior race. The exceptional situation was intolerable. Hence it was decided to establish a National Party in AlsaceLorraine, with the object of preserving the individuality of the territory and the people, and of acquiring the position of an autonomous State within the German Empire.

It is to be noted that after I9I I the Reichstag parties obtained considerable support from leading Alsatians and Lorrainers, e.g. M. Hoeffel, deputy of Saverne; M. Vondersheer, deputy of Schlestadt; M. Grégoire, deputy of Metz; M. Ricklin, deputy of AltkirchThann. M. Wetterlé severely censures the latter's

1 See supra, p. I 70. 
attitude, which is regarded as having greatly facilitated the Imperial Chancellor's task. ${ }^{3}$ In more recent years the German Government gradually gained over several others of the Alsace-Lorraine leaders; and in I9I7 (as we shall presently see) we find that solemn declarations were made in the Upper and Lower Chambers expressing loyalty and firm adherence to Germany.

In I9I3, again, Alsace-Lorraine asked for " home rule" ; thus, M. Georges Weill, the Socialist deputy

Alsace-

Lorraine asks for

"home rule" in r913. of Metz, pleaded for it in the Reichstag, December 4, I9I3. Whereupon it was argued by some Germans that the demand was made not in the interest of the territory and its population, but simply because of a desire to be on the same footing with the constituent States of the Empire.

At the Social Democratic Conference of Jena, I9I3, the Alsatian Socialists present submitted a resolution Republican claiming for their country republican autoautonomy nomy; this resolution was unanimously conclaimed. firmed on July 5, I9 I4, by the Alsace-Lorraine Socialist Congress held at Strassburg.

There is no doubt that before the present war the memory of I870-I, if not entirely obliterated in AlsaceBefore the Lorraine, had been fast fading. As a recent present war French writer observes": "Il est d'ailleurs memory of trop vrai que, jusqu'à ces derniers temps, fading in AlsaceLorraine. la pensée de l'Alsace-Lorraine et, en général, les souvenirs de I870 avaient grandement perdu de leur puissance sur les masses. Elles avaient appliqué à leur manière le mot malheureux de Gambetta, Il faut $y$ penser toujours et n'en parler jamais. Elles n'en parlaient jamais et n'y pensaient pas davantage."

1 Op. cit., p. 125.

2 Général Palat, L'Alliance franco-allemande ou la guerre (Paris, 1914), p. 133. 
M. Jacques Preiss, formerly deputy for AlsaceLorraine in the Reichstag, and previously one of the most vigorous protesters against the annexation, emphasised in an address ${ }^{1}$ delivered on February I7, I9I3, that his countrymen were strongly opposed to war as a means of settling the question, that they did not desire their rights and liberties to be defended by violence or menaces, and that all they wanted was autonomy. By way of summing up our considerations regarding the autonomist movement and the predominating views that were held by the leaders of political thought in Alsace-Lorraine before the present war, we may set forth the following passages from the address referred to above:

"Alsace-Lorraine wants autonomy. She adopts the motto: 'Alsace for the Alsatians.' She claims to be put on an equal footing with the other parts of the Empire. She wants her own government and her own legislative body, of aims both to be independent in the same degree as those of the Grand-Duchy of Baden, of Mecklenburg, and of the little principality of Reuss, the younger branch. She wishes to govern herself, to regulate her home affairs in her own way, to live her own life, according to her characteristic tastes and traditions. She wishes her particular individuality to be respected, just as that of Baden, Bavaria, and the other States of the Empire is respected. We have the same duties and the same burdens as the other parts of Germany, and we ought in common justice to have the same rights and the same liberties.

"At home no one listens to us, no one understands. That is why we have decided to bring our just claims

1 See Bourdon, L'Énigme allemande, pp. 467 seq.; English trans., pp. $353 \mathrm{seq}$. 
before the pacific tribunal of European public opinion, which has so strongly asserted its great ideas of justice and solidarity with regard to the Balkan peoples. And no one shall hinder us from expressing ourselves wherever we may think it useful and necessary. It ought to be known in the civilised world, that in the centre of modern Europe there is an oppressed people, who, although of an ancient and highly civilised race, and passionately addicted to peaceful industries, is yet deprived of the essential conditions of a normal and honourable existence.

"The German Empire holds Alsace-Lorraine in virtue of the Treaty of Frankfort, concluded between France and Germany. Alsace-Lorraine has never adhered to this treaty. Her word has never been pledged in favour of this treaty. Her consent has always been withheld. Not only has Alsace-Lorraine never accepted or ratified this treaty, but she has formally protested against her cession to and incorporation with Germany. These are the plain and simple facts.

"There are jurists who declare with much learning that all that counts for nothing, that there is no Alsatian question, that it has been definitively settled by the Treaty of Frankfort. Let us leave these good people to their gentle babblings and stick to facts. The protest of Bordeaux and Berlin is an historical fact. This historical fact is so clear, so striking, so dazzling, and so charged with moral significance, that in any case it would need an equivalent act on the part of the people of Alsace-Lorraine, an equally clear, obvious, and open manifestation, showing a will and sentiments entirely opposed, in order to efface it and blot it out of our history. ...

"Let the people of Alsace-Lorraine, then, be con- 
sulted as to their nationality, and, provided they have a free vote, we shall accept this as a sovereign decree. ... Above all written law and formal treaties imposed by force of arms, there is the natural right of a people to decide its own nationality...."

It is to be observed that, in view of the earlier portion of this extract, the later passage as to choice of nationality does not appear to mean a choice as between French and German nationality, i.e. between remaining a part of the German Empire or returning to France, but a choice as between the existing position of the Reichsland and the status of a confederate State of the German Empire, with all the rights of autonomy and self-government. An ardent Alsatian patriot like M. Wetterlé ${ }^{-1}$ holds that this autonomy aimed at is to be only a stepping-stone to another goal, namely, reunion with France; others look upon it as an advance towards the achievement of complete independence. But whether or no this be the real view at present of the majority of the Alsatians and Lorrainers, there is no evidence that such was their view before the present war.

The measures of repression adopted by the Imperial Government and the brutal proceedings of the German officials in Alsace-Lorraine no doubt alienated the people, and turned many of them to France. But there is no doubt also that union with those who in such circumstances turned France? their eyes to their mother-country fully realised that it was powerless to come to their assistance, and that their yearnings and sentiments thus provoked were but a natural, though ineffective, reaction to the oppression suffered by them. Similarly, the 
occasional anti-German outbursts, e.g. in I908 and in I9I3, indicated the hostility of the people to the German régime and the offensive militarism; they were not necessarily manifestations of a widespread determination or even desire to effect a reunion with France. Warm sympathies and cherished recollections connected with France were evoked; but we cannot conclude therefrom that the predominant aim of the people as a whole was to bring about an incorporation with France.

Thus in 1908, in the case of the Noisseville affair, when Count Zeppelin, the Statthalter, authorised the Noisseville erection of a monument to French soldiers affair. who fell at Noisseville, large masses of the Lorraine people assembled to witness the dedication, sang the Marseillaise, and otherwise gave vent to sympathy for their former country. That the Germans were a little alarmed at this manifestation and much more irritated thereby is not surprising; that they determined to tighten their grip on the territory and to wean the people from francophil tendencies by all manner of severe measures is true; but the conclusion drawn from this incident by certain AlsaceLorraine patriots is scarcely warranted.

Again, in I913, in the Saverne (Zabern) affair, when a Prussian subaltern aroused the hostility of the local Saverne population by abusing Alsatians before his affair. men, the general indignation excited was against the insolent and contemptuous attitude of the Prussian military hierarchy, and merely showed that the germanisation of the people was by no means achieved and that their subjection was not acquiesced in. Indeed, it was incidents like this that provoked the disaffection and resistance of the people much more acutely than did the systematic measures adopted 
by the Imperial Government for the purpose of bringing about the entwelschung of the provinces. No wonder, then, that Herr von Jagow afterwards observed, in a letter that was made public: "The officers stationed in Alsace-Lorraine have the impression of living in an enemy country." Officers swollen with arrogance and haughtiness, and nourishing a profound contempt for civilians, will always find themselves in an enemy country wherever there are traditions of liberty and equality before the law.

The Alsatians in general have no leanings towards the neo-germanic culture or to the German political conservatism; they are democratic and Attitude of republican in temperament, and opposed to the people the régime of paternalism, and everything in France and the German polity that savours of the ancien Germany. régime and dynastic loyalism, and demands subservience to officialdom and militarism. ${ }^{1}$ It is the arrogance and persecuting spirit of the conquerors, rather than what is German in itself, that arouse their antipathy and disaffection. The peasantry as a whole concern themselves little with the question whether they are more French or more German, or with the questions of broader politics; they show no enthusiasm for problems of this kind; what they prefer, above all, is to be let alone, to be allowed to go on in their own way, and to be less interfered with in regard to the exactions of military service. They are not really dissatisfied, and not hostile to the German administration, whose thorough and systematic methods they appreciate, as conducing to the agricultural as well as to the industrial progress of the country. On the other hand, the old 
Alsatian and Lorraine aristocracy and bourgeoisie are in favour of French culture and the French language, which they endeavour to maintain despite the ubiquitous restrictions imposed. But there have been numerous defections among the bourgeois classes; more and more of them have associated themselves with the national movement, and have set their minds on national self-realisation as against any possible amalgamation with France. Thus we may say that the intimate feelings of the great majority of the population before the present war can be pretty adequately expressed by the following three lines of current doggerel :

"Français ne peux, Prussien ne veux, Alsacien suis."

(Frenchman I can't be, Prussian I won't be, Alsatian I am). 1

The agitation to return to France was temporary and restricted. The "Ligue Patriotique" established Agitation to in Strassburg, with the object of effecting return to the restoration of the provinces to France, France was contained only a few hundred members, and
temporary

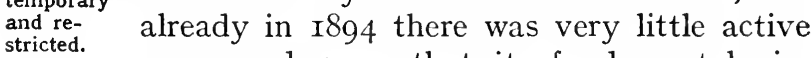
propaganda; so that its fundamental aim assumed the form of a mere vœu, or pious aspiration. Writing in I9I5, MM. Lichtenberger-antiGerman as they are-express a doubt whether the Alsatians, if given the choice, would prefer French to German administration.:

It is necessary to take cognisance of the fact that, notwithstanding occasional anti-German ebullitions, Position of the mass of the people have fallen into line the mass of with the German régime and have taken the people. full advantage of the benefits it offered. To mention but one instance: "Is it not a noteworthy 
sign," asks Karl Blind, " that in these once French provinces-which are situated inland, high up in the south of Germany - the number of seamen, cadets, and officers who have, of their own free will, entered the German fleet should have risen during the last eight years [I884-I902] from I45 to I,750? This number is nearly twice that which would correspond to the number of the population of Alsace-Lorraine, as compared with the remainder of Germany." '

The French Socialist deputy, M. Sembat, who is well acquainted with the popular tide of feeling, doubted in I9I3 whether Alsace-Lorraine was anxious to be restored to France at all. Temper of He points out that, with the passing of time, Lorraine great material and moral modifications have arter forty been brought about in the territory; that the constant influx of immigrants, who are not all detested by the native population, has inevitably made a profound difference. $\mathrm{He}$ emphasises that a distinction must be drawn between the Alsace-Lorraine of to-day and that of $187 \mathrm{I}$, that the temper of AlsaceLorraine forty years after the annexation is not to be judged from the charlatanism of grief of the French boulevards, from the barrel-organ exhibitions of Parisian alleys, or from the myths of café-concerts. "Quelle est aujourd'hui la volonté de l'AlsaceLorraine?" he asks. "Je ne dis pas de l'AlsaceLorraine de I87I, de l'Alsace-Lorraine en deuil, à genoux, éplorée et telle que l'éternisent, en statues de pierre, les sculpteurs patriotes. Je dis de l'AlsaceLorraine d'à présent, de cette région si pleine de vie, si active, si prospère, si industrieuse et qui n'a rien, je vous assure, des allures languissantes et geignardes que lui prêtent les mythes de nos cafés-concerts." 
We must recognise the truth that Alsace and Lorraine, originally different in many respects, acquired

Distinctive personality of AlsaceLorraine. through their common destiny a common spirit, and have developed, in the twentyfive years before the present war, a distinctive personality, and their own particular ideals of nationalism and self-government. Thus AlsaceLorraine is neither French nor German; it is itself. Through the failure to grasp this fundamental point, both France and Germany have in the past made many serious mistakes and have been misled by unfounded assumptions and grave misconceptions. If Alsace-Lorraine has any noticeable affinity with any neighbouring country at all, it is perhaps with Switzerland. ${ }^{1}$

Account must be taken, too, of the fusion between natives and immigrants, and of the rise of the younger Fusion generations in the country. A considerable

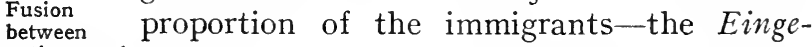
natives and wanderte-are now in the second generation; immigrants. and many of them have contracted marriages with the native stock. It has, indeed, been calculated that over I2 per cent. of the annual number of marriages are "mixed" ; and that 28 per cent. of the children born are either entirely German or the issue of these mixed marriages. It is a mistake to suppose that all these immigrants are bullies, arrogant interlopers, and devoid of all agreeable qualities. Even such an ardent patriot and uncompromising censor of the German régime as Maurice Barrès sees fit to portray a fine immigrant type in Asmus, in his novel Colette Baudoche. Colette marries Asmus; what is her position thereafter with regard 
to the contending claims in Alsace-Lorraine, and to whatever revanche aspirations may be cherished in France? Can she desire war to bring about a liberation of the provinces? The voice of Colette Asmus, says M. Sembat, ${ }^{1}$ has frequently been heard in Mülhausen.

Moreover, the new generation does not regard France as its " patrie" ; nor, indeed, does it, for the most part, regard Prussia or any other State whence the older generation came as its The new vaterland. The Alsatian-born sons of the does not regard immigrants consider themselves as Alsatians ; $\begin{gathered}\text { France as } \\ \text { its "patrie." }\end{gathered}$ and many of them are in fact vigorous leaders in the autonomist movement. They live and think as Alsatians, and speak the Alsatian dialect. ${ }^{2}$ This assimilation by the new environment is more thorough and striking in the case of the sons of the South German immigrants ; for there is a far greater kinship between the latter and Alsatians than between the North Germans and the Alsatians. With regard to the position of this new generation and the question of assimilation, M. André Lichtenberger relates an illustrative anecdote of peculiar significance : At Strassburg two boys-one an Alsatian, the other the son of an immigrant-began to quarrel in the street. "You pig of a Prussian," cried the first. Whereupon the other exclaimed indignantly, "That is not true! My father was a Prussian, but I am an Alsatian."

Furthermore, in our effort to ascertain the true feelings and desires of the people of Alsace-Lorraine

1 Op. cit., p. I60.

2 Cf. H. Albert, in Renaissance latine, October 15, 1903, p. 70 ; referred to by Novicow, op. cit., p. 167 .

${ }^{3}$ Le Matin, March 26, 1911 ; cited by Novicow, op. cit., p. 167. 
as a whole, we must take care not to be misled by various indications of a doubtful character. Doubtful
indications First, there is the question of language, to and desires which reference has already been made.' Of and desires the people. viz. about $2,000,000$ (I,500,000 in Alsace and 500,000 in the annexed Lorraine), it appears Language. that only about one-sixth of them are of French origin or speak French or a French dialect as their mother-tongue. The greater part of the lower classes understand French even when they do not speak it in their homes; whilst the educated classes generally, excepting the immigrants, speak French by preference. Thus before I870, says Karl Emil Franzos, about one-third of the bourgeoisie of Strassburg could speak and write French; another third did not write it, but understood it and spoke it more or less; the remaining third used only the Germanic dialect. But at the beginning of the twentieth century, notwithstanding a long period of German domination, about half of its population speak and write French, whilst a quarter of its population do not know it at all. ${ }^{2}$ Thus French has advanced in many quarters, despite the opposition offered thereto by the governing authorities. Roughly speaking, the boundary between the French and German languages in Alsace follows the summit line of the Vosges. Herr Werner Wittich, a professor at the University of Strassburg, points out that on the whole the upper and middle classes of the towns, as well as the gentry of the country, and the people of the world, prefer French for their usual speech and communication, though they may speak the

\footnotetext{
1 See supra, pp. $38,123$.

2 Cited by Florent-Matter, L'Alsace-Lorraine de nos jours (1908), p. 193.
} 
Germanic dialect to their servants and workmen. We may say, then, that at least four languages and dialects are spoken in Alsace-Lorraine, viz. French, German, a Germanic dialect, and a French dialect (or at least a form of French which differs very much from the standard French of educated Frenchmen). However this may be, we cannot infer from this distribution of languages, or from the preference shown here or there for French, conclusions as to political preference and attachment on the one hand, and aversion and disaffection on the other. For, in the first place, the use of a language is determined by geographical and hereditary circumstances; and, secondly, the preference for French is for the most part due to the preference for French literature, culture, and social life. The international diplomacy of the past has preferred French to German because it was simpler, more elastic, more pleasing, and in all respects more suitable for intercourse, not because the government of the French was preferred to that of the Germans.

Nor can we infer political preferences from the character of the names of the inhabitants. In certain localities, as has already been shown, ${ }^{1}$ Ger- Names of man names predominate; but it may well inhabitants. be that many of these names have deliberately been adopted conformably to the dictates of prudence or the exigencies of business.

Another source of error as to the temper and requirements of the people of Alsace-Lorraine is to be found in the productions of imaginative Novels and literature. Reference has been made to a poetry not a certain novel of Maurice Barrès. But it safe guide. would be altogether unscientific, to say the least, to

1 See supra, p. IIg. 
place too great reliance on the constructive imaginings of novelists : it is not the aim and purpose of novelists and other artists to portray a people, and their circumstances, in general, but only particular characters and situations, which may well diverge far from the so-called average type, and the usual prevailing conditions. M. Barrès depicts in a masterly manner the strength of French sentiment in certain places, for example, in Metz; but he does not deal with the powerful autonomist currents which well-nigh swept aside in many parts of the country the previously cherished French feelings and predilections. Nor are we on surer ground when we consider the passionate outbursts of native poets, such as Edgar Reyle of Metz, who exclaims in his Gloria Victis (Igo8) :

\footnotetext{
"La Patrie, oh! c'est tout! quoi qu'on puisse dire. C'est la mère commune et l'immortel amour; Honte ou mépris à ceux qui la renient un jour!"
}

Again, the outpourings of the chauvinistic journals of the contending parties cannot be regarded as Newspapers. we can readily understand, from our own experience of political journalism and pamphleteering, that the views expressed therein are frequently no more than the views of the individual writers, and are not necessarily shared by considerable sections of the community.

Further, one or two writers have suggested that the fact that children and others in Alsace-Lorraine sometimes exclaim " Vive la France!" serves

Exclamations of "Vrance!" of the people. It may as well be argued that to show the prevailing sentiment and leaning because Englishmen occasionally call out "Good old Ireland!" therefore they are in favour of Home Rule, or prefer Ireland to England. 
Finally, censors of the Germans and partisans of the French have pointed out that the native Alsatian women adopt the fashions of Paris rather than those of Berlin. But do they do so to fasench mark their political preferences or to indicate women. their national grievances? It is not unreasonable to conclude that they do so because the Paris fashions are "smarter" and more becoming.

In conclusion, we may refer to the attitude of Alsace-Lorrainers at the outbreak of and during the present war. The autonomist movement before the war was based on the acceptance of the territorial status quo, and on the recog- at outbreak nition that Germany was capable of pre- of the war. serving it, and that France was and would probably remain powerless to alter it; the Treaty of Frankfort was thus regarded by the advocates of autonomy as incapable of abrogation de facto, and as recording and sanctioning a territorial adjustment which was a fait accompli. But the declaration of war and the accession of powerful allies to the side of France opened a new prospect to many Alsatians and Lorrainers-a prospect that had hitherto existed, if it existed at all, in the margin and not in the focus of their consciousness. It seemed as though the earlier dream of reunion with France might, after all, become a reality; and the steadfast devotees of the mothercountry began once again, and with greater vigour and ardour, to declare their claims to the world.

Several political leaders of the Reichsland went over to France and openly repudiated their allegiance to Germany. The deputy for Metz in the Reichstag, a Social Democrat who had been one of the autonomist leaders, fled to France and announced there that the 
pays messin was looking forward to reincorporation with its former country. M. Blumenthal, the mayor of Colmar, also fled and made a similar announcement in regard to Upper Alsace. The Abbé Wetterlé, a former deputy of the Reichstag and of the AlsaceLorraine chamber, who has recently delivered numerous eloquent public lectures ardently advocating the restoration of Alsace-Lorraine to France, stated in the Écho de Paris, August 2S, I9 I4, that he had been in favour of autonomy because he had neither hoped nor expected that the provinces would be regained by war; but that, war having broken out, the whole situation was thereby at once changed, thus making possible the reannexation of the territory to France.

During the course of the war declarations were made from time to time by representatives of various Alsace-Lorraine societies expressing a wish that the provinces should return to France. ${ }^{1}$ Thus the Ligue Patriotique des Alsaciens-Lorrains, which was established in London in November I9 I4, aims at " a speedy reunion with France, so desirable and necessary for historical and economic reasons," and has issued several pamphlets in support of its object.

Again, after the outbreak of hostilities, many Alsace-Lorraine soldiers have deserted from the German Army. The Paris newspaper, Le Matin, of August 22, I9I7, stated: "The desertions which have taken place since I9I4 in tens of thousands in the regiments recruited in Alsace-Lorraine, the 3,000 years of imprisonment imposed in the space of a year on inhabitants of Alsace-Lorraine suspected of sympathy for France, suffice to illustrate the feelings which the two provinces cherish in regard to Ger- 
many." Similarly, M. Georges Weill, a Strassburg Alsatian who represented Metz in the Reichstag, asserted, in a lecture delivered in Essex Hall, London, November I7, I9I7, that in the few months after August I9I4 more than I6,000 Alsatian-Lorrainers deserted from the German Army. ${ }^{1}$

We have already referred to the German proceedings and rigorous precautionary provisions adopted in the provinces on the eve of the mobilisation and Attitude of after the commencement of the war-the the German preparation of lists of suspects, the restric- authorities tions on free movement and on the use of of the war. French in conversation, the censorship of news, the transportation and internment of many persons of doubtful German loyalty, etc. ${ }^{2}$ That the military authorities were alarmed and were determined to apply the most drastic measures to cases of hostility or disaffection goes without saying. Thus, a Bavarian general is reported to have issued a proclamation, at the time his troops were crossing the Rhine, wherein he observed: "You are entering an enemy country, and you must bear yourselves accordingly." Similarly, the proclamation of General Gaede at Kaysersberg said: "The country pleases me, but its inhabitants will have to be destroyed." '

On the other hand, account must be taken of the pronouncements made in June I9I7 by both Chambers of Alsace-Lorraine affirming their desire to perpetuate their union with the German of the two Empire, and emphasising that what the Chambers, people had before the war been striving for was autonomy within the Empire. Thus Dr. Ricklin,

1 Observer, November I8, 1917.

2 See supra, p. 175.

3 Wetterlé, in Forțightly Review, November 1917, p. 799. 
the president of the Second Chamber, said in the presence of the Statthalter: "The Germans, and in particular we, the inhabitants of Alsace-Lorraine, will never forget that the Kaiser, by proffering the hand of peace, evinced his readiness to put an end to the calamities, moral and material, which have broken in upon our land. We bless every act calculated to abridge the war, were it only for a day, and we put away from us everything which, undertaken ostensibly for the purpose of changing our lot, in reality protracts the struggle, and, together with it, our sufferings. The people of Alsace-Lorraine, in its overwhelming majority did not desire war, and therefore did not want this war. What it strove for was the consummation of its political status in the limits of its dependence upon the German Empire [' in seiner Zugehörigkeit zum Deutschen Reich '], and, that settled, to resume its peaceful avocations. In this respect the war has changed nothing in our country. We make this confession aloud and before all the world. May it be everywhere heard, and may peace be speedily vouchsafed us!"

The speaker of the First Chamber, Dr. Hoeffel, expressed himself to the same effect. The following is the principal passage of his speech: "AlsaceLorraine in particular has felt how heavily the war presses upon us all; but selfless sacrifice is here, too, taken for granted. Our common task has knit the imperial provinces more closely together than before, and has also drawn more tightly their links with the German Empire." '

The Abbé Wetterlé, however, maintains that the above pronouncements are not representative of the

1 These passages are quoted by Dr. E. J. Dillon, in Fortnightly Review, September, 1917, p. 344, referring to the Frankfurter Zeitung, June 10, 1917. 
opinion of the provinces, and therefore do not possess the importance which has been attached to them. He says that before the opening of the spring session, the Imperial Chancellor, Herr von Bethmann-Hollweg, proceeded to Strassburg in order to obtain from the local par-

Whether these declarations are representative. liament declarations of loyalty to Germany, and that he was accompanied by the Socialist deputy, Herr Sudekum, who was to endeavour to win over the extreme left-eleven out of sixty deputies. But they refused to associate themselves with the proposed collective declaration. The Imperial Chancellor approached the bishops of Strassburg and Metz (Mgr. Fritzen and Mgr. Bentzler)-ex-officio members of the Upper Chamber-but could not obtain from them a pledge of attachment in the name of their diocesans. "The bishops thus refused to alienate themselves, by a declaration which would have been severely condemned, from the sympathies of their subordinates." 1 (As to this conclusion we may say, in passing, that it scarcely possesses logical cogency, inasmuch as it involves a begging of the question: for we are not sure whether the declaration would have been condemned, and what the sympathies of their subordinates were.) Further, the same writer points out that Dr. Ricklin is an arriviste and a turncoat, owing his appointment of president of the Second Chamber to the agrarians whose cause he had always espoused; and that Dr. Hoeffel was an opportunist throughout, being one of the senators directly nominated by the Emperor, and that his speeches have not received wide approval. ${ }^{2}$ Apart from this personal stricture it is true that the Upper Chamber, considering its

1 Fortnightly Review, November 1917, p. 796.

2 Ibid., p. 798. 
extraordinary composition,' can hardly be the interpreter of popular views and feelings.

The only fair and safe inference deducible from the above account of the secession of several political Conclusion leaders of Alsace-Lorraine, the declarations of deducible refugees, the precautionary measures of the therefrom.

German Government taken in the territory, the desertions from the German Army, the proclamations of military commanders, the pronouncements made in the territorial Chambers, and the criticism thereof by ardent patriots, is that some people in Alsace-Lorraine were, after the outbreak of the war, desirous of being united again to France, and that others were desirous of remaining within the German Empire, especially if autonomy were conceded to them. What the proportion of these or those people is in regard to the total population cannot be estimated; whether the views of the one side or the other represent the views of a decisive majority cannot be affirmed.

Moreover, we must take into consideration an important factor affecting the determination of these views, viz. the vicissitudes of the war and the expectations of victory on the part of the Allies or the Central Powers. No one can imagine that, in the event of the overthrow of the latter, the native Alsatians and Lorrainers will deliberately and voluntarily choose to continue their association with Germany. On the other hand, are we justified in assuming that, if Germany should eventually triumph, those same people would still prefer to go over to a defeated France? The best way to ascertain the sense of the population is by asking, without threats or pressure, each citizen to express his true sentiments and wishes; and the best time and circumstances in which to ascertain

1 See supra, p. I 70. 
this is not when one or other alliance of belligerents is being worsted or has been vanquished, but when neither side can properly claim an outstanding victory, and when the terms of peace can be arranged by negotiation and compromise instead of being dictated at the point of the bayonet by a victorious belligerent.

Thus it is submitted that the most rational and reliable guidance for settling the destiny of the provinces is to be found in the preponderating opinion and wishes of the population as they were expressed for years before the present war, and not in the uncertain, unnatural, and temporary conditions introduced by the war, nor under the influence of passions and fears engendered thereby. But if it be thought that the sense of the majority of the people may have entirely or substantially altered for good as a result of the present conflict, then it becomes necessary to ascertain it clearly and accurately by means of a justly contrived plan ${ }^{1}$; it would be unfair and unsafe merely to assume that it has changed in a contrary direction. What the desires of the great majority of the people were before the war we have attempted to set forth in the previous pages; by way of supplement we have now to consider the views and feelings in France with regard to Alsace-Lorraine, as they, too, existed before the war and after its outbreak.

1 See infra, chap. xvii. 


\section{CHAPTER XI}

VIEWS AND FEELINGS IN FRANCE AS TO ALSACE-LORRAINE

Three phases of French feeling-Revanche ideal-Evanescence of revanche ideal: contributory causes-Pacific policy of French democracyWhy revanche ideas were passing away-Disturbing currents in France since $187 \mathrm{I}$-France and the question of nationalities-Recent national policy of France-Von Bülow's view of the French temperFrench views after outbreak of the war-British view-Why France determined to recover Alsace-Lorraine-Whether recovery would be "restoration" or conquest-Status of Alsace-Lorrainers in France during the war.

OF the views and feelings in France with regard to the lost provinces there are three phases: first, passionate resentment at the laceration and a deterThree mination to effect a revanche (that is, to French "get even" with Germany); secondly,
feeling.

the evanescence of the revanche ideal; and thirdly, the sudden recrudescence of this ideal on the outbreak of the Great War.

The famous declaration of the deputies of AlsaceLorraine in the National Assembly is said to have Revanche been drawn up by or under the direction * of ideal. Gambetta. The latter, who had proved himself for a space a mighty protagonist in the desperate struggle against the invaders, after the annexation gave utterance to a dictum which has been variously interpreted. His " n'en parlons jamais, pensons-y toujours" has been taken by some people to be a counsel of acquiescence in the accomplished fact. But there is little doubt that he really meant the 
contrary-viz. silent preparation for the day when France would be in a position to make her actions speak louder than her words. Indeed, he emphasised that, failing the deliverance of the captive, there would be no peace in Europe and order and revival in France : " Il n'y aura de paix en Europe, d'ordre et de renaissance en France, que le jour où nous aurons délivré la captive. Préparons-nous sans phrases, et n'ayons jamais d'autre pensée que la reprise de notre bien." 1

Ardent souls like Paul Déroulède gathered round them a League of Patriots and persistently endeavoured to maintain the revanche aspirations in the forefront of the French national life and policy. To men like these, whose longing for restitution was unwavering and all-absorbing, nothing could possibly be an adequate compensation for the territorial spoliation, except the actual recovery of what had been taken away. The acquisition of new colonies could not in their eyes make up for the loss. Thus, Déroulède, putting what he conceived to be his country's indefeasible national duty before all projects of a colonial policy, exclaimed to Jules Ferry: “Moi, j'ai perdu deux enfants; et vous, vous m'offrez vingt domestiques." Similarly, masterly and eloquent writers such as Maurice Barrès did much to nurture and advance the old ideal. These efforts found support at the tribune, in the press, and on the stage.

And so for a long time the wound remained open; grief, rancour, and vows of retaliation were widespread in France, and were common to all parties and all sections of the people. As M. Sembat says: "Des cris déchirants, d'abord, au moment où le fer nous coupa un morceau de nous-mêmes; puis d'éclatantes lamentations, mêlées à des clameurs de haine, et à

1 H. Galli, Gambetta et l'Alsace-Lorraine (Paris, I9II), p. 28. 
des serments de revanche; enfin, de longs et pénibles gémissements, dont le temps assourdit la plainte. Ces cris, puis ces clameurs, puis ces plaintes sortaient de nos cœurs, de tous nos cœurs. Pas un Français, pas un seul, du royaliste au communard, du cagot à l'athée, qui au lendemain de la guerre ne les ait poussés de toute son âme." ' The most poignant element in the disaster that gave rise to this national passion was the fact that France had in I87 I paid for her liberation from the invaders by the sacrifice of a group of her loyal citizens." But we can by no means be certain that, even if the provinces and their population had soon afterwards been restored, France would have ceased cherishing a hope of retaliation, in view of the deep humiliation caused by her signal defeat and the exorbitant ransom of five thousand millions of francs. The history of the world shows that, when one State, relying on its superior brute force, acts unconscionably towards another, it not infrequently sows the wind to reap the whirlwind.

With the passing of time and the economic recuperation and growing prosperity of France, these revanche Evanescence ideals began to lose ground generally; pracof revanche tical-minded people recognised the uselessness ideal. and inexpediency of maintaining their devotion to them, they felt that the lost provinces could never be recovered forcibly by France, which was being overwhelmingly surpassed by Germany in the increase of population and in military and naval armament and organisation. Indeed Gambetta, who died a few weeks before the conclusion of the Triple Alliance was made public, and his opponent Jules

1 Faites un roi, sinon faites la paix (1913), p. I.t8.

$2 C t$. Lichtenberger, op. cit., p. 15. 
Ferry, were disposed to come to an understanding with Germany. In certain limited circles, however, there were still those who adhered to the old ideal, and at every opportunity gave vent to their feelings.

Moreover, various public events, notably in the eighties, stirred up France, and showed that the antiGerman sentiment was but latent, and that contributory the revanche aspirations still possessed some causes. strongholds in the country. In September 1883 Alfonso XII of Spain came to Paris on his way home after his visits to the Austrian and to the German Emperors. When it was announced that the latter had made him colonel of a regiment of Uhlans garrisoned at Strassburg, the taking of which city was being celebrated in an ostentatious manner on the very arrival of Alfonso, protests were made in the Paris press, and the King was hooted as he drove through the streets with President Grévy. At the instance of the Extreme Left, General Thibaudin, the Minister of War, refused to meet "le roi uhlan." In 1886, with the advent of General Boulanger, a more vigorous military policy was inaugurated, which aroused a good deal of enthusiasm in France, and alarmed Bismarck, who, regarding Boulanger as the coming dictator for a war of retaliation, asked the Reichstag for an increased vote for the German Army, and sought to safeguard his country by the establishment of alliances. In April I887 the Schnaebelé incident produced a grave Franco-German tension. The arrest of the French commissary-special, who had stepped over the frontier to effect a certain arrangement with the corresponding German official, was considered an outrage in France, but was justified by Bismarck before the Prussian Landtag in a speech in which he said it was impossible to live at peace 
with so bellicose a nation as the French. The whole proceeding was thought in France to be a trap laid by the Imperial Chancellor, with the object of provoking the French to adopt such a hostile attitude as would precipitate war. On the accession of William II, in the following summer, friendly overtures were made to France, but were not accepted. In February I89 I the young Emperor's mother came to Paris; and her visit to various scenes of German triumph gave rise to an outburst of anger in the French press, which showed that the old fire was still smouldering. Again, anti-German feeling was revealed in France on the conclusion of the Franco-Russian entente in July I89I; and later, in I905, on the occasion of the Franco-German conflict in Morocco. In regard to the latter affair, Mr. Bodley says: "The impression was current in France that Germany wished to give the French nation a fright before the understanding with England had reached an effective stage [the AngloFrench convention had been signed on April 8, I904] ; and it was actually believed that the resignation of Delcassé averted a declaration of war. Although that belief revived to some extent the fading enmity of the French towards the conquerors of AlsaceLorraine, the fear which accompanied it moved a considerable section of the nation to favour an understanding with Germany in preference to, or even at the expense of, friendly relations with England." 1

The mourning figure of Strassburg in the Place de la Concorde of Paris symbolises the abducted daughters of the Vosges; and it is in the presence of the Alsatian maid that the boulevards have continued more or less to cherish dreams of a guerre de revanche, of a guerre d'honneur, and have continued to respond in

1 Art. France, in Encyclopedia Britannica, vol. x. (1910), p. 904. 
their imagination to the traditional call of the patrie mutilee, and to the supposed appeal of the lost children.

But, despite such adventitious and sporadic manifestations, the overwhelming majority of the French people were for a long time before the present war sceptical as to such Alsatian sympathies, and were rather inclined to promote a pacific policy and the democratic interests of the country. And, as has already been pointed out in the preceding chapter, the Alsatians and Lorrainers themselves had long been doubtful as to the capacity, will, or inclination of the mother-country to embark on the perilous adventure of reconquest. Thus the ideals and aspirations which the events of $1870-7 \mathrm{I}$ had brought into being, and which were nurtured for some years afterwards, were beginning on all sides to pass away; and what with the autonomist movement and the era of Young Alsace inaugurated in the annexed provinces, the great majority of Frenchmen began seriously to doubt whether the lost children would be really disposed to return to France, even if they were relinquished by their conquerors. There is a pretty general agreement that Alsace-Lorraine would have been quite satisfied with the status of an autonomous State within the German Empire, and was in any case opposed to war as a means of effecting a solution ${ }^{3}$; so that France came to acquire the reasonable view that she ought to be satisfied, if the provinces themselves were satisfied. And General Palat, writing in I9I4, expresses a widespread view when he says: "Pour notre modeste part, nous croyons que, si l'Alsace-Lorraine était satisfaite de cette autonomie restreinte, nous aurions mauvaise

1 Cf. Sembat, op. cit., p. 162. 
grâce à être plus royalistes que le roi. . . . Cette solution, nous l'accepterions donc de grand cœur." 1

Why were the old revanche ideas passing away? In the first place, as we have just pointed out, because why it was realised that Alsace-Lorraine had been revanche developing an individuality of its own, ideas were
passing away.

German Empire with which it was so closely allied economically, and was very probably unwilling for various reasons (which are to be considered later ${ }^{*}$ ) to be placed under French administration. Secondly, account must be taken of the internal dissensions in France, the disquieting political vicissitudes, and the consequent need that was felt everywhere for securing and cementing the unity of the country on a basis of peace and progress.

It is circumstances such as these, says a recent writer, that kept the question of Alsace-Lorraine dormant in the minds of Frenchmen: "The distracting influence of civil quarrels, colonial diversions, that vague terror of Cæsarism following a successful war which long haunted the diplomacy of the Republic, a widely diffused prosperity counselling comfortable acquiescence, the emasculate theories of internationalists, the fact that the centre of gravity in French politics has shifted to a part of the country which its immunity from invasion and its happy climate predisposed to an amiable materialism-all these causes contributed to keep the question of Alsace-Lorraine dormant in French minds." 's But this dormancy practically amounted, except in a small minority of

1 L'Alliance franco-allemande ou la guerre (Paris, I9I4), pp. I45, I46.

2 See infra, chap. xii.

3 F. Y. Eccles, Alsace-Lorraine (Oxford Pamphlets, I9I 4-15). 
cases, to evanescence, if not to non-existence. These exceptional cases were for the most part the allies of the Royalist and clerical parties; but the mass of the nation, faithful and uncompromising republicans, discountenanced the revanche imaginings for the reason-amongst others-that their effective application would almost inevitably necessitate a revival of monarchical or personal rule. This is the fundamental point of view expounded in M. Sembat's widely circulated publication, to which we have already referred more than once. That the fear, however, was a mistaken one, is proved by the long period of war of incomparable magnitude waged by a united French nation. But would there have been this unity, initial warlike determination, and subsequent fighting persistence if France had not been supported from the very first by some of the mightiest Powers in the world?

It is difficult to give an affirmative answer to this question when we consider the numerous disturbing currents in French public life after the Franco-German Har First of all there were Disturbing the reactionary and monarchical projects France associated with President Macmahon; then came the Boulangist movement, with its futile and paltry heroics, and its speedy collapse; next the Panama affair; the Dreyfus affair, and the antiSemitic movement; anti-clericalism; to all of which being added the uncertain gyrations of foreign policy (from I879 to I894 there were no less than fourteen changes in the office of Minister for Foreign Affairs). The Dreyfus affair - with its revelations of military scandals, the conflict produced between pseudopatriotism and anti-militarism, and the fear of republicans that it involved an attempt on the part of 
the army chiefs to introduce an ultramontane régime in France, whereby Jews, Protestants, and even all liberals were to be excluded from citizenship-intensified the doubt in reasonable men's minds as to the potentiality of the revanche policy, and the wisdom of continuing to talk of a "war of revenge." Moreover, the anti-clerical struggle, produced by the Dreyfus affair, had also a markedly chilling effect on Alsace-Lorraine, with its Catholic population amounting to 80 per cent. of the total number. To all these circumstances must be added this important consideration - the recognition of France that she was being hopelessly outstripped by Germany in the accumulation of armies, warships, and belligerent resources generally; due account must also be taken of such matters as the development of socialism, the gravitation of the Catholic party towards the Centre party, the rise of other parties; and, finally, we must remember the industrial expansion and the emergence of economic questions, together with the indubitably predominating desire of the nation for peace.

Further, as one of the ablest English writers on French public life and thought has pointed out, France in the pre-war period ceased to care about France and
the question the question of nationalities: "It no longer of nation- troubles itself on the subject of nationalities.
alities. Napoleon III, who had more French temperament than French blood in his constitution, was an idealist on this question, and one of the causes of his own downfall and the defeat of France was his sympathy in this direction with German unity. Since Sedan little has been done in France to further the doctrine of nationalities. A faint echo of it was heard during the Boer War, but French sympathy with the struggling Dutch republics of South Africa 
was based rather on anti-English sentiment than on any abstract theory." " The same writer observes that the debates in the Chamber and the Senate on the Separation Bill (which became the Separation Law of December 9, I905, coming into force January I, I906), convinced him that the age of theories and ideas was gone in France." He says that the French nation at the beginning of the twentieth century had undergone a rapid transformation of character. ${ }^{3}$ The electorate were affected chiefly by material concerns; " the strife of conflicting doctrine was assuaged under the more animating influence of material interest." " ".. The idealistic causes which were at work in I830, in I848, and in I87 I are never heard of now. ... The influences, which are now active, to rouse the revolutionary elements in the nation, are the living wage, the working day of eight hours, and the regulation of strikes.... The France of the young century is not the France of the last years of the old."

To these observations may be added the testimony of a leading French historian. Summing up the recent national policy of France, at least till I909, M. Bourgeois says, after pointing out the successful French colonial policy: “. . France has shown great anxiety to associate herself with all the plans concerted between the Powers at the two Peace Conferences of the Hague, and with all efforts to prevent wars by arbitration treaties, while diminishing by international legislation their risks and deadly consequences. The restoration and development of her resources, commercial, agricultural, and colonial, a foreign defensive policy

1 J. E. C. Bodley, art. France, in Ency. Brit., vol. x. (1910), p. 904.

2 J. E. C. Bodley, The Church in France (London, 1906), pp. 5, 7.
s Ibid., p. 5.
'Ibid., p. 9.
- Ibid., pp. IO, 12. 
directed towards the maintenance of her safety and the Balance of Power-these, and these alone, have been her general aims, her instinctive and national policy." " Thus the revanche ideas were fast passing away. Speaking of the military organisation after I87I, and the financial burdens on the people, the same writer observes: "It is evident that the sacrifices, once eagerly undertaken by the nation for its safety, appear less urgent and more burdensome to the more recent generations which have not experienced the danger, and are not actuated to the same degree by the bitterness of defeat and the desire of revenge." "

In concluding this section of the chapter we may set forth the remarkably different estimate of French aims and attitude recently made by Prince Bernhard von Bülow, Imperial Chancellor, I904-9 :

"The resentment against Germany might well be called the soul of French policy; the other interVon Bülow's national questions are more of a material

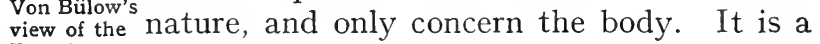
French peculiarity of the French nation that they
temper.

place spiritual needs above material ones.

"The irreconcilability of France is a factor that we must reckon with in our political calculations. It seems to me weakness to entertain the hope of a real and sincere reconciliation with France so long as we have no intention of giving up Alsace-Lorraine. And there is no such intention in Germany. There certainly are many individual points in which we can see eye to eye with France, and in which we can cooperate, at any rate, from time to time. We must always endeavour to preserve polite, calm, and peaceful relations with France. But beyond that we should

1 E. Bourgeois, The Third French Republic, in Camb. Mod. Hist., vol. xii. (1910), chap. v. p. 133 .

2 Ibid., p. 97. 
not pursue any will-o'-the-wisp delusions, otherwise we may meet with the fate of the astronomer in La Fontaine, who, while gazing at the stars, fell into the pit which lay at his feet, but which he had not seen. In this case the pit is called Le trou des Vosges.

"Also, as regards France, we must not hope too much from attentions and amenities-the small change of international intercourse. In saying this we do homage to the proud patriotism of a great nation. The resentment against Germany lies too deep in the hearts of the French for us to be able to overcome it by cheap expressions of friendship. France was never so hard hit, not even after the catastrophic defeats of $\mathrm{I} 8 \mathrm{I} 2-\mathrm{I} 5$, as by the war of I870-7I. In France there is no comprehension of the fact that what seems to them the brutal severity of a conqueror was really a matter of national necessity to us Germans. Perhaps in course of time the French nation will grow reconciled to the decisions of the Peace of Frankfort, when it realises that they were and are irrevocable. But so long as France thinks she perceives a possibility of winning back Alsace-Lorraine, either by her own unaided efforts or with the help of others, so long will she consider the existing arrangement provisional and not final.

"The French have the right to claim understanding for this feeling with which the majority of the people are deeply imbued. It is a proof of a lively sense of honour if a nation suffers so keenly from a single injury to its pride that the desire for retribution becomes the ruling passion of the people. It is quite true that for many centuries France was responsible for the spirit of unrest which troubled the history of Europe. We had to fortify our position in the west in an enduring manner, so as to safeguard our peace 
from fresh disturbances. The remedy has not been altogether unavailing, not only so far as Germany is concerned, but for the whole of Europe. . . . We wish to prevent the return of such times as those of Louis XIV and of Napoleon I, and for our greater security have therefore strengthened our frontiers against France.

". . . The policy of revenge is supported by the unshakable belief of the French in the indestructibility of the vital power of France. This belief is based on all the experiences of French history. No nation has ever recovered so quickly as the French from the effects of national disasters; none have ever so easily regained their elasticity, their selfconfidence, and their energy, after grievous disappointments and apparently crushing defeats. . . .

"When we consider our relations with France, we must not forget that she is unappeased. So far as man can tell, the ultimate aim of French policy for many years to come will be to create the necessary conditions, which to-day are still wanting, for a settlement with Germany with good prospects of success. If we soberly realise this truth, we shall be able to adopt a proper attitude towards France. Indignant tirades against the incorrigibility of the French are in very bad taste, as are futile attempts to propitiate them. The German 'Michel' has no need again and again to approach the coy beauty with flowers in his hand; her gaze is riveted on the Vosges. Only an acceptance of the irrevocability of the loss of I87 I can accustom France finally and without restriction to the state of affairs fixed in the Peace of Frankfort. ..."'

The above statement of the German ex-Chancellor

1 Imperial Germany, English translation (London, 1914), pp. 70-74, 86. 
needs little comment. It is obviously an entirely erroneous estimate, and an extraordinary misinterpretation of occasional and sporadic revanche His estimate manifestations as constituting the national erroneous. policy of France. There is no doubt that pronouncements like this are meant to serve as a justification to the German people of the German Government's military and naval preparations and as a blind-for Europe in general-to cover the instinctive and insuperable aggressiveness of the pangermanists and the German military classes. The essential facts are that Germany had long been preparing for war, that she was a nation armed to the teeth and fully equipped in every conceivable manner, that she was ready to strike anywhere at a moment's notice, that her military projects were prearranged in every detail and were to be carried out according to programme; that France did not desire and was not prepared for war, and that she indeed took up arms in August I9I4, not because she wanted to recover Alsace-Lorraine, but because she was obliged to protect herself against this German aggressiveness, and was anxious to remove the constantly growing German menace which made life on the Continent well-nigh unbearable. To what extent the old revanche ideas and feelings were revived after the war had thus been precipitated we have now to consider.

At the session of the French Chamber, August 4, I9I4, M. Viviani made but a brief allusion French views to Alsace-Lorraine: “ L'Allemagne n'a rien as to Alsaceà nous reprocher. Nous avons consenti à la after outpaix un sacrifice sans précédent en portant break of the un demi-siècle, silencieux, à nos flancs, la blessure ouverte par elle." 
In November I9I4 General Joffre said at Thann to the Alsatians amongst whom he found himself: " Notre retour est définitif, vous êtes Français pour toujours. La France apporte, avec les libertés qu'elle a toujours représentées, le respect de vos libertés à vous, des libertés alsaciennes, de vos traditions, de vos convictions, de vos mœurs. Je suis la France, vous êtes l'Alsace; je vous apporte le baiser de la France."

This declaration was confirmed by President Poincaré at Saint-Amarin, February I2, I9I5: " Je viens confirmer aux populations d'Alsace les déclarations que leur a déjà faites le général Joffre. La France, heureuse d'ouvrir les bras à l'Alsace si longtemps et si cruellement séparée d'elle, ne doute pas que la victoire n'assure bientôt la délivrance des provinces qui lui ont été arrachées par la force; et tout en respectant leurs traditions et leurs libertés elle leur rendra leur place au foyer de la patrie."

On December 23, I9I4, at an extraordinary session of the Chambers, it was proclaimed that France was determined to fight on and not lay down arms until the outrage of I87I was avenged and the provinces torn from her by force were reunited to her.

Similarly, M. Viviani, in the Chamber of Deputies on February I8, I9 I5, reaffirmed the resolve of France to prosecute the war " jusqu'à la libération morale de l'Europe," and demanded the return of Alsace-Lorraine: "Depuis quarante-quatre ans, messieurs, d'une façon permanente et plus vivement, j'allais dire plus tendrement depuis le début des hostilités, l'AlsaceLorraine, sous toutes les formes, a manifesté son attachement au foyer français. Elle a préparé ellemême, par son héroïque fidélité, le retour à la patrie mutilée, si bien que, lorsqu'au jour venu, nous pourrons 
pour ainsi dire resserrer les bras autour d'elle, nous pourrons dire qu'elle nous est revenue non pas par le fait d'une conquête, mais d'une restitution." In regard to such pronouncements as this, we may say that France may have justifiably held that she had a moral right to endeavour to recover the lost provinces; but we must add, with all due submission, that, conformably to the evidence adduced in this chapter, the claim as to Alsace-Lorraine having all along prepared itself for reunion to France can scarcely be substantiated.

On June 5, I9I7, the French Chamber of Deputies adopted the following resolution by 453 votes against 55: "Contresignant la protestation unanime qu'en I87 I firent entendre à l'Assemblée Nationale les représentants de l'Alsace-Lorraine, malgré elle arrachée à la France, elle déclare attendre de la guerre, qui a été imposée à l'Europe par l'agression de l'Allemagne impérialiste, avec la libération des territoires envahis, le retour de l'Alsace-Lorraine à la mère patrie et la juste réparation des dommages." The following day the French Senate too declared amongst the aims of the war " la restitution de l'Alsace-Lorraine." 1

In a government statement made in the Chamber by M. Painlevé on September I8, I9I7, it was said that "if France pursues this war it is neither for conquest nor vengeance," and one of her aims was proclaimed to be "the disannexation of AlsaceLorraine." :

The following day M. Ribot, the Minister for Foreign Affairs, said: "We did not enter the conflict with

1 Bulletin des informations parlementaires. Publications du parlement interallié. (No. I. I ${ }^{\mathrm{r}}$ juillet, I9I7.)

2 Daily Telegraph, September 19, 1917. 
warlike designs. For forty-five years we desired peace, notwithstanding the bleeding wound in our side. And to-day, after all the French blood that has been shed during this long struggle which was imposed upon us, what do we want? Justice. France does not wish to do violence to any one. She only demands justice... When we demand before the world the restoration of Alsace-Lorraine, we are the champions of violated right, and we claim from the world the indispensable preface to a durable peace, namely, reparation for the injustice which was done forty-five years ago, and which for forty-five years has weighed upon the world. If that is not done, nothing is done. (Loud cheers.) It would merely mean a truce for some years; whereas we shall not have made all our sacrifices in vain if we found peace on what is eternal-on justice and right." " same minister observed on October I2, I9I7, that an agreement by Germany to restore Alsace-Lorraine to France is " a condition precedent to a peace founded on justice," and he added: "There would be no peace which would guarantee our children from a renewal of such a terrible war, if the injustice of Alsace-Lorraine were not repaired." ?

From time to time various other political leaders, such as M. Barthou, and more recently M. Clemenceau, have expressed themselves to the like effect. And in every case the idea of holding a plebiscite to determine the wishes of the population concerned was repudiated-when it was mentioned at all-as being at once unnecessary and in the circumstances insulting.

The French Socialist party, however, recognised the expediency and justice of resorting to a referendum on the ground that all oppressed populations were

\footnotetext{
1 Daily Telegraph, Sept. 21 1917.
}

2 Times, October I5, 19I7. 
entitled to determine their own destiny, and held that the question of Alsace-Lorraine was not a purely territorial question, but a question of right. At the Congress of December I9I 5 the following resolution was passed by 2,759 votes against 72 and 92 abstentions: "Pas de paix durable sans que soit rendue aux populations opprimées de l'Europe la libre disposition d'elles-mêmes et sans que soit rétabli entre la France et l'Alsace-Lorraine, au nom d'un droit que le temps n'a pas prescrit, le lien que la brutalité de la force avait seule tranché en I87I, malgré la protestation socialiste de Bebel et de Liebknecht au sein de la nation allemande elle-même. Ce droit établi, la France saura se montrer prévoyante et juste en demandant à l'Alsace-Lorraine elle-même d'affirmer à nouveau, solennellement, comme le firent ses représentants à l'Assemblée de Bordeaux, sa volonté d'appartenir à la communauté française."

There is no need to give more references to the numerous and repeated French declarations on the subject, which have been consistent and British unanimous. This openly expressed aim of view. France was accepted by the British Government and by authoritative spokesmen here, who have more than once declared their determination to support France so long as she laid claim to Alsace-Lorraine. Thus Mr. Lloyd George, the Prime Minister, said on October II, I9I7: "However long the war may last, however great the drain upon our resources, this country intends to stand by her gallant ally France until she has redeemed her oppressed children from the degradation of a foreign yoke." ' At the beginning of I9I8, however, the Prime Minister made use of markedly modified expressions, when he said that the

\footnotetext{
1 Daily Telegraph, October 12, 1917.
} 
Alsace-Lorraine question will have to come up for " reconsideration," along with other territorial questions, at the peace negotiations. And President Wilson expressed himself to the same effect.

We see, then, from the above pronouncements that France's resolve to recover the lost territories is based Why France on four main grounds-(I) to wipe away the determined bitter humiliation of having been forced to to recover surrender a portion of her country and
AlsaceAlsacepeople contrary to their will, (2) to vindicate right and justice, (3) to give effect to the longings of the "lost children," and (4) to ensure the maintenance of European peace. The first reason is of course perfectly intelligible, and commends itself to all who possess any self-respect ; the second is also admissible if it be construed in the sense of moral right and justice, for-as we have shown in an earlier chapter ${ }^{1}$ - the legal right and justice in regard to the possession of Alsace-Lorraine is undoubtedly on the side of Germany in the eye of international law and usage, through the sanction of the deliberately concluded Treaty of Frankfort; the third is questionable, as we have already been obliged to infer from ample evidence; the fourth reason is much more questionable.

With reference to these grounds suggested in the French claim, two points need to be emphasised-for we must ever be mindful of the fact that

Whether recovery would be " restoration " or conquest. the Allies have from the first been fighting on behalf of law and order, and have repeatedly protested against the signal violations of international law committed by the Germans. In the first place, the French and others hold that the return of Alsace-Lorraine to France

1 See supra, pp. 149 seq. 
would be a "restoration" and not a conquest, and that the provinces have never formed part de jure of the German Empire. Secondly, it is contended that the German declaration of war in I9I4 ipso facto abrogated the Treaty of Frankfort. The second point we have already dealt with, and have submitted that the contention is legally untenable. ${ }^{1}$ As to the first point, we may say, briefly, that if Germany consents to return the provinces before the Allied forces have militarily occupied them, have ousted the Germans from them, and have determined to take them away permanently, such return will amount to a "restoration" in the proper sense of the term; but if Germany is compelled, through the military occupation by her opponents, to give up the territory, then the acquisition by France thereof is a result of conquest and annexation. Accordingly, if the formula "no annexation" is accepted by the belligerents, it necessarily implies that Germany is to retain Alsace-Lorraine.

Finally, a word must here be said regarding the status of Alsace-Lorrainers in France during the present war. If it be true that they (i.e. the annexed people and their descendants, Status of not the German original inhabitants and Lorrainers immigrants) have always desired to return during the to France and that they have never ceased to be Frenchmen at heart, it follows that the moment they set foot on French soil they should be treated as Frenchmen and not subjected to discriminative regulations. Thus M. Helmer says that, in view of the Alsatian protests before the National Assembly at Bordeaux and the attitude of the population of the provinces for forty-four years, the "annexés" ought 
to be considered simply as Frenchmen, even before the reunion resulting from victory. ${ }^{1}$ Similarly, M. Barrès observes in the preface to the latter's book: "Il ne peut y avoir de doute que, même durant cette guerre et avant la réunion qu'amènera la victoire, les annexés doivent être considérés comme des Français." " The actual facts, however, do not correspond to these views. Whilst the "annexés" do not appear to be treated in France exactly like alien enemies, yet the régime applied to them-e.g. the insistence on the use of permits for residence, their internment, and various other restrictions-constitutes such a discrimination as amounts practically to a denial of their alleged status. "Décidément," observes M. Helmer, "la situation des Alsaciens n'est vraiment pas enviable."' 3 No doubt precautions must be taken in these days. Whether or not it is expedient to do so, the actual treatment in France of the " annexés" and the theoretical claims advanced on their behalf are obviously incompatible.

Having already given an account of the nature of the Alsace-Lorraine question, the character of the country and people annexed, their history, the annexation in $187 \mathrm{I}$, the claims of Germany to the provinces, the German régime therein, the views, feelings, and national movements in the Reichsland, the views and aspirations of France before and after the outbreak of the present war, we have now to address ourselves to our concluding task, viz. to examine the suggested solutions of the question and to show which it is best to adopt in view of the present complicated circumstances and conflicting claims and interests.

1 P. A. Helmer, France-Alsace (Paris, n.d.), p. 123.

2 Ibid., p. $\mathbf{x}$.

3 Ibid., p. It 2. 


\section{CHAPTER XII}

\section{SOLUTIONS SUGGESTED: (a) REANNEXATION TO FRANCE}

Reannexation followed by referendum suggested-German pronouncements as to Alsace-Lorraine-Forcible reannexation not a true solution; inherent difficulty-Various other difficulties: Frontier-Grouping of Alsace-Lorraine within political framework of France-The language question--The legal system-The industrial organisation-The commercial system-Fiscal legislation-The religious question--The educational system-Position of immigrants and the younger generationThe previous nationalist movement-Other difficulties. Interregnum suggested for smoothing over difficulties.

ONE of the solutions suggested as a settlement of the Alsace-Lorraine question is the reannexation or retrocession of the territory to France. This reannexation may assume one of two forms: it may be a forcible recovery, consecrated by the treaty of peace, as a result of a sufficiently decisive victory enabling the Allies to dictate terms; or it may be a voluntary cession on the part of Germany before such victory be gained. Each case assumes the willingness of the population of Alsace-Lorraine to accept and abide by the result. For the present we may eliminate this element of willingness or opposition, as we shall consider it later.

Reannexation, without being made subject to this latter qualification, has been advocated and claimed by many. Reference has already been made Reannexato the official French and British views. tion followed Some Frenchmen-for example, M. Albert by referenThomas, ${ }^{1}$ the well-known Socialist-have gested. brought forward a modified proposal, viz. that first

\footnotetext{
1 Times, Jan. 22, 1918, p. 5.
} 
the territory should be returned to France, and afterwards a referendum should be organized " under the ægis of a society of nations," for ascertaining the will of the population thus transferred. The intention here is obviously on the one hand to atone as far as possible for the wrong done to France in I87I, and on the other to apply the principle of the selfdetermination of populations - a principle that has recently been more than ever emphasised.

The main difficulty to be overcome is the opposition of Germany; for we cannot suppose that she will restore the territory voluntarily. The Germans are just as determined to hold Alsace-Lorraine as they are to hold Berlin. To overcome this determination by force of arms will mean to break the Central Empires into fragments and to annihilate the Germanic population. To achieve such a result would necessitate such unspeakably appalling slaughter, destruction, and sacrifice on all sides as would leave Europe a shambles and without any population at all. Is the result worth the cost? Only an unreasoning fanatic could answer this question in the affirmative.

However shallow and insincere German pronouncements in general may be, there can be no doubt that German de- the reiterated declaration not to give up termination Alsace-Lorraine is meant in grim earnest. and pro-
nounce- Thus Baron von Kühlmann, the Foreign

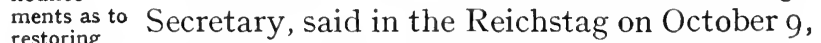
restoring

Aisace-

Lorraine. I9I7, in reply to Mr. Asquith's speech at Leeds, September 26, I9I7, asking whether Germany was ready to restore what she took away from France in $187 \mathrm{I}$ : "There is but one answer to the question-Can Germany in any form make any concessions with regard to Alsace-Lorraine? The answer is, No, never. So long as a single German 
hand can hold a gun, the integrity of the territory handed down to us as a glorious inheritance by our forefathers can never be the object of any negotiations or concessions. I am sure that, whether on the Right or on the Left, you will stand for that with equal resoluteness and equal self-sacrifice. I am not of those who think that a candid statement of such a fact might be detrimental to the rise of a clear and sincere will for peace. On the contrary, I think such a will can only prosper and be fruitful on a ground of absolute clearness. Therefore I think it necessary to state emphatically, with all possible conciseness and clearness, as against all other questions which have of late so markedly come to the fore in public discussion, and which have taken up so much space, that what we are fighting for, and will fight for to the last drop of our blood, is not fantastic conquests, but before all the integrity of German soil." 1

Similarly, a little later during the Kaiser's visit to Rumania, he is reported by the Nene Freie Presse of Vienna to have remarked in regard to M. Painlevé's speech in the French Chamber: "The maiden speech of the new French Premier has just been brought to me. So M. Painlevé wants Alsace and Lorraine again? Good! He can fetch them." "

In I88 I the Emperor William I said: "Germany would leave her eighteen army corps and her 42,000,000 people on the battle-field rather than surrender a single stone of the territory won in $1870 . "$

It is of interest here to recall a statement made a year before the outbreak of the present war by the Berlin Professor of History, Dr. Hans Delbrück, who emphasised the absolute impossibility for Germany to

\footnotetext{
1 Daily Telegraph, October II, I9I 7.

2 Ibid., October I9, I9I7.
} 
give up the provinces or exchange them for other territory, and gives various reasons (which have already been dealt with in preceding chapters) why she insisted on the cession in I87 I and why she must retain them. He said to an interviewer that it was a mere waste of time to discuss the question of restoration; and he is reported to have expressed himself to the following effect: " I can conceive of no other single question within the scope of international politics, with the possible exception of disarmament, on which the German nation would chorus a more thundering 'No,' than of surrendering the conquered provinces. Alsace-Lorraine's connection with the Empire is the very last word of irrevocability. We might as well be asked to surrender Prussia as to give up the territory bought and paid for at Gravelotte, Mars-la-Tour, St. Privat, and Sedan. Restoration of Elsass-Lothringen is not debatable for us in any form whatever. No proffer of territory in exchange anywhere on the face of the globe could induce the German Government even to consider such a transaction. The anti-German sentiment there is a nebulous and vanishing force. It is kept up for the most part by clerical agitators. Compare the condition of the Roman Catholic Church in France and in Germany, and you will find, with me, that it is very likely that these men would be just as anti-French as they are now anti-German were the tricolour to supplant the black-white-red of Imperial Germany. Alsace-Lorraine now has a parliament of its own under a constitution which grants the inhabitants of the provinces the maximum of political liberty and self-government. ${ }^{1}$ France is confined to Metz and the adjacent frontier regions. Alsace and Lorraine were German long

1 We have seen in chaps. $\mathrm{ix}$ and $\mathrm{x}$ that this was not so. 
before they were French. Our folk-song literature is replete with songs of Strassburg. ${ }^{1}$ Goethe attended the University there. When we took Alsace-Lorraine in $I 87 \mathrm{I}$, we regained what was our own. Why did we retake it? Because the safety of German territory demanded it. France openly coveted the left bank of the Rhine. What else was the real underlying cause of Napoleon's war? Alsace-Lorraine had to be taken if that part of our fatherland west of the Rhine was to be permitted to develop in peace and safety as an integral part of the German nation. Sir Joseph Compton Rickett tells us that the restoration of Alsace-Lorraine would be the end of revanche.... It would be the very beginning. The French would say: 'If the Germans are supine enough to abandon Alsace and Lorraine, they will not be strong enough to resist pressure still further east.' Our defensive position, instead of being stronger, would be incomparably weaker after we had scuttled out of Metz and Strassburg. We should be in exactly the same perilous military situation as we were in before 1870 . This is a state of things not even the most rabid Social Democrat would tolerate. . . . It would be a pitiable politician and a sorry strategist who would begin putting the national house in order for the great emergency by abandoning the "watch on the Rhine.'

One more German view may be referred to-that of Maximilian Harden. Writing early in I9I6, he said : "If people think in France that the re-establishment of peace is possible only through the restitu-

\footnotetext{
1 "O Strasburg, meine Strasburg

Du wunderschöne Stadt,

Die seit zwei hundert Jahren

So viel gelitten hat."

2 Daily Mail, August 20, I9I3.
} 
tion of Alsace-Lorraine, and if necessity compels us to sign such a peace, the seventy millions of Germans will soon tear it up."

Many Germans are fond of enlarging on the argument, referred to by Dr. Delbrïck, that their country The German paid with its blood for the acquisition of the argument
that the territory. To retrocede Alsace-Lorraine, they annexation say, would be an act of treason committed was paid for against those who died for the fatherland. man blood. But a plea of this kind is untenable; it is very nearly like saying that, because a burglar lost his life in taking another's property, therefore the ownership of the property must not be questioned when it is found in the hands of the burglar's sons or associates. Because our forefathers have shed their blood for an error, asks Novicow, must we persevere in that error? To do so would mean to do evil to the living in order to please the dead. Fidelity to the ideas of ancestors, if these ideas were or have become false, is obviously an anti-social attitude. The ancestors of the present Germans burnt witches; is that a reason why the Germans of to-day should do so? This is not the way, says the last-mentioned writer, to acquire a "place in the sun": it is possible to fight and kill and steal for the purpose of acquiring a place in the sun, and yet actually live in a fog. ${ }^{1}$

However little importance be attached to such German pronouncements and arguments as those set Difficulty inherent in forcible retrocession of Alsace-Lorraine to solution by forcible re- France cannot be a true solution; for a true annexation. solution necessitates an amicable accommodation and voluntary agreement of the parties con- 
cerned. In the present case there are: France, Germany, Alsace-Lorraine, and the rest of Europe (more correctly, perhaps, the rest of the civilised world). If, by reason of a decisive defeat, Germany felt constrained to abandon the territory, her resulting grievance would be a far greater menace to the peace of Europe than the grievance of France proved to be after I87I; a society or partnership of nations together with disarmament agreements could not then possibly be established; the existence of a festering sore in the very heart of Europe would render impossible frank and healthful international relationships, and would perpetuate those sinister shadows, suspicions. and fears which it is the business of a salutary régime to remove and prevent.

Moreover, in addition to this great difficulty attending a forcible restoration of the provinces there are various other difficulties that are incidental both to this kind of annexation and to $\begin{gathered}\text { various } \\ \text { other }\end{gathered}$ amicable cession. Many simple persons be- difficulties. lieve, says M. Wetterlé, that nothing is easier than the reassimilation of Alsace-Lorraine to France, that French legislation may at a single stroke of the pen supersede the existing German legislation, that French officials may immediately supplant the existing German officials, and that, generally, a transformation may at once be effected as by a magic wand. Ardent enthusiast as he is for the restoration of the territory, this Alsatian patriot cannot but admit that the problem is a very complicated one, that the long period of German régime, legislation, organisation, and systems have set up an ever-widening barrier between France and Alsace-Lorraine, and have caused their habits, customs, and interests to diverge-." s'éloignant touI6 
jours davantage l'une de l'autre et créant dans deux populations, qui avaient perdu tout contact administratif, des habitudes, des mœurs, des intérêts divergents." 1

The return of Alsace-Lorraine to France within its geographical limits as existing before the FrancoFormer German War would, of course, mean a frontier restoration of the former boundary between untenable. France and Germany-a defective boundary that proved such a stumbling-block to the two nations and was more than anything else responsible for the outbreak of the war of $1870 .^{2}$ Strassburg and Metz were, in German eyes, sally-ports into Southern Germany, which therefore felt itself to be at the mercy of French artillery and French invaders. The fact that after their transference to Germany they became sally-ports into France shows that the frontier arrangement of 187 I was defective, not that the frontier existing before then was good; so that to substitute the former boundary for the present one is merely to substitute one evil for another. The truth is, indeed, that it is not so much faulty boundary adjustments that prove to be intrinsically disastrous and fatal, as the accumulation of armament and territorial lust. However this may be, the point we would here urre is that the retrocession of AlsaceLorraine to France would involve the very serious disadvantage of putting back again an untenable line of demarcation between the two countries.

If the provinces were returned to France, how would they be grouped within her political framework? Before the cession of I87 I they comprised three departments-Haut-Rhin, Bas-Rhin, Moselle with parts of Meurthe. Considering the development of an 
Alsace-Lorraine personality and national individuality during the last half-century (as has already been shown), ${ }^{1}$ would it be a satisfactory and ex- Grouping pedient arrangement to split the territory $\begin{gathered}\text { of Alsace- } \\ \text { Lorraine }\end{gathered}$ again into three minor departments, and, in $\begin{gathered}\text { Lorraine } \\ \text { within }\end{gathered}$ view of the profound divergences that prevail, framework to reinstate them in a country where govern- of France. ment and administration are so highly centralised? Alsatians and Lorrainers have long held that a status of this kind would be most undesirable, if not practically impossible. What other bonds of incorporation could be established? The fundamental difficulty is due to the conflict between the principle of centralisation, and the principle of self-government for which the people have long been striving and preparing themselves. MM. Lichtenberger observe that, as Upper and Lower Alsace have many affinities and common interests, it would be desirable to maintain the existing Alsatian unity, and effect a division into two departments, Haut-Rhin and Bas-Rhin, to which the country would soon accommodate itself." The advocates of reannexation, whilst usually admitting the great difficulties involved, are too much disposed to gloss them over with a stroke of the pen, and to say glibly and in an off-hand manner, that a proper political adjustment would soon be effected, that a satisfactory accommodation would soon be arrived at, and so on.

The language question is another obstacle. We have already pointed out that the great majority of the population speak a German dialect, and that in many parts of Alsace-Lorraine language French is neither spoken nor even known. question. M. Wetterlé himself admits that the working classes

\footnotetext{
1 See supra, chap. $\mathrm{x}$.
}

2 op. cit., p. 89. 
generally, who constitute the greater part of the people, now speak no other tongue but their German patois - " en étaient arrivés à ne plus parler que leur savoureux dialecte." ' It is difficult to imagine that France would agree to adopt such a policy as was provided by Article $\mathrm{V}$ of the Peace of Vereeniging, May 3I, I902, whereby Great Britain consented that Dutch should be taught in public schools in the Transvaal and the Orange River Colony, if the children's parents desired it.

The substitution of French law for the existing German legal system would be attended by many The legal serious disadvantages. It is obvious that, in system. case of reincorporation, the German law could not remain permanently; at most it could be allowed to remain in force for a given period-for the purpose of making the transformation gradual and interfering as little as possible with the vested rights, the executory contracts, and the material and moral interests in general of the population, just as Germany allowed French legislation to continue for a limited period after the annexation in $187 \mathrm{I}$, before introducing the imperial law. Owing, however, to the much more developed state of the country at present, the period permitted would have to be of very considerable length, during which the various intimate relationships between France and the acquired territory would be made difficult. With regard to this change of public institutions and law, MM. Lichtenberger remark that the problems as to when French law should be resumed, how far German law should be retained and necessary exceptions introduced, or whether French law should be introduced with special exceptions, must all be solved "avec discernement et sans parti-pris" ";

$$
1 \text { Op. cit., p. } 292 .
$$$$
2 \text { op. cit., p. IIr. }
$$ 
that for the law of real property and mortgages a transition stage is indispensable; that the various associations, such as limited companies, co-operative societies, commercial registers, should be preserved; and that throughout " il faut procéder avec tact, et mesure." I It is, therefore, evident that very tight knots will be met with in all these matters. ${ }^{2}$

The industries of the provinces have undergone, under the German régime, a complete transformation ; and their products go for the most part to German purchasers and consumers. The indusGerman purchasers and consumers. The trial or-
labour legislation has been systematic and ganisation. comprehensive, and either differs considerably from or has no counterpart in French legislation. In the case of the working classes German social legislation is admittedly far more progressive than the French ${ }^{3}$; they enjoy benefits that are beyond the reach of the French proletariat, and great numbers of them have warmly espoused the social democratic cause. The insurance schemes for workmen have proved to be most beneficial, and, as M. Wetterlé himself admits, they have created rights " qui ne sauraient être écartés d'un geste dédaigneux." " Nearly all the German immigrants, with the exception of the officials of the country districts, are found in the towns: thus the 60,000 immigrants of Strassburg form about 35 per cent. of the total population of the city; in Metz there are some 36,000 immigrants as against 30,000 natives, that is 55 per cent. of the population; and in the mining district of Thionville in Lorraine the immigrants form

1 Op. cit., p. Ir 3.

2 For the effects of annexation, see Phillipson, Termination of IV ar and Treaties of Peace, where several chapters are devoted to the subject.

${ }^{3}$ Cf. Jean Longuet (a French deputy), in The Nation, January 5, 19x8; p. 456.

Op. cit., p. 293. 
60 per cent. of the total number. The reannexation of Alsace-Lorraine to France would undoubtedly mean the expulsion or withdrawal of this immigrant population; so that serious economic disturbances would thereby be brought about. Furthermore, an enormous amount of German capital has come into the territory, especially for the purpose of developing the mining and metallurgical industries ${ }^{1}$; whether it remained in the country or were expropriated it would constitute a disturbing factor in the existing economic system.

The business circles in the towns of Alsace-Lorraine, as in the towns of Germany in general, are always The com- opposed to radical changes. It has already

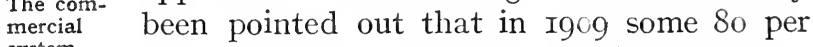
system. cent. of the exports of the provinces went to Germany, and 80 per cent. of their imports came from Germany; and that even in regard to the remaining 20 per cent. Belgium-and not France-took the first place. Thus, if Alsace-Lorraine left the German Zollverein its commerce would suffer a great loss. The commercial organisation and methods are essentially German. Indeed, from the point of view of economic conditions, Alsace-Lorraine is very closely, if not inseparably, bound up with Germany.

Till I895 the French fiscal legislation was in force; after that date a complete change was effected. The Fiscal most vigorous opponents of German rule legislation. cannot but admit the great improvements made in the modes and incidence of taxation, as well as in the whole range of industrial and commercial legislation, and recognise that all these reforms have become part and parcel of the life and activities of the people. "Toutes ces réformes," says M. Wetterlé, " dont l'opportunité et la justice étaient reconnues par

1 See the next chapter on the Franco German coal and iron problem. 
une population intelligente et réfléchie, étaient entrées profondément dans nos mœurs." 1

The religious question, again, is one of the greatest difficulty. We have already pointed out ${ }^{2}$ that the great majority of the population-indeed The religious about 80 per cent.-are Roman Catholics, question. that the régime of the French Concordat of I80 I still obtains in Alsace-Lorraine, and that the elementary schools have remained confessional; so that in this respect the attitude of the people, devoted as they are to their religion, is diametrically opposed to the French separationist régime and anti-clerical spirit. The great teaching and charitable Orders of the Roman Church are recognised by law. As the writer just referred to observes, there is an "antinomie totale entre les habitudes et coutumes de la France et celles de l' AlsaceLorraine." " The crisis of the "Kulturkampf" has long ago passed away, so far as these provinces are concerned ; they remain attached as strongly as ever to the old traditions of worship and ecclesiastical organisation. The Protestant sections of the community, too, would be opposed to any changes tending to break up the collaboration between Church and State, or to interfere substantially with the prevailing conditions. Even the most vigorous opponents of Germany are agreed that an attempt to secularise education and to substitute a lay staff for the existing congréganistes would provoke the strongest resistance.

Apart from this religious difference in elementary education, there are striking discrepancies between the French and German systems of higher instruction. For example, in the case

The educational of the baccalaureat the curriculum and the standard

1 Op. cit., p. 294.

3 Op. cit., p. 297. Ct. Lichtenberger, op. cit., pp. II6 seq. 
vary to a very large extent ; and the courses, methods, and requirements of university studies in general differ materially. Moreover, various German qualifications and diplomas, having no equivalent in France, have already been acquired by students and continue to be awarded at the University of Strassburg. Thus, M. Wetterlé points out that, in case of reannexation, it would be found difficult to regulate the legal status of doctors, solicitors, notaries, chemists, philologues, referendaries, and assessors, who possess German degrees. Furthermore, in regard to education in general, due account must be taken of the fact that Alsace is " un pays de culture mixte," " and that its very foundations are more Germanic than Gallic.

In addition to all these difficulties, one must mention that created by the position of the immigrants and Immigrants the younger generation, who constitute a and younger considerable proportion of the population. ${ }^{2}$ generation. More than I2 per cent. of the marriages year by year are " mixed" ; and nearly 30 per cent. of the children born are either entirely German or the issue of these mixed marriages. If the provinces were wrested back from Germany, no satisfactory adjustment of the position of these immigrants and their families could be effected ; indeed, there would inevitably be a repetition of the emigration and expulsions of $187 \mathrm{I}$, and consequent perpetuation of grievances, resentment, and hatred rendering impossible an amicable accommodation between France and Germany.

Again and this is a matter of the greatest consequence - the nationalist movement in Alsace-Lorraine, as we have shown fully in a previous chapter, ${ }^{3}$ has taken

1 Lichtenberger, op. cit., p. II4.

2 Cf. the official statistics given in Dic Bevölkerung Elsass-Lothringens (Strassburg, 1908).

${ }^{3}$ See chap. $x$. 
such a powerful hold of the people that it will certainly be impossible to eliminate it by the union of the provinces to France with her centralised government and administration. The people $\begin{gathered}\text { The previous } \\ \text { nationalist }\end{gathered}$ have firmly and definitely pledged themselves movement. to autonomy; for nearly thirty years their strivings and aspirations have unswervingly aimed at that object; it is difficult to see how such object could be realised if the territory were incorporated within the framework of France; whereas it is capable of full and complete realisation within the framework of the German Empire. Another solution consonant to the autonomist movement would be the establishment of entire political independence; but this solution likewise means no reannexation to France.

As to other kinds of difficulties and differences, M. Wetterlé himself admits that " la liste pourrait en être considérablement allongée." ' For example, there would be the expulsion of public difficulties. officials, or the special regulation of their position; many of these are recognised by the Alsatians and Lorrainers as possessing conspicuous ability." And there would be a great variety of further questions and claims, the adjustment of which would undoubtedly create difficulties through the clash of conflicting interests. ${ }^{3}$

In consequence of all these difficulties incidental to reannexation, it has been suggested that, after the return of the provinces to France a sort of Interregnum interregnum, or transition stage, with pro- suggested. visional legislation, should be allowed in them for a specified or indefinite period, in order that the more

1 Op. cit., p. 298.

2 Cf. Lichtenberger, op. cit., p. Ioo.

3 For many other kinds of questions that would have to be solved, see Phillipson, Termination of $W$ ar and Treaties of Peace, pp. 290 seq. 
striking differences introduced by the German régime might be smoothed over, the acquired rights and interests safeguarded as much as possible, and the assimilation to France facilitated. But this suggestion, like the entire proposal of reannexation, fails to take into account two most vital considerations: first, the autonomist movement established and developed during a whole generation, and, secondly, whether the population are in favour of reunion with France (i.e. the question of a plebiscite). To disregard these important considerations is to revert to the old arbitrary proceedings, which are to-day condemned by all the civilised peoples of the world as being contrary to the essential and inalienable right of national self-determination.

Accordingly, a plebiscite must be the condition precedent to the adoption of any course that can be regarded as a satisfactory solution in the case of a people like the Alsace-Lorrainers who possess a national consciousness and a national individuality. This question of a plebiscite, the reasons for resorting to it, its use in previous cases of annexation, and the difficulties involved in it will be dealt with in our final chapter ; in the meantime we have to consider certain other proposals that have been advanced for solving the Alsace-Lorraine problem, e.g. the establishment of Alsace-Lorraine as an autonomous State within the German Empire, the establishment of the provinces as an independent neutralised State, and the partition of the disputed territory or other readjustment of the existing frontiers. But before considering these proposals we must deal very briefly with the Franco-German coal and iron problem in reference to retrocession. 


\section{CHAPTER XIII}

\section{REANNEXATION AND THE FRANCO-GERMAN COAL AND IRON PROBLEM}

Commercial basis of the war-German declaration in I9I5 as to economic needs-Coal and iron in modern war-German need of coal and iron - German demands as to Briey and Longwy-Coal resources of France and Germany-Iron ore in Lorraine-Iron resources of GermanyEffect of depriving Germany of the Lorraine ore.

IN this chapter, following on the consideration of the various difficulties incidental to the proposed retrocession of Alsace-Lorraine to France, we may conveniently turn our attention to the special FrancoGerman coal and iron problem, which has frequently been raised during the last two or three years. The essential question here is whether retrocession would bring about a satisfactory solution of this problem.

The present war is to a very large extent commercial in its origin, in its means, and in its objects. In regard to its origin, it has been pointed out ${ }^{1}$ that the intensive and continuous over-production in Germany was preparing the way for an

Commercial basis of the war. industrial cataclysm, if she failed to increase the number and importance of her outlets, in view of the fact that her principal customers were beginning to consider it necessary to protect themselves against her pacific penetration; another such revolution might bring with it an internal crisis, because the rise

1 Cf. M. Alfassa, Le fer et le charbon lorrains (Paris, 19I6). (Preface by A. Lebon, a former French minister.) 
in the cost of necessaries was far greater proportionately than the rise in wages. In the conduct of the war the commercial aspect is obvious - it is a war of machines and shells; the nations are specially organised to promote and accelerate the output of the essential industrial products, the practice of blockades is established by the belligerents for the very purpose of interfering with their enemies' commercial and industrial activity. Thus the object of the war, too, has a commercial basis, seen on the one hand in the resolution of the Allied Conference held in Paris, June I7, I9I6, to the effect that the Allies should ensure their commercial independence with regard to the Central Empires, and, on the other hand, in the declarations contained in the confidential memorandum presented to the German Imperial Chancellor, May 30, I9I5, by the six leading industrial and agricultural associations of Germany.

The Germans, believing at the latter date that they were about to secure a military triumph over their German adversaries, declared in the following manner declaration some of their economic aims, and particularly in 1915 , as
to economic their intentions as to the necessary acquisineeds. $\quad$ tions of new coal and iron districts: "Nothing but the economic and military weakening of our adversaries will obtain for us the peace we desire-as a commencement Belgium, which lies so near our industrial centre, must in the monetary, financial, and postal sense become subject to the laws of the Empire. Her railways and waterways must be closely connected with our own communications. As regards France, it is of vital importance, both from the point of view of our relations with England, and from that of our maritime future, that we should possess the coast region to as far as the Somme. The 'Hinterland' should be of an extent sufficient to ensure their 


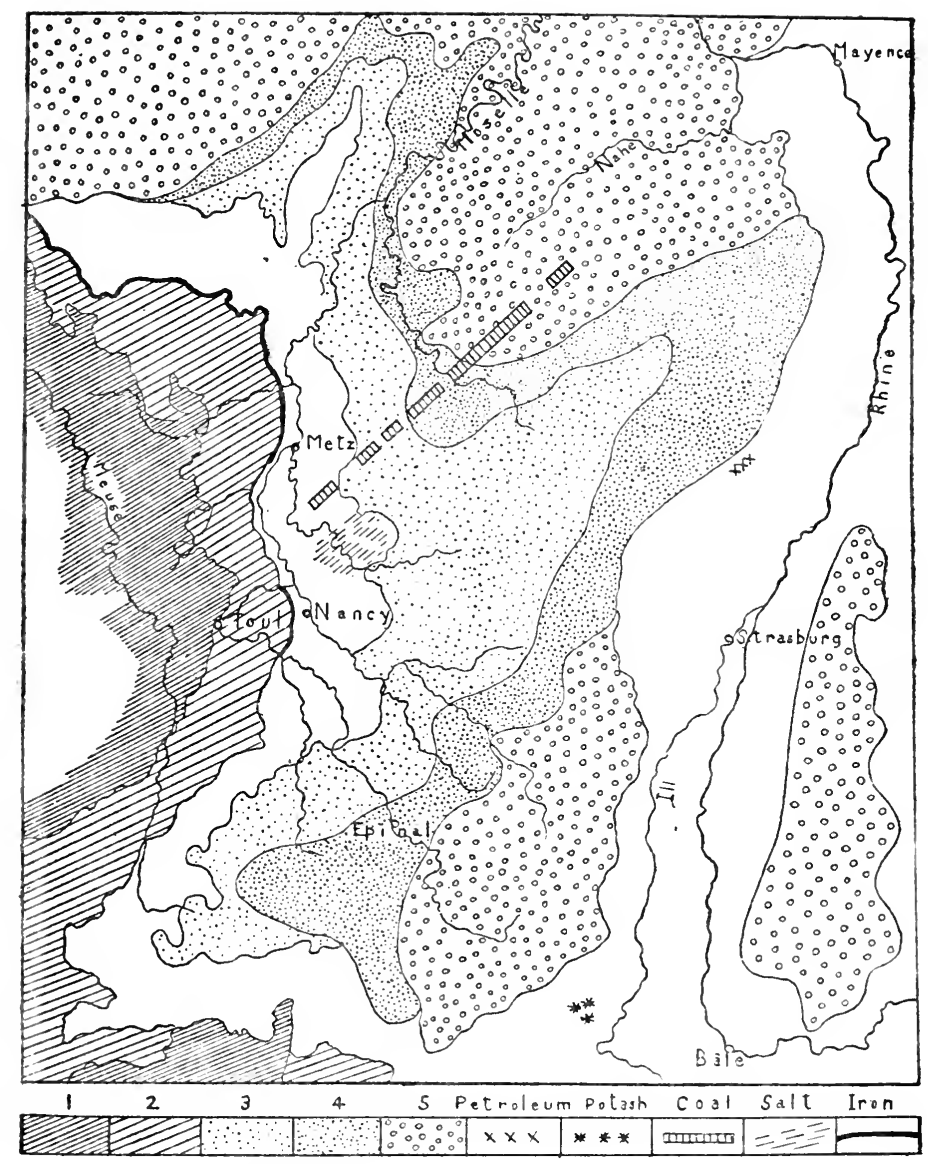

Geological Sketch-map of Alsace-Lorraine.

I. Upper'Jurassic clays and limestones. 2. Middle Jurassic clays and limestones with the ironcontaining beds at their base, shown by the black line. 3. Triassic marls and limestones. Between these and the Middle Jurassic limestones lies the Lias clay, left white on the map. 4 Triassic grits. 5. Ancient sedimentary or crystalline rocks of the Vosges, Black Forest and Rhine Highlands. The Rhine Rift Valley is chiefly floored by recent deposits, and is left blank on the map, but patches of Triassic and Jurassic rocks occur at its margins. Scale about $\mathrm{I}: 2,000,000$. (In part after Barre.) 

full importance to the ports forming the outlets for the canals behind them. In addition, it is self-evident that the fortresses of Verdun and Belfort, and the forts west of the Vosges lying between them, could not be left in French hands. By the acquisition of the line of the Meuse and of the French coast the iron-producing district of Briey, as well as the coalfields of the North and the Pas de Calais, would be acquired." 1

The importance of coal and iron for carrying on a modern war is emphasised: "Territorial annexations, coal and such as those of the mineral and coal regions, iron in would not merely extend our industrial power. modern war. They represent military necessities, as is proved by the following consideration. The monthly production of pig-iron in Germany has risen since August I9 I4 to about a million tons-in other words, it has all but doubled. The production of steel exceeds one million tons per month. It must be added that neither pig-iron nor steel is abundant; but if this is true of Germany it is still more true of neutral countries. The manufacture of shells requires a quality of iron and steel such as would not formerly have been believed. For cast-iron shells alone, which are an inferior substitute for those in steel, an average production of 4,000 tons of iron per day has been necessary. ${ }^{2}$ If our production of pig-iron and steel had not been doubled, the war could not have been continued. As the material for the manufacture of these quantities of pig-iron and steel, the minette of Lorraine becomes more and more important, for this mineral is the only one that we can produce in rapidly increasing quantities. At this moment minette represents from 60

Translation as given in Fortnightly Review, November 1917.

2 In I9I6 the output increased enormously; the monthly average of pigiron was $1,150,000$ tons; and that of steel was (towards the end of the year) between $1,400,000$ and $1,500,000$ tons. 
to 8 o per cent. of our manufacture of pig-iron and steel. If the production of minette were imperilled the war would be as good as lost. Nor should it be forgotten that the large production of steel from minette provides the only source, when the import of phosphates is blocked, from which German agriculture can obtain the phosphoric acid that it requires." '

It is therefore urged that the acquisition by Germany of further coal and iron resources is imperative: "The security of the German Empire in a future German
need of war imperiously requires the possession of all more coal the mines of minette, including the fortresses of Longwy and Verdun. The possession of the large quantity of coal, and especially of coal rich in bitumen, which abounds in the northern basin of France, is at least as important as that of iron ore for the decision of a war. Belgium and Northern France produce together over forty million tons a year. It appears to be true that the systematic production of coal from the Belgian mines has had during the present war the greatest influence in inducing several of our neighbours to preserve their neutrality. Coal, then, is one of the most decisive means of political influence in the world. Industrial neutral States are obliged to obey the belligerent which can best assure their needed quantity of coal. This we are unable to do of our own resources, and it is to Belgian coal that we are looking to prevent our neutral neighbours from being completely dependent on England." ?

Professor Hermann Schumacher of Bonn, one of the signatories of the annexationist manifesto, holds that it is essential to modify the Franco-German frontier in such a way as to assure for Germany adequate supplies of coal and iron and deprive the enemy of 
them. "Without the Lorraine ore," he says, "we should not be able to supply iron and steel necessary for the war. The Treaty of Frankfort gave us all Lorraine. A mistake was committed, for the geologists consulted by Bismarck were mistaken. It is known since I880 that, as against the previsions of Bismarck, the Briey basin, which continues that of Longwy, is one of the richest parts of France. To-day we can correct this mistake, since we have occupied from the beginning of the war and we hold firmly in our hands the second raw material of war industry-coal. Just as we could not prosecute the war if we had not the rich Lorraine soil, so we could not prosecute it victoriously if we had not the rich coal-fields of Belgium and Northern France. As we know to-day what signify munitions in a war, we must tell ourselves that it is necessary for the life of our people, for peace and for war, to possess these sources of war and commercial power." 1

Similarly, in the Prussian Diet, February 2I, 22, I9I7, in the course of a debate on the importance of completing the economic frontier by the inclusion of Briey and Longwy, it was said German that Germany could not allow the French to to Briey and be in possession of these districts, that it would be fatal for her in the next war, when she would be again blockaded, and must obtain the steel for her guns. Nor could she count on promptly occupying the industrial districts of France and Belgium on the declaration of war, as she had done on this occasion, for experience would teach the English and the French to take preventive measures. Therefore it was a question of life and death for Germany. Prince Schönaich Carolath, the leader of the National Liberal

\footnotetext{
1 Le Temps, 28 août 1915.
} 
party, though an annexationist, did not support these extravagant demands, and some of the National Liberals, led by Professor Brandenburg, the president of the party in Saxony, declined to associate themselves with such an extremist policy. But Count Westarp, the leader of the Conservatives, repeated the demand for Briey and Longwy in the Reichstag, March 27, I9I7. The German Socialists were opposed to these views, and the masses of the German population paid little heed to these annexationist proposals.

However this may be, Germany has long been attracted towards iron-the symbol of and key to material force. As a recent French writer

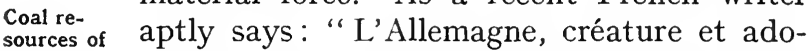
Germany ratrice de la force, ne pouvait pas ne pas and France. être attirée vers le fer, instrument et moyen de la force." ' She is aware that she has ample supplies of coal-it has been calculated that her resources would suffice for about a thousand years. Besides her rich Westphalian coalfields, she possesses the Sarre basin and other coal regions which she acquired by the Treaty of Paris, November I8I5, the Convention of Frankfort, I8I9, and the Treaty of Frankfort, I87 I. The Sarre basin lies on the right bank of the Moselle between this river and the Rhine, and it occupies a region about I0o kilometres long by between 30 and 35 kilometres wide- 45 kilometres being in Rhenish Prussia and the Bavarian Palatinate, 45 in AlsaceLorraine, and Io in Meurthe-et-Moselle. We may here recall that in July I8 I5 a memorandum was laid before the Prussian plenipotentiaries on their way to the Paris Peace Conference by one Herr Böcking, commissioner of the Sarre mines. He explained that

1 F. Engerand, Les Frontières lorraines et la force allemande (Paris, 1916), préface, p. i. 
the cession of the Sarre coalfield to Prussia would compel France to import her steel from the latter country and lower her import duties, to the advantage of German industries. Such turned out actually to be the result ; and the French industries of the Moselle region declined accordingly. Indeed, had it not been for the importation of coal from Great Britain, France would have found herself in a disastrous condition.

It is thought in some quarters in France that if Germany retroceded Alsace-Lorraine to France and remained in possession of the Sarre coalfields, Iron ore of Germany would continue to enjoy industrial Lorraine. predominance; and therefore it is urged that France should also regain the Sarre basin, because of the proximity of this coalfield to the Lorraine ironfields, and the great distance of the British coalfields from the latter. Such a solution is obviously as inexpedient as it is impossible, for it would reduce Germany to a condition of economic ruin-and such intention has been repeatedly disclaimed on the part of the Allies.

Even in the case of the mere retrocession of the territories annexed in $I 87 \mathrm{I}$ the iron resources of Germany would be so diminished that she would not have enough within her own country not only for military purposes, but for commerce and peaceable manufactures. In addition to the German pronouncements given above we may refer to the statement of Herr Hermann Wendel, the German majority Socialist deputy, to the effect that to take away the iron of Lorraine from Germany would be " to force the German metal industry to its knees" ; and Herr Hue, of the German Miners' Federation, observed in the Prussian Diet that it would also mean " the ruin of the German coal industry." To obviate such contingencies it has been suggested by certain French writers and 
publicists that, as Germany without Alsace-Lorraine would still have more coal than France, she would be able to exchange her surplus for French iron. It is thought, too, that in such a case it will be necessary to establish " the economic exterritoriality of the Thionville district," i.e. owing to the inadequacy of the French coal supplies and the fear of overproduction, the factories of annexed Lorraine will have to be excluded from the French market. ${ }^{1}$ Others point out that it is only by depriving Germany of her iron ore that the military menace on the Continent will be removed. "Laisser la sidérurgie allemande florissante," says M. de Launay: "c'est lui permettre, après la guerre, de reconquérir aussitôt le marché mondial en écrasant la concurrence débile de nos usines ruinées et pillées, de nos flottes fatiguées et amoindries; c'est lui fournir le moyen de préparer une prompte revanche." :

In I9Io, at the International Geological Congress at Stockholm, in the course of an investigation into the world's iron resources, it was calculated that Iron reGerman Lorraine contained I,830 million sources of German Lorraine contained I, 830 million
Germany. tonnes, to which those responsible for the report tacitly added 270 million tonnes of Luxemburg as forming part of the Zollverein, that the rest of Germany had only 700 million tonnes, whilst the amount of the ore of French Lorraine was estimated at 3,000 million tonnes. ${ }^{3}$ Now, looking at the rate of consumption, we find that in the last normal year, I9I3, Germany used up 42 to 43 million tonnes, comprising $2 \mathrm{I}$ million tonnes obtained from annexed Lorraine, 7 million tonnes from the rest of Germany,

1 Alfassa, op. cit., p. $3^{6}$.

$2 \mathrm{~L}$. de Launay, Le probleme franco-allemand du fer, in Revue des Deux Mondes, July 15, 1916, p. 345.

3 Ibid., p. 335 . 
and the remainder imported from abroad (e.g. Sweden and Spain). ${ }^{1}$ That is, the pre-war total resources of Germany, viz. 2,800 million tonnes, would last only about sixty-five years, assuming that there would be no annual increase in the consumption. In point of fact, since August IgI4 Germany's production of pigiron and steel has doubled in amount; otherwise she would have found it impossible to continue the war. Had her Lorraine supplies been seriously interfered with, the war would by now certainly have been ended. Hence-among other reasons-her determination not to abandon any portion of the annexed provinces, and if possible to add thereto other neighbouring territory rich in minerals.

The great metallurgical development of Lorraine, like the progress in the Alsatian industries, is due to German brains, energy, and capital ; and any solution that deprived Germany of the $\begin{array}{r}\text { depriving } \\ \text { Germany of }\end{array}$ minette would not be to the economic advant- the Lorraine age of Europe generally, and would inflict ore. on a great industrial nation an unparalleled economic disaster, whilst the interests of peace would not thereby be advanced. Indeed, the future peace of Europe would be more than ever jeopardised ; for it is nothing more than absurd to imagine that the potential labour, the industrial instincts, the business organisation, the commercial impulse, the economic progress of one of the greatest nations of the world could be suppressed by doubtful military victories, by factitious combinations of States, or by an unnatural policy of exclusion. The iron-mines of Lorraine work in close association with the coalfields of the Rhine basin; and the Prussian State Railways make reduced charges to the Lorraine manufacturers as a compensation for their inland 
position; so that to put an end to such desirable cooperation would entail great loss. The solution of the Franco-German coal and iron problem can be effected by establishing a régime of free trade if AlsaceLorraine remains within the German Empire (say, as an autonomous State), or by setting up the provinces as an independent State ; but it is very doubtful indeed whether a satisfactory solution can be reached by retroceding the territory to France, unless the economic organisation and system of commercial relationships of Western Europe be altered in such a way as to ensure a supply of coal and iron equally and impartially to those who are in need thereof. 


\section{CHAPTER XIV}

\section{SOLUTIONS SUGGESTED: (b) AUTONOMY WITHIN THE GERMAN EMPIRE}

The nationalist ideal-Alsace-Lorraine can no longer remain a Reichsland - German view in I 898 - Swiss view-French views--Recent German opinion-German Socialist view, I9I7-Form of autonomous government-Position of Alsace-Lorraine as an autonomous State-Autonomy followed by plebiscite suggested.

As we have already fully described the autonomist movement, there is no need to do more here than add a few observations by way of supplement.

The establishment of Alsace-Lorraine as an autonomous State within the framework of the German Empire would be the fulfilment of the nationalist object, which has been aimed at by the nationatist great mass of Alsatians and Lorrainers for ideal. some thirty years. This would make of the provinces - which have hitherto constituted only a Reichsland, that is, common imperial territory, as the sinister symbol of conquest-a new federal unit, empowered to draw up its own constitution (subject, like every other German State, to certain limitations imposed by the imperial constitution), to choose its own government and administration, which would be directly responsible to the people, and to a very great extent make its own law.

In a previous chapter ${ }^{1}$ the demands of authoritative Alsace-Lorraine leaders have been set forth; and we

1 See chap. $x$. 
have seen that they have repeatedly claimed autonomy within the Empire and have asserted that that was Alsace- all they and the people wanted. Had the GerLorraine can mans possessed clearer foresight and greater no longer
remain a political wisdom they would, even in their Reichsland. own true interests, have paid regard to the wishes thus expressed and to the increasing nationalist movement, and would have set up the régime and political structure required. Such an amicable accommodation may well have facilitated the rapprochement between France and Germany, and so may have done much to promote the public peace of Europe. However this may be, it is clear that Alsace-Lorraine can no longer remain a Reichsland after the conclusion of this war ; and when a solution is sought the consistent and reiterated demands for autonomy cannot be eliminated.

The Alsatians and Lorrainers were not alone in demanding autonomy for their provinces. They were German supported by writers and publicists in various view in 1898 . countries. Only one or two need be mentioned here as representative. Thus, Moritz von Egidy, an officer of the Prussian Army, delivered a number of lectures in several German towns, SeptemberDecember, 1898 , on the Tsar's peace'manifesto, in the course $o$ which he urged that the Reichsland question should and could be solved by applying the principle 'Alsace-Lorraine for the Alsace-Lorrainers,' and conformably thereto granting an autonomous government to the people.

MM. Lichtenberger, who maintain that AlsaceSwiss Lorraine would have been satisfied with view. autonomy within the German Empire, refer ${ }^{1}$ to the view expressed by a Swiss impartial observer, 
M. Albert Bonnard. In an article in the Bibliothèque Universelle of Lausanne, the latter said that a particularist (or nationalist) Alsace, having acquired her liberty, would be proud and jealous of her status and would be contented with it, as she would be enabled to proceed in her own way and develop her own individuality.

As to France, we have already shown that before the recent revanche recrudescence consequent on the outbreak of the war she would have willingly French accepted the autonomist solution for Alsace- views. Lorraine, on the ground that the overwhelming majority of Alsatians and Lorrainers had made it their definitive goal. The following words have been quoted on a previous page, but they may be recalled here on account of their special appropriateness: " Pour notre modeste part, nous croyons que, si l'Alsace-Lorraine était satisfaite de cette autonomie restreinte, nous aurions mauvaise grâce à être plus royalistes que le roi. . . . Cette solution, nous l'accepterions donc de grand cœur." "1

This view has also found supporters recently among leading German thinkers. Thus, Professor Wilhelm Förster, the astronomer of Berlin, whilst justifying the annexation of the provinces on the ground of frontier security, said in I9I3, that in his opinion the difficulties of Germany with regard to France and Alsace-Lorraine could be removed by giving the latter as large a measure of independence as is possible within the German confederation. "Since France in I866," he observes, " demanded the whole left bank of the Rhine, and in I870 attacked Germany by force of arms, it became

1 Général Palat, L'Alliance franco-allemande ou la guerre (Paris, 1914), pp. $\mathrm{I}_{45}, \mathrm{I}_{4} 6$. 
clear that Germany must, for her own security, extend her borders across the Rhine and not leave the powerful fortress of Metz on her frontier any longer in French hands. But Germany has throughout treated the people of Elsass-Lothringen in embittering fashion. By this means the painful influence of the conquest over the feelings of the French people has been kept alive and constantly renewed. In spite of this, a vote by the people of Alsace-Lorraine would now (Sept. I9I3) probably show a majority in favour of remaining part of Germany. This would mainly be on economic grounds, as the fruit and wine industry of ElsassLothringen is in closer relations to the interests of Germany than to those of France. How can the relations between Germany and France be made better? Certainly through giving the people of ElsassLothringen the greatest possible independence, with freedom to continue to use the French language and the like. To this end, there must rule between Germany and France, and for that matter through Europe generally, a higher socio-political relation than at present. This should begin with a customs-union and with parliamentary control. The International Court needs organisation and expansion in power until its jurisdiction includes the whole earth." ${ }_{1}$

Similarly, Professor Rudolf Eucken of Jena observed in September I9I3: "Elsass-Lothringen is for us Germans no longer a question. The land, the seat of an old German race, is a piece of Germany; in its language and its customs, German. We Germans are sensitive to all discussion of this question by foreign people as a revival of the French restlessness towards this problem. Inside of Germany I wish to see granted to Elsass-Lothringen all possible inde-

1 Quoted by Jordan, op. cit., pp. 26, 27. 
pendence; but this is a problem for ever and wholly German." 1

Further, quite recently the opinion in favour of autonomy within the Empire has been gaining ground in Germany. ${ }^{2}$ At the German Socialist Conference at Würzburg, October I4-I7, I9I7, Herr Scheidemann declared: "We demand view, 1917. complete autonomy for Alsace-Lorraine, but also demand that Alsace-Lorraine shall remain part of the German Empire." :

In the event of adopting this autonomist solution, it has been suggested that a difficulty would arise in regard to the kind of government to be introduced into the newly constituted State, $i$. Form of duced into the newly constituted State, i.e. autonomous
whether republican or monarchical. Some government. writers think that it could not be republican, or even monarchical (failing the necessary traditions). But the determining factor in this respect is, or should be, the will of the people. In Alsace-Lorraine, however, public opinion has not been unanimous on the point. Probably the clerical group, representing the Catholic and the Lutheran sections of the population, would prefer a monarchical form of government, for example, like that of the Grand Duchy of Baden; whilst the Alsatian Radicals, Socialists, and other nationalists would be in favour of a republic, and regard the free cities of Hamburg, Bremen, and Lübeck as analogous precedents. Indeed, for great numbers of Alsatians the very word "autonomy" implies a republican organisation within the framework of the German Empire.

If Alsace-Lorraine becomes an autonomous State-

1 Quoted by Jordan, op. cit., pp. 27, 28.

2 Cf. Deutsche Revue, June I917, referred to by Dr. Dillon, Fortnightly Review, September 1917, p. 345, note.

${ }_{3}$ Daily Telegraph, October 17, 1917. 
either republican or monarchical-what will be its position within the confederation? The latter now Position of comprises four kingdoms, six grand duchies, Alsace- five duchies, seven principalities, three free an autono- towns, and the Reichsland. Sovereignty is mous state. vested in the imperial government. ${ }^{1}$ The Bundesrat (Federal Council), which represents the totality of the co-ordinated German States, is the embodiment of that sovereignty. The powers of government are divided between the imperial authorities and those of the State. In the case of the former they are specifically limited; in the case of the latter they are unlimited and residual. The legislative power of the Empire takes precedence in regard to such matters as the rights of citizenship, the army and navy, currency, weights and measures, tariffs, patents, copyright, fluvial and canal navigation, etc. On the other hand, a very wide domain is reserved to the States themselves, e.g. the determination of their own forms of government and the laws of succession, the relations between Church and State, all questions relating to their internal administration, the framing of their budgets, the control of public instruction, the making of laws as to land tenure and highways, the adoption of police regulations, etc. Justice is administered in the name of the particular State concerned and not in that of the Empire; and the judiciary is appointed by the State. The execution of imperial measures, except within the restricted spheres, devolves upon the officials of the respective States.

Thus, if Alsace-Lorraine were made an autonomous State it would enjoy a large measure of legislative and administrative independence, it would be able to develop to a very great extent its own personality, and

1 Cf. F. A. Ogg, The Governments of Europe (New York, 1913), pp. 205 seq. 
would at the same time possess the various advantages of membership of a great Empire. Its traditions as well as its interests could be safeguarded; and, being of a mixed Franco-German culture, it would serve as a bond of union between the two neighbouring peoples who have so long been at loggerheads. Sometimes a fear has been expressed that the newly established government might not work harmoniously with the Imperial Government ; but there is no ground for such apprehension, and no plausible consideration has been advanced in support thereof. The Reichsland is no longer regarded as a guarantee or pledge of German unity; and to set it up as an autonomous State is not necessarily to impair German security.

We have more than once put forth the contention, and submitted evidence for it, that before the present war Alsace-Lorraine would have been fully satisfied with autonomy. Now it may be Autonomy thought that, in consequence of the war plebiscite. various complications have supervened, rendering that conclusion less certain. In these circumstances a plan suggested by Novicow in I9I3 may well be adopted as a feasible expedient, i.e. the establishment of autonomy, to be followed ten or fifteen years later by a plebiscite. ${ }^{1}$ He says that if the population vote then in favour of France, Alsace-Lorraine should be retroceded; but the referendum in Lorraine must be distinct from that in Alsace, and the decision of one province is not to be binding on the other. If the date of the plebiscite is fixed ten or fifteen years in advance, the population will remain conscious of a period of transition and hence they will adapt and prepare themselves accordingly. This arrangement, of course, assumes that no undue influence will in the 
meantime be exercised by the German authorities. How to ensure the prevention of such pressure is the main difficulty. In the first place, such pressure would be minimised or promptly revealed in the case of a completely autonomous State; secondly, the Imperial Government might give an earnest of its good faith by permitting a neutral commission to remain in the territory for the purpose of exercising a certain surveillance until the referendum has been completed. ${ }^{1}$

1 See further the final chapter as to the question of plebiscite generally. 


\section{CHAPTER XV}

SOLUTIONS SUGGESTED: (c) ALSACE-LORRAINE AS AN INDEPENDENT STATE

Proposed neutralisation-Suggested in $1870-$ German objections-Population to be consulted-Resolution of League of Peace, 1884-Form of independent government-Various matters for adjustment-Advantages of creating an independent Alsace-Lorraine: Meeting the wishes of the people-Revanche obviated-Fusion of Germanic and Gallic elements - Military service difficulties removed-Bond of union between France and Germany-Would be a "buffer" State. Future international co-operation and treaties.

IT has frequently been proposed of late that the AlsaceLorraine problem should be solved by erecting the provinces into an independent State. Such a plan would manifestly necessitate the neutralisaneutralisation of the new State under the tion. guarantee of the society of States or league of nations, whose establishment is an indispensable condition for securing the future peace of the world. It may be said, with the example of Belgium before us, that little confidence can be placed in the plan of neutralisation. But the flagrant violation of a law or engagement will not induce law-abiding and honourable citizens and nations to forswear all law and engagements, and to consent to abandon themselves to a condition of chaos and lawlessness. Ubi societas ibi ius. Where there is human life, where there are groupings of human individuals-be it clans, tribes, nations, States-there must inevitably be some governing law. The fact that the neutrality of Belgium was unconscionably dis- 
regarded in I9I4 by a powerful State is no argument that the neutralisation of small States is useless. The best answer is to continue to neutralise small States - especially so those situated between greater Statesand reinforce the underlying international engagement by more potent sanctions than have hitherto been available-and the must powerful safeguard is the formation of a " partnership of nations " together with the creation of an international court, empowered to take cognisance of international claims and differences and to enforce its judgments by means of an international army or police, by the imposition of economic restrictions, and similar measures that will influence a refractory State. But this régime implies a general pacification, a considerable disarmament, and an alliance of the nations on the basis of amicable cooperation and mutual good, and not for the purpose of bolstering up a precarious equilibrium. The main thing is to assure a whole-hearted acceptance of the fundamental principle; the details necessary for its application can then be easily elaborated by negotiation. The present upheaval of the world, with its unparalleled slaughter and devastation, will surely serve as a drastic katharsis, a purgation for men and States, and will be a perpetual and convincing proof to all of the folly - indeed of the suicidal policy - of aggressions, of interfering with weaker neighbours, and of infringing the rules of established law and the dictates of public morality.

This proposal to neutralise Alsace-Lorraine is not new. It was brought forward as far back as I 870 by Suggested Count Agénor de Gasparin, that zealous in 1870. advocate of religious liberty. The view was afterwards adopted by various writers and publicists. Une of the most enthusiastic supporters was M. Tachard, 
who was French by birth, Alsatian by adoption, and German by education. During the régime of Gambetta he was the French ambassador in Belgium, and in that capacity advocated his proposal at many of the European Courts. He was so attached to the idea and so firmly convinced of the salutary effect of setting up another buffer State between France and Germany, that he declared that his sole desire was to have the word tampon (buffer) inscribed on his tombstone.

We have already referred to Bismarck's speech in the Reichstag, May 2, I87I, when he discussed the policy of annexation and various expedients German suggested as substitutes for it. Amongst objections. these was the neutralisation of the conquered provinces ; but he rejected this plan on the ground that the people would not be in a position to safeguard and defend their neutrality, and that, in the event of a renewed conflict between France and Germany, their French sympathies and interests would lead them to take the side of the former. Similarly, Treitschke repudiated the proposal ; he pointed to the " disgusting spectacle" of the "Luxemburg nation," and maintained that the neutralisation of Alsace-Lorraine would be a certain means for enabling France to recover her lost territory ${ }^{1}$ Other German opponents recalled the territorial transformations of the Revolutionary and Napoleonic periods, and asked their countrymen to remember the conduct of France, who on one occasion set up an "Independent Rhenish Republic" on the left bank of the Rhine, and afterwards, when she felt stronger, simply annexed it, with its three million inhabitants. But what was difficult of achievement in $187 \mathrm{I}$ is much easier nowadays. During the last half-century the world has more than ever become convinced of the I8 
utility and necessity of small States, of the illegitimacy and unwisdom of conquests, and of the right of peoples to determine their own destiny.

Whatever course be adopted as a solution of the Alsace-Lorraine problem-reannexation to France, Population establishment of autonomy within the German to be con- Empire, or the creation of an independent sulted. neutralised State-the population of the provinces should first be consulted and given an opportunity to express their will either by means of a referendum or by a vote of their specially elected representatives. To do so would be to vindicate in a triumphant manner this principle of national self-determination, and to recognise in the form of a striking and exemplary precedent this fundamental principle of public right. It is realised, and now asserted everywhere, that people are no longer like chattels, liable to be made the object of transactions between other contending nations. No one is entitled to neutralise the provinces in spite of them and without their consent; their free consent is indispensable to render the act of neutralisation valid, legitimate, and binding. The solution that is sought is not to be merely a settlement of an industrial or economic difference as between France or Germany, nor is it to be simply an adjustment of conflicting claims to the possession of a certain amount of territory. The solution must be such as will satisfy justice, reason, the conscience and desire of a compact population, and the interests of France and Germany and Europe in general.

At the general assembly of the members of the International League of Peace and Liberty, held at Geneva September 7, I884 (at which, however, no German members appear to have been present), a resolution 
was passed affirming that the Alsace-Lorrainers possessed the inalienable right of choosing their own government, that the Franco-German hostility is due to the annexation of $187 \mathrm{I}$, that the consequent state of armed peace is detrimental to the two nations and to Europe generally,

Resolution of League of Peace, that the provinces during their subjection to Germany (I87I-I884) repeatedly claimed the right to dispose of themselves, that the security of Germany (the principal reason given by her for the annexation) will be attained by neutralising the annexed territory under the sanction and guarantee of the European Powers, and that all disputes arising out of such arrangement shall be submitted to a court of arbitration. The following is the text of the resolution, which is at present of great interest and significance :

"I. Considérant que le droit des Alsaciens et des Lorrains de s'appartenir à eux-mêmes et par conséquent de choisir ou de constituer librement le gouvernement qu'il leur convient de se donner, est indiscutable, inaliénable, et imprescriptible ;

“2. Considérant que la seule cause d'hostilité qui existe entre la République française et l'Empire allemand est la situation faite à l'Alsace et à la Lorraine par les articles I, 2 et 3 du traité signé à Francfort le Io mai I87 I entre l'Allemagne et la France ;

“ 3. Que l'état de paix armée, qui est la conséquence de cette situation, est également dommageable pour les deux nations et pour toute l'Europe;

"4. Que la seule raison donnée par l'Allemagne pour stipuler l'annexion était la nécessité d'assurer la sécurité ;

" 5. Que depuis treize ans que l'Alsace et la Lorraine sont passées sous la domination allemande la manifestation constante de leurs sentiments, la rigueur 
croissante des mesures administratives et politiques prises à leur égard, l'attitude gardée par les députés qu'elle envoie au Reichstag, leur persévérance à réélire ces députés démontrent que leur volonté de disposer librement d'elles-mêmes est aussi ferme qu'elle l'était au lendemain de l'annexion;

"6. Que la neutralisation des territoires annexés, quelle que soit d'ailleurs la juridiction politique sous laquelle se rangeraient leurs habitants, donneraient à l'Allemagne une sécurité plus grande et plus réelle que ne le peut faire une possession toujours précaire qu'elle ne maintient que par la force;

“ 7. Qu'il est de l'intérêt commun de la France, de l'Allemagne, de l'Alsace, de la Lorraine, de l'Europe que cette neutralisation soit sanctionnée et garantie par tous les peuples européens;

\section{Par ces motifs:}

" L'assemblée émet le vœu suivant:

" La France et l'Allemagne abrogeront d'un commun accord les articles I, 2, et 3 du traité conclu à Francfort le ro mai $187 \mathrm{I}$.

" Le peuple alsacien et le peuple lorrain seront mis en situation de choisir librement l'une des trois solutions suivantes :

“ I. Annexion définitive de l'Alsace et de la Lorraine à l'Allemagne.

“ 2. Retour de l'Alsace et de la Lorraine à la France.

“ 3. Constitution de l'Alsace et de la Lorraine en un ou deux états indépendants et autonomes.

"Quelle que soit la décision du peuple alsacien et du peuple lorrain, cette décision fera loi pour l'Allemagne 
et pour la France et dans tous les cas entraînera la neutralisation des territoires alsaciens et lorrains.

"Le traité à intervenir entre la France, l'Allemagne et les autres Puissances contiendra une clause en vertu de laquelle toutes le difficultés auxquelles pourrait donner lieu son exécution, seront soumises en dernier ressort à un tribunal arbitral." '1

Having regard to the tendencies, aptitudes, and traditions of the Alsace-Lorrainers, we may safely conclude that, if they voted in favour of the independence and neutralisation of their independent provinces, they would prefer a republican to government. a monarchical system of government. In that case the name of the newly constituted State might well be The Alsace-Lorraine Republic, which is much more appropriate than the designation, which has been suggested, of The Rhenish Republic. Under this solution of neutralisation, the fortresses of Strassburg and Metz would be dismantled, and no others would be permitted to be constructed. That is to say, the neutralisation would imply disarmament, as in the case of Luxemburg, and would not be like the neutralisation of Belgium and Switzerland, which are obliged to maintain standing armies. We have to bear in mind that the provinces in question are together less than the size of Yorkshire. The best way to safeguard this disarmament would be for France and Germany to disarm their respective frontier zones, to an extent agreed upon, adjacent to Alsace-Lorraine. Thus there would be between the two Powers a threefold disarmed sphere, which would minimise, if not

1 La neutralité de l'Alsace-Lorraine. Compte rendu de l'A ssemblée Générale des membres de la ligue internationale de la paix et de la liberté. Tenue à Geneve le 7 sept. 1884. (Bâle, 1884.) 
render impossible, the occurrence of those "incidents" that so often prepare the way for an open rupture.

The various matters of adjustment consequent on the creation of a new State out of a portion of another Various State could be provided for by international matters for convention; and if need be an international adjustment. commission might be appointed to supervise their execution. Thus the right of option of nationality would be stipulated, allowing such inhabitants as desired it to retain their allegiance to Germany or to transfer it to France instead of assuming the new allegiance on the establishment of the new State. Every precaution must be taken to safeguard the rights of the minority, and in suitable cases to offer adequate compensation for the loss or interference with vested rights and interests. A certain pecuniary compensation might be paid to the German Empire for such property as may be transferred with the territory, and for expenditure on public works, etc. In order to avoid economic dislocation the new State should be allowed, like Luxemburg, to remain within the Zollverein, and a Franco-German commercial alliance, including Alsace-Lorraine, would be one of the most satisfactory means of solving also the coal and iron problem. To establish the freedom of navigation of the Rhine - which is the direct route to the Sarre coalfields and the Lorraine ironfields - would be in the general interest, and would promote the commercial intercourse and pacific relationships generally between France, Germany, and Alsace-Lorraine, as well as other States, especially so when the RhineDanube canal becomes available for international navigation; and such freedom of navigation would be the better ensured by making Alsace-Lorraine an 
independent State. There are many other questions that would necessarily arise for settlement: for example, those relating to treaties affecting the newly established State; public law and administration, revenue laws, the official language of the State, religion, the position of officials, the armed forces, the courts of law, judicial proceedings pending, untried offenders; public property of the State, charitable foundations, the state archives, the private domain of the State, unpaid taxes, private property of the German Emperor or other German sovereigns or princes ; the contractual obligations of the new State and apportionment of debts, concessions, and contracts other than public debts; deposits, pensions, claims based on war losses ; private rights and private law. To facilitate the solution of all these questions regard may be paid to the various guiding precedents and established rules; it is beyond our scope here to consider these separately ; so that it must suffice to refer to a work already cited in which they are fully and systematically dealt with. ${ }^{1}$

That the establishment of Alsace-Lorraine as an independent State would be attended by many signal advantages is obvious. It is highly probable that the great majority of the population Advantages that the great including the immigrants who have become pendent definitely settled in the country, would now Alsacehail such a solution with delight." Before

Lorraine. the present war the desire of the generality was for autonomy within the German Empire; but, what with the complications brought by the war, the revision of opinions it has occasioned, the manifestation of the democratic spirit in many parts of the world, and the universal assertion of the principle of national self-

1 See Phillipson. Termination of War and Treaties of Peace, pp. 302-34.

2 Cf. La Nation (an independent weekly paper of Geneva), June I6, I9I7. 
determination, it may well be that the former desire for autonomy has become transformed into a desire for complete independence. If this be so, the first and greatest advantage of such a solution would be that it conformed to the wishes of the population, who would thus be enabled to give free play to their deep local patriotism.

France, too, would be satisfied with this arrangement, assuming - as we may safely do-that it comMeeting mended itself to the Alsace-Lorrainers; and wishes of the amour-propre of Germany would (or the people. should) be little hurt thereby. The creation of an independent Alsace-Lorraine would partake of the nature of a compromise; so that, in view of the inveterate conflicting claims of France and Germany, neither Power could be considered as the vanquished Revanche party or as the outstanding victor, and obviated. hence neither party would feel the sting of humiliation or the need for revanche; neither party would be in the position to regard force alone as triumphant or as productive of good. As Dr. Fried, the distinguished German pacifist, has recently observed: "If we had not lost every claim to be considered as reasonable beings... in consequence of our three years' fight for trenches and rubbish-heaps, we should seek a way out of this fatal dilemma by a compromise which should primarily consider the interests of the population of the provinces, without giving the unconditional possession of them to either party. That would be a solution which would entitle neither France nor Germany to pose as conqueror, and would offer to each of them the possibility of ceasing to incur unspeakable sacrifice for the sake of a phantom." 1

\footnotetext{
1 Neue Zürcher Zeitung (Swiss independent paper), June 24, I9I7.
} 
Again, the fusion of the two elements-Germanic and Gallic-could continue apace without any heartsearchings and without any apprehension of ultimate difficulties, e.g. in case of a renewed Franco-German difference. The French emigrants who left the territory could freely and Gallic elements. return along with their families and descendants, and would be permitted either to retain their French allegiance or to accept the new citizenship; on the other hand, the German immigrants could remain if they thought fit to do so, and would no longer be deemed to be usurpers and interlopers. It is to be remembered that, even before I87I, the culture of the provinces was neither purely French nor purely German, but " mixed."

Further, this solution would remove the great difficulties in regard to military service; before, the Alsatians and Lorrainers who were enrolled Military in the German armies and who had French service. sympathies or relations and friends in France, realised their particularly painful position in the event of the outbreak of hostilities between the two Powers. Such a condition of things encourages desertion and treason ; and a Government adopting such a policy as to make this possible sows the wind to reap the whirlwind.

Then, too, an independent Alsace-Lorraine-with its bilingual people and its Franco-German civilisation -would, much more than under any other Bond of solution, serve as a permanent and salutary union beconnecting-link between France and Germany, France and and through its instrumentality the great Germany. rival nations would find it easier to get rid of their inveterate differences, to reach a mutual understanding, and to inaugurate an epoch of true peace and amitya consummation that would prove an inestimable 
blessing to themselves, to Europe, and indeed to the whole civilised world ; for, unless it is brought about, a league of nations cannot be established. By virtue of its position as intermediary and bond of union it would exert a moderating influence on chauvinism on the one side and pangermanism on the other; and through its traditions of freedom and newly acquired liberty it might well serve as a stimulus to the liberal movement in Germany, and a warning to would-be retrogressive reactionaries in France. Indeed, the country of Alsace-Lorraine, which has been a perennial cockpit of Europe, might appropriately offer its ancient city of Strassburg as the administrative seat of the League of Nations.

We have already mentioned the question of the free navigation of the Rhine, and the coal and iron problem which has aroused so much apprehension in Germany and such strong claims in France: the creation of an independent Alsace-Lorraine would make easy the settlement of both these difficulties. The new State, amicably disposed towards both Powers, and having intercourse with both, would need the markets of both, would welcome the capital of both, and would freely export coal and iron to both.

Finally, a neutralised Alsace-Lorraine would constitute a "buffer" State, and together with Belgium Would be and Luxemburg would form a great neutral a "buffer" belt between France and Germany. The

two Powers, no longer remaining in contact, would find it easier to disarm; and both would thus be in a position to accept more readily the principle of general disarmament if introduced into the scheme of a League of Nations. We may here recall that in I867 war would probably have broken out between France and Prussia in respect of the possession of the 
fortress of Luxemburg, had not Lord Stanley interposed to suggest the neutralisation of the duchy ; and if Alsace-Lorraine had been a neutralised independent State in 1870 it is possible that the Franco-German War might have been prevented. (The neutrality of Belgium in I9I4 was not on the same footing as AlsaceLorraine would have occupied in 1870 , had it then been a neutral country.) Despite the example of Belgium in I9I4, the value of buffer States has been and will continue to be everywhere recognised. Persia has been an effective buffer between British and Russian interests, Afghanistan between Russia and India, and Tibet between India and Chinese Turkestan-although, it is true, these countries are in a different position geographically and economically from that of such territories as Belgium and Alsace-Lorraine. But Switzerland is also an independent and neutralised buffer State, and her neutrality has been respected in the present war. Those who object to the neutralisation of Alsace-Lorraine say, however, that the neutrality of Switzerland was not violated by the Germans simply because she possesses an efficient army, which she promptly mobilised for self-defence in case of attempted invasion ; whereas Alsace-Lorraine, being so small a territory and possessing so small a population, could not be expected to maintain an army that would be similarly effective.

This view is certainly tenable if we take it for granted that after the present war a neutralised and independent Alsace-Lorraine would be protected by no more than a "scrap of paper," and Future inwould be left isolated by Europe in the event co-operation of an attempted invasion on the part, say, of the Germans or the French. On the contrary, the neutralisation scheme necessarily implies that after 
the war the civilised peoples of the world will effect a closer association-be it called league, society, or partnership of nations - that they will create more potent sanctions for international law, and that they will find a means for ensuring the observance of treaties and for dealing with a violator thereof. These requisite sanctions and guarantees are not the figments of theory; they have existed hitherto, and they were applied in the present war. If not, why is Great Britain fighting, and why has the United States entered the war-to mention only two of the belligerents? What is needed is to reinforce these sanctions and guarantees in such a way that a State preparing to violate international law or treaties will be certain that it will have the whole civilised world against it, that if it proceeds in its contemplated act or remains refractory it will be ostracised from the family of nations and excluded from all commercial intercourse, that it will even have to encounter the armed forces of the united world and suffer all the consequences of certain defeat. The future hope of mankind, then, lies in close international co-operation, which undoubtedly can be established; the lessons and results of the war make such organisation imperative, whatever be the destiny of Alsace-Lorraine, and whether this or that State is to be neutralised or not. 


\section{CHAPTER XVI}

SOLUTIONS SUGGESTED: (d) PARTITION; ALTERATION OF BOUNDARIES, ETC.

Partition proposals-Language as a basis-Suggested union of Alsace with Baden-Division among German States-Frontier rearrangementThe pays messin to France and the rest neutralised-Alsace-Lorraine as part of a Rhenish-Alpine Confederation-Boundary readjustmentArbitration of the Pope suggested-Difficulties in these proposals: Division on basis of speech-Division on basis of sentiment-Division between German States-Lorraine as an independent State-Suggested confederation. The Rhine as a Franco-German boundary-Criticism of the view as to a Rhine frontier-Desideratum in fixing frontiers.

IN addition to the solutions considered in the preceding chapters, viz. the establishment of Alsace-Lorraine as an autonomous State within the German Partition Empire, and the creation of a neutralised in- proposals. dependent State, various schemes have been suggested which involve a partition of the territory or an alteration of its boundaries.

Thus it has been proposed that Alsace-Lorraine should be divided into two parts-the predominantly French-speaking country, and the predomin- Language antly German-speaking country-that the as a basis. former should be retroceded to France, and that the latter should continue to belong to the German Empire. On one occasion Maximilian Harden expressed the view that such districts of the Reichsland as were conspicuously French in character and speech might be restored to France in exchange for an African colony. And quite recently at the German majority

$$
285
$$


Socialist Conference held at Würzburg, October I4-I7, 1917, Herr Vetters of Giessen remarked that if it was simply a matter of the smaller French-speaking frontier districts, the Germans ought not to insist obstinately on retaining possession of them, if a great number of human lives could thereby be spared. Again, a more definite plan has been brought forward for separating Alsace and Lorraine as they are at present situated, and returning Lorraine to France, leaving Alsace to Germany. Further, it has been pointed out that, as Alsace would before the present war have probably voted, if the opportunity were offered, for inclusion within the German federation, and as Frenchspeaking Lorraine-comprising only some 450 square miles-would probably have preferred to be incorporated with France, a division and partition might be effected accordingly; such arrangement would leave the germanised part of Lorraine, which might have preferred to be brought into close association with the Lower Rhine provinces for reasons of commercial intercourse and on the ground of linguistic affinity.

Alsace, too- or the greater part of it that is German - might then have chosen to be united to the Grand Duchy of Baden, with which it has many

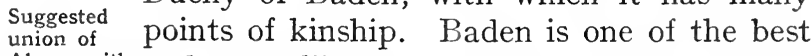
Alsace with and most liberally governed of the German
Baden.

States; it is a cradle of German liberalism ; its towns possess contented colonies of foreigners, and are becoming cosmopolitan in character; its arts, sciences, and social economy are in a progressive state of development. It is thought, therefore, that the Alsatians would have been quite satisfied with a union with Baden, and could have lived at peace, especially if many of the Prussian officials of Alsace were replaced by Alsatians and Badeners. 
Other partition schemes have quite recently been advanced in Berlin ; e.g. that Alsace should be allotted to Bavaria, and Lorraine to Prussia ; or that a threefold division should be made, assigning Lower Alsace to Bavaria, Upper Alsace to Baden, and Lorraine to Prussia. In support

Division among German States. of such plans it is pointed out that, whilst Alsace is much more closely related to Bavaria or Baden than it is to Prussia, German Lorraine, on the other hand, has close commercial connections with Cologne, and better understands and can more easily accommodate itself to the nature and characteristics of the Prussians.

A Swiss writer, discussing in the summer of 1916 the question of a rearrangement of the Franco-German frontier, observes: "The coral rag summits of the [Lorraine] plateau are national strate- rearrangegical points which become doubly valuable by the erection of forts. The eastern edge of the Côtes Lorraine should become, from natural causes, the first defensive line of France against Germany." He maintains that no suitable dividing line can be found in Lorraine owing to its geographical position between two large river basins, viz. that of south-west Germany and that of the Seine. "The chalk, clay, and marl strata of Lorraine may be regarded as the eastern edge " of the latter, or as the western edge of the former. Now, as it is this natural formation which in the past determined the independence of this transition territory, established formerly as the buffer State of the Duchy of Lorraine, he therefore recommends the revival of such a State to be delimited in accordance with geographical exigencies.

1 Basle Gazette, August 27, 1916; referred to by Sir Thomas Holdich, op. cit., pp. IIO-II. 
Again, it has been suggested that Alsace-Lorraine should be set up as an independent neutralised State, The pays after giving Metz and the pays messin to messin to
France and France and effecting certain boundary modiFrance and
the rest neutralised. the territory on the left bank of the Rhine wherein the Germanic dialect predominated, and also - for the sake of securing territorial unity-Upper Alsace, where, however, the use of French is increasing amongst the bourgeois classes. The boundaries would then be, on the east, the Rhine; on the west, a line coinciding approximately with the present frontier, subject to certain rectifications, e.g. in regard to the district of the old commune of Raon-lès-Leau, after which the line would follow the course of the Sarre Rouge as far as its confluence with the Sarre, and then the course of the latter as far as its confluence with the Moselle.

A remarkable proposal was brought forward in I 884 by a Saxon publicist ${ }^{1}$ as a means of solving the widely felt difficulties in regard to the anomaAs part of a lous position of the conquered Alsace-Lor-
RhenishAlpine con- raine. Like many other German writers and
federation. federation. politicians, he does not look with favour on the existence and multiplication of small States, and so he suggests that Alsace-Lorraine should be united to the neighbouring small States, Holland, Belgium, Luxemburg, and Switzerland, and that the whole should constitute a neutral Rhenish-Alpine Confederation. In this case the security of the frontiers of the German Empire might be ensured by causing the fortresses of Metz and Strassburg to be demolished, and by forbidding the construction of others.

1 M. Maass, Was soll mit Elsass-Lothringen werden (Leipzig, I884), p. 45. 
Writing in 1915, an English geographical authority ${ }^{1}$ proposes such a boundary readjustment as amounts to an entirely French solution of the problem. He holds that the frontier should be deter- $\begin{gathered}\text { Boundary } \\ \text { readjust- }\end{gathered}$ mined by considerations of national sentiment, ment. added to reasons of economic interests and geographical configuration. He points out that, whereas the forested Vosges form a real barrier in Alsace, yet French is steadily advancing towards the eastern slope, despite the fierce political hostility; and that, in view of all these circumstances, the eastern frontier of Alsace should be the Rhine, and such a reconstituted Alsace should go to France. In reference to the geographical features and the existence of German sentiment he says: "These include the lowland area of the Lorraine gate between the Hardt and the Vosges, the natural line of least resistance marked by the Zorn and the Kinzig valleys, and its complementary economic feature in the Rhine-and-Marne canal. This canal divides approximately the Alsace hop-lands from the Palatinate tobacco-lands, as the Saar divides the Lorraine hop-lands from the Palatinate grain-lands. So the frontier should run along the canal to the Saar, and then along the Saar to the point where the Moselle leaves the Luxemburg frontier. South of the canal and west of the Rhine there is no appreciable percentage of Germanic sentiment-in a population of $\mathrm{I}, 800,000$; and it is better that the appreciable percentage of Germanic sentiment west of the Saar should come under a Power with a genius for assimilation than that the at least equally appreciable percentage of French sentiment should remain under a Power with no such genius." "

1 L. W. Lyde, Some Frontiers of to-morrow (London, I9I 5), pp. 57-8.

2 Ibid., pp. 57-8.

I9 
Finally, as a way out of the seeming tangle a proposal has recently been brought forward by Herr Arbitration Herzberger's organ, the Swiss paper Neue of the Pope Zïrcher Nachrichten, that the Alsace-Lorraine suggested.

question should be submitted to the arbitration of the Pope, who would of course be able, subject to the limits of the submission, to choose from among the above-mentioned solutions.

That all these proposals are attended by greater or lesser advantages there can be no doubt; but it is Difficulties equally certain that they disregard or gloss in these over many outstanding difficulties and disproposals. advantages, which would prove to be an obstacle to a satisfactory, equitable, and permanent settlement from the point of view alike of the provinces themselves, the two contending claimants, and the rest of Europe.

The division of the provinces on the basis of speech and the assignment of the French-speaking portions Division on to France and the German-speaking districts basis of to Germany would be impossible becausespeech.

as we have shown in an earlier chapterthere is no clear line of demarcation between the two languages; if such an apportionment were attempted it would involve a chopping up of the country in such a fantastic manner that the result of the operation would be unmanageable for practical purposes. Moreover, great numbers of the people speak the two languages equally well; and many whose mother-tongue is the German dialect prefer French for cultural, literary, and social reasons. Indeed, language cannot safely be taken as the determining criterion for effecting a territorial division; it is not necessarily a true index of the sentiments, the sympathies, the aspirations, 
and the consciousness of national personality of a given population. ${ }^{1}$ Such a partition would not satisfy either France or Germany ; and it would be certainly repudiated by the Alsace-Lorrainers. We have emphasised more than once that, speaking generally, the Alsace-Lorrainers are neither French nor German; they are Alsace-Lorrainers with ideals of their own the fulfilment of which the great majority of them seek neither in France nor in Germany, but in AlsaceLorraine. There is undoubtedly a certain difference between the Alsatians and the Lorrainers in respect both of physical and mental characteristics; but a common unfortunate destiny for well-nigh half a century-not to mention an earlier and happier association-has brought them intimately together and has welded them into an almost homogeneous people; the union is quite as close as, if not closer than, the union of the different elements of Belgium or of Switzerland. M. Heimweh points out that during the period of protest," Upper Alsace, for example, which contained comparatively few French communes, returned protesting deputies to the Reichstag with the same persistence as Lorraine did, where half of the population were French; that the evasion from military service, the enlistments in the foreign legion, the number of the fallen at Tonkin and Dahomey, were all divided pretty equally between all parts of the Reichsland; and that the emigration statistics during, say, the twenty years $1871-1890$, show that there were just as many emigrants from the German-speaking districts as from the French-speaking localities. ${ }^{3}$ Thus,

1 On the question of language, see supra, chap. vii.

2 See supra, chap. $\mathrm{x}$.

3 J. Heimweh, La Guerre et la frontière du Rhin (Paris, 1895), pp. 78-80; referring to the Statistische Mittheilungen, xxiii and xxiv (Strasburg, I8934), published by the Ministry of Alsace-Lorraine. 
a partition based on language, or on earlier historical association, or on original nationality and race, whilst being ostensibly and superficially feasible and natural, would in reality be impracticable and artificial, and would amount to an arbitrary dismemberment of an organic whole. Furthermore, if a partition were effected, what would be the position of the part that remained German? Would it be a diminished Reichsland, or would it be made an autonomous member of the German confederation? Both alternatives give rise to difficulties.

Nor could a practical scheme of partition be arrived at on the footing of national sentiment and preference Division on for France or Germany, for the reason-as in basis of the case of the distribution of the two lansentiment. guages - that there is no definite dividing-line. The suggestion that Metz and the pays messin should be returned to France on the ground that this district is almost entirely French is weakened through the incorrectness of the reason given : for, in point of fact, Metz is not now predominantly French; the old town may still be so, but the new town is nearly all German; so that, speaking approximately, threefifths of Metz as a whole may be said to be German. Besides, the French revanche sentiment would scarcely be satisfied with the acquisition of Metz alone, if the rest of Lorraine and the whole of Alsace remained in the hands of Germany; for it is with Strassburg rather than with Metz that the French revanche sentiment-whatever there survived of it before the present war-had been associated.

The proposed division of Alsace-Lorraine between Prussia and one or two other German States (e.g. Bavaria and Baden) raises not only all the difficulties mentioned above, but the further difficulty in that it 
would arouse the jealousy and dissatisfaction of the South German States; and the provinces, which have long been an unhappy object of contention in European conflicts, would become an unhappy scrambling-ground for German States.

To set up Lorraine alone as an independent buffer State also gives rise to the various disadvantages incidental to separation; besides, it creates the further difficulty in reference to boundary delimitation. Many of the fatal defects of Lorraine as an independent the frontier established in $187 \mathrm{I}$ would be continued.

On the other hand, to do away as much as possible with small States altogether by combining AlsaceLorraine with, say, Belgium, Luxemburg, Holland, and Switzerland, and so establish Suggested ing a considerable confederation, is such an tion. absurd proposal that it is not worth discussion. That the small nations have justified their existence in the world and that it is a supreme advantage from all points of view - political, legal, cultural - to let them remain and protect them is admitted everywhere, except perhaps among certain sections in Germany. Writers, militarists, and publicists such as Clausewitz, Lasson, Treitschke, Bernhardi, and so on, look with contempt on small States (as on small armies) and would readily, if permitted, bring about their extinction.

Lastly, the proposal to readjust the boundaries in such a way as to make the Rhine the dividing-line between France and Germany has certain The Rhine important disadvantages. It was the fatal as a Francoaim of Napoleon III to secure for France boundary. the frontier of the Rhine. Do those who advance this suggestion mean that only that part of 
the Rhine which separates the present Alsace from Baden shall be the Franco-German boundary, or that the lower course of the river shall also form such $a$ boundary? In the case of the former alternativeassuming all the benefits claimed for a river-boundary -only a comparatively small section of the Rhine (about a hundred miles) would furnish the boundary, leaving Lorraine and Northern Alsace with the same defective frontiers as existed before the war of I870. The latter alternative implies the annexation to France of a considerable portion of Germany - the Palatinate and the Rhine Provinces-as well as interference with Luxemburg and Belgium. Even if Germany were overwhelmingly defeated and found herself at the mercy of France, there would be no valid reason, from the point of view of European policy, to take all this territory for the purpose of rounding off France. Moreover, what good reason is there, it has not inaptly been asked, to fix on the Rhine as the " natural" frontier of France rather than, say, the Elbe or the Oder, unless it be that the demand for the territorial extension of the Rhine is more modest and less impossible of realisation. But the fact that one claim is less extravagant than another does not necessarily make it a reasonable and legitimate one.

The question of the Rhine as a French boundary dominated the foreign policy of the Revolution and the Empire. It was an important feature The Rhine of the negotiations of the Treaty of Bâle
in earlier European (I795), as well as of those of the Treaty
politics. of Campo Formio (r797) and of the Peace of Lunéville (I80I), whereby France succeeded in acquiring the long-desired Rhine frontier. In November 18r3 Metternich and Nesselrode declared at Frankfort to De Saint-Aignan, the French minister, 
that in their view the Rhine was one of the natural boundaries of France: "Que les souverains coalisés étaient unanimement d'accord sur la puissance et la prépondérance que la France doit conserver dans son intégrité, en se renfermant dans ses limites naturelles qui sont le Rhin, les Alpes, et les Pyrénées, et que si ces principes étaient agréés on pourrait neutraliser, sur la rive droite du Rhin, tel lieu qu'on jugerait convenable où les plénipotentiaires de toutes les puissances belligérantes se rendraient sur-le-champ." After the defeat of Napoleon, however, in I8I4 and again in I8I5, a territorial rearrangement was effected in order to secure European political equilibrium. Under the Peace of Paris, I8I4, France was obliged to abandon the left bank of the Rhine; and under the Treaty of Paris, November 20, I8I5, she suffered further losses of territory-whereas Prussia gained considerable accessions beyond the Rhine, and, having thus acquired the hegemony in Germany, made a bid for the political hegemony on the Continent. A few months before his definitive downfall Napoleon is said to have remarked that the Rhine frontier is "un décret de Dieu" "; but, thanks to his ambition, Europe was compelled to disregard such " decree," and bring about a different arrangement.

Several recent writers, maintaining that the Rhine is a natural boundary necessary for the security and independence of European countries, point to the great part it has repeatedly played in The Rhine national struggles from the time of the struggles. Romans, and to the menacing predominance attained by the Power that took possession of the course of the river. Thus, a French historian writing soon after the

1 Letter to Fleury de Chaboulon, March I 8 I $_{5}$; referred to by C. M. Savarit, Frontiere du Rhin (Paris, I915). 
Franco-German War, and foreseeing the approaching preponderance of Germany, observes: "Sur les rives historiques du Rhin et au pied des montagnes qui se reflètent dans ses eaux, bien des races humaines, des peuples européens se sont heurtés; et il semble que la domination, ou au moins la prépondérance en Europe soit attachée à la possession de ces hauts sommets d'où l'on descend partout et de ce fleuve qui arrose et quelquefois ravage les pays les plus divers. Quand les Romains atteignirent le Rhin ils arrivaient à l'apogée de leur puissance, et quand ils l'abandonnèrent, leur empire tomba. Le véritable centre de la puissance de Charlemagne, qui s'étendait de l'Eyder au Garigliano et du Raab à l'Océan, était, entre la Meuse et le Rhin, à Aix-la-Chapelle; et les empereurs allemands, ses héritiers prétendus, menacèrent souvent de là l'indépendance européenne. Louis XIV, en ramenant la France au Rhin, conjura cette menace. La première République française, qui prit toute la rive gauche du fleuve, assura tout à fait cette indépendance, et le premier Empire français, en passant sur la rive droite, la menaça de nouveau à son tour. Les traités de 18 I5, qui partagèrent plus ou moins équitablement les rives du fleuve entre plusieurs peuples, avaient établi sur ce point un équilibre un peu factice, mais qui dura longtemps. La nouvelle puissance, en reprenant violemment presque tout le cours du fleuve sur ses deux rives, redevient la plus formidable puissance de l'Europe. Pour l'indépendance et la sécurité des peuples, le Rhin doit être une limite." '

But this argument, to which certain events of past European history certainly lend colour, savours of the post hoc propter hoc fallacy. It cannot for a moment

$1 \mathrm{~J}$. Zeller, Origines de l'Allemagne et de l'empire germanique (Paris, 1872), p. 2. 
be supposed when we consider the course of history, say, during the last two centuries, that the establishment of the Rhine as a boundary between France and Germany would have ensured Criticism of peace and arrested the view as peace and arrested the territorial ambitions to a Rhine of this or that Power. Under Louis XIV, for example, little importance was attached to natural defences. ${ }^{1}$ The cause of aggression is not the absence of a natural boundary like the Rhine, but, on the one hand, the absence of a properly constituted society of nations governed by an international law that cannot be set aside at discretion, and on the other hand the accumulation of armaments, and the obtuseness of peoples in their subservience to military fanatics. In these circumstances a natural boundary, involving a greater or less obstacle, is scarcely more effective than a purely artificial boundary of stakes and stones, protected by trenches and fortifications. Moreover, the contention that the Rhine is the most suitable Franco-German boundary is disputed by an eminent authority on boundary delimitation. Thus, Sir Thomas Holdich, writing in I9I6, points out that it is the Rhineland fortresses, and not the Rhine itself, that protect the western frontiers of Germany from France, ${ }^{*}$ and goes on to say: "Many people hope that the Rhine will be the new boundary between France and Germany. But the Rhine is no barrier from the military or political point of view. Its banks offer no serious means of defence, the population of the Rhine valley on either side the river being of the same ethnical type which spread down originally from Alpine regions. The western water-parting of the Rhine basin, where

1 Cf. C. Lecomte, Les ingénieurs militaires en France pendant le règne de Louis XIV (Paris I904).

2 Political Frontiers and Boundary-making, p. 129. 
that water-parting is caused by the Vosges Mountains, lends itself far better to the ideal of a frontier barrier, and could readily be rendered impregnable by modern military engineering." " The same writer has observed more recently: "The Rhine boundary between Germany and France was unsatisfactory because the Rhine rift is connected by easy lines of approach from the German side, whilst France possesses no such easy approach lines from the Lorraine plateau, where the drainage, represented by the Meuse and Moselle, runs northward, whilst the plateau is buttressed on the east by the Vosges and the Hardt Mountains, which offer no such facilities. Thus the Rhine became geographically a German river, and has always been claimed as such by Germany. The Meuse-Moselle plateau has, historically, been an effective barrier between east and west because of this inaccessibility from the east, and also because of the character of its wild, uncultivated, and forest-clad uplands. It has, indeed, proved almost as great a barrier to French expansion as to German aggression." " This view is supported, from another standpoint, by Mr. J. W. Headlam, who states the results of his observation in the following terms: "No one, indeed, who has ever stood on the slopes of the Black Forest and looked across the magnificent valley, sheltered by the hills on either side, through which the Rhine flows, can doubt that this is all one country, and that the frontier must be sought, not in the river, which is not a separation, but the chief means of communication, but on the top of the hills on the further side." s

1 Political Frontiers and Boundary-making, p. 290.

${ }^{2}$ Article in New Europe, February 8, 1917, p. r ro, entitled New Political Boundaries in Europe: Alsace-Lorraine.

3 J. W. Headlam, Bismarck. Heroes of the Nations Series (New York: London, I899), p. 375. 


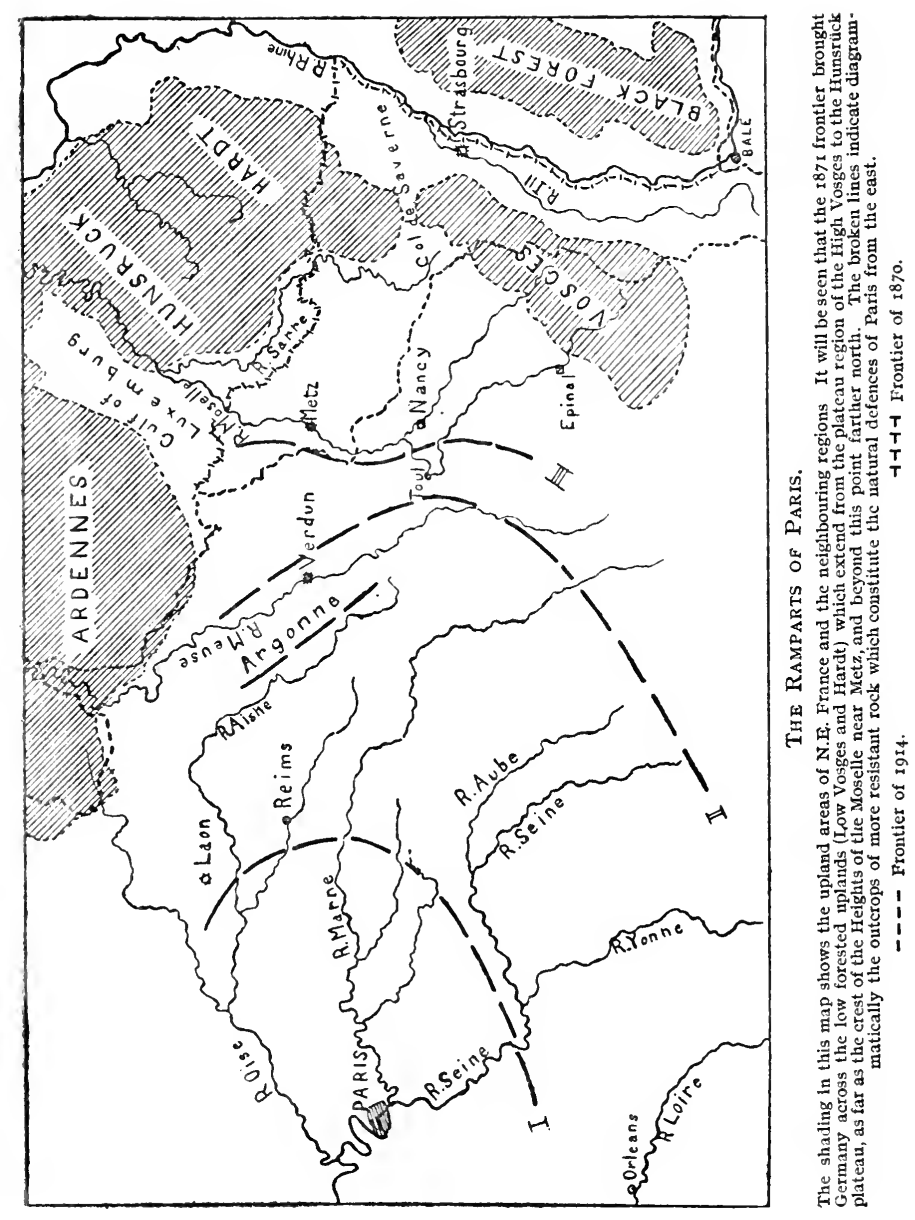



The main desideratum in fixing the Franco-German boundary, as in adjusting the fundamental issue relative to Alsace-Lorraine, is to consult the ${ }_{\text {Desideratum }}$ wishes and circumstances of the populations ${ }_{\text {Desideratum }}^{\text {in fixing }}$ directly concerned, and not to attempt to frontiers. settle these questions merely by means of secret negotiations in a council-chamber and by the arbitrary and independent tracing of maps. A carefully and impartially organised referendum is, then, a condition indispensable to the eventual settlement. This has already been emphasised more than once in the preceding pages. A fuller consideration of the question of a plebiscite may, therefore, suitably conclude the present work. 


\section{CHAPTER XVII}

\section{THE QUESTION OF A PLEBISCITE}

Plebiscite for Alsace-Lorraine necessary-Examples of plebiscites-Cases of annexation without a plebiscite-Anglo-American practice-Juristic opinion-Grounds of support of plebiscite-Grounds of objection to plebiscite-Each case to be considered on its merits-Alsace-Lorraine a suitable case-Prevailing views as to self-determination of peoples Alsace-Lorraine desirous to decide its own fate-Alsace-Lorraine evez against war as a solution-Opposition to plebiscite by France, Germany, and leading Alsatians-Criticism of objections-A real difficulty : presence of immigrants and absence of emigrants-Compromise necessary-Organisation of plebiscite-Persons who should vote-Probable result-Essential condition for the future.

THE key-note of this question has been expressed thus by a French writer " : "We may admit that France

Plebiscite has only mediocre rights to Alsace-Lorraine, for Alsace- after having sold it to obtain peace. But

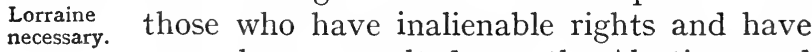

never been consulted, are the Alsatians and Lorrainers themselves." During the last hundred years the view has been gaining ground that the annexation of territory with a considerable population is illegitimate and invalid without their consent expressed on a plebiscite. A few precedents may here be recalled.

An early instance is that of 1552 , when Henry II of France, after taking from the German Empire Examples of the three Bishoprics, Metz, Toul, and Verdun, plebiscites. appears to have submitted their proposed annexation to a vote of the inhabitants. The Bishop

1 C. Andler, Le Prince de Bismarck (Paris, I899), p. 308.

2 Phillipson, Termination of $W$ ar and Treaties of Peace, pp. 282 seq. 
of Verdun said to his people, "que le roi de France était venu comme libérateur, qu'il voulait traiter les bourgeois comme de bons Français et que, bien éloigné d'user de mesures de rigueur, il en appelait au vote libre du peuple." 1

The procedure was adopted, again, by the French Revolutionary Government in several cases." Thus, during the war between France and Sardinia, I792, General de Montesquiou having invaded Savoy and taken possession of Chambery, September 24, the communes were asked to elect delegates (October I4) for the purpose of discussing and voting on the question of annexation. A great majority having voted in favour thereof, the Convention accordingly decreed, November 27, the union of Savoy to the Republic, of which it formed the eighty-fourth department. ${ }^{3}$ On September 29, I792, Nice was taken by General Anselme, who met with no opposition from the troops of the King of Sardinia ; whereupon a local assembly was summoned, and it decided by a large majority in favour of annexation to France." Similarly, after Mayence was entered by the French troops, October 2 I, I792, and the greater part of the territory now forming Rhenish Bavaria was occupied, an assembly was constituted, and it resolved on union with France ; accordingly the Convention decreed, March 30, 1793, that the towns and communes of Mayence, Worms, etc., were to become part of the French Republic. ${ }^{5}$

1 Cf. E. Ollivier, L'Empire libéral (Paris, I 895 ), vol. i. p. 165.

2 J. Heimweh, Droit de conquête et plébiscite (Paris, 1896); R. de Card, Les Annexions et les plébiscites dans l'histoire contemporaine in Études de droit international (Paris, I890).

3 Cf. V. de St. Genis, Histoire de la Savoie (Chambéry, I S69), vol. iii. pp. 137 seq.

4 J. B. Toselli, Précis historique de Nice depuis sa fondation jusqu'en $\mathbf{1} 860$. 4 vols. (Nice, I867-9.)

5 A Chuquet, Mayence (Paris, I892). 
Napoleon III, who proclaimed the right of peoples to choose their own masters, adopted the system of plebiscite in the case of the annexation of Nice and Savoy to France (treaty of March 24, I860, Art. I.), ${ }^{1}$ and in the cession of Venetia and its incorporation with Italy (treaty of October 3, I866, plebiscite, October 2I, 22). Other plebiscites established the union of Parma, Modena, Tuscany, and Emilia to Piedmont and Lombardy, March II, I2, I860 ; Sicily and the Kingdom of Naples to Italy, October $2 \mathrm{I}$, I860; Umbria and the Marches, November 30 ; Rome and its territory, October I870. Thus the principle of voluntary incorporation played a noteworthy part in the creation of a new Power-Italy.

Under the Treaty of Paris, August I0, I877 (Art. I.) the island of St. Bartholomew (Antilles) was ceded by Sweden to France, subject to the express consent of its population.

In the treaty of peace of October 20,1883 , between Chile and Peru, it was stipulated that the territories of Tacna and Arica should remain in the possession of Chile for a period of ten years, and that at the end of this term a plebiscite should decide whether they were to remain definitively annexed to Chile or were to be restored to Peru. Numerous difficulties arose between the two States in regard to the organisation of the referendum; negotiations between them were more than once commenced and then broken off. ${ }^{2}$

On the other hand, there have been several striking cases of annexations in which the plebiscitary procedure was not adopted : e.g. the dismemberment and

1 G. Cogordan, La nationalité au point de vue des rapports internationaux (Paris, I890), pp. 344-56; Revue des Deux Mondes, March I, I896.

2 H. Bonfils, Droit international public (Paris, I912), p. 372 ; Revue de droit international (Bruxelles), vol. xxix. (1897), pp. 660 seq. 
partition of Poland in I772, I793, and I795; most of the treaties concluded by Napoleon, notably the Peace of Tilsit (July, I807), which deprived Prussia of an immense extent of territory; $\begin{gathered}\text { Cases of } \\ \text { annexation }\end{gathered}$ the treaties of $I 8 I 5-a$ counterblast to the without a Napoleonic conquests-which effected a great territorial readjustment in Europe; the Treaty of Frankfort, I87I. It may be added that in the Treaty of Prague, August 23, I866, between Austria and Prussia, it was stipulated (Art. V) that Austria should transfer to Prussia Schleswig and Holstein (the rights over which having been acquired by the Treaty of Vienna, October 30, I864), with the condition that the population of the northern districts of Schleswig should be ceded to Denmark if, by a free vote, they expressed a wish to that effect. But Prussia refused subsequently to carry out this plebiscitary provision.

Anglo-American practice in the past has been against the plebiscite. The United States has nearly always refused to resort to the procedure in the case of her territorial acquisitions, whether Anglothey were forcible annexations or were the practice. outcome of amicable cessions by means of negotiation. On one occasion the inhabitants of the Danish West Indies were allowed to vote on the question of annexing the islands to the United States; but Mr. Seward, the Secretary of State, protested against this concession.' As for Great Britain, Lord Salisbury once declared in the House of Lords that " the plebiscite is not among the traditions of this country." "

Thus the practice of States has been far from uniform; and this divergence of practice is reflected

1 Cf. F. Bancroft, Life of William H. Seward (New York: London, 1900), vol. ii. pp. $4^{83-5}$.

2 (June I9, I890). Hansard, 3rd series, vol. cccxlv. p. I3II. (In regard to the cession of Heligoland.) 
in the opinions of international jurists. There is no room here to consider these in detail, but we may Juristic refer to one or two representative pronounceopinion. ments. M. Acollas, who is a French civilian as well as a writer on international law, emphasises that there can be no legitimate dismemberment or annexation of a country without the free consent of the people who are to be separated and of those who are to be united thereby: "Il ne peut y avoir de démembrement légitime que par la volonté propre de ceux qui se séparent; d'annexion légitime que par la volonté réciproque de ceux qui s'unissent." Bluntschli, who showed himself a staunch advocate of the progressive law of war as against the extravagant pretensions of Von Moltke, ${ }^{2}$ observes that a cession of territory presupposes the recognition of the act by its people, that such recognition need not be express and voluntary, but may be tacit and involuntary, manifested by their submission and obedience to the acquiring Government by reason of considerations of necessity, although to secure voluntary adhesion is undoubtedly the best policy. Art. 286 of his notable work on international law is to this effect: " La validité d'une cession de cette nature présuppose pour le moins la reconnaissance par la population jouissant des droits politiques, laquelle habite le territoire cédé et passe à un nouvel Etat. Observation: La reconnaissance pour la population jouissant des droits politiques est indispensable parce que celle-ci n'est pas un objet

1 E. Acollas, Manuel du droit civil. Commentaire philosophique et critique du Code Napoléon (Paris, 1868); cf. the same writer's Le Droit de la guerre Paris, 1888).

2 Von Moltke to Professor Bluntschli, dated Berlin, December II, I880; translated by Prof. Holland, Letters to The Times upon $W$ ar and Neutrality (London, 1909), pp. 24-9; see also Phillipson, International Law and the Great War (London, I9I5), pp. I38-4I. 
privé de volonté et de droits qu'on puisse aliéner, mais un élément vivant de l'Etat et que l'opposition de la population rend la prise de possession pacifique impossible. Mais la reconnaissance de la nécessité suffit, et l'adhésion libre et joyeuse de la population, bien que désirable, n'est pas nécessaire. La nécessité à laquelle on se soumet contre sa volonté et en maugréant, mais en reconnaissant qu'on ne peut faire autrement, fonde elle aussi dans la vie politique un nouveau droit; cette reconnaissance est déjà impliquée par l'obéissance, qu'on montre envers le nouveau gouvernement et dans la cessation de toute résistance. Par contre, l'adhésion libre constitue une approbation active de la cession. Sans aucun doute, il vaut mieux que l'État qui acquiert un nouveau territoire obtienne cette adhésion et qu'il ne soit pas obligé de se contenter provisoirement de la reconnaissance par nécessité." '

Those who support the practice of plebiscite maintain that the mere might of the stronger ought not to be allowed to prevail, that the circumstances in which we now live are different from those of earlier ages when might was deemed to be support of plebiscite. right, that the public opinion of the civilised world has manifestly changed, that the general democratic movement may not be disregarded, that popular suffrage is now almost everywhere the fount of political authority, that the sovereignty of the people is now the governing factor in the political and social life of nearly all civilised States, and that it is now being strikingly asserted in countries that were hitherto subjected to an autocratic or oligarchical government.

Those who object to the practice hold that it is not likely to become a recognised part of international

1 J. C. Bluntschli, Das moderne Vōlkerrecht (French trans.-Le Droit international codifié), $\S 286$. 
usage, in that it is not capable of acquiring universal applicability, that in some cases it may produce more Grounds of evils than it is intended to avoid, that in a objection to forcible annexation a powerful State will replebiscite.

pudiate the procedure if it suspects that a vote of the people will be unfavourable, and will be disposed to resume hostilities for the purpose of effecting a complete subjugation of the recalcitrant parties, that the vote of a majority is not necessarily the best, that such a vote would force the minority - which might be almost equal in numbers to the majority-to accept a destiny contrary to its will (a condition of things which the very procedure is meant to obviate), and that there is no certainty that the people would give their votes freely, uninfluenced by malpractices and sinister motives. The opponents point further to the case of the American secession, as being analogous to a case of cession in regard to the will of the population; they say that had the plebiscite been resorted to in I86I, there would, indeed, have been no American civil war, but also there would have been no United Statesfor a majority in the Confederate States of the South would undoubtedly have voted in favour of separation.

However this may be, even if the universal applicability of the practice be doubtful, each case must be taken on its merits-for there certainly are

Each case to be considered on its merits. cases in which the plebiscitary procedure would be eminently fitting, desirable, and practicable. Moreover, the present war has had a great influence on the world's opinion, and particularly on the conception of the interrelation and interdependence of States. Some of the objections to the plebiscite become untenable in view of the now accepted principle, which has in these days so strikingly been put into practice, that third Powers have the right 
to intervene in the affairs of two given States, when one of the latter violates the law of nations or is about to take an unconscionable advantage of the other, contrary to what is manifestly right and just. Other objections will lose their force if the contemplated league of nations becomes a reality.

Whatever cases may be cited as being unsuitable for the application of a plebiscite, there is no doubt that Alsace-Lorraine is a suitable case. On the one hand, there are two parties contending for its possession; on the other hand, there is a territory with a highly civilised population

AlsaceLorraine a suitable case. possessing a distinctive soul and personality and a view of their own. What is, therefore, necessary is to make their will known, and to give them an opportunity of formally registering it in favour of one of various courses: to remain within the German Empire as an autonomous State, to return to France, to become a neutralised independent State, or some other preferred solution.

We have already referred to the various pronouncements of governments, ministers, and other publicists as to the necessity of the principle of self- Prevailing determination of peoples - and the Alsace- views as to Lorrainers undeniably constitute a " people" $\begin{gathered}\text { self-deter- } \\ \text { mination }\end{gathered}$ in every rational sense of the term. These of peoples. pronouncements are supported by other views representative of increasing elements in democracy: e.g. by the British Labour Party, ${ }^{1}$ by the French Socialist Party, and also by German Socialist circles-Herr Katzenstein (of Stralsund), supported by Herr Glattbach (of Mülhausen), brought forward a motion at the Socialist Conference held at Würzburg, October I4, I9I7, on behalf of the Socialists of Nuremberg, Würzburg, and the sixth division of the Palatinate (repre-

1 Daily Telegraph, October 3r, 1917. 
senting the most moderate section of the Majority Party) in favour of allowing a referendum to the people of Alsace-Lorraine. The American declaration of policy on this point announced on October I9, I9I7, is to this effect: " President Wilson is determined to uphold the rights of small peoples, and adhere to the general principle that no people shall be forced to live under a ruler under whom they do not wish to live. Just how far this idealistic rule will be enforced depends entirely upon the conditions existing at the close of the war."

Alsace-Lorraine has throughout been desirous of deciding its own fate. Alike during the period of Alsace- protest and during the national movement Lorraine
desirous of its people have time and again called for deciding its a plebiscite. Writing at a date midway beown fate. tween the Franco-German War of 1870 and the great war of I9I4, one of Alsace-Lorraine's stoutest defenders repudiated the various proposals that had from time to time been advanced by friends of AlsaceLorraine for settling the question, without consulting the people themselves. He observed that to suggest neutralisation, exchange for a French colony, purchase, or even pure and simple retrocession to France is to dispose arbitrarily, once more, of two provinces containing a million and a half of human beings; that to proceed in this measure is to adopt the way of the Germans, who also thought they were doing the population a service by annexing them without letting them express their view. He asks the friends of his country to deny themselves the pleasure of thus giving happiness to the people, who, having learned by experience, desire to pronounce themselves on their own destiny. "Que nos amis veuillent donc bien renoncer à la satisfaction de nous octroyer le bonheur. Instruits par 
l'expérience, nous demandons à pouvoir prononcer nous-mêmes sur notre propre destinée." ' Similarly, some twenty years later, and before the present war, M. Auguste Lalance, of Mülhausen, a former deputy of the Reichstag, urged that the people of Alsace-Lorraine should be permitted by means of a free vote to decide their own fate. ${ }^{2}$ And so on with other representative views.

Indeed, Alsace-Lorraine has all along been most anxious that the question should be settled by pacific means, and that war on its account should be avoided. Mr. Jordan, who conducted a $\begin{gathered}\text { Alsace- } \\ \text { Lorraine }\end{gathered}$ personal inquiry on the spot in I9I3, says ever against that in all Alsace he found only two persons solution. who thought that the ultimate solution was to be found in war. He writes in the following terms as expressing the views of leading Alsatians and the attitude of the majority of the population: "War is the worst possible solution of our problems, because war is no solution. With war there is never a solution of any question. Alsace has been part of Germany, of Austria, of France, and now of Germany again. If France should gain Alsace by war, it would be only the beginning of another war, and so on without end. ... Every solution implying war is to be rejected. No definite solution could result from a FrancoGerman war, by which Alsace would find herself cut into two parts, each to destroy the other. A war, whatever its result, provokes always the desire of revenge, and leads to indefinite international disorder, in which the antagonism among different elements would be greatly intensified. . . A Franco-German entente would necessitate for Alsace-Lorraine a govern-

1 J. Heimweh, Triple Alliance et Alsace-Lorraine (Paris, I892), p. I3I.

2 Cf. Bourdon, L'Énigme allemande, p. 471 ; Eng. trans., p. 357. 
ment according to its own will. It would thus destroy the worst obstacle to the pacification of Europe, and open to civilisation new lines of progress." 1

The only way to ensure the pacification of Europe, so far as it depends on the solution of the Alsace-Lorraine problem, is to give the Alsace-Lorrainers an opportunity of deciding their destiny definitively and formally by means of a plebiscite.

Now we have already seen that Germany is opposed to a plebiscite, not necessarily because she fears an Opposition adverse vote, but on the ground that there is to plebiscites legally no "question of Alsace-Lorraine," Gy France, and that there is no lawful justification for and leading a referendum, seeing that the provinces were Alsatians. transferred to her in perpetuity by the Treaty of Frankfort, and that they could no longer, after that act, concern any other Power but herself. On the other hand, the French, as well as certain leading Alsatians, object to a plebiscite for different reasons. In the first place, they hold that the return of Alsace-Lorraine to France would be merely a recovery or reunion, and not a cession or annexation : France is to regain her property just as stolen goods are taken from a thief and restored to the true owner. "La France," says M. Helmer, " reprend son bien, qu'elle retrouve dans la main du possesseur de mauvaise foi, comme je puis reprendre ma bourse à celui qui m’en a dépouillé.'. ' Similarly, M. Wetterlé observes: "Who to-day would wish to sanction that insult should be added to injury in proposing to surround with ridiculous formalities the restoration to France of her property, the return of the AlsaceLorrainers to the true mother-country? . . . I am

1 op. cit., pp. 96-8.

2 France-Alsace, pp. ${ }_{5} 5,159$. 
not in doubt as to the result of a referendum in AlsaceLorraine if one were to be organised. By a crushing majority my compatriots would affirm their desire to be relieved for ever from those masters who have so cruelly tortured them. But it would be an attack on the honour of France to force her to make an electoral bid to regain the heart of her children, and on the honour of Alsace-Lorrainers to make them to put up their heart for public sale." I The republican newspaper of Paris, Le Temps, condemned, in its issue of August II, I9I7, the submission of the majority to the minority French Socialists in accepting a plebiscite in their reply to the Stockholm questionnaire, on the ground that recourse thereto " would mean the casting of an odious doubt on the patriotic conscience of the Alsace-Lorrainers." The radical paper, Le Matin, of August 22, I9I7, likewise rejects a plebiscite, and says that the people of the annexed provinces cannot admit that their character of Frenchmen should be questioned.

Again, it is contended that the protests of the Alsatian and Lorraine representatives made in I87 I do not now need confirmation, and that they are still applicable and valid." "We will have," says M. Georges Weill, ex-deputy for Metz in the Reichstag, " no preliminary plebiscite, since that would be an abjuration of the protests of the past, an insult to our feelings, and a sanction of the greatest outrage of modern times." " A similar view is expressed by MM. Lichtenberger." And M. Helmer holds that to agree to a plebiscite would be an admission that AlsaceLorrainers might to-day deny the solemn and unani-

\footnotetext{
1 Fortnightly Review, November I9I 7, pp. 799, 800.

2 Le Matin, August 22, 1917.

3 The Observer, February 3, 1918.

- Op. cit., p. 83 .
} 
mous declaration of their deputies in I87I." " $\mathrm{La}$ seule base certaine de la réunion de l'Alsace-Lorraine à la France doit être la manifestation de Bordeaux." '

Next, it is urged that the acceptance of a plebiscite would be a tacit recognition of the effects of violence. ${ }^{3}$

This would, too, assume the validity of the Treaty of Frankfort, which is considered by many Frenchmen and Alsatians to be null and void $a b$ initio, and by others to have been abrogated on the outbreak of the present war. ${ }^{4}$

There is really no need to examine these objections in detail. The untenability of most of them has Criticism of already been shown. It will be sufficient to objections. say that Germany acquired a legally valid title to the provinces by the Treaty of Frankfort, which remains binding until it is superseded or modified by another treaty; that the declarations of $187 \mathrm{I}$, whatever moral weight they had, had no such legal force as could invalidate the transaction solemnly and voluntarily effected by the declarants' recognised Government; that the return of Alsace-Lorraine to France would not be a "recovery " or "restoration" in the sense alleged, but an annexation-to claim otherwise is to prevaricate just as much as the Germans did in I870 when they attempted to justify the dismemberment of France on the ground that it was necessary as a "protective guarantee"; that the violence of I87I would be repeated if Alsace-Lorraine were annexed to France contrary to the wishes of the population; and that the only way to find out what their true wishes are is to ask them, and to ask them cannot surely be an "impiety " or an "insult," when

1 France-Alsace, p. I56.

2 Ibid., p. 164.

- Ibid., and also the view of M. Barrès, in the preface, p. ix. 
the object of asking them is merely to settle a disputed or doubtful point.

There is, however, another objection that has more force, viz. that a plebiscite would not be fair owing to the presence of German immigrants and the absence of Alsatian and Lorraine emi- A real grants. In I87 I the population of Alsace- presence of Lorraine was about $x, 500,000$. Under the and absence Treaty of Frankfort the practice of option of emigrants. was adopted ${ }^{1}$; the native inhabitants (excluding women and minors) had to choose between French and German nationality by September 30, I872. There were about 160,000 options, of which more than a half were annulled because they were not followed by effective departure within a reasonable time. The emigration of natives and the immigration of Germans began in I87I and continued in the subsequent years. We may quote some figures from the Official Manual of Statistics of Alsace-Lorraine to show the loss in population during the first twenty-five years after the annexation :

From I87I to 1875 the number of emigrants exceeded the number of immigrants by 70,970 .

From I 875 to 1880 the number of emigrants exceeded the number of immigrants by 35,835 .

From I880 to $\mathbf{1 8 8 5}$ the number of emigrants exceeded the number of immigrants by $59,3 \mathrm{I} 2$.

From $\mathrm{I}^{8} 85$ to $\mathrm{I} 890$ the number of emigrants exceeded the number of immigrants by $37,99 \mathrm{I}$.

From I890 to I895 the number of emigrants exceeded the number of immigrants by 34,534 .

Thus, from I 87 I to I 895 the number of emigrants exceeded the number of immigrants by $238,6+2$.

1 See Phillipson, Termination of $W$ ar and Treaties of Peace, pp. $296 \mathrm{seq}$. 
As these figures show only the difference between the number of emigrants and that of immigrants, it is clear that the actual number of emigrants was much greater than the numbers shown in the above table. It is roughly estimated that down to the year I9oo there were about 500,000 emigrants and about 300,000 German immigrants; and during the subsequent period the numbers on both sides increased to some extent, though not proportionately-perhaps 600,000 represents the approximate number of emigrants up to date (though a much larger number, even as high as a million, has been stated by M. Georges Weill ${ }^{1}$ ). In any event, allowing for errors in the estimate, it is contended that, to determine the true voice of AlsaceLorraine, we must not confine ourselves to its present population, but we should also take into account the emigrants and their descendants. Furthermore, it is thought that it would be unfair and unjust to ask the large contingent of German immigrants to say whether the country in which they have settled should be French or German.

Thus the principal difficulties that arise relate, on the one hand, to the classes of persons who should be compromise permitted to vote, and on the other to the necessary. organisation and supervision of the plebiscite machinery. A compromise appears to be the only way to overcome these obstacles; and such a scheme as the following would be an equitable one, and by its means a fair expression of Alsace-Lorraine opinion could be ensured.

First, the entire organisation of the voting should be entrusted to a mixed commission including neutral

1 The Obsever, November 18, 1917; February 3,1918. With the estimate of $M$. Weill we may compare that of MM. Lichtenberger, who give the number of enigrants, down to the year 1910 , as 500,000 ; op. cit., p. 17. 
members, or to an entirely neutral commission guaranteeing liberty and secrecy of the poll and protection from bribery, duress, and other irregular practices.

Organisation of plebiscite.

Secondly, we have to bear in mind that the overwhelming majority of the population are AlsaceLorrainers, and not German immigrants; and so, having regard to their solidarity, their consciousness of national personality, and their common destiny for nearly half a century, we must conclude that it would be better to poll the votes of the qualified population as a whole, rather than divide up the country into a number of territorial units and take the poll of each of these separately. ${ }^{1}$ Subject to slight frontier emendations that may be shown to be imperative, AlsaceLorraine should not be chopped up, but should stand or fall together-an inference that presents itself irresistibly from our previous exposition of the entire problem and its various implications.

Thirdly, the persons qualified to vote might include the following: (I) the domiciled native male inhabitants who are of legal age; (2) the Persons who domiciled native unmarried women or widows should vote. who are of age (since the nationality of a wife is that of her husband, it would be either supererogatory or impolitic to give them separate votes); (3) the domiciled native male orphans who have reached military age, if this is lower than the ordinary legal age ; (4) the domiciled naturalised inhabitants of age who are neither of French nor German origin ; (5) German immigrants-men, unmarried women, and widowswho have established, say, a ten years' domicile ; (6) Alsatian and Lorraine emigrants-men, unmarried

1 A division into small areas is suggeted by A. J. Toynbee, Nationality and the War (London, 1915), pp. 42 seq. 
women, and widows-who have emigrated, say, within the last ten years. The claim sometimes advanced that all the German immigrants should be disqualified, and that all the Alsace-Lorraine emigrants, and their descendants, should be qualified, is unfair, irrational, and inexpedient; for we have to determine the will of Alsace-Lorraine as it is at the date of the plebiscite, and not as it was in I87I. We know that in I87I it went over to Germany most reluctantly; but in the period between then and now the country has in many respects been revolutionised; and it is its present view and feeling that we have to ascertain.

Fourthly, before resorting to this plebiscitary procedure it would be well to wait, say, two or three years, until the passions aroused by the war have been cooled a little, and the thoughts of the people have been collected sufficiently to allow of an undisturbed consideration of the choice to be made.

It is audacious at all times to indulge in prophecies, and especially so in the case of the present complicated Probable problem, which the war has rendered all the result. more difficult. None the less, mindful of the facts, considerations, and conclusions presented in the foregoing chapters, we venture to express our belief that a plebiscite organised before the present war on the lines suggested would have resulted in favour of autonomy within the German Empire, and if organised now will result in favour of neutralised independence.

Be this as it may, whatever result is arrived at it will be only a dangerous, patched-up solution unless

Essential condition for the future.

there be a general reconciliation of the warring peoples, and such a change in the position and relationships of the society of States as will more effectively safeguard international law and minimise the possibility of war. 


\section{N D E X}

\section{Abwehrgesetze $\mathrm{I}_{6}$}

Acollas, plebiscite, on 306

Agénor de Gasparin, neutralisation of Alsace-Lorraine 272

Agriculture 43, 44

Albert, King of the Romans I I 5

Alfonso XII I 63, 2 I 7

Alsace. See also heads for various topics

French Revolution, at $59-60$

Middle Ages, in 55, I I 7

part of Germany till seventeenth century 56

Thirty Years War, in 56

union with France 60

'Alsace for the Alsatians' I63, I73, I $84,26+$

significance of 188

Alsace-Lorraine. See also headingsrelating to the various topics annexation in $187 \mathrm{I}, 20,6 \mathrm{I} \mathrm{seq}$.

See Annexation in $187 \mathrm{I}$

area of, in earlier history 19,20 when annexed by Germany $3+$

attitude of, outbreak of the war, at $207 \mathrm{seq}$.

towards France before the war $199 \mathrm{seq}$.

See also Nationalist movement

bone of contention, long a I9

' challenge-cup of Europe,' as 30

claims of Germany to II $2 \mathrm{seq}$.

See Claims of Germany to Alsace-Lorraine

cockpit of Europe, as a 30

declaration of the two Chambers (I9I 7), $209 \mathrm{seq}$.

description of $34 \mathrm{seq}$.

French attitude towards $21+s e q$.

See French attitude towards Alsace-Lorraine

history $49 \mathrm{seq}$. See History

nationalist movement I $84 \mathrm{seq}$.

See Nationalist movement

new generation, attitude of 203

personality of 202
Alsace-Lorraine-continued

position of, in earlier history 19 problem of

See Problem of Alsace-Lorraine proposals as to its fate after annexation $86 \mathrm{seq}$.

protest of $187 \mathrm{I}$ against annexation $98 \mathrm{seq}$.

protest of deputies (I 874 ) I 84 seq. régime in I $55 \mathrm{seq}$.

See Régime in Alsace-Lorraine status of $155 \mathrm{seq}$.

views and aspirations of $184 \mathrm{seq}$.

See Nationalist movement

views and feelings of people, doubtful indications of 203-7

Althoff, quoted $\mathrm{I}_{3}$

Amnesty 83

Annexation in $18_{7}$ I, 61 seq.

amnesty $\mathrm{s}_{3}$

announcement of 63

boundary commission So-8I canalisation of the Moselle 84 ecclesiastical authority $8_{3}$

effects of $20 \mathrm{seq}$., I IO

German attitude as to $79-80$

grounds for

See Claims of Germany to Alsace-Lorraine

imperial province, made an 9.4 navigation on rivers and canals 84

option of French subjects 82 pecuniary deposits 83

proposals as to fate of provinces $86 \mathrm{seq}$.

protests against 65

Alsace-Lorraine deputies in I 87 I, of $98 \mathrm{seq}$.

Germany, in 86

various other $\mathrm{IO}_{3} \mathrm{seq}$.

public records 83

rights of inhabitants of ceded territory $8 \mathrm{I}$

territorial lust of Germany $\mathbf{I}_{4} \mathbf{I}$ seq.

various matters regulated $84-5$ 
Area 34

Arendt 153

Argyll, Duke of 147

Asquith, Mr., Alsace-Lorraine as cause of the war, on 29 reannexation to France, on 236

Austria, aim in 1815,60

Autonomy for Alsace-Lorraine, demand of $194-7$

Frencl views 265 government, form of 267 movement for

See Nationalist movement nationalist ideal $263^{-4}$ plebiscite following $269-7 \mathrm{O}$ position as autonomous State 268-9

recent German opinion 265-7 refusal of, reasons for $172-4$ suggested in 187 I $93^{-4}$

Baden, suggested union of Alsace with 286

Bâle, treaty of 294

Ballon d'Alsace 37

Barrès 202, 205, 206, 215 quoted 234

Barthou 230

Bebel 86

Beer, manufacture of 44

Belfort $77,78,79$

Benedetti 62 gap of 37

Berckheim 130

Bernhard of Saxe-Weimar 56

Bernhardi $14 I$

Bethmann-Hollweg 169, 172, 2 I I

Beust, Count von 66

Bismarck, Belfort, concession as to $7^{\circ}$

dictatorial régime in AlsaceLorraine, on I $5^{8-9}$

doubt as to territorial demands 67

effects of annexation of 1871 , on 110

European intervention feared by 65

Ferrières, at 63

germanisation, view as to $95^{-6}$ indemnity, concession as to 70

Metz, doubts about 97

neutralisation, on 273

policy as to annexed provinces 88 seq., 95

political necessity of annexation, on 137

proposed treaty with Benedetti published 62
Bismarck-continued

Russian support secured by 66

Schnaebelé incident, on 2 I 7 territorial ambition of Prussia, on 142,143

Versailles, demands made at 68 interview with Favre at 64

Blanc 105

Blind, attitude of mass of Alsatians to Germany 200-I

official classes in Alsace-Lorraine ${ }^{1} 7^{8}$

Blumenthal 208

Bluntschli, plebiscite, on 306-7

Böcking, Sarre mines 256-7

Bodley, change of French policy, on 222-3

Franco-German conflict in Morocco, on 218

Boll, desideratum in solution of problem, on, 3

Bonnard 265

Bordeaux, National Assembly at 64

Boulanger $2 \mathrm{I} 7$

Boulangist movement $163,217-18$, 22 I

Boundaries 34

See also Frontier

Bourgeois, French national policy, on 223-4

Brandenburg, Prof. $25^{8}$

Bray, Count von 92

Briey, German demands as to 257

Bruno, Archbishop of Cologne 51

Brussels, negotiations at $73-5$

Bucer 56

Budget 45,46

Buffer State, Alsace-Lorraine as a value of 283

$$
273,-82-3,284-5
$$

Bulach, Baron de 168

Bülow, Prince von 183

French temper, on the $224^{-6}$

Campo Formio, treaty of 294

Caprivi, passport system in Alsace $16_{4}$

Cateau-Cambrésis, treaty of 53

Catholic party 190

anti-clerical campaign 190

Democrats leave the I 9 I

Censorship, imposition of 164

Chamberlain, Houston 183

Chanzy 106

Charlemagne $5^{\circ}$

Charles IV 55

Charles V 53

Charles the Bald 51

Church and State, relation between $4^{\mathrm{O}}, 4 \mathrm{I}, 247$ 


\section{Claims of Germany to Alsace- Lorraine I 2 seq. conquest i47. See Conquest economic necessity $132 \mathrm{seq}$. historical grounds I I $3 \mathrm{seq}$. difficulties in I I 7-18 early treaties i I 5 Holy Roman Empire ap- pealed to I 6 \\ Mommsen's view II 4 \\ Ranke's view I I 3 \\ Treitschke's view I I 4 - I 5 \\ language, on ground of $123 \mathrm{seq}$. difficulties involved 127 \\ military necessity $137 \mathrm{seq}$. \\ nationality, question of $127 \mathrm{seq}$. political necessity I35 seq. criticism $135-7$ \\ public right, principle of I $30-3 \mathrm{I}$ \\ racial grounds II $8 \mathrm{seq}$. difficulties involved I $2 \mathrm{O}, \mathrm{I} 2 \mathrm{I}$ names as criterion II \\ self-contradiction $12 \mathrm{I}$ \\ territorial lust I4 I seq. \\ Treaty of Frankfort, binding force of I 5 I \\ Clausewitz I 4 I}

Clemenceau 230

Climate 37

Clovis $5^{\circ}$

$\mathrm{Coal}_{42}$

See also Coal and iron resources of Germany and France $25^{8}$

Coal and iron, effect of depriving Germany of $261-2$

German declaration in 1915 $252-6$

problem of $25^{\mathrm{r}} \mathrm{seq}$.

war, in $251-2,255^{-6}$

Communication, means of 44

Concordat $4^{\circ}$

Condé 57

Configuration of surface 34,35

Conquest, claims to Alsace-Lorraine based on $\mathrm{I}_{47}$

German view as to $\mathrm{I}+3$

illegitimacy of 145

recent growth of opinion as to I 44

right of 186

treaty, as recognised by 149

Von Sybel on 91

Conrad the Red 5 I

Dallwitz von Roedern 174

Debt 45

Delbrück, reannexation to France, on $237-9$
Democrats I9I

Déroulède, quoted I66, 2 I 5

Dreyfus affair $22 \mathrm{I}-2$

Eckhart $5^{6}$

Economic position $4 \mathrm{I} \mathrm{seq.}$

Education 46, 47

Egidy 264

Emigrants, Germany, from I 33 plebiscite, in case of 3 I 5

Ems telegram 6r, 149

Entwelschung 176,199

Eucken, autonomy, on 266

Expenditure 45

Exports 44

Fabert 53

Favre, Ferrières, at 63

Frankfort, at 75

Preliminaries of Versailles, after $7 \mathrm{I}$

Versailles, interview with Bismarck at 64

Ferrières, interview between Bismarck and Favre at 63

Ferry 2 I 7

Fiore, conquest, on $\mathrm{I} 49$

Fischart I 7

Foreign labour I 33

Förster, autonomy, on 265-6

France, For various matters see

Francis III $5+$ separate heads

Francis Joseph I 4

Franco-German War 6I seq.

Frankfort, Convention of (18I9) $25^{\mathrm{S}}$

negotiations at $75^{-7}$

treaty of, $65,185,187,232$

binding force of 151,233

provisions of $77 \mathrm{seq}$.

Von Bülow on 225,226 whether abrogated by the war I 5 I, 233

Franzos 204

Franzosen-fresserei $\mathrm{I}_{1} 3$

Französling $\mathbf{1} 80$

Frederick I I 29

Frederick the Great I +2

Free Imperial towns 55

French attitude towards AlsaceLorraine $2 \mathrm{I}+\mathrm{seq}$.

disturbing currents in France since $\mathrm{I} 87 \mathrm{I} 22 \mathrm{I}-2$

Great War, after outbreak of 227 seq.

nationalities, question of 222-3

pacific policy of French democracy 2 I $9-20$

phases of French feeling 2 I4 
French attitude-continued

recent national policy 223-4

revanche ideal $2 \mathrm{I}_{4} \mathrm{seq}$.

evanescence of 2 I 6 seq., 220 seq., 224

French Revolution, Alsace at 59

fusion between France and Alsace 129

Fried, Alsace-Lorraine as cause of the war, on 29

compromise preferable to slaughter 32,280

Froelich, pan-Germanism in AlsaceLorraine $18 \mathrm{I}$

Frontier, desideratum in fixing 301

former, untenable 242

rearrangement suggested 287,289 security of $138 \mathrm{seq}$.

Fustel de Coulanges, nationality, on I 28

nationality of Alsace, on 130

Gaede, General, proclamation of 209

Gambetta 194, 21 4, 2 I 6 assumes dictatorship 63

George, Lloyd, restoration of AlsaceLorraine 231

Germany, aggressiveness of 28

For various matters see separate heads

Gladstone, annexation of Alsace-

$$
\text { Lorraine, on } 24,147^{-8}
$$

liberty, on 174

Glattbach 309

Gobat, rcpressive measures in AlsaceLorraine $166-7$

Goltz, Von der I 4 I

Gortchakoff, circular of 67

' Gottesfreunde,' the 56

Gottfried I I 7

Grafenstaden affair 165

Granville, concludes treaties ( $187 \mathrm{O}$ ) to protect Belgium 62

Great War, attitude of Alsace-Lorraine on outbreak of $2 \mathrm{O}_{7} \mathrm{seq}$.

attitude of German authorities towards Alsace-Lorraine on outbreak of 209

precautions of Germany in Alsace-Lorraine $175^{-6}$

Treaty of Frankfort not abrogated by 151,233

Grévy, 98, 104, 217

Grosjean 107

Guester, Abbé i 58

Gustavus Adolphus 57

Gutenberg 56

Hanotaux, protests in 1871,109

Thiers's efforts in negotiation 69
Hansi I 68

Harden, partition, on 285 restoration of Alsace-Lorraine $239-4^{\circ}$

Hartmann, I09

Headlam, Rhine frontier, on 298

Heligoland I 50

Helmer, Manteuffel's régime I62 mediæval Alsace 1 I 7

plebiscite, on 312

position of Alsatians in France after outbreak of the war

Hengel I 30 on $233-4$

Henry I 55

Henry $\mathrm{V}_{5}$

Hervé, progress under German rule, on 47,48

Herzberger 290

History $49 \mathrm{seq}$.

Alsace, French Revolution 59

Middle Ages 55

part of Germany till seventeenth century 56

Thirty Years War 56 union with France 60

Charlemagne 50

Germanic invasions 49

Lorraine, of 5 I seq. annexations to France 52 cession to France 54, 55 French invasion 54 Middle Ages, in 51, 52 sixteenth century 52,53

Merovingian period 50

Roman period 49

union with German Empire $5 \mathrm{I}$

Hoeffel, declaration in First Chamber 2 IO, 2 II

Hohenlohe Schillingsfurst, Prince von 162

Holdich, German characteristics 179

Rhine frontier, on 297

Holy Roman Empire I 16-17

Home Rule

See Autonomy; Nationalist movement

Hue 259

Hugo, protest against annexation in I $87 \mathrm{I} \mathrm{IO}_{4}, \mathrm{IO}_{5}$

Immargrants, attitude of 178

fusion with natives $202-3$

number of 179

plebiscite, in case of 315

younger generation, position of $24^{8}$

Imports 44 


\section{INDEX}

Independence for Alsace-Lorraine, advantages $279 \mathrm{seq}$.

bond of union between France and Germany $28 \mathrm{I}-2$

buffer State, would be a $282-3$

fusion of Germanic and Gallic elements $28 \mathrm{I}$

government, form of 277

matters for adjustment $278-9$

military service difficulty removed $28 \mathrm{I}$

neutralisation proposed 271 seq.

revanche obviated 280

Industries $4^{1}$ seq.

International law, in $18711_{4}^{8}$

International League of Peace and

Iron Liberty $274^{-7}$

See also Coal and iron

effect of depriving Germany of $26 \mathrm{I}-2$

German resources $260-6$ I

Lorraine, in 42,259

Jagow, attitude of Alsace-Lorraine

Jähns $I_{4}$ I I 75, 199

Joffre, restoration of Alsace-Lorraine 228

Jolly, suggested division of AlsaceLorraine in 1871,92

Jordan, Alsace-Lorraine against war as solution 3 I I

Alsatian names, character of I 19

Julius Cæsar 49

Katzenstein 309

Keller 98, 103, 106

Kellermann 130

$\mathrm{Kiel}$, treaty of $15^{\circ}$

Kléber 130

Koeller, régime under $167-8$

Kühlmann, Alsace-Lorraine in relation to the war, on 29 reannexation to France, on $236-7$

Labour Party 309

Lalance 3 II

Lamberty, attachment of Alsace to France 129

Landesausschuss I 59

See Territorial Delegacy

Language $3^{S}-4^{\circ}$

division on basis of $290-92$

index of feelings and desires of the people, as $2 \mathrm{O}_{4}-5$

partition, in regard to $285-6$

question of $123 \mathrm{seq}$.

reannexation, in case of $243^{-4}$
Lasson 90, I 41

conquest, on $I+3$

Launay, German coal and iron supplies, on 260

Laussedat, boundary commission $80-8 \mathrm{I}$

negotiations with Bismarck, on $76-77$

League of Free Cities 55

Lefebvre 130

Leopold 54

Liberal democratic party 190

Lichtenberger, attitude of Alsatians, on 200

autonomy, on 264

education, on 47

law in case of reannexation 244 new generation, attitude of $2 \mathrm{O}_{3}$ plebiscite, on 313

unity of Alsace, on 243

Liebknecht, protest against annexation in 1871,86

Ligue Patriotique 200, 208

'Lois d'exception' 164

Longwy, German demands as to 257

Lorraine. See heads for particular topics

cession to France 54-5

Middle Ages, in 51

sixteenth century, in 52

Lothair 50

Louis XIV, annexation of Strassburg 59

natural defences under 297

Louis the German 5 I

Lunéville, Peace of 294

Lyde, boundary readjustment, on 289

Maass, Rhenish Alpine Confedera-

Machiavelli it I tion suggested 288

Macmahon 221

Malon rog

Mandel 168

Manteuffel, régime under $159,16 I-2$, I63

Manufactures ${ }_{4} \mathrm{I}$ seq.

Marseillaise, the $60,128,168,198$

Mehemet Ali I I 3

Merlin of Douai 60

Metternich, Rhine boundary, on 294-5

Metz. See also Pays messin annexation of, Mommsen on $139-40$

Bismarck's doubts about 97

German element in 133 
Military service, introduction in Alsace-Lorraine 156

Minerals $37,42,43$

Minette 255, 256

Moltke 143

Mommsen, claims of Germany to Alsace-Lorraine, on 114 conquest, on $\mathrm{I}_{4} 6$ language, claim on ground of 123 Metz, annexation of $126,139-40$ Monod 138

Morocco 218

Munster, treaty of 57,60

Napoleon, Rhine frontier, on 295

Napoleon III 145, I47, I49 plebiscite, adoption of 304 Rhine frontier, aim as to 293

National Asscmbly, debates on cession $104 \mathrm{seq}$.

National Union, formation of 191 manifesto against the Constitution of 1911,193 programme of $19 \mathrm{I}-3$

Nationalist movement $184 \mathrm{seq}$. attitude towards France and Germany 199 seq.

autonomists and protesters distinguished $189-90$

autonomy demanded $194-7$

cfforts against 169

method adopted 189

National Union 191-3

parties in $189-92$

why began 188

Nationality, option of $\delta_{2}$ principle of $127 \mathrm{seq}$.

Naumann, German attitude towards Alsace-Lorraine 177

Near Eastern Question, distinguished from Alsace-Lorraine question 21

Nesselrode 294

Neutralisation of Alsace-Lorrainc $271 \mathrm{seq}$.

Bismarck's view $89-90$

German objections to 273-4

Treitschke's view go

Newspapers, suppression of $6_{4}$

Nimeguen, treaty of 58,153

Noisseville aftair 198

Novicow, constitution of AlsaccLorraine 172

German unity and Alsace-Lorraine $I 35$

plebiscite following autonomy 269

Oberpräsident, appointment of $15^{6}$ office abolished 159
Oncken, effects of annexation of 1871 , 110

frontier security $13^{8-9}$

Option of nationality $8 / 2$

Otto the Great 51

Painlevé, restoration of Alsace-Lorraine demanded 229,237

Palat, Alsatian demand of autonomy 219

Panama affair 221

Pangermanism 31, 180-1

Paris, Peace of $(1814) 295$

Treaty of (1 815$) 25^{8}$ (I 8 56) 66 ( 1877 ) 304

Partition of Alsace-Lorraine $285 \mathrm{seq}$. difficulties $290 \mathrm{seq}$.

language as basis $285^{-6}$

suggested in 1871,92

various forms of $286 \mathrm{seq}$.

Passport system 164

Paulsen, no question of AlsaceLorraine 25

Pays messin 126, 146 See also Metz

Petroleum 43

Pichon 140

Plebiscite, Anglo-American practice 305 appropriateness of, for AlsaceLorraine 309

autonomy followed by $269-70$

compromise necessary 316

condition of annexation, as a

demand by Alsace-Lorraine $310-$ I 1

difficulty in 315

cxamples of $3 \mathrm{O}_{2}-4$

juristic opinion on $306-7$

necessity for $250,274,302$

omission of, cases of 305

opposition to $312 \mathrm{seq}$. grounds of $30 \mathrm{~S}$ validity of 314 organisation of 317 persons who should vote 317 support of, grounds of 307 'Treitschke's view 90, 91-2

Poehlmann 190

Poincaré (President), reannexation 228

Population 37,38

characteristics of $3 \mathrm{~S}$

Postal service 45

Potash 43

Pouquet 187

Pouyer-Quertier 75 


\section{INDEX}

Prague, treaty of 305

Preiss 195

repressive measures in AlsaceLorraine 167

Problem of Alsace-Lorraine is seq. aspects of 24

French view as to 26

German denial of 25

Great War, as cause of 27

Near Eastern Question distinguished from 2

origin of $2 \mathrm{I}$

solution of $30 \mathrm{seq}$.

See Solution of problem

solutions suggested $235 \mathrm{seq}$.

See Solutions suggested

third States concerned in 22

Public right $130-31$

Public works 45

Pyat 109

Quinet, cession of Alsace-Lorraine in 1871,105

Raess, Mgr. 186

Ranc 109

Ranke, historical claims of Germany I I 3,139

Rapp 130

Ratisbon, treaty of $5^{8}$

Reannexation to France, coal and iron problem 25I seq.

commercial system 246

difficulties involved $240 \mathrm{seq}$.

educational system $247^{-8}$

fiscal legislation 246

German attitude $236 \mathrm{seq}$.

Great War, attitude of AlsaceLorraine before 197 seq.

industrial organisation 245

interregnum suggested 249

language question 243

legal system $244-5$

mixed population 248

modes of effecting 235

nationalist movement as affecting 249

plebiscite following 235-6

political grouping 243

religious question 4O, 4I, 247

Reason of State I 43

Referendum. See Plebiscite

Régime in Alsace-Lorraine, Bulach (Baron de), under I68-9

censorship I 64

Council of State established I60

Dallwitz von Roedern, under 74

dictatorship (1 $87 \mathrm{I}-3$ ) I 56

economic pressure 165
Régime in Alsace-Lorraine-continued educational measures 165-6

'exceptional' laws 164

exclusion of natives from public functions ${ }^{6} 6_{5}$

failure, reasons for $177 \mathrm{seq}$.

germanisation not effected 176 seq.

Government Bill (1910) I69

Great War, precautions on outbreak of $175^{-6}$

Hohenlohe Schillingsfurst, under 162

imperial constitution applied (I 874 ) I 57

Koeller, under $167-8$

language, conflict as to 166

legislation, methods of $160-61$

Manteuffel, under $16 I-2$

military occupation (I870-I) I 55

nationalist movement, efforts against 160

See also Autonomy; Nationalist movement

new constitution (I9II) I 70 seq.

newspapers suppressed 164

official classes 167,178

passport system 164

progress in many respects 47

repressive measures $163 \mathrm{seq}$.

societies dissolved 164

Statthalter appointed 159

status from February i 87 I to June I 87 I 155

suspicion and espionage 165

Territorial Delegacy i 59-6i

See Territorial Delegacy

Religion 40

Religious question $40,41,247$

Renan, racial claims of Germany 12 I

Revanche 21, 31, 32, 33, 176, 214 seq., 239,265

See also French attitude towards Alsace-Lorraine

Revanchegelüst I 52

Reyle 206

Rhine as a boundary $293 \mathrm{seq}$. difficulties $297^{-S}$

Ribot, restoration of Alsace-Lorraine $229-30$

Ricklin 209, 211

Rochefort IO9 $_{9}$

Rudolf III 55

Russia, entente with France (I $89 \mathrm{I}) 2$ I 8 Ryswick, treaty of 54,59, I 53

Saint-Aignan 294

St. Odilia $5^{\circ}$

Saint-Vallier I Io 
Salisbury, Lord, plebiscite, on 305

Saverne affair 175,198

Scheidemann, autonomy, on 267

Schmettau I 29

Schnaebelé incident 163,2 I $7^{-1} 8$

Schönaich Carolath 257

Schongauer $5^{6}$

Schücking, German agressiveness, on 28

Schumacher, German need of coal

Schwob i 80 and iron $25^{6-7}$

Sembat, attitude of Alsace-Lorraine 201, 203

autonomy, refusal of 172

French feeling after annexation in 1871 , on $215^{-16}$

Seward, plebiscite, on 305

Sirhanun I 30

Socialists, Alsace-Lorraine, in 190

France, in 230

self-determination, on 309

Germany, in, annexation proposals $25^{8}$

autonomy, on $26_{7}$

Conference at Würzburg (1917) 286

self-determination, on 309

Societies, dissolution of 164

Solution of problem, desiderata in $30,31,33$

difficulties in 31

justice the fundamental point in 33

Solutions suggested, arbitration of the Pope 290

autonomy within the German Empire $263 \mathrm{seq}$.

See Autonomy for AlsaceLorraine

Confederation, to form part of a new 288

division among German States 287

frontier rearrangement 287,289 independence for Alsace-Lorraine $27 \mathrm{I}$ seq.

See Independence for AlsaccLorraine

partition between France and Germany $285 \mathrm{seq}$.

Sec Partition of Alsace-Lorraine

pays messin to France and rest r.eutralised 288

plebiscite in $302 \mathrm{seq}$.

See Plebiscite

reamnexation to France $235 \mathrm{seq}$.
Solutions suggested-continued

See Reannexation to Franee

Rhine as boundary $293 \mathrm{seq}$.

union of Alsace with Baden 286

Spiess 190

Stanislaus Leszczynski 54

Statthalter 159

Stowell, conquest, on I49-50

Straits Convention ( 1856 ) 66

Strassburg, German element in 133 seventeenth century, in $5^{8}$ University of 47 germanisation of $x_{5}$

Streams in Alsace-Lorraine 37

Sturm von Sturmeck 56

Sybel, conquest, on $9^{1}$

Tachard, Alsace-Lorraine as a buffer State 272

Talleyrand, Prussian ambition, on $\mathrm{I}_{42}$

Tauler $5^{6}$

Telegraph service 45

Telephone service 45

Territorial Delegacy, composition of I 59, I60

establishment of 159

functions enlarged 159

legislation, part in $160-6 I$

political alliances in 189

rupture with ministry 168

Territory, German lust for $\mathrm{I}_{4}$ I seq.

Teutsch 184

Thibaudin 217

Thiers, head of the executive $64, \mathrm{rO}_{3}$ interview with Bismarck at Versailles 68

interview with German Emperor and Crown Prince 69 mission to European Powers 63 Preliminaries of Versailles sub. mitted to Assembly $\mathrm{IO}_{4}$

Thirty Years War $5^{6}$

Three Bishoprics, the $5^{\mathrm{I}}$

Tilsit, Peace of $3 \mathrm{O}_{5}$

Tirard 106

Transport, means of 44

Treaties, binding force of $\mathrm{x}_{5} \mathrm{I}-3$

future international co-operation and 283-4

Treitschke, autonomy, on 94

claims of Germany to AlsaceLorraine, on I I 4 conquest, on 146

military necessity of annexation, on $137^{-8}$

military service in Alsace, on I $56-7$

natural deficiencies of Germany; on 134 
Treitschke-continued

neutralisation, on 90,273

partition, on 92-3

plebiscite, on $90,91-2$

political necessity of annexation I 35

pretensions of 122

Trouée de Belfort 37

Turenne 57

'Ubi societas ibi ius ' 271

Utrecht, treaty of 153

Vaucouleurs, treaty of I I 5

Verdun, treaty of $5^{\circ}$, I I 5

Vereeniging, Peace of 244

Versailles, Preliminaries of 65,70 debate on $\mathrm{IO}_{4} \mathrm{seq}$. provisions of $7 \mathrm{I}-3$ vote on 107

Vienna Congress 142

Vienna, treaty of (1755) 54 (I 815 ) 153 (I86.7) 305

Vincennes, treaty of $5 \cdot t$

Viviani, reannexation of AlsaceLorraine 227,228

Vosges, as frontier 298

Wagner, plebiscite, on 92

Wedel, Count von I 69

Wedelpissdorf, Alsatian demand for autonomy 173

Weill, Alsatian desertions from German army 209 autonomy demanded in Reichstag 194

plebiscite, on 313
Welsche 180

Welschinger, protest in $1871,103,108$

Wendel 259

Westarp $25^{8}$

Westphalia, treaty of 57, I 53

Wetterlé, autonomy as a steppingstone, on 197, 208

Constitution of I 9II, I 7 I-2

Dallwitz von Roedern's régime 174

declarations of the two Chambers in 1917 , on $210-11$

difficulties of reannexation 249

industrial organisation in case of reannexation 245

plebiscite, on 3 I 2

reassimilation to France, on $24 \mathrm{I}-2$

religious question, on 247

William I I 37,237 reason for annexation, on $\mathrm{I}_{4} \mathrm{O}$

William II I 75, 2 I 8

Wilson (President), 'reconsideration' of Alsace-Lorraine question 232

self-determination of nations 3 IO

Wine, manufacture of 43

Winterer, Abbé ${ }_{1}{ }^{\mathrm{S}}$

Wittich $2 \mathrm{O}_{4}$

'Young Alsace' 2 I9 See Nationalist movement

Zabern. See Saverne

Zeppelin 176,198

Zislin 168

Zollverein $27^{8}$ 
PRINTED IN GREAT BRITAL

BY HAZFLL, WATSON AND VINEY, LD., LONION AND AYLESBERY. 



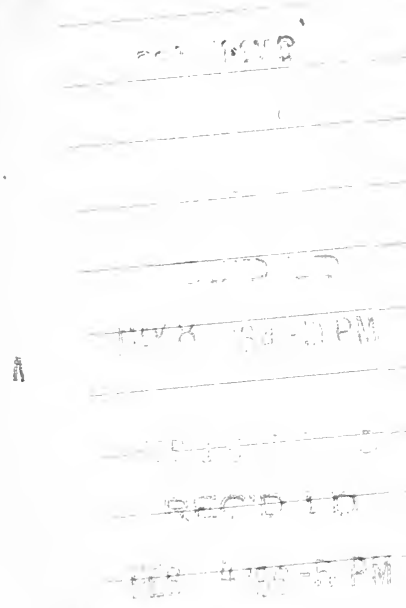

43) 2006

WNERERPABY LOAE

AP $1-40 A$

HA 
THE UNIVERSITY OF CALIFORNIA LIBRARY 
